WSRC-RP $--90-424-2$

DE93 006329

\title{
Radioiodine in the Savannah River Site Environment $(U)$
}

\author{
M. V. Kantelo \\ L. R. Baver \\ W. L. Marter \\ C. E. Murphy, Jr. \\ C. C. Zeigler \\ Westinghouse Savanneh River Company \\ Sevannah River Site \\ Aiken, SC 29808
}

Approved by: $\quad$ A. L. Boni, Manager

Environmental Technology Section

Savannah River Laboratory

Prepared for the U. S. Department of Energy under contract No. DE-AC09-89SR18035 
This page intentionally lent blank. 


\section{Contents}

Glossary i

Preface

Executive Summary

Chapter 1.

Radioiodine in the Global Environment 1-2

Radioiodine in Regional Environments 1-3

Radioiodine ir the SRS Environment 1-4

References for Chapter $1 \quad$ 1-6

Chapter 2.

Origin of Radioiodine at SRS 2-3

Irradiation in Production Reactors 2-3

Other Sources Due to SRS Operations 2-4

SRS Test Reactors 2-4

Spontaneous Fission 2-4

Neutron Activation Analysis 2-5

Materials Originating Offsite $\quad 2-5$

Disposition of Radioiodine at SRS 2-6

Radioiodine in Fuel and Targets Irradiated in Production Reactors 2-6

Radioiodine in Certain Fuels Irradiated Offaite 2-7

Radioiodine in Fuel and Targets Irradiated in Test Reactors 2-7

Radioiodine from Spontaneous Fission 2-7 
Neutron Activation Analysis Samples 2-7

Commercially Purchased Radioiodine 2-7

Global Fallout Radioiodine $\quad$ 2-7

References for Chapter $2 \quad 2-7$

Chapter 3.

Reactor Facilities 3-3

Facility Operations 3-3

Pathways for Release 3-3

Emission Control 3-4

Release Monitoring 3-5

History of Measured Releases 3-5

C Reactor 3-6

K Reactor 3-6

L Reactor 3-7

P Reactor 3-8

R Reactor 3-8

Summany of Reactor Releases 3-9

Separations and Liquid Waste Facilities 3-10

Facility Operations 3-10

Pathways for Release 3-10

Emission Control 3-11

Release Monitoring 3-12

History of Measured Releases 3-13

F-Area Aqueous Releases 3-13

F-Area Atmospheric Releases 3-13

H-Area Aqueous Releases 3-14

H-Area Atmospheric Releases 3-14

Effluent Treatment Facility 3-15

Waste Tank Farms 3-15

Summary of Separations and Liquid Waste Facilities 3-16 
Solid Waste Disposal Facility 3-17

Savannah River Laboratory 3-17

Savannah River Laboratory 3-17

Other Facilities 3-18

Summary of Measured Releases from SRS 3-19

References for Chapter $3 \quad 3-21$

Chapter 4.

Atmospheric Transport 4-2

Air 4-3

Deposition in Rain 4-7

Terrestrial Deposition 4-8

Vegetation 4-11

Food 4-12

Summary of Atmospheric Transport 4-15

Groundwater Transport 4-16

F-Area Seepage Basin System 4-16

H-Area Seepage Basin System 4-19

Solid Waste Disposal Facility $4-20$

Surface Water Transport 4-21

Surface Waters at SRS 4-21

Savannah River 4-24

Downriver Water Treatment Plants 4-27

Savannah River Estuary and Atlantic Coastal Waters 4-27 
Summary of Aqueous Transport 4-28

Concentrations in Animals 4-29

References for Chapter 4-31

\section{Chapter 5.}

Relationship of Dose to Risk and Health Effects 5-2

lonizing Radiation 5-2

Cancer Risk Estimates 5-2

Radioiodine Exposure ard Dose to Humans 5-3

Distribution and Retention of lodine in the Human Body 5-3

Radiation Carcinogenesis of the Thyroid Gland (BEIR, 1990) 5-3

lodine Dosimetry 5-4

Models of Radioiodine Transport and Dose 5-7

Calculational Models 5-7

Modeling Atmospheric Dispersion of Radioactive Releases 5-7

Modeling Doses From Liquid Releases 5-9

Verification of Models Using Measurement Data 5-16

Atmospheric Releases 5-16

Liquid Releases 5-16

Impact of SRS Radioiodine Releases on the Offsite Population 5-16

Doses from Atmospheric Releases 5-16

Routine Releases 5-16

Acute ${ }^{131}$ I Release Incident of $1961 \quad 5-17$

Doses from Liquid Releases 5-18

Comparisons of Radioiodine Concentrations and Doses with Applicable Regulations 5-22 
Concentrations and Doses in Air 5-22

Concentrations in Groundwater $\quad \mathbf{5 - 2 2}$

Concentrations and Doses in Offsite Surface and Potable Waters 5-22

Summary of Dosimetric Impacts 5-24

References for Chapter $5 \quad$ 5-25

Appendix A-Physical, Chemical and Biological Properties of lodine $A-1$

Physical Properties A-1

Chemical and Biological Properties A-1

Properties in Nuclear Reactor Accidents A-2

References for Appendix A A-3

Appendix B-Environmental Sampiing and Analysis B-1

Routine Site Operating Conditions B-1

Air B-1

Rain B-1

Milk B-2

Groundwater B-2

Surface Water B-2

Enluent Outfall from Process Areas B-3

Site Streams B-3

Savamnah River B-3

Other Environmental Media B-3

Emergency Response Conditions B-3

Weather Information and Display System B-j

Radiological Assistance Program Laboratory B-3

Tracking Radioactive Atmospheric Contaminants Laboratcry B-4

Field Sample Collection Teams B-4

Bibliography i 
This page intentionally left blank.

TOC-6 


\section{Glossary}

abeorbed doce - The energy deposited per unit mass of matter when ionizing radiation interacts with matter. Conventionally expresed in units of rad. In International System (SI) units absorbed dose is expreseed in units of gray (Gy), where $1 \mathrm{~Gy}$ equals $100 \mathrm{rad}$.

activation - Soe nuclear resction.

activity - See radiosctive docay.

alpha particle decay - See radionctive docay.

anion - A negatively charged ion that is produced when a molecule diesolves in water and produces two ions of opposite charge. For example, iodide is a negatively charged anion of iodine. See cation.

aquifer - A saturated, permeable geologic formation in which large quantities of water move as a result of matural hydreulic gradienta.

atom - The smallest divisible unit of matter that atill retains characterietics of an element. An atom consists of a center core (the nucleus) and a surrounding electron cloud. The nucleus consists of neutrons and protons. The number of protons in an atom determine which element the atom is.

atom percent - The number of atoms of a specific irotope relative to the total number of atoms of the element, expressed as a percentage.

beta particle decay - See rediosctive docay.

beta-gamma activity - A term for the type of redioactivity that is detectsble widh a GeigerMueller detector or other detector for energetic bets particles and gamma raya. The detoctor does not distinguish individual radionuclides.

biological half-ime - The time required for a biological system to eliminate one half of a given number of atoms of a specific isotope solely by the processes of elimination.

Cation - A positively charged ion that is produced when a molecule dissolves in water and produces two ions of opposite charge. See anion.

CEDE - Committed Effective Dose Equivalent

cladding - Material that encapeulates nuclear fuel and targets. It serves as a container for the nuclear material and barrier between the moderator and the irrediated fuel and targets which contain fission and activation products.

collective dose - The effective or tiseue-specific dose equivalents received by members of an exposed population. See also pereon-rem.

committed dose equivalent - The dose equivaleat delivered to a tissue or organ over a so-year period following intake. 
committed effective dose equivalent - The committed dose equivalents to various tiseves in the body, ach multipliod by the appropriate weighting factor, and aummed.

concesteation - The quantity of a material per unit of volume or mass that the material is a constituent of. In this report, concentration typically refers to the quantity of an ieotope of iodine per liter of liquid, per cubic meter of air, or per gram of a solid.

cooling period - The time interval that irradiated materials are stored before being reprocessed. During this time, short-lived rediojodine docays to inconsequential sctivity levels.

curie - A unit of radionctivity. Abbreviated a Ci. One curie is $3.7 \times 10^{10}$ decays per second. Annual releanes of redioiodine are expreased in units of curies. Bnvironmental levels of redioiodine are expreased in units of $\mathrm{PC}$, where $1 \times 10^{12} \mathrm{pCi}$ equal $1 \mathrm{C}$. In International Syatem (SI) units, ndionctivity is expreseded in units of bequerel, where 1 bequerel is 1 decay per second (equal to $27 \mathrm{pC})$.

DCG - Derived Concentration Guide

decay - The process of a redioactive transformation

deionizer - See ion exchange.

deposition velocity - An empirical value that relates the conceatration of a material is air to the flux density of a material at the ground or plant aurfaces.

Derived Concentration Guide - The concentration of a radionuclide in air that wculd reault in an effective dose equivaleat of 100 mrem under conditions of continuoue exposure to wech air for one year. Also, the concentration of a radionuclide in water that would result in an effoctive dose equivalent of 100 mrem uader conditions of continuous exposure to such water for one year.

detection l'nit - See definition $\$ 1$ for sensitivity.

dose - See abeorbed dose.

dose commitment - The radiation dose received over a specified time period that the radiosetivity persists in the body.

dose equivalent - The product of the abeorbed dose and a quality factor which is dependent on the relative biological effectiveness of the ionizing radiation. Typically expreaced in units of rem or millirem (1 mrem $=0.001 \mathrm{rem}$ ). In International Syetem (SI) units, doce equivalent is expreseed in units of sievert, where 1 sievert is 100 rem.

dose factor - A conversion factor wivin, es applied to this report, indicates the 50-your committed doee equivalent or 50 -year committed effective dose equivalent delivered per unit intake of radiosctivity. Conventional units are mrem per pCi of intake.

EDE - Effective Dose Equivalent

effective dose equivalent - The summation of the dose equivalents received by specific tibsues of the body when weighted with timure-epecific factors. 
effective half-life - The apparent half-life that results when both biological elimination proccares and radioective docay occur simultaneously. Soe balf- Left.

equilibrium - Soe radionctive equilibrium

fission - See nuclear fission

fission product - Any auclide, stable or radionctive, resulting from the process of nuclear fission. The definition includes the primary fiesion fragments formed at the instant of fission, as well as the daughter products from docay of the primary fission fragments.

gamma ray - A phuson that is emitted from a nucleus when the nucleus undergoes a transition from a higher energy level to a lower energy level. In this report, this energy level trancition typically is asocinted with radionctive decay of a nuclide. Because the transition is between specific enersy levels, the gamma ray has a specific energy which is characteristic of the nuclide undergoing docay. Typical energies of gamma rays of intereat range from tens of kiloelectron volts to thousands of kiloelectron volts.

gamma-emitting radionuclide - A nuclide that emits a gamma ray during the process of $n$ dionctive decay.

samma spectrometry - A tochnique to identify gammemitting radionuclides by measuring the characteristic gamma nays emitted during their decay. When a gamma ray interacts with a detector for gamms spectrometry, it can deposit its full energy in the detector. This eaergy is converted into an electronic signal which is proportional to the gamma energy. Thue, gamma nys of different energies can be corted into a spectrum. Interpretation of the spectrum results in identification of gamma-emitting radionuclides. Typical detectors include sodium iodide and germanium. These can be calibrated for detection efficiency as a function of gamma energy and sample geometry. The efficiency is used to quantify the sctivity of radionuclides.

GASPAR - A computer code developed for the Nuclear Regulatory Commiscion to evaluate doses from atmospheric routine releases of radionuclides.

grab sample - An instantaneous collection of an environmental sample.

halfflife - The time interval required to halve the number of atoms of a specific irotope that are present in a given system. Half-life pertains to two proceseses in this report. Radioactive decay results in a radiological half-life. Elimination from biological systems reaults in a biological balf-life. When both processes occur simultaneouly, an effective half-life results. Soe radiological half-life, biological half-time, and effective half-life.

half-time - See half-life.

heavy water - Water in which deuterium has been subetituted for the normal hydrogen atoms of the water molecule. Deuterium is a rare natural stable isotope of hydrogen. The nucleus of a deuterium atom contains one neutron wheress a normal hydrogen atom has none.

HEPA filter - High Efficiency Particulate Air filter. Atype of filter that traps particles from air that is passed through the filter. It traps greater than $99.97 \%$ of particles with a diameter of $3 \times 10^{-7}$ meters or larger.

internal dose factor - See dose factor. 
ion - An atom, a group of atorias, or a molecule that has either loat or gaingd one or more electrons.

ion exchange - The process of removing anions and/or cations from a solution by passing the solution through ion exchange material, also known as a deionizer.

ionizing radiation - Radiation capable of removing electrons from atoms as the radiation passes through matter.

uradiation - The process of exposure of matter to radiation, which can be either ionizing radiation or seutrons.

isotope - A nuclide that belongs to a specific element. Each different isotope of an element has the same number of protons but a different number of neutrons. See nuclide.

botopically enriched - When the abundance of an isotope in a sample of an element is greater than its abundance in nature.

keV - An abbreviation for kiloelectron volts.

lailo electron volt - A unit for the energy of the radiation cmitted in radionctive docany.

LADTAP II - A comput:" code doveloped for the Nuclear Regulatory Commisuion to evaluate doese from liquid nes of ndionuclides.

leach - The procesas by with water interects with an insoluble material to remove rhose constituents that have some degree of water-eolubility.

low enersy photon spectrometry - A type of gamma spectometry that is used to measure photons having energies leas than $100 \mathrm{keV}$. A special detector is required to detect such low energiea. Typically, $x$-rnys and low energy gamma rays are detected by this technique.

MAXICASP - An SRS-modified verion of the computer codes XOQDOQ and GASPAR. MAXIGASP calculates doeces to offinite individuals from routine atmospheric releases of radionuclides. For doses to individuals, MAXIGASP does not use the population dose calculational routines of GASPAR.

metastable state - An energy state that is greater than the ground state of the nucleus of an atom and has a measurable half-life. See nuclide.

moderator - A material whose purpose is to reduce the kinetic energy (slow the speed) of the energetic neutrons emitted in the fiesion process. In SRS reactors, the moderator is heavy water.

millirem - A unit of dose equivalent which is one-thousandth of a rem.

molecular sieve - A hydrated aluminum and calcium or sodium silcate with an open molecular atructure that allows trapping of cerain vapors. See silver zeolite.

mrem - Abbreviation for millirem.

neoplasm - Any new or abnormal growth such as a tumor, whether malignant or benign. 
neutron activation - In this report, a type of neclear resction in which a trget nucleus interacts with a neutron to either capture the neutron (referrod to as neutron capture) or emit two neutrons (roferred to as $(n, 20)$ resction).

neutron capture - See nelimn sctivation.

nuclear fiacion - The process of eplitting a heavy nucleus generally into two lighter nuclei plus severil neutrons. This process chi occur naturally as a type of redioactive decay (epontaneous fiscion) or ss neutron-induced fiscion. The two lighter nuciei, called fiacion products, are not unique in the firaion process. Intead there is a distribution of fission prochucts which include inotopes of iodine.

muclear reaction - Nuclear reactions described in this report are limited to the internction of a turget nucleas with a neutron. Example reactions are neutron-induced fiecion, neutron capture, sod $(n, 2 n)$. See nuclear fission and neutron sctivation.

nuclewe - The center part of an atom. It is composed of at least one proton and zero or more neutrons.

nuclide - An atom chancterized by a specific number of protons and seutrons and by its energy state. A nuclide is either stable or unstable. An unitable nuclide is radiosctive and is known as a radionuclide, for example ${ }^{13 \%}$. The nucleus of a given atom may aleo have the property that it can exist for come length of time in an energy atate greater than the ground atate. Such an excited energy statc is known as a metastable atate. The nuclide deaignation for an atom in the metantable state includes the label " $\mathrm{m}$ " for metnatable, for example ${ }^{130} \mathrm{P}$.

overhead - The vapor and condenate generated in the operation of an evaporator.

pCI - Abbreviation for picocurie. A unit of redionctivity. One pCi corresponds to 2.22 docays per minute. See curie; $1 \times 10^{12}$ pCi equal 1 curie.

perched water - Water whose downward percolation is i' derruptod by low-permenbility soil.

pereon-rem - Unit of collective done to a population group. For example, a doec of $0.0002 \mathrm{rem}$ to each of 10,000 individuals reoults in a collective doce of 2 pernon-rem.

photon - Electromagnetic radiation that for purposes of this report conasists of either a gamma ny or en x-ray.

POPGASP - An SRS-modified verrion of the computer codes XOQDOQ and GASPAR. POPGASP calculates doces to offrite populations from routine atmospheric releases of radionuclides.

population dose - Another term for colloctive doce; see aleo person-rem.

rad - Unit of abeorbed dose; see aleo sbecrbed dose.

radioactive decay - The process en unatable nucleus undergoes to schieve greater stability. Decay procences included in this report are alphn particle emiscion, beta particle emiscion, isomeric transition, and apontancous fincion. In alpha particle docay, an unatable nucleus emits a particle conaisting of two neutrons and two protons. Gamma rays and $x$-rays may be ancoci-

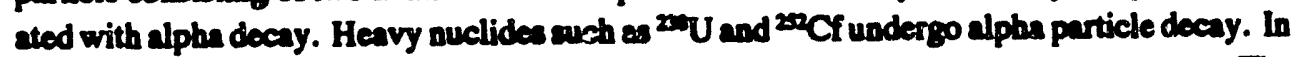
beta particle decay, an unstable nucleas transforms a neutron into a protoa and electron. The 
electroa is ejected from the nuclews (a beta paricle is an electron originuting in the nuclews). Gamma nays and x-rays may be aseociated wi h beta decay. A metartable atate may decay by emitting a beta particle or by isomeric trancition to the ground state. Gamma and $x$-rays may be emittad in the inomeric tranition procesl. For a description of the epontaneous fiasion decay mode, see nuclear fiecion.

The chnin of melides involved in rediosctive decay are referred to in terms of genetic relationships. The starting nuclide is called the parent. The nuclide the parent decays to is called the daughter, etc.

radioactive equillbrium - A steady-atute condition in radioactive ibcay when the daughter nuclide is aleo radioactive and has a half-life shorter than that of the f areat. Following chemical separation of pareat and daughter nuclides, atoms of the daughte: prodvesed by subeoquext decay of the parent will scoumulate ferter than they docay in the purified pareat until equilibrium is eatablished. For prectical purpowea, equilibrium is attained atter a time interval equal to about 7 balf-lives of the daughter. In this steady atrie condition, the daughter decays as a rate equal to its rate of formation; its rate of formation depends on the half-life of the parent. Therefore, in equilibrium, the apparent thalf iffe of the daughter is equal to tha bolf-life of the pareat.

The equilibrium relationship is demonatrated in Tuble 2-1. One of the products of irradiation in SRS reactors is 12 with a half life of 2.3 hours. During the cooling period, it is in equilibrium with its ${ }^{10}$ Te pareat and decays with the ${ }^{20}$ Te balf-life of 3.3 daye.

radiobadine - A collective term for radioective isolopes of the element iodine.

radiological halfilfe - The time required for one half of a given sumber of atome of a specific isotope to undergo ndioactive decay.

radionuclide - A rationctive nuelide.

rem - Unit of dose equivalent. The typical unit is millirem, or ose cse-thousandth of a rem.

seepage basin - An excavated area that receives wastewater. It is deaigned to prevent overflow unless into another seepage basin. Thus water cecapes fron these basins by evaporation or mignation through the soil. Soluble materials migrate with the water. The ion exchange properties of the soil retard the migration of various soluble materials to differeat degrees.

sencitivity - 1. The sualleat quantity of a material that can be reliably measured in the analysis of a sample. 2. The degree to which a particular tisene is affected by ionizing radiation.

SHIELD - An SRL-developed computer code that calculates the inventory of fiesion products for given resctor operating condition. The calculation of the inventories for over 800 fiscion product scoounts for the converion of fimsion products by neutron capture reactions as the fiscion products sccumulate in the material being imadiated. Documentation of SHIELD is found in Fincth, D.R., 1987, "The SHIELD Syatem Uner's Menual”, DPSTM-87-700-2, E.L. du Poot de Nemours and Company, Ire, Aiken, SC.

SHIELD was ued to calculate redioiodine inventories for Table 2-1. Miesing from Table 2-1 is $12 \mathrm{I}$, which is priccipally produced by the $(\mathrm{n}, 2 \mathrm{2n})$ nuclear reaction on the atable isotope 211 as this fision product socumulates (the SHIIEL calculation does not include the $(n, 2 n)$ nuclear reaction). However, the setivity of ${ }^{2 m}$ is expectod to be soveral orders of magnitude leas than the sctivity of ${ }^{2} \mathrm{H}$, which is a minor composent. 


\section{Figures}

Figure 1-1. Location of SRS in the southeastem United States

Figare 1-2. Relative contributions from various sources to the total radiation dose (225,200 person-rem) for the population in the vicinity of SRS in 1989

Figure 2-1. SRS facilitic with the potential to release radioiodine

Figure 3-1. Proximity of site atreams to SRS facilities that had the potential to release radioiodine

Drgare 3-2. Mearured annual aqueous releases of ${ }^{131}$ I from $C$ Reactor

Digare 3-3. Meanured ansual atmoepheric releases of ${ }^{131}$ I from C Resctor

Figure 3-4 Measured annual aqueous releases of ${ }^{131}$ I from $K$ Reactor

Figure 3-5. Measured annual atmoepheric releases of ${ }^{231} \mathrm{I}$ from $\mathrm{K}$ Resctor

Figare 3-6. Mesured annual aquecus releases of ${ }^{111}$ from $L$ Reactor

Figare 3-7. Measured annual atmoepheric releases of ${ }^{211}$ from $L$ Reactor

Figare 3-s. Measured annual aqueous releases of ${ }^{231} 1$ from $P$ Reactor

Figure 3-9. Meanured annual atmoupheric releases of ${ }^{131}$ I from P Reactor

Digure 3-10. Measured annual aqueous releases of ${ }^{211}$ I from R Reactor into the Par Pond systern

Digure 3-11. Combined mansured annual aqueous releases from reactors

Figare 3-12. Combined measured annual atmospheric releases from resctors

Pigare 3-13. Measured annual aqueous releases of ${ }^{131}$ I to F-Area seepage basins

Digure 3-14. Measured annual atmospheric releases of ${ }^{131}$ from F Area

Figare 3-15. Measured annual aqueous releases of ${ }^{131}$ I to $\mathrm{H}$-Area seepage basins

Figure 3-16. Measured annual atmoupheric releases of ${ }^{131}$ I from H Area

Figure 3-17. Combined annual atmoepheric releases of ${ }^{221}$ from separations areas

Frgure 3-18. Combined annual releases of radioiodine from separations areas

Figure 3-19. Measured annual atmoepheric releases of radioiodine from SRL

Figure 3-20. Combined annual aqueous releases of ${ }^{131}$ from SRS

Figure 3-21. Combined annual atmoepheric releases of radioiodine from SRS

Figure 4-1. The cocurrence of nuclear weapons teats in the atmoephere from 1954 through 1989

Figure 42. Locations of PHS network sampling stations in the southeast

Digure 43. Veriation in annual average concentrations of ${ }^{191}$ in air with diatance from the center of the chemical separations areas at SRS for two representative years 
Degure 4h Example of SRS and global fallout components of hypothetical ${ }^{131}$ I concentrations beyond $1 \mathrm{~km}$ from the expartion facilition

Doure 4-5. Annual average concentrations of ${ }^{131} I$ in air at the $20 \mathrm{~km}$ radius from 1955 through 1989 compared to annual average coscentrations of particulate beta rediosctivity in southeastern air from 1956 through 1970

Figure 46. Measured and calculated concentrations of ${ }^{131} I$ in air ( $\left.\mathrm{PCi} / \mathrm{m}^{3}\right)$ near SRS for May 30 through June 7 during the 1961 relane incident at SRS

Fegure 47. Measured air concentrations of ${ }^{131}$ I near SRS following the 1986 Chemobyl reactor accident

Figure 4-8. Annual average depocition of ${ }^{211} \mathrm{I}$ in rain at the $20 \mathrm{~km}$ radius from 1955 through 1989 compared to annual average deposition of beta radioactivity in southenetem nin (1960 through 1970 and intermittently to 1986) and annual average concentrations of particulate beta radioactivity in coutheastern air (1956 through 1970)

Figare 49. Variation in the cumulative terrestrial deposition of ${ }^{12}$ I with diatance from the center of the chemical separations facilitiea, as of 1978-1979

Figure 410. Contours of the cumulative terreatrial deposition of ${ }^{127}\left(\mathrm{PCi} / \mathrm{m}^{2}\right)$ surrounding SRS, as of 1978-1979

Flgure 4-11. Annual average concentrations of ${ }^{131} \mathrm{I}$ in vegetation at the $20 \mathrm{~km}$ radius from 1955 through 1989 compered to concentrations of particulate beta redionctivity in southenetern air from 1956 through 1970

Figure 412. Measured concentrations of ${ }^{131}$ in Bermuda grass (pCi/g) vear SRS on June 5 following the 1961 release incident

Figure 4-13. Comparison of annual average concentrations of ${ }^{131}$ I in milk near SRS (1957-1989) and in the southeast (1958-1970 and intermittently to 1981)

Figare 4-14. Measured concentrations of ${ }^{211}$ in millk (pCi/L) near SRS for June 5-7 during the 1961 release incident at SRS

Proure 415. Locations of whete sites near the center of SRS

Fagure 4-16. Locations of monitoring wells selected for analysis of radioiodine in groundwater near F-Area seepage basins

Figure 417. Hydrogeologic profile along a atraight line connecting the F-Area seepage basins and B Area (SRL is offset from the line; also, see Figure 3-1)

Figure 418. Correlation of ${ }^{20 I}$ and tritium concentrations in the groundwater near the F-Area scepage basins

Figure 419. Locations of monitoring wells selocted for analysis of radioiodine in groundwater near H-Area soepage basins

Figure 420. Correlation of 21 I and tritium concentrations in the groundwater near the H-Area seepage besins

Figure 421. Locations of monitoring wells selectod for analysia of radioiodine in groundwater near SWDF

Figure 4-22. Annual average concentrations of ${ }^{131}$ in SRS atreams from 1960 through 1989

Figure 423. Concentrations of 21 (PCi/L) in SRS streams and the Savannah River swamp in 1978

Figure 4-24. Concentrations of ${ }^{12} \mathrm{I}(\mathrm{pCV} / \mathrm{g})$ in sediments from SRS streams and the Savannsh River swamp in the mid 1980s

Figare 4-25. Measurod and calculated river concentrations of ${ }^{131}$ I due to SRS operations from 1957 through 1989 (Savanah River at Highway 301 Bridge downriver fr um SRS)

Fogure 426. Comparison of 19 copcentrations in the Savannah River upriver and dowariver from SRS measured intermittently from $1970-1981$ 
Figure 5-1. Dose-reaponse relationahip for tochartic effocts

Figure 5-2. Simplified pathways to humans from radioactive materials released to the atmoephere

Figure 5-3. Simplified pathways to humans from radioactive materiais released to surface or ground waters

Figure 5-4 Comparison of predicted and measured tritium concentrations in air at the site perimeter ( \pm 2 standard doviations at the 95 percent confidence level)

Figare R-1. Air monitoring locations within $40 \mathrm{~km}$ of SRS

Fegare B-2. Milk monitoring locations within $40 \mathrm{~km}$ of SRS

Fore B-3. Surface water sampling locations onsite and offsite 


$$
\longrightarrow
$$

iv

งamolum 
short-cooled - Irradiated inaterial that hes not been allowed to cool for time sufficient to roduce the content of short-lived radioiodine to inconsequential levels.

silver zeoltte - A zeolite is a hydrated aluminum and calcium or sodium silcate with an open molecular atructure that allows trapping of certain vapors. Silver-eubetituted zeolite is particularly efficient for trapping of iodine. See molecular sieve.

spontaneous fiscion - Set nuclear fiscion and radionctive docay.

stable hotope - A nonradioective irotope.

supernate - Liquid sbove a precipitate or sodiment.

eurface mixing layer - A layer of the atmoephere characterized by a temperature inversion that inhibits further vertical mixing of rolenses in the atmosphere; mixing then progreases only borizontally. The height of the mixing layer is lower at night than during daylight. The average daily beight is lower in winter than aummer.

uritium - A ndioactive isotope of the element hydrogen. Tritium is one of the principal prodvets of the SRS.

unplanned release - The release of abnormal quantities of radioiodine to the environment. This results from absormul operating conditions.

volatillzation - The process of transforming a material to the vapor atate from the solid state or from solution.

watershed - The ares of the earth's surfice that drains into a body of water.

weighting factor - A tissue-specific factor which equates the health risks from seloctive irmdiation of a given tiesue to the bealth rishs from uniform, whole-body exposure.

XOQDOQ - A computer code developed for the Nuclear Regulatory Commisaion to evaluate the transport and dispersion of atmospheric effluents.

$x$-ray - A photon that is emittod from the eloctron cloud surrounding a nucleus when un electron undergoes a innaition from a higher energy level to a lower energy level. In this report, this energy level transition typically is aseociated with radionctive decay of a nuclide. Because the transition is between specific energy leveln, the $x$-rny has a specific energy which is characteristic of the element the daughter nuclide belongs to. In the decay of typical isotopes of iodine found at SRS, zenon x-rays of approximately $30 \mathrm{keV}$ energy are emitted. 
Thu page intendfoandly lest blank 


\section{Preface}

Redioiodine, which is the collective term for all radionctive isotopes of the element iodine, is formed at the Savannah River Site (SRS) principally a \& by-product of nuclear resctor operations. Part of the radioiodine is released to the environment during resctor and reproceasing operations at the site. The purpose of this report is to provide in introduction to radioiodine production and disposition, its strus in the environment, and the radiation dose and bealth ricks as a consequence of its relenes to the environment. A rigorous dose reconstruction study is to be completed by the Center for Disense Control during the 1990.

The report covers the time period from the mid 1950s, when operations commenced, through 1989. The majority of the reporteci data for releases and environmental measurements are ansual average values compiled from the published reports cited in the Bibliography. These are public reports that have been periodically issued since the site was established. Results of special environmental studies thrt did not appear in such reports, but were sepanstely published, are cited within each chapter.
This report is one in series to evaluate specific redionuclides. The environmental consequences of various scenarios for possible clocure of wate sites are not addreased; such scenarios were published in SRS reports known as Environmental Information Documents. Accident scenarios for facilities are also not addressed in this report, but they were published in SRS reports known as Safety Analyzis Reports and Safety Information Documents.

The reports of this series are intended to be "living documents" that will be updated in future years. The author ecknowledge the efforts of numerous colleagues at SRS who helped in providing data and information. Among those are Dave Hayes, Larry Heinrich, Doris Hoel, Terry Killeen, and Lary Spradley. Deserving special acknowledgment are Vickie Amos, Vonette Boylaton, Felecia Brooks, Sarn Cole, Gloria Overstreet, and Bluine Ray who extracted environmental radioiodine concentrations from published reports and enterad the values into a database. The authors also extend their appreciation to Richard Shipley, Gary Evans, and Debre McCroskey for providing editorial support. 
This page intentionally left blank.

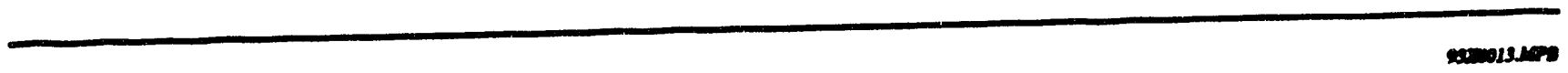




\section{Executive Summary}

The offsite done attributed to radianctivity released to the environment from the Savannah River Site (SRS) is small compared to the doee that individuals receive from all other sources. Radioiodine, s component of the released radionctivity, presents a negligible risk to the offsite population and environment in the vicinity of SRS.

The lifetime risk from radioiodine released to the atmonphere during 1955-1989 is 1.5 fatal cancer cases in the population residing within $80 \mathrm{~km}$ of SRS; the lifetime risk from all other caures of cancer is approximately 90,000 fatalities in that population. The lifetime risk due to aqueous relesses of redioiodine is 0.007 fatal cancer cases in the population consuming treated water from the Savannah River, that population will experience a lifetime risk of approximately 11,000 fatalities from all other causes of cancer. A relationship between cancer deaths and SRS radiojodine is not discernible.

Released radioiodine principally consists of ${ }^{131} I$ and ${ }^{22} \mathrm{I}$, which have half-lives of 8 days and 16 million years, respectively. Annual atmospheric and aqueous releases of radioiodine significantly decreased beginning in the 1960 s as stricter emission controis were implemented. No measurable quantitics of short-lived ${ }^{231}$ I released through 1989 remain in the environment as of $\mathbf{1 9 9 0 .}$

SRS released approximately 2,500 curies of ${ }^{131}$ I and 6 curies of ${ }^{12} 1$ to the atmosphere from 1955 - 1989. The releases cocurred during routine operations and one scute release incident. Nearly two-thirds of the total ${ }^{131}$ I was released during routine operations in one yen -1956. The scute atmospheric release incident occurred in 1961 when 153 curies of ${ }^{131}$ I was released from the chemical separations area over several weeks. The incident was due to the inadvertent reprocessing of shoit-cooled irradiated materials.

Atmospheric transport mechanisms distributed much of the SRS releases into the local offsite environment where SRS ${ }^{131}$ I was detocted in most years from 1955-1961. Since then it has been detected only intermittently.

The annual maximum dose to an offsite adult due to SRS radioiodine releases to the atmosphere ranges between 17 and 0.04 mrem. The 17-mrem dose occurred in 1956, the year of greateat ${ }^{131}$ I releases. Naturally-occurring radiation produces an annual dose of approximately $300 \mathrm{mrem}$ in the average adult residing in the local area.
Aqueous releases of radioiodine were directly discharged to site streams or to earthen seepage basins. The aqueous relesses were the result of routine operations and several failures of irradiated fuel elements.

Measured releases of ${ }^{131}$ I to streams total approximately 300 curies from 1957 - 1978; direct discharges to streams ceased in 1978. The maximum annual relesee of 87 curies to site streams cocurred in 1962. The streams are tributaries of the Sovananh River, which is a water supply for two downriver water treatment plants. Consumers of treated Savannah River water received a radiation dose from ${ }^{131}$ I that is minor compared to the dose from naturally-occurring radiation. The greatest annual maximum dose to the adult consumer is $0.3 \mathrm{mrem}$ in 1957.

The seepage basins received approximately 2,600 curies of ${ }^{131}$ I and 3 curies of ${ }^{12} / 1$ during 1955 - 1989. An unknown fraction of radioiodine volatilized from the basin to the atmouphere. Other radioiodine migrated with the banin water into the ground. Near the seepage basins in the F chemical separations area, the migrating ${ }^{12} / \mathrm{I}$ contaminates a shallow geological formation, the Santee Formation, which is a source of drinking water elsewhere at SRS. However, the drinking water is not contaminated with ${ }^{22} \mathrm{I}_{\text {; the }}$ contaminated groundwater flows in the opposite direction from the B and Savannah River Laborntory areas, which are the only SRS areas that use Santee water. Furthermore, Upper Three Runs Creek cuts through the Santee Formation to physically isolate the ecource of the drinking water from the contaminated water. The abeence of elevated tritium concentrations in the drinking water confirms that the drinking water is not contaminated with ${ }^{10}$; contaminated groundwater contains approximately $10^{5}$ greater concentretions of tritium than ${ }^{12 \%}$.

Migrating shallow groundwater principally resurfaces adjacent to Four Mile Creek after a transit time of at least 14 yean. The maximum ${ }^{22} /$ concentration observed in resurfaced groundwater is $410 \mathrm{pCi} / \mathrm{L}$. The resurfeced groundwater becomes diluted as it drains into Four Mile Creek, which drains into the Savannah River. Concentrations of ${ }^{12} \mathrm{I}$ in the river water are typically less than 1 percent of the EPA drinking water standard of $1 \mathrm{pCi} / \mathrm{L}$. Consumers of treated Savannah River water receive an insignificant dose from migrating ${ }^{12 \%}$.

This report serves as an introduction to the consequences of radioiodine releases. A rigorous reconatruction atudy is to be completed by the Center for Disease Control during the 1990 . 
This page intentionally left blank. 
The radioactive isotopes of the element iodine are collectively referred to as radioiodine. The two principal isotopes of incerest in this report are ${ }^{132}$ I and ${ }^{131}$ I, which have radiological half-lives of 16 million years and 8 days, respectively.

Because all isotopes of iodine essentially have the same chemical and biological characteristics, radioiodine and stable iodine behave identically in the environments the food chairs and the human body. Iodine, an essential element to nutrition, is principally found in the thyroid of the human body. Ingested radioiodine contributes to the radiation dose that humans receive from all sources.

Natural and mannade radioiodine are introduced in this chapter. They are discussed in the context of the global environment, regional environments in the vicininy of manmade sorvces, and specifically the environment in the vicinity of the Sowarnah River Sice (SRS). 


\section{Radioiodine in the Global Environment}

Mechaniems for production of natural radioiodine include the interaction of cosmic rays with the earth's atmosphere and fisaion of uranium and thorium in the earth's cruat. Fisaion of uranium and thorium occurs principally by spontaneous fission (Edwarda 1962). Radiosctive isotopes of iodine are among the products of the fission mechanism. Cosmic nys interact with xenon in the earth's atmosphere to produce radiviodine through nuclear resctions (Edwards, 1962). Eseentially, the only radioective isotope of iodine to survive the transit time between production in the atmoephere and deposition on the earth's surface is $2 \%$.

The global inveatory of antural 120 s eccumulated over the lifetime of the earth is eatimated to be 10 curies in the terreatrial eavironment and $\mathbf{3 0}$ curies in oceans and the atmosphere (NCRP, 1983). Nuclear wespons leating, which began in 1945, bas introctuced approximately 10 curies of 121 into the atmoephere (NCRP, 1983); radioiodine is produced by fission reactions when a nuclear weapon is detonnted.

Atmospheric nuclear weapons testing is the greateat source of manmade redioiodine in the giobal environment. Weapons teating has released approximately $1.4 \times 10^{10}$ curies of 13II into the atmoephere (Eisenbud, 1987a). A significant part of the radioiodine from these sources has been deposited as global fallout on the earth's surfeco-predominantly in the northern hemisphere. The USA, UK, and USSR censed atmoupheric teating of nuclear weapons in 1962. Since then, as a result of radionctive docay, the ${ }^{131}$ in the global environment has generally decreased to immeas urably small concentrations. Oocesional atmospheric teats conducted by Chine and France reintroduced ${ }^{\text {BII I to the }}$ environment for short periods of time; however, no atmoepheric teats have been conducted by any nation since 1980 .

Two auclear ruactor eccidente- the satellite Coumos 954 in 1978 and the Chernobyl nuclear reactor socident in 1986-released radioiodine to the global environment. The USSR satellite Cosmos 954 was powered by a nuclear reactor, which was estimated to have contained 4,900 curies of '13I upou reentry into the earth's atmosphere (Eisconbud, 1987b). The satellite disintegrated upon reentry and distributod radioiodine throughout the upper atmosphere of the northern hemisphere.

The Chernobyl sccident in the USSR is extimated to have released $7.3 \times 10^{6}$ curies of ${ }^{131}$ I (USSR, 1987). Based on measurements of the ratio of ${ }^{131}{ }^{13}{ }^{12}{ }^{21}$ in environmental samples (Puul et al., 1987), it is extimated that 0.2 curies of 1291 were released to the environment. Accident conditions were severe enough to inject some of the radioiodine into high altitudes, which allowed radioiodine to be distributed throughout the northern hemisphere. 


\section{Radioiodine in Regional Environments}

Tho impact of globally-distributed manmade radioiodine is generally greater near the source than at diatant locations. Fallout from events such as the Chernobyl reactor sccident and atmospheric teating of nuclear weapons was more significant in their respective regional environments than in the global environment.

A nuclear weapons teat conducted underground may also release radioiodine to the atmosphere. Volatile forms of iodine may escape to the atmosphere through fissures, which form in the ground as a reault of the explosion. Such an incident was detectr. I in five Europenn countries following an underground teat by the USSR in 1987 (Bjurmen of al, 1990).

In addition in Chernobyl, other reaca. socidents have released radioiodine to regional environments. Fourteen land-baned auclear reactor accidents involving damage to the reactor core there been reported (Eisenbud, 1987c). The greated quantities of ${ }^{131}$ I were released in the four sccidents shown in Table 1-1. Other than at Chernobyl, sccident conditions were not severe enough to result in the distribution of large quantitiea of radioindine beyond regional eavironments.
Under normal resctor operating conditions, radioiodine is cesentially contained within the irradiated fuel and targets. Only small quantities of radioiodine are released to regional environments as a reault of the normal operation of experimental, research, power, and production nuclear resctors.

Nuclear fuel reprocessing operations are the moet siomificant rustained source of radiojodine releseces rince the 1940. Reprocesaing facilities are located in reveral countries and are used to chemically separate materials irradiated in experimental, research, power, and nuclear materials production reactors. As a result of the chemical separations process, part of the rediojodine content of irradiatad miterials can be released to the environment through atmospheric and aqueous effluents.

Table 1-1. Eramples of radioiodine released in land-based nuclear reactor socidents

\begin{tabular}{l|llcl}
\hline Year & Country & Reactor & $\begin{array}{l}\text { Curles 111 } \\
\text { Released }\end{array}$ & Reference \\
\hline 1986 & USSR & Chernobyl & $7,300,000$ & USSR, 1987 \\
1979 & USA & Three Mile Island & 15 & Pasedag and Pootma, 1986 \\
1961 & USA & SL-1 & 10 & Eisenbud, 1987c \\
1957 & UK & Windecalc & 20,000 & Eisenbud, 1987c \\
\hline
\end{tabular}




\section{Radioiodine in the SRS Environment}

Tho US Department of Energy's Savannah River Site, which was previously known as Savannh River Plant, was eatablished in 1951 as a government-owned contractor-operated facility to manufacture special nuclear materials-principally uritium and plutonium - for national defense purposes. The fint production nuclear reactor began opention in late 1953. Reproceseing of imadiated materials in chemical separations facilities began in late 1954. SRS is located in the central Savannah River area of South Carolin (sec Figure 1-1;)

Numerous redionctive irotopes of iodine are formed as byproducts during the irsdintion of fuel and targets. Moat of the isotopes are short lived and decay to insignificant sctivity level between the end of irratiation and the beginning of reprocesaing. Becaune of half-life considerntion, " 1 I and 1 are the only radionctive inotopes of iodine consistently roleased to the environment a a reult of normal operations.

Atmospheric releases through 1989 totaled approximutely 2,500 curies of ${ }^{131}$ I and 6 curies of ${ }^{12 \%}$. Site streams received approximately 300 curies of ${ }^{131} \mathbf{l}$; such discharges were terminnted in 1978. All of the ${ }^{131}$ I released through 1989 decayed to immearumbly low levels by the end of 1990; bowever, excentinlly all of the 121 released throughout the hintory of SRS remuins distributed in the environment.

Releases of 19 represent a very emall part of the total releases of all radionuclides from SRS. However, ${ }^{12} 1$ contributes a large part of the ofieite population doce from SRS relenses In 1989, 19 accounted for only $2 \times 10^{\text {s }}$ percent of the total radionctivity relensed from SRS to the atmosphere; bowever, it sccounted for 13 percent of the offsite population dose. These facts illustrate the signifi- ennce of the very long half-life of ${ }^{22} 1$, it mobility in the environment, and the pathway to humans. (Corresponding values for ${ }^{231} I$ in 1989 were $1 \times 10^{-7}$ percent of releases and 2 $\times 10^{-3}$ percent of dose.)

The offirite population dose due to all SRS relenses in 1989 was emall compared to the overall done that mepbers of the general public received from all rediation sources. Figure 1-2 showe that SRS releases in 1989 sccounted for approximately 0.006 percent of the dose from ionixing rediation received by members of the population in the vicinity of the sito-those residing within $80 \mathrm{~km}$ of SRS and thoce convuming treated water from the Savannah River. Atmopheric ${ }^{29}$ I releases comprised 13 percent of this 0.006 percent. Therefore, the importance of redioiodine is apparent only in the context of SRS dome contributions; on the cale of overall environmental doses, redioiodine is a minor consideration.

The chepters that follow deacribe the origin and disposition of redioiodine at SRS, mensured releases and inventories, reaults of routine measurements and specinl studies in the environment, and an aseasment of the done and risk to the population due to SRS radioiodine relesses. 


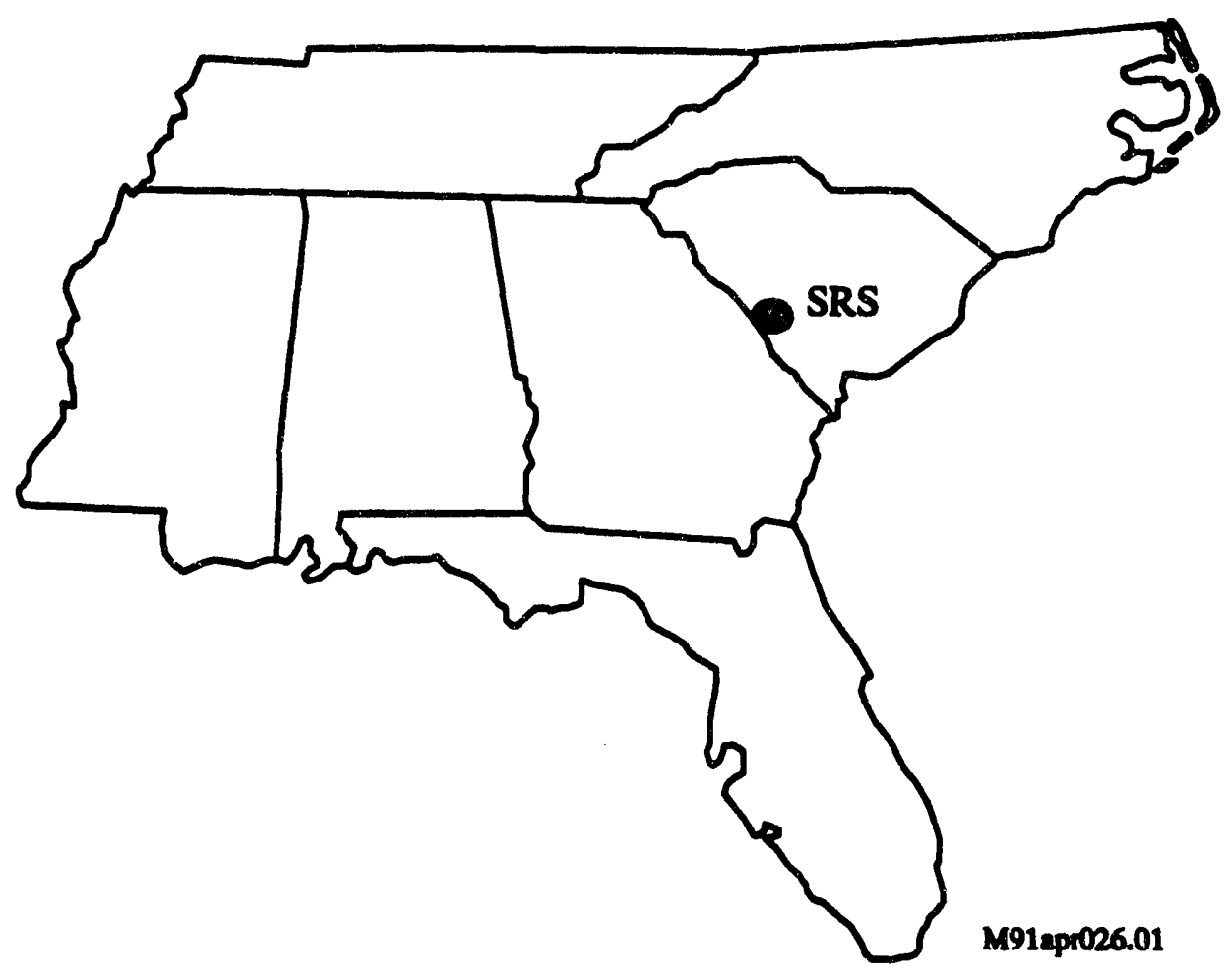

Fyegure 1-1. Location of SRS in the Southeastern United States

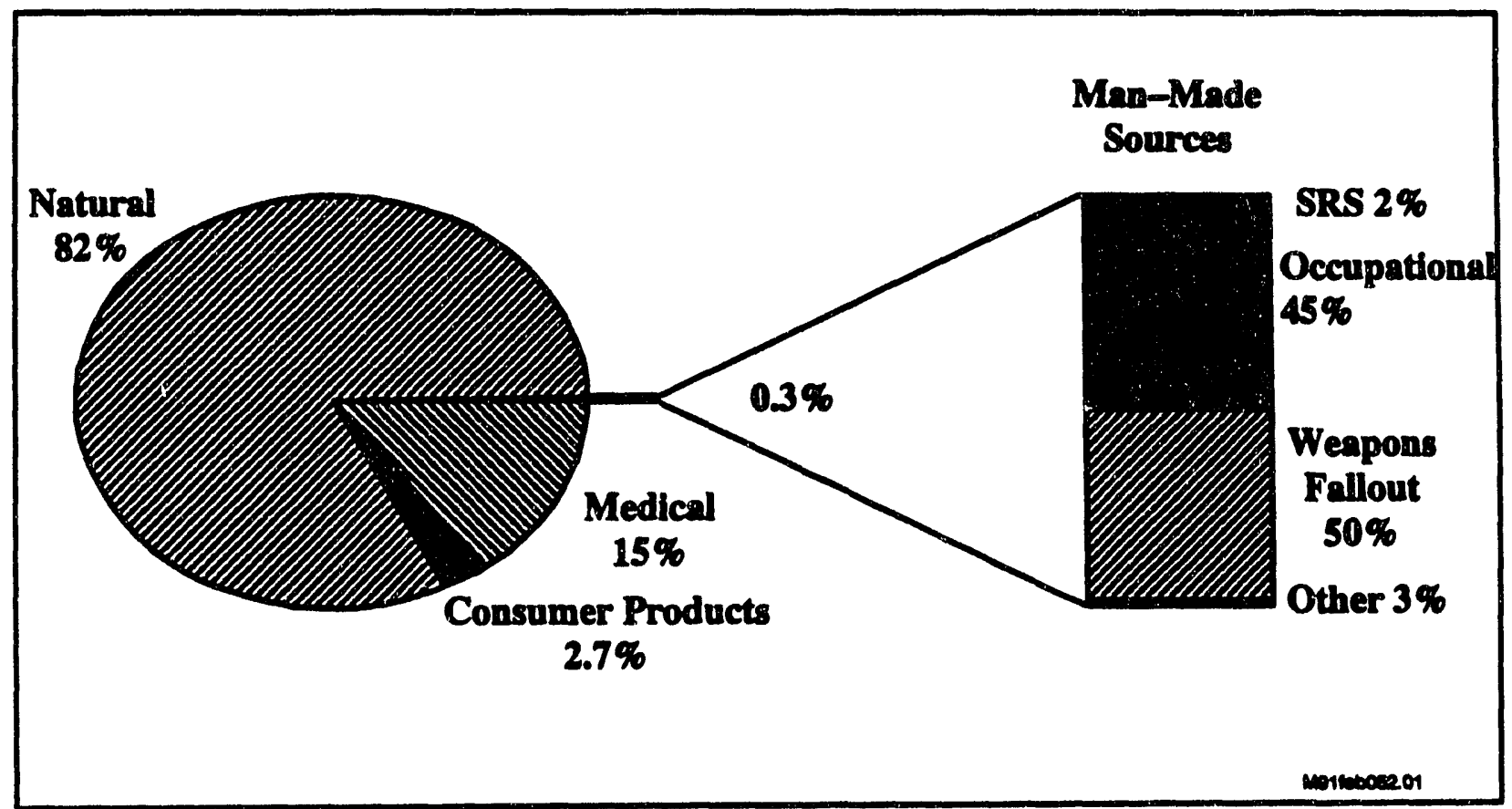

Figure 1-2. Relative Contributions from Various Sources to the Total Radiation Dose (225,200 pernon-rem) for the Population in the Vicinity of SRS in 1989 


\section{References for Chapter 1}

Bjurman, B., L DeGeer, I. Vintereved, A. L. Rudjord, F. Ugletveih H. Aeltonen, K. Sinkko, A. Rantavaara, S. P. Nieleen, A. Antrog, and W. Kolb, 1990, "The Detection of Radioactive Material from a Venting Underground Explosion", Journal of Environmental Radioectivity 11,1 .

Edwarda, R. R., 1962, "Iodine-129: Its Occurrence in Nature and Its Utility as a Trecer", Science 137, 851.

Bisenbud, M. 1987, "Environmental Radioactivity", Academic Preas, Orlando, p. 336.

Eisenbud, M., 1987b, "Environmental Radioactivity", Academic Preas, Orlando, p. 367.

Eisenbud, M, 1987c, "Environmental Radioactivity", Acaa. demic Preas, Orlando, p. 225.

NCRP, 1983, "lodino-129: Evaluation of Releases from Nuclear Power Generation", NCRP Repont 75, National Council on Radiation Protoction and Measurements, Betheada, MD, pos. 4, 5, 8, and 9.
Pasedag, W. F., and A. K. Postme, 1986, "Impset on Future Licensing", in: "The Throe Mile Island Accident", L. M. Toth, A. P. Malinauskas, G. R. Eidam, and H. M. Burton, Eds., Symposium Series 293, American Chemical Society, Washington, DC, p. 275.

Paul, M., D. Fink, G. Hollos, A. Keufman, W. Kutchera, and M. Magaritz, 1987, "Measurement of ${ }^{121} 1$ Concentrations in the Environment After the Chernobyl Reactor Accideut", Nuclear instruments and Methods in Physics Research B29, 341.

USSR, 1987, "Information on the Accident at the Chernobyl Nuclear Power Station and its Consequences Prepared for IAEA", Soviet Atomic Energy (English Translation) 61, 845. 
This chapter gives a general overview of the origin, uses, and dispasition of radioiodine at SRS under normal operating conditions. The locations of SRS facilities that have or had the potential to release radioiodine are shown in Figure 2-1. The chemical separations and reactor facilities have the greatest potential to release radiaiodine. They are located near the center of the 800-square-kilometer Savannah River Site. The history of measured releases from specific SRS facilities is presented in Chapter 3. 


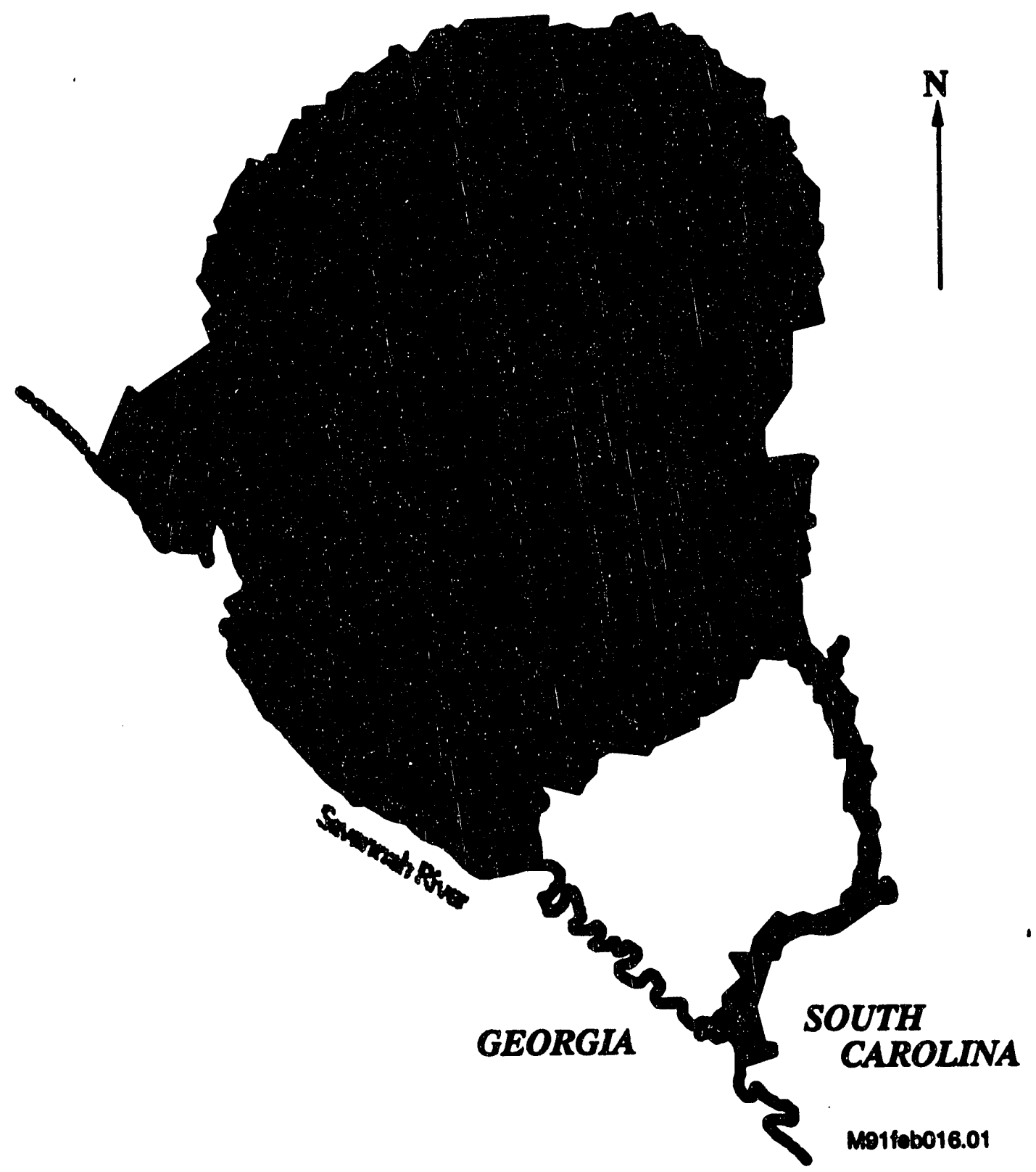

Facilities Legend

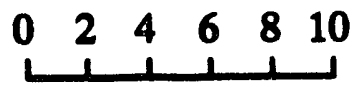

B HWCTR

C,K,L,P,R Reactor Areas

Kilometers

D Heavy Water

F Chemical Separations + Naval Fuels

H Chemical Separations + RBOF

$M$ Raw Materials

SRL Savannah River Laboratory

SWDF Solid Waste Disposal Facility

T TNX Semi Works

Flegure 2-1. SRS Facilitics with the Potential to Release Radioiodine 


\section{Origin of Radioiodine at SRS}

Radioiodine at SRS predominantly originates in the fuel and targets that are irradiated in the nuclear materials production resctors. Other site operations and offsite sources contribute to the inventory of radioiodine at SRS.

\section{Irradiation in Production Reactors}

Moat of the radioiodine a SRS is formed as a by-product in the nuclear fuel and targets during operation of the production reactors. The principal mechanism for production of radioiodine is neutron-induced fiseion. When a reactor is operating, neutron-induced fission reactions occur in the ${ }^{20} \mathrm{U}$ fuel of the reactor core. The reactions form a variety of fission products, which include isotopes of iodine.

In addition to fissica products, each neutron-induced fission reaction in the fuel produces several neutrons, some of which induce additional fission reactions and maintain a chain reaction. Some of the remaining neutrons interact with target materials in the resctor. (Fuel and targets are encapsulated separately and referrod to as elements.) One such internction, neutron capture in a $20 \mathrm{U}$ target, results in the production of a special nuclear material, ${ }^{20} \mathrm{Pu}$.

In certain target materials, such as 20 , neutron-induced fission is a competing resction with neutron capture. Fission also occurs in some of the target's minor constituents, such as ${ }^{200} \mathrm{U}$ and ${ }^{200} \mathrm{Pu}$ in ${ }^{200} \mathrm{U}$ targets.

Table 2-1. Inventory of redioiodine produced in "representative" material irradiated in SRS production reactors.

\begin{tabular}{|c|c|c|c|c|c|}
\hline \multirow[b]{2}{*}{ Isotope* } & \multirow[b]{2}{*}{ Haterire } & \multicolumn{4}{|c|}{ Curtes Remaining at Vartooss Times After Eod of Irradiation } \\
\hline & & 0 sec & $24 \mathrm{hr}$ & 100 daye & 200 days \\
\hline 2001 & $25 \mathrm{~m}$ & $1.5 \times 10^{4}$ & - & $\ldots$ & - \\
\hline 127 & $1.6 \times 10^{7} y$ & $2.3 \times 10^{-1}$ & $2.3 \times 10^{-1}$ & $2.5 \times 10^{-1}$ & $2.5 \times 10^{-1}$ \\
\hline $130 \mathrm{~T}=$ & & $9.2 \times 10^{4}$ & - & - & - \\
\hline 1300 & $12 \mathrm{~h}$ & $1.4 \times 10^{5}$ & $3.5 \times 10^{4}$ & - & - \\
\hline${ }^{131}$ I & $8.0 \mathrm{~d}$ & $7.6 \times 10^{7}$ & $7.0 \times 10^{7}$ & $1.3 \times 10^{4}$ & $2.3 \times 10^{\circ}$ \\
\hline${ }^{132}[$ & $2.3 \mathrm{~h} / 3.3 \mathrm{~d}^{* *}$ & $1.1 \times 10^{8}$ & $8.9 \times 10^{7}$ & - & - \\
\hline 133 & 98 & $3.8 \times 10^{6}$ & - & - & - \\
\hline 139I & $21 \mathrm{~b}$ & $1.8 \times 10^{8}$ & $8.2 \times 10^{7}$ & - & - \\
\hline${ }^{13 M} \mathrm{~F}$ & $4 m$ & $1.3 \times 10^{7}$ & - & - & - \\
\hline 134 & $53 m$ & $2.0 \times 10^{3}$ & $1.3 \times 10^{0}$ & - & - \\
\hline${ }^{130} \mathrm{I}$ & $6.6 \mathrm{~h}$ & $1.6 \times 10^{\circ}$ & $1.5 \times 10^{7}$ & - & - \\
\hline${ }^{130} \mathrm{p}$ & $47 \mathrm{~s}$ & $5.0 \times 10^{7}$ & - & 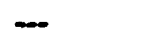 & - \\
\hline 130 & 83s & $7.9 \times 10^{7}$ & - & - & - \\
\hline 137I & $24 s$ & $7.9 \times 10^{7}$ & - & - & - \\
\hline${ }^{130} \mathbf{I}$ & 78 & $4.1 \times 10^{7}$ & - & - & - \\
\hline 1391 & 28 & $1.8 \times 10^{7}$ & - & - & - \\
\hline 1007 & $<18$ & $4.1 \times 10^{5}$ & - & - & - \\
\hline${ }^{141}$ I & $<1 \mathrm{~s}$ & $8.6 \times 10^{5}$ & - & - & - \\
\hline 142 I & $<1 \mathrm{~s}$ & $1.1 \times 10^{5}$ & - & - & - \\
\hline Totals & & $1.0 \times 10^{\circ}$ & $2.6 \times 10^{\circ}$ & $1.3 \times 10^{4}$ & $2.5 \times 10^{\circ}$ \\
\hline
\end{tabular}

- "m" designates a metastable energy state greater than the ground state of a particular isotope.

** Until chemically separated, ${ }^{139}$ (2.3-hour half-life) is in equilibrium and decays with the 3.3-day half-life of its ${ }^{132}$ Te parent. 
The total inventory of radioiodine in the core of an operating production reactor is spproximately $10^{\circ}$ curiea. This inventory is echioved within eoveral days after each startup of the reactor. It remains at that level until the reactor is shut down after a specified irradintion time. The radioiodine inventory comprises approximately 6 percent of the lotal fiesion-product inventory during resctor operation.

The inventory of the individual iodine isotopes is shown in Table 2-1 as a function of time after the end of irradiation. The data in Table 2-1 demonstrate that radioiodine setivity lovels quickly decrease after reactor stutdown. For example, only 26 percent of the inventory at the end of irradiation remains after 24 bours. The data also demonetrate that it is prudeat to allow the irrediated material to cool for about 200 days before reprocesaing through chemical sepantions.

The inveatory of each iodine isotope was calculated with the SHIELD computer code for "representative" irradiated material. (See Glocary for a deceription of SHIELD.) This material represents the variety of operational parameters that were used from 1953 to 1988 . These include composition of fuel and targets, irradiation time, and reactor power level.

\section{Other Sources Due to SRS Operations}

Small quantities of radioiodine have been produced at SRS by teat reactors, spontaneous fisaion, and neutron ectivation analysis. The activity levels of radioiodine from these sources are insignificant when compared to the activity levels in irradiated nuclear fuel and targets; bowever, these sources are discussed in the following subsections to provide a complete overview of potential radioiodine releases.

\section{SRS Test Reactors}

Several small nuclear reactors were in use at two SRS locations from the 1950s through the 1970. The Heavy Water Components Test Reactor (HWCTR), locuted in B Area, was used in the early 1960 s to teat prototype fuels for a propoeed heavy water power reactor. The other teat reactorn were located in M Area and were used from the mid-1950 to the late 1970. The Process Development Pile and the Lattice Test Reactor were used as zero-power mock-up facilities to test components for the production reactors. The Subcritical Experimental Pile was aleo used to teat component designs. The Standard Pile provided neutrons for experiments such as neutron rediography and neutron setivation.

\section{Spontaneous Fission}

Spontaneous fission is a rediosctive docay mode that occurs in heavy elements such as uranium. It produces neutrons and fievion-product radioiodine and is one of the mechanisms for the production of radioiodine in nature. The occurrence of spontaneous fiscion ranges from rare to frequent.

An example of a radionuclide that rarely docays by spontuneous fission is $20 \mathrm{U}$. The equilibrium concentration (sce Gloseary for explanation) of fiesion-product ${ }^{131}$ is approximately $0.0008 \mathrm{pCi} / \mathrm{g}$ of ${ }^{20} \mathrm{U}$, which is exentislly equal to its equilibrium concentretion in natural uranium. (The $20 \mathrm{U}$ content of natural uranium is $99.3 \mathrm{atom}$ percent). The inventory of ${ }^{131}$ I due to spontancous fission of uranium in nature within the boundary of SRS is $10^{\circ} \mathrm{pCi} / \mathrm{cm}$ of soil depth. This is based on the average abundance of 4 parts per million for uranium in the earth's cruat. If a $100-\mathrm{cm}$ soil depth were considered, the ${ }^{{ }^{31} I}$ inventory within the site boundary would be $10^{5} \mathrm{PCi}$, or $10^{6}$ curies.

Uranium uned in operations at SRS has been chemically purified. Because of it short half-life, "21I attains the equilibrium concentration with the $20 \mathrm{U}$ in SRS uranium within several weeks after chemical purification. In contrast, long-lived 20 I does not reach equilibrium; this would require tems of millions of years after chemical separation. Conequently, Iis enentially nosexistent in SRS uranium that has not been irradistod, but becaure of the age of the earth, 11 does exiat in uranium in nature.

An example of a radionuclide that frequently decays by epontaneous fission is ${ }^{25} \mathrm{Cl}$. The equilibrium concentration of ${ }^{131} \mathrm{I}$ is approximately $2 \times 10^{13} \mathrm{PCi} / \mathrm{g}$ of ${ }^{252} \mathrm{Cf}$. This high concentration, almost one curie per gram, is due to the frequent occurrence of spontaneous fiscion and the 2.6-year half-life of ${ }^{252} \mathrm{Cr}$.

Because $250 \mathrm{Cf}$ frequently docays by epontaneous fission, it is a valuable neutron source. It has been produced in SRS reactors by the irrediation of ${ }^{24} \mathrm{Cm}$ targets. From the mid 1960 until 1987, the Sevannab River Laboratory (SRL) fabricated incustrial and medical ${ }^{202} \mathrm{Cf}$ sources for offaite we. Some of the sources have been retained at SRS for neutron calibrations in the ${ }^{22} \mathrm{Cf}$ fabrication facility and for use in two neutron setivation fecilities at SRS. One ${ }^{252} \mathrm{Cf}$ neutron sctivation facility was operated in M Area in the 1970, and the other has been operational a SRL since the mid 1970 .

The spontaneour-fission-produced radioiodine present inside the encapeulated ${ }^{252} \mathrm{Cf}$ sources at the SRL ${ }^{20} \mathrm{Cf}$ Neutron Activation Analyais Fecility (NAAF) as of 1979 was calculated for a safety anslysis (Winn, 1979). The major 
iodine isotopes are shown in Table 2.2 together with the curies of each isotope that would be expected to volatilize in the event of a source failure. The potentially volatilized component represents $40 \%$ of the radioiodine inventory in the source.

Other isotopes of uranium and isotopes of thorium, plutonium, and curium also spontancously fission. One or more of these materials have been used in M Area, the reactor areas, the chemical eeparations areas, the Naval Fuels Facility, TNX Semi-works, or SRL.

\section{Neutron Activation Analysis}

Neutron ectivation analysis is an analytical tochnique for measuring elemental compositions in materials. The ${ }^{252} \mathrm{Cf}$ neutron activation facilities, the Standard Pile, and the $C$ and $\mathrm{K}$ production reactors have been used for that analysis. For example, from the late 19703 to mid 1980s, environmental samples were activated in C Reactor to determine uranium content. Traces of fission-product radioiodine were produced in the irradiated samples. From 1971 to 1984 iodine concentrated from environmental samples was activated in K Resctor to detect trace levels of ${ }^{22}$ I; small quantities (typically less than $10^{\text {s }}$ curies) of the activation products ${ }^{130} \mathrm{I},{ }^{12 \mathrm{I}}$, and ${ }^{121} \mathrm{I}$ were produced in the irradiated samples.

Table 2.2. Portion of radioiodine inventory in the ${ }^{252} \mathrm{Cf}$ NAAF as of 1979.

\begin{tabular}{l|l}
\hline Isotope & Curles* \\
\hline${ }^{131} I$ & 0.13 \\
${ }^{132 !}$ & 0.18 \\
${ }^{133 I}$ & 0.28 \\
${ }^{131}$ & 0.33 \\
${ }^{139} \mathrm{I}$ & 0.40 \\
${ }^{136} \mathrm{I}$ & 0.34 \\
${ }^{137} \mathrm{I}$ & 0.17 \\
${ }^{130 I}$ & 0.07 \\
${ }^{139} \mathrm{I}$ & 0.02 \\
\hline Total Radioiodine & 1.92 \\
\hline
\end{tabular}

- Activity represents only the portion of the inventory that is predicted to volatilize in the event of a source failure. This is $\mathbf{4 0}$ percent of the inventory.

\section{Materials Originating Offsite}

Certain fuels irradiatod at offsite non-commercial facilities are shipped to SRS for reprocessing. While awaiting reprocessing, the fuel is stored in the Receiving Basin for Offsite Fucl (RBOF), which is located in $H$ Area.

The isotopes ${ }^{123} \mathrm{I},{ }^{22} \mathrm{I}$, and ${ }^{131} \mathrm{I}$ are purchased from commercial vendors typically in quantities less than $10^{-3}$ curies. The isotopes are used at SRS for experimental purposes, such as chemical yield determination, instrument calibration, and determination of retention charecteristics and chemical properties of iodine on various absorbers. These isotopes are predominantly used in SRL. The amount of radioiodine present at SRS due to commercial purchases is insignificant when compared to the amount produced in fuel and targets at SRS production reactors or stored in RBOF.

SRS and it's vicinity have been subjected to global fallout of man-made radioiodine since the 1940s. Most global fallout has occurred because of atmospheric nuclear weapons tests. 


\title{
Disposition of Radioiodine at SRS
}

The principal means for diepocing of radioiodine are containment and time. Table 2-1 shows that very short-lived isotopes of iodine produced in SRS reactors docay to inaignificant activity levels ahortly after end of irradiation. By 200 days of cooling, ${ }^{131}$ I and 221 are the only isotopes of iodine remaining in measurable quantities. Their total activity is 2 parts per billion of the original radioiodine activity at the end of irradiation. To describe the disposition of the longer lived isotopes, the sources of redioiodine are categorized as follows:

\author{
Major Sources \\ - fuel and targets irndiated in production reactors \\ - certain fuels irredinted offsite \\ Minor Sources \\ - fuel and targets irradiated in SRS teat reactors \\ - spontaneous fimion \\ - neutron sctivation samples \\ - commercially purchased radiojodine \\ - global fallout
}

\section{Radioiodine in Fuel and Targets Irradiated in Production Reactors}

Under ideal operating conditions, radioiodine is contained within the cladding of fuel and target elements during irradiation and cooling. Cooling is the interval between the end of irrediation and the beginning of chemical separations. Irradiated materials are stored underwater in reactor basins for moet of the cooling time, which was approximately 100 days during the initial years of operation. This was increased to approximately 200 days by the mid-1960s.

Under normal operating conditions, it is poesible for traces of radioiodine to eacape from irradiatod fuel and target elements to the environment through small defects in the cladding. Air and water at reactors are monitored for wuch possible releases. Actual releases are described in greater detail in Chapter 3.

After the cooling period, fuel and targets are treated in the chemical separations areas to recover the desired products from the waste products such as radioiodine. In chemical separations part of the isdine volatilizes. The primary emission control is a silver-nitrate resctor to remove iodine from process air before the air is exhausted to the atmosphere through a 61-m stack. The silver-nitrate reactor consists of ceramic chips, also known as beryl anddlea, coatod with silver nitrate. Iodine passing through a bed of chipe resets with silver nitrate to form solid silver iodide.
Speat chips were washed and reused in the early years of operations. The wash solutions were proceased and stored in underground tanks for radiosctive waste. In later yearsepent chips were buriod in the Solid Wate Dispoeal Facility (SWDF), which was previously known as the burial grounds. This prectice was terminated in the early 1980 . Since that time chips have been stored at the SWDF.

Radioiodine contaminates aqueous wastes at the chemical separations facilities. The wastes are evaporated and then sent to underground stonge tanks for radiouctive waste. The condenante from evaporation was sent to the separations area seepage basins until November 1988 when use of the seepage basins was terminated. Since then condensate has been sent to the Effluent Treatment Facility where it is treated to remove radionuclides and chemicals before being discharged to Upper Three Runs Creek.

Moat of the atmospheric and aqueous effluents in the chemical separations areas have been monitored for possible radioiodine releases. Monitoring techniques and measured releases are deacribed in Chapter 3.

The disposition of long-lived ${ }^{22}$ I produced during the first 20 years of chemical separations processing is eatimated to be 40 percent stored in waste tanks, 30 percent buried in the SWDF, 20 percent released to the atmosphere, and 10 percent released to seepage basins (Cornman, 1974). The releases to the atmosphere and seepage basins and the burial in 
the SWDF have had a direct impect on the environment. Environmental radioiodine is discussed in detail in Chapter 4.

\section{Radioiodine in Certain Fuels Irradiated Offsite}

Irradiated fuels received from certain offisite facilities are stored underwater in RBOF until the fuel is ready for chemical separations. The fuel then enters the regular process atream in $\mathbf{H}$ Aren. The disposition of radioiodine becomes the same as deccribed for fuel irradiated in SRS production resctor.

\section{Radioiodine in Fuel and Targets Irradiated in Test Reactors}

Fuel and targets from the various teat reactors were primarily sent to the RBOF for cooling before chemical separations. Some were sent to SRL for research or to reactor materials fabrication facilities. Reactor materials fabrication facilities only received fuel or targets that were not irradiated; this material was blended into the standard fabrication process for targets and fuel to be used in the production renctors.

\section{Radioiodine from Spontaneous Fission .}

Radioiodine produced by spontaneous fission in heavy elements is retained by these elements as long as they remain encapsulated.

\section{Neutron Activation Analysis Samples}

Environmental samples are analyzed by high sensitivity neutron activation for the detection of trace levels of uranium and 129 . Typically, the uranium analysis is non-destructive; therefore, any radioiodine produced from fission of uranium is not released. The radioiodine content is minute and the amples are dispoeed in the SWDF as solid redionctive waste.

The analysis for ${ }^{12} 1$ typically involves chemical purification of iodine at SRL after irradiation. In the purification steps, traces of the activation products ${ }^{22} \mathrm{I},{ }^{122} \mathrm{I}$, and ${ }^{230} \mathrm{I}$ are released to the SRL exhaust system. None of these trace releases are significant enough to be detected in routine radioiodine monitoring of the stacks. Traces of radioiodine are retained in various liquids used in the purification steps and then stored in the SRL temporary waste tenks. Purified radioiodine in solid form is subjectod to various messurements and allowed to decay to inconsequential levels before it is buried in the SWDF.

\section{Commercially Purchased Radioiodine}

The isotopes ${ }^{22} \mathrm{I},{ }^{22} \mathrm{I}$, and ${ }^{131 !}$ are purchased from commercial vendors for use, typically, at SRL. The disposition of radioiodine is similar to that described for neutron activation analysis samples.

\section{Global Fallout Radioiodine}

During the era of extensive atmospheric nuclear weapons testing (1950s and early 1960s), global fallout was one of the principal sources of radioiodine in the local environment; SRS was the other principal source. Chapter 4 presents a discussion of environmental radioiodine.

\section{References for Chapter 2}

Comman, W. R., 1974, "Estimation of ${ }^{129}$ Distribution in SRP Separations Processes", DPST-74-533, E. 1. du Pont de Nemours and Company, Aiken, SC.

Winn, W. G., 1979, "Safety Analysis of the ${ }^{252} \mathrm{Cf}$ Neutron Activation Facility", DPSTSA-700-20 (Revision 10/79), E. I. du Pont de Nemours and Company, Aiken, SC. 
This page intentionally left blank.

2-8

armotseas 
This chapter presents a discussion on radioiodine at SRS facilities in terms of passible release pathways, emission control features, and annual releases to the aqueous and atmospheric environments. The reported annual releases are taken from public reports cited in the Bibliography.

Routine operations at SRS facilities release radioiodine to the abmosphere, sise streams, and seepage basins. The seepage basins allow short-lived radionuclides to decay to very low levels during the transit time (years) required for aqueous migration from the basins through the ground to site streams. The most significant releases of radioiodine occurred during the early years of site operasions. The greatest releases originated in the $F$ and $H$ chemical separations facilities and the reactor facilities, all of which are located near the center of the 800 -square-kilometer site. The praximity of these facilities to major streams within the boundary of SRS is shown in Figure 3-1, which also shows the location of other facilities that had the potential to release radioiodine. 


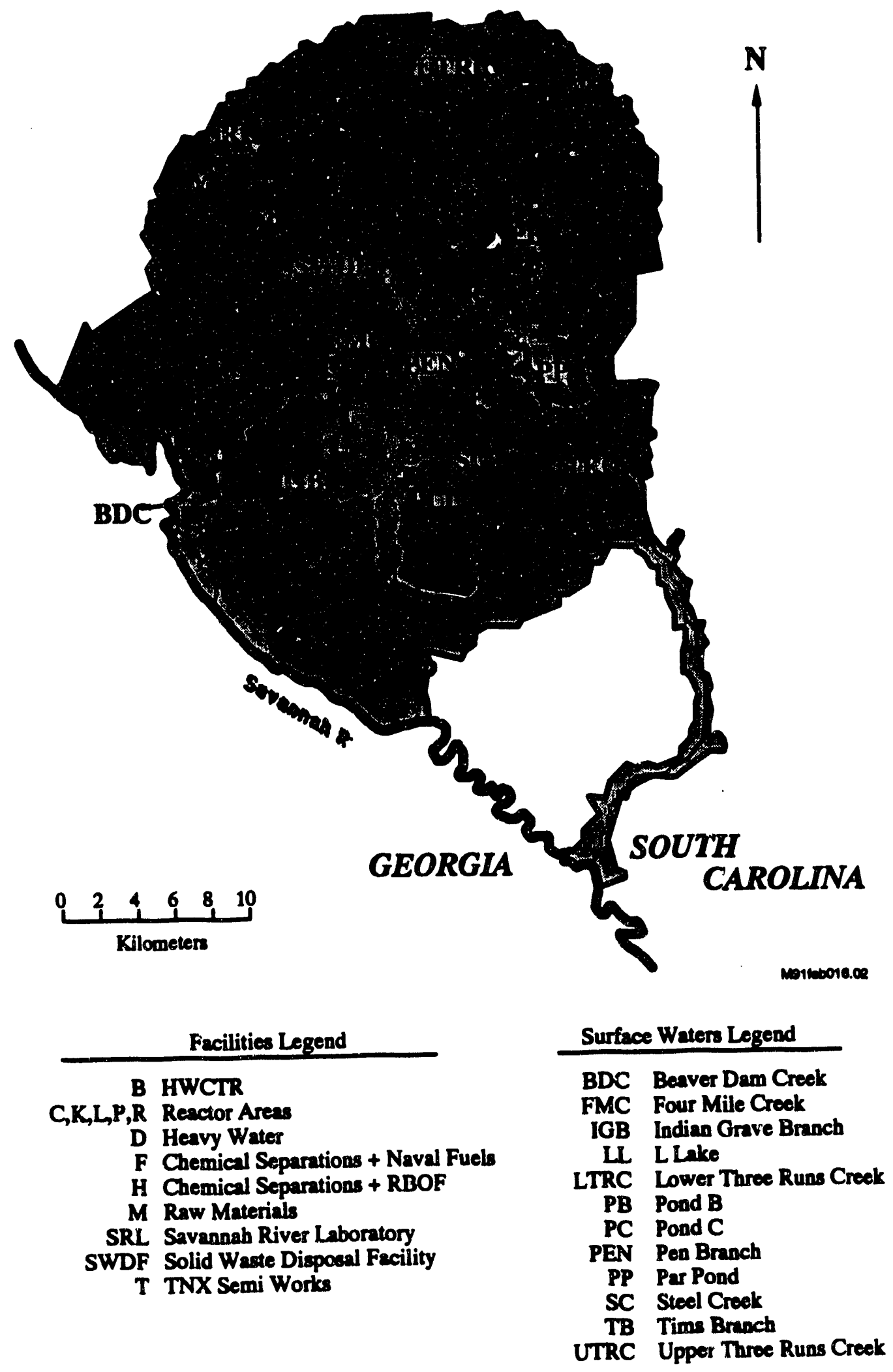

Frgure 3-1. Proximity of Site Streams to SRS Facilities that had the Potential to Release Radioiodine 


\section{Reactor Facilities}

The five production reactors at SRS are identified by the letter designations $C, K, L, P$, and $\mathbf{R}$. The reactors were designed to irradiate specific targets to produce special nuclear materials-principally tritium and plutonium-for national defenee purposes. Certain ndionuclides for other governmental purposes are also produced, such es ${ }^{200} \mathrm{Pu}$, which is - prwer source for certain deep-epece missions.

\section{Facility Operations}

After the reactor became operational in 1953-1955, they did not operite continuously. They were periodically shut down for maintenance, anfety upgrades, or replecement of fuel and targets. In 1988 three reactors were shut down for extensive maintenance and anfety uperades; prior to 1988 one resctor had been placed on inactive status and another on standby.

The principal components of the reactor core are the fuel, targete, control rods, and moderator. When a nuclear resctor is operating, nuclear fission resctions occur in the ${ }^{25} \mathrm{U}$ fuel of the reactor core. Fission can also occur in certain target materiala. Control rods are neutron-absorbing materials that are pocitioned in the core to control the rate of fission reactions in a reactor.

The moderntor in SRS reactors is beavy water, which is circulated around the fuel and target elements in the reactor core. The moderator decreases the kinetic energy (slows the speed) of neutrons emitted in the fission process. Slow neutrons have a greater probability than fas neutrons for producing the decired auclear ravetions in fuel and target materials. The moderator also functions as the primary coolant to remove heat generated by auclear reactions and radiosctive decay in fuel anc target elements. Heat is then transfierred from the moderator by beaf exchangers to the secondary coolant. SRS reactors use either river or pond water as the secondary coolant.

In reactors that use water from the Savannah River, the river water passes through the shell side of the beat exchanger and discharges to a site stream that flows to the Savannah River. Reactors that use pond water discharge the secondary coolant from the heat exchanger to a canal that flows to a series of cooling ponds. Cooled pond water is recirculated through the heat exchanger.

Under normal operating conditions, fuel and target elements are irradiated for a specified time, removed from the reactor core, and stored underwater in the disassembly basin of the reactor building. Storage in the disessembly besin for the cooling period, which by the mid 1960 was at least 200 days for moet irradiated materials, allows shon-lived radionuclides to docay to low levels before the reprocessing of the fuel and targets begins in the chemical separations areas.

The abnormal condition of a fuel or target failure, which consiats of a major breech of the encapsulation material, is detected by sensors in the resctor. When a failure occurs, the reactor is shut down and the failed element is transferred into a container called a "harp". The harp is stored underwater in the reactor basin and vented to the resctor stack. Failures occurred more frequentily in the early yesrs of operation than in later yesrs.

\section{Pathways for Riviease}

During normal renctor operations, traces of radioiodine cacupe from irradiated fuel or turget elements if a defect develops in the cladding. The defect iypically is a microscali creck. If a defert devilops while the element is in the reactor cose, radioiodine rapes irom the irrediated material to the noderator by volatilization or by leaching of radioiodine from the exposed irradiuted material.

In the more serious case of a failod elessent, some of the expoeed uranium and plutonium can become dispened in the moderator. After a failed element is removed, the dispersed uranium and plutonium continue to sirculate with the moderator until they are removed from the moderator by an onlins ion exchange purification process. Neutrons generated disring subeequent resctor operation cause fission in any residual circulating uranium and plutonium, thereby producing small quantities of radioiodine directly in the moderntor.

Once radioiodine is in the moderator, it can circulate with the moderntor, adsorb onto surfaces, migrate to the blanket gas above the moderator, or be removed by the online purification proces.s.

Similar pathways occur in the disassembly besin during cooling of irradiated materials. Radioiodine escapes to basin water from cladding microdefects by volatilization or by leaching of radioiodine from the exposed irradiated material. Water also leaches adsorbed radioiodins, from the 
exterior murfoces of fuel and targets. Once ndioiodine is in the banin water, it circulates with the water, adeorbs onto arfaces, migrates to the sir above the basin, or is removed by the barin doionizer.

Circulating moderator and basin water are the principal pathways by which equeous radioiodine is released from reactors to the environment. If a leak exist in the resctor beat exchanger, moderator can mix with the secondary coolunt. Any radioiodine relensed by this pathway is not quantified; however, the secondary coolant is monitored for beta-onmm sctivity. Lealnge to the secondary coolunt is a minor pathway compared to the diensembly basin pathway.

Initially, diser rembly basin waters were purged directly to site tream to remove the beat genented by the atored irmadiated fuel and targets. After intallation of besin bent exchnagers, deionizers, and filters in the 1960s, the volume of purge water decreased significantly as did the relenses of radionctivity.

Periodic purges are necessary to eliminate tritium, the sccumulation of which reaults in exposure to operating personnel. Any residual radioiodine that is not removed by the deionizer is relensed with the purge water, which has been dischurged to earthen seepage basins or atreams. Dischurges to tream ceased in 1978.

A minot sours of wastewater that contains radioiodine is the resctor process sewer system. This syatem principally rasiven cooling water from the shell side of the beat exchengen for revtor basins and miscellaneous process waters. Proceses ewer water is periodically sampled and analyzed for radionuclides.

Other restewater is collected in process sumps at the resctor fecilities. Occasionally, this wastewnter contain moderator from leaks that developed during reactor operntions or spills that occurred when line breals were made during maintenance perioda. The watewrter is collectod and andyzed for both radionuclides and moderator. Poasible disposition methoda, depending on andysis revults, have been to proceas through the Heavy Water Rework Facility or the waste evaportion in the separations areas, or to discharge to seepage basins or streame.

Circulating moderator and disasembly basin water are also the principal sources for atmoepheric releases from resctors. Insoluble volatile forms of iodine in the moderator migrate, as vapor, into the blanket gas system above the moderator. Certain soluble forms of iodine volatilize in the moderator and migrate into the blanket gas system. Leaks and cocanional purges of the blanket gas system allow radioiodine to be relessed to the procees ventilation system.
Volatilization from moderator lealos or spills also introduces radioiodine into the process ventilation system.

Air in the process ventilation syrem parses through a confinement system, which includes a carbon filter bed designed to remove radioiodine, and then exhausts to the atmoepheric environment from a 61-m atack. During periods when the resctor is shut down for repairs, mintemance, or replacement of fuel and targets, air from the resctor building levels that are 6 and 12 meters below grade elevation bypeseses the carbon bed enroute to the steck. This bypers occurs because a hage air flow is required to remove tritium from procees areas where work is performed. The capacity of the carbon bed is ineufficient to handle an air flow that is 2 to 3 times greater than normal for an extended period of time. The capability exists to repidly switch airfow to the carbon filter in an emergency.

In the disanembly basin water, ituoluble volatile forms of iodine migate, as a vapor, to the air above the besin. Certin soluble forms of iodine volutilize in the water and migrate to the air above the basin. The air above the disaseembly basin is direstly exhousted to the outcide atmosphere, except for harp storage contriners, which are vented to the process ventilation system.

Certain form of iodine volutilize in the reactor ceepage benias and migrate to the atwoephere at ground level- reactor seepage basins are open to the environment.

\section{Emission Control}

Various measures have been implemented to minimize releases of redionctivity. One of theac is the extensive improvements in the quality of materials fabricated for irradiation. Such improvements minimize the formation of defects in the cladding of fuel and targets.

In the reactor areas, dischnrges of dinnsembly barin water to streams were reduced begin ing in 1963 when the water whe recirculated through beat exchangers for cooling and through deionizers for removal of radionuclides (except tritium). Prior to 1963 dinasembly basin water was purged continuously to site streams. Although the deionizers were offective in removing particulates, permanent and filten were installed in the late 1960 s to muintain water clarity. The rexidues collected on the sand filters are transported to $F$ Area to be procesesed and stored in waste tanks. Spent deionizer resin is transported to H Area for regeneration.

Because the heat exchangers, deionizers, and and filter sccount for the removal of beat, most radionuclides, and particulater, only the sccumulation of tritium prevents the 
indefinite recirculation of disassembly basin water. To reduce tritium expocure to workers in basin areas, basin water is periodically purged to site streams or to reactor seepage basina. No purges to site streams occurred after 1978.

Most of the redioiodine released in the early years of reactor operation originated in failed fuel elements. Resctor stack monitors and reactor core sensors detect failures or suspect failures of elements. In 1957 the practice of placing failed elements in harp atorage contuiners was implemented.

Under normal operation conditions, moderator and some residual ndionuclides adhere to fuel and target surfaces. When fuel and targets are removed from the reactor core, they are flushed with water to eliminate most of the adhered moderator and some residual radionuclides, such as redioiodine. This process was implemented in the late 1960. After flushing, the elements are stored in the dissasembly basin during the cooling time. The flush water is collected in drums for treatment in the D-Area Heavy Water Rework facility.

Atmospheric releases are minimized by the use of the confinement syatem, which is intended for routine operations and for a reactor incident. The system consists of a demister filter bank, a high efficiency particulate air (HEPA) filter bank, and the carbon filter bed. The latter consists of activatod charcosal impregnated with 1 percent triethylenediamine (TEDA) and 1 percent potassium iodide to enhance the retention of several chemical forms of iodine. The carbon filter removes greater than 99.9 percent of the iodine from the process ventilation air.

Controls have been implemented to provide sufficient cooling time for short-lived radioiodine to docay to insignificant levels before reprocessing. The cooling time for most irradiated materials at SRS was approximately 100 days initially, but by the mid 1960 s this increased to approximately 200 days. In response to an scute release incident in 1961, administrative controls (such as computer inventory of irradiated materials), and physical controls (such as an underwater ionization chamber to monitor shipments) were implemented to ensure sufficient cooling time has elapsed before reprocessing. In the 1961 incidenth excessive ${ }^{131}$ I was released due to the inadvertent reprocessing of very short-cooled material. After these controls were implemented, no other acute radioiodine release incident of this magnitude has occurred.

\section{Release Monitoring}

Although reactor stack air is continuously sampled for radioiodine, it has not always been quantified for the curies of radioiodine released. Continuous sampling is scoomplishod by passing a portion of stack air through a filter that traps iodine. The filter is changed weekly and analyzed for radiosctivity. Until the early 1960 , a filter paper conted with silver nitrate was usod; an sctivated charcosal filter, which is treated with TEDA to enhance collection of organic forms of iodine, replaced the filter paper.

The initial procedure to determine atmoepheric radioiodine releases was to measure the air filters for gross beta-gamma activity. The filters were submitted for laboratory analysis of ${ }^{131}$ I only if activity was detected above background. When the procedure was changed in the early 1970 s to perform laboratory analysis specifically for ${ }^{231}$ by gamma spectrometry, the releases of ${ }^{131}$ I from reactor stacks became quantified. Releases of ${ }^{12 \%}$ from reactor stacks were not quantified until late 1988 when laboratory analysis for long-lived ${ }^{22}$ I in the charcoal filters by low energy photon spectrometry began.

Similur procedures have been used to determine radioiodine releases to the air above the dinassembly basins. The published annual atmospheric release value for ${ }^{131}$ I from a reactor is the sum of stack and disassembly besin air relesses. Analysis for ${ }^{122} 1$ is not performed.

Several tochniques are used to monitor aqueous releases. Secondary cooling water from the reactors is monitored for beta-gamma activity, but not specifically for ${ }^{131} \mathrm{I}$. Basin purge water was not routinely analyzed for ${ }^{131}$ I until about 1960. Prior to that time, laboratory analysis was performed only if beta-gamma setivity was detected. Specific analysis for ${ }^{120} \mathrm{I}$ is not performed because of the low probability of ${ }^{120} \mathrm{I}$ being preacent relative to ${ }^{131}$ I (Table 2-1, page 10). Similarly, water from other release points, such as process sewers, is andyzed for ${ }^{131}$ I but not for ${ }^{12} 1$.

\section{History of Measured Releases}

Annual aqueous and atmospheric releases of ${ }^{131} I$ from individual reactors are presented in the sections that follow. The aqueous releases are the measured discharges from the disassembly basins. Other releuses (such as from heat exchengers, leaks, and sumps) are minor and are not 
included in the diecuncion of aqueous releases from individual reactors; they are included in a summary section for reactor releasen.

The greatest measured equeous releases of 131 I from reactors occurred during 1957 and the early 1960 . Thene releasen were typically aseocinted with fillures of irradiated fuel elements. No meacurements of short-lived isotopes, such as ${ }^{20} \mathrm{I}$ and ${ }^{20} \mathrm{I}$, were reported at the time of thene ${ }^{21 I} \mathrm{I}$ releases. The high-yield fiacion products 121 and 200 would atill bave been present is significant quantities if the releaces occurred within soveral days afler ead of irradiation (Table 2-1, page 10).

No measurements for ${ }^{2}$ were conducted at the time of the greateat aqueous 's'I releacer; however, the information in Table 2-1 leads to the conclusion that the corresponding ${ }^{22} T$ releases were insignificant. For example, the ectivity of ${ }^{21}$ relative io 'MI I is only one part in 300 million at 24 bours after shutdown of an SRS production resctor.

Routioe atmoepheric releases of ${ }^{131}$ I from reactors wcre not quantified until approximately 1972 . Releases of ${ }^{131}$ I 10 the atmouphere ure minor compared to the aqueous releasea.

Atmospheric relanses of ${ }^{20 I}$ were quantified after late 1988. No 11 has been detected from any of the reactors. Although these 121 mesturements were conducted during the extended shutdown, the atmospheric release of ${ }^{21}$ during reactor operation is expected to be iserignificant. This is bocause the ectivity of ${ }^{12}$ I relative to ${ }^{21}$ I is extremely amall curing reactor operation, and the atmoespheric releases of ${ }^{111}$ I have been amall.

\section{Reactor}

C Reactor was operational from 1955 until it was shut down for extensive maintenance in 1986; it was placed in standby mode in 1987. Disnsembly basin purges were discturged into Four Mile Creek ind three seepage basins designated 904-66G, -67G, and -68G. The seepage besins were used from 1959 to 1970 and from 1978 through 1986.

The total measured aquoous releases of ${ }^{131}$ I from C Reactor during its operational lifetime are 21.8 curies to Four Mile Creek and 1.0 currie to the seepage basins. The greateat annual releases, approximately 4 curies to Four Mile Creek, occurred in 1961 and 1963 as shown in Figure 3-2.

The total measured atmoopheric release of ${ }^{131}$ I during the operational lifetime of C Reactor was 0.042 curien. Measured ansual atmospheric releases of ${ }^{21}$ I from C Reactor are shown in Figure 3-3.

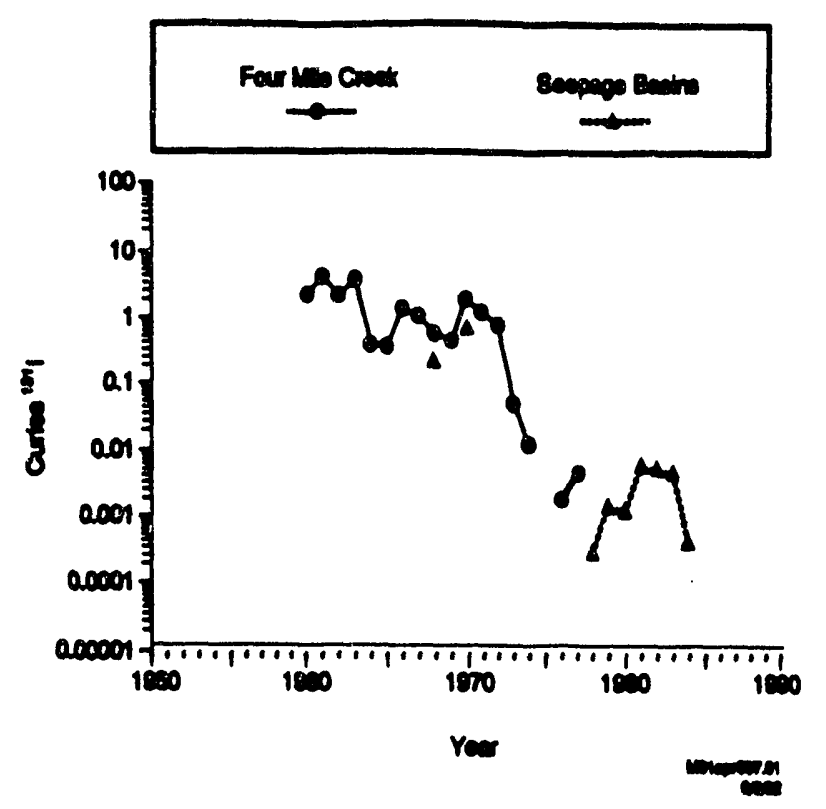

Thare 3-2. Measured Anaual Aqueous Releasces of ${ }^{311}$ from C Reactor

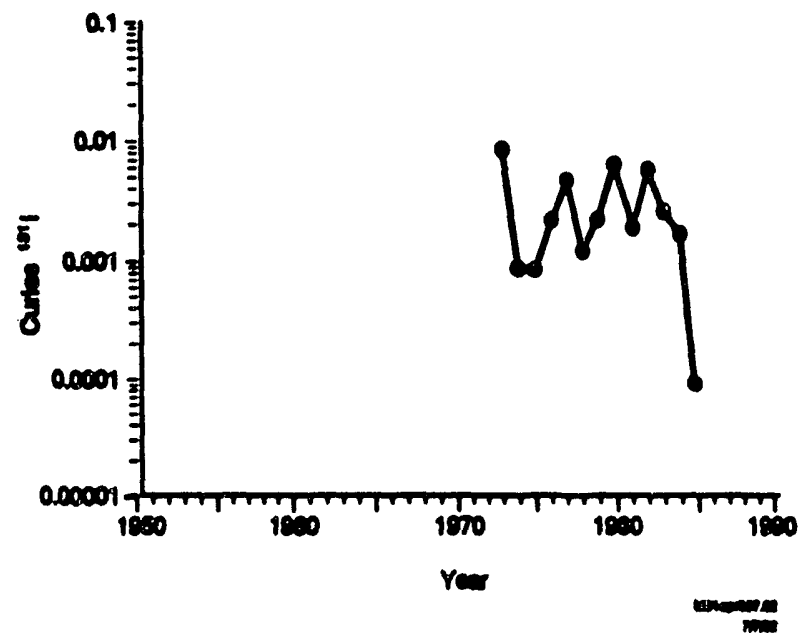

Degure 3-3. Measured Annual Atmospheric Releases of irI from C Reactor

\section{K Reactor}

K Reactor was operational from 1954 until the shutdown for extensive maintenance and safety upgrader, which began in 1988. Disanembly besin purges were diecharged to Pen Branch and to two earthen besine- reepare basin devignuted 904-650 and a retention besin decignated 904-88G. Because roepage baxin $904-65 \mathrm{G}$ had poor recpage 
charecteristice, it received disasembly basin purges only in 1959,1960 , and 1965. Retention besin 904886 received disnrembly basin purges and occasional miscellaneous wastewater discharges from 1966 through 1989.

The total messured aqueous releases of ${ }^{131} I$ from $\mathrm{K}$ Reactor through 1989 are 30.1 curies to Pen Branch and 21.6 curies to the earthen basins. Messured annual aqueous releases of ${ }^{131}$ I are abown in Figure 3-4. The maximum annual release, 14 curies to the retention basin, occurred in 1969.

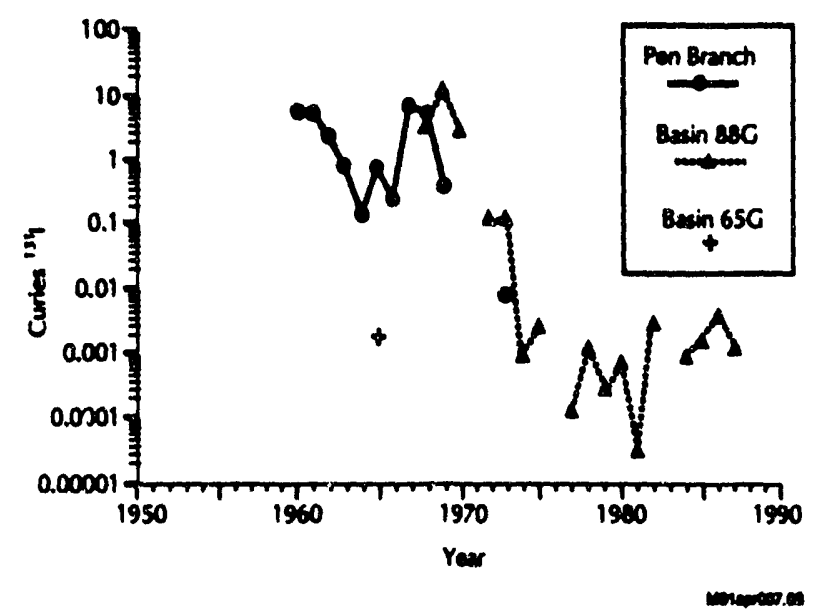

Migure 34. Measured Annual Aqueous Releases of ${ }^{131}$ I from K Resctor

The total measured atmospheric release of ${ }^{131} I$ from $K$ Resctor through 1989 was 0.036 curies. Measured annual atmospheric releases are shown in Figure 3-5.

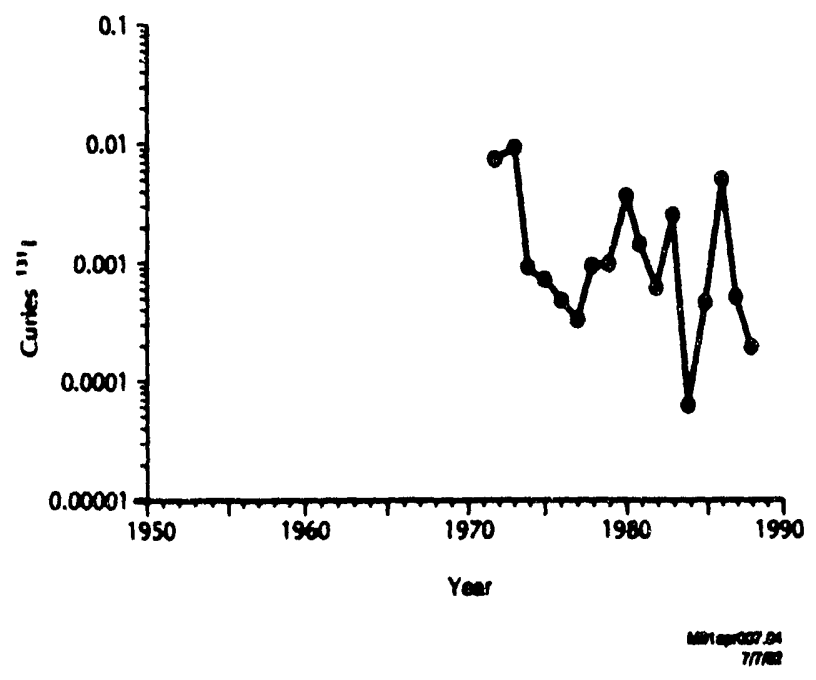

Fgure 35. Messured Annual Atmospheric Releases of ${ }^{131}$ I from K Reactor

\section{Reactor}

L Reactor was operational from 1954 until 1968 when it was pleced in standby. It was refurbished in the early $1980 \mathrm{~s}$, restarted in 1985, and operated until the 1988 shutdown. To provide thermal mitigation of secondary cooling water from the restarted reactor's heat exchanger, L Lake was constructed in the early 1980 by damming Steel Creek. Therefore, during L Resctor's second operational period, secondery cooling water from the resctor beat exchanger was discharged to L Lake which drains into Steel Creek.

Disassembly basin purges were dischurged to Steel Creek and a seepage besin (904-64G). The seepage basin was used intermittently from 1958 to 1969 and 1985 through 1989. The L-Area Oil and Chemical Basin (904-83G) was used from 1961 to 1979 to receive wastewater containing various oils and chemicals from all of the resctor areas. It is adjacent to the $904-64 \mathrm{G}$ seepage basin.

The total measured equeous releases of ${ }^{131}$ I from $L$ Renctor through 1989 are 34.7 curies to Steel Creek and 1.8 curies to the scepage basins. Measured annual aqueous releases of ${ }^{131}$ I are shown in Figure 3-6. The greatest annual releases, approximately 8 curies to Steel Creek, occurred in 1961 and 1964. In its second operational period, aqueous ${ }^{131}$ I was not discharged to Steel Creek.

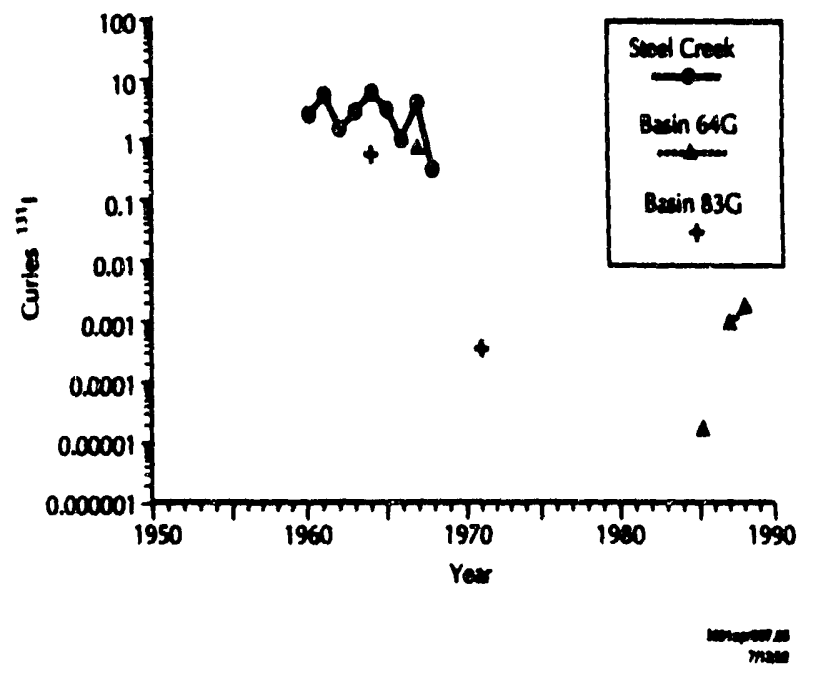

Plgure 3-6. Measured Annual Aqueous Relenses of ${ }^{131}$ I from L Renctor

The total measured atmospheric release of ${ }^{131}$ I from $L$ Resctor through 1989 is 0.0007 curies. During L Resctor's firat operational period, ${ }^{131}$ I atmospheric releases were not quantified. Measured annual atmospheric releases of ${ }^{231}$ I from L Reactor are shown in Figure 3-7. 


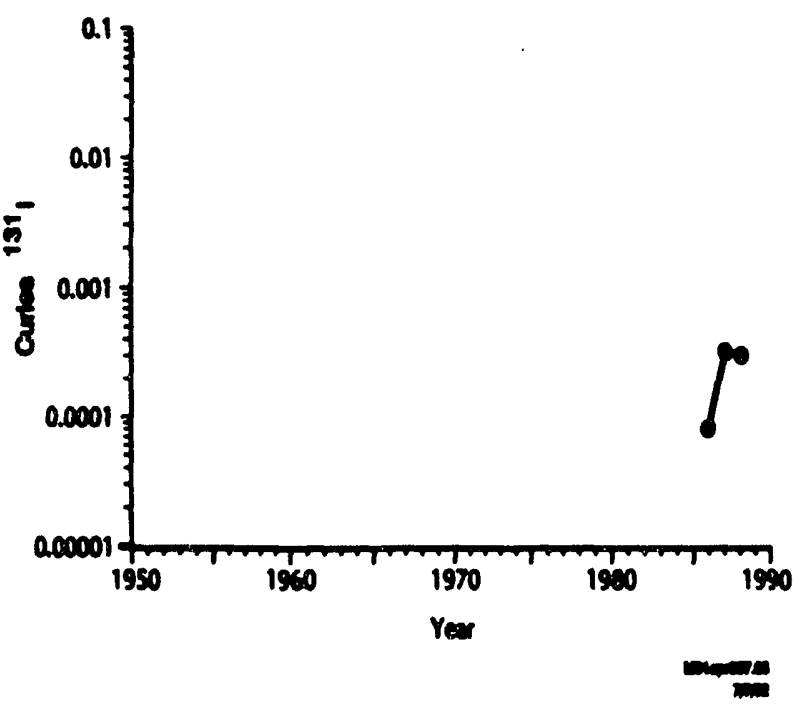

Frgure 3-7. Measured Anoual Atmoepheric Releases of "in I from L Reactor

\section{P Reactor}

P Resctor was operational from 1954 until the 1988 shutdown. Disassembly basin purges were intermittently discharged to Steel Creek and Par Pond (1954 to 1977) and to three seepage basins (1957 through 1989). The seepage basins have dexignations 904-61G, -620 , and -63G.

Reactor cooling water and miscellnneous effluents were dischurged to Stoel Creak until 1963; moet of the cooling water was then diverted to Par Pond. When L Lake was constructed in the mid 1980, all aqueous effluents from P Reactor were diverted to Par Pond.

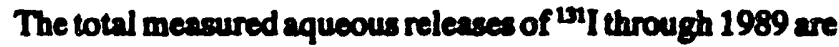
159 curries to the Steel Creek/Par Pond syatem and 0.2 curries to the reepage basins. Measured annual squeous releases of ${ }^{131}$ I are shown in Figure 3-8. The greated annual releasces, approximately 70 curies to Steel Creek, cocurrod in 1957 and 1962 due to failed fucl elements. These were the greateat squeous releases of ${ }^{231}$ I from SRS to site streams.

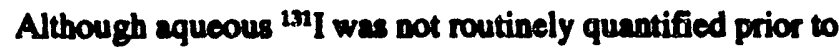
1960 , the value for 1957 probably represented special analysee in response to failures of newly designed fuel elements.

The total measured atmospheric release of ${ }^{231}$ I from P Resctor is 0.055 curies through 1989. Measured annual atmospheric releases of ${ }^{231}$ I from P Reactor are shown in Figure 3-9.

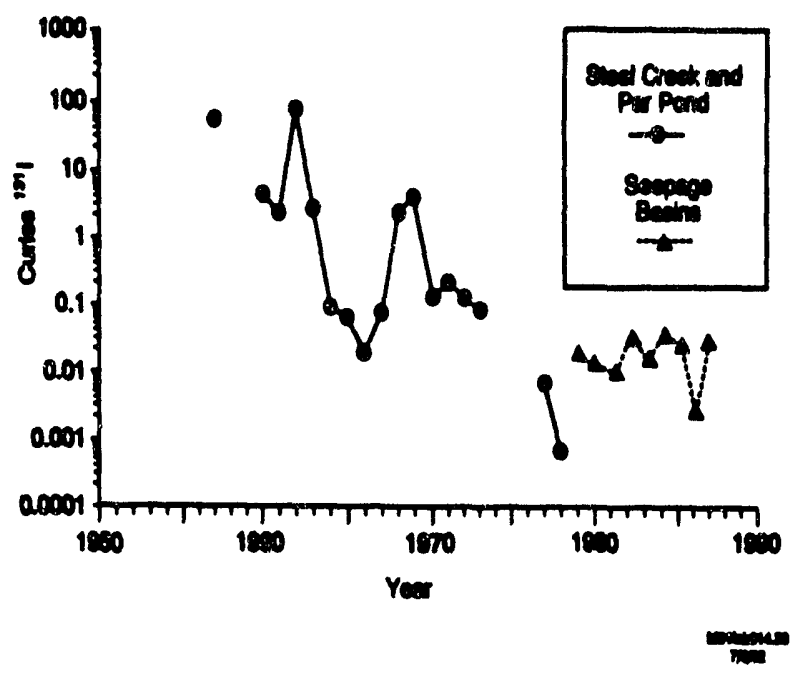

Drgure 3-8. Measured Annual Aqueous Releases of ${ }^{131}$ from P Resctor

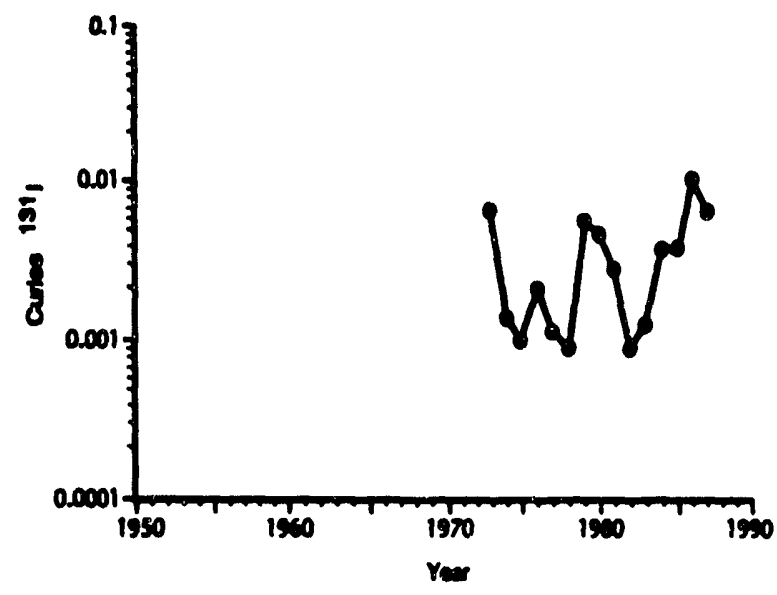

Mremex

Fizare 3-9. Measured Annual Atmoapheric Releases of inI from P Reactor

\section{R Reactor}

R Reactor was the fird operational production reactor at SRS. It operted from late 1953 until 1964 when it was pleced on insective status. Disarembly besin water was discharged into Lower Three Rums Creek from 1954 to 1958, into Par Pond from 1958 to 1964, and into a seepage besin aystem from 1957 to 1964. R Reactor had six reepage baxins dexignnted 904-103G, -104G, -57G, -58G, -59G, and -600 . 
The original reepage basin, 904-103G, was used only from June to December 1957. Use of this basin was terminated duc to aurface outcropping and leakage into an abandoned sewer. The basin was backfilled in 1958. Basins 904-104G, $-57 G,-58 G$, and -590 were in use from 1957 to 1960 . These four basins were deactivated, beckfilled, and covered with asphalt in 1960. Basin 904-60G was in use from 1958 to 1964; it was backfilled in 1977.

Reactor secondary cooling water and miscellaneous effluents were discharged to Lower Three Runs Creek from 1954 to 1958. After 1958 these effluents were discharged to Par Pond, which was constructed by the damming of Lower Three Runs Creek. Beginning in 1961 discharges to a canal and pond system that eventually drained into Par Pond (Figure 3-1) replaced direct discharges into Par Pond.

The total measured aqueous release of ${ }^{131}$ I from R Reactor curing its operational lifetime is 56.2 curies (all of the ${ }^{131}$ I was discharged to the Par Pond system). Measured annual aqueous releases of ${ }^{131}$ I from $R$ Reactor are shown in Figure 3-10. The maximum annual release of 35 curies occurred in 1963.

Atmospheric releases of ${ }^{231}$ I were not quantified during the operational lifetime of $\mathbf{R}$ Reactor.

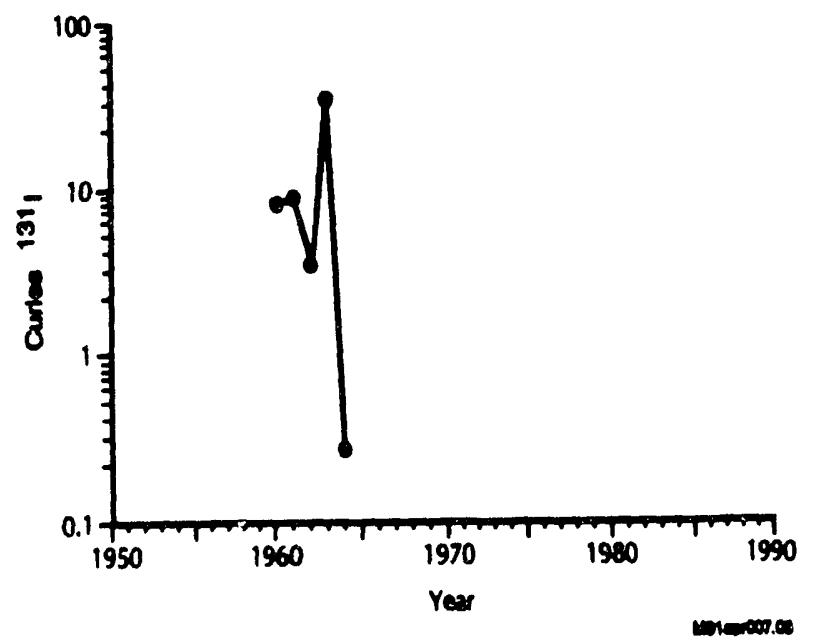

Frgure 3-10. Measured Annual Aqueous Releases of ${ }^{131}$ I from R Reactor into the Par Pond System

\section{Summary of Reactor Releases}

The total measured aqueous release of ${ }^{131}$ I from reactor areas through 1989 is 327 curies. This includes disessembly basin releases of 302 curies to site streams and 24 curies to carthen basins. Minor aqueous releases (euch as from heat exchangers, leaks, and sumps) contributed 1 curie to site streams. The total measured atmospheric release of ${ }^{131} I$ is 0.13 curies.

The sums of the measurod annual aqueous releases of ${ }^{131}$ I from all resctors are shown in Figure 3-11. By the 19803 annual releases had docreased to approximately 0.1 percent of the annual releases in the early 19603.

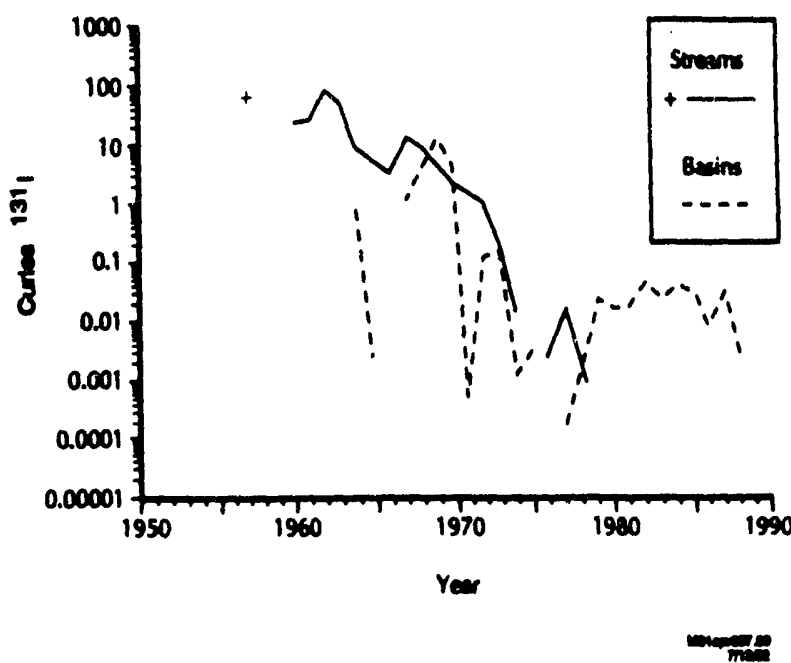

Figure 3-11. Combined Measured Annual Aqueous Releases from Reactors

Atmoepheric releases of ${ }^{131}$ are shown in Figure 3-12. Although ${ }^{131}$ I atmospheric releases were sot quantified prior to 1972, those releases are catimated to have boen small. This estimate is based on the lack of specific laboratory analyses for ${ }^{231} I$ in stack air filters; wuch analyses would have been performed if excess beta-gamma activity were detected on the filters.

Atmospheric releases of ${ }^{10} \mathrm{I}$ were quantified beginning in 1988; ${ }^{20} 1$ releases are below detection limits. Prior releases when reactors were operational are expected to have been insignificant. This is because the setivity of ${ }^{22} 7$ is orders of magaitude smaller that the activity of ${ }^{131} \mathrm{I}$, and the atmospheric releases of ${ }^{131}$ I have boen small. 


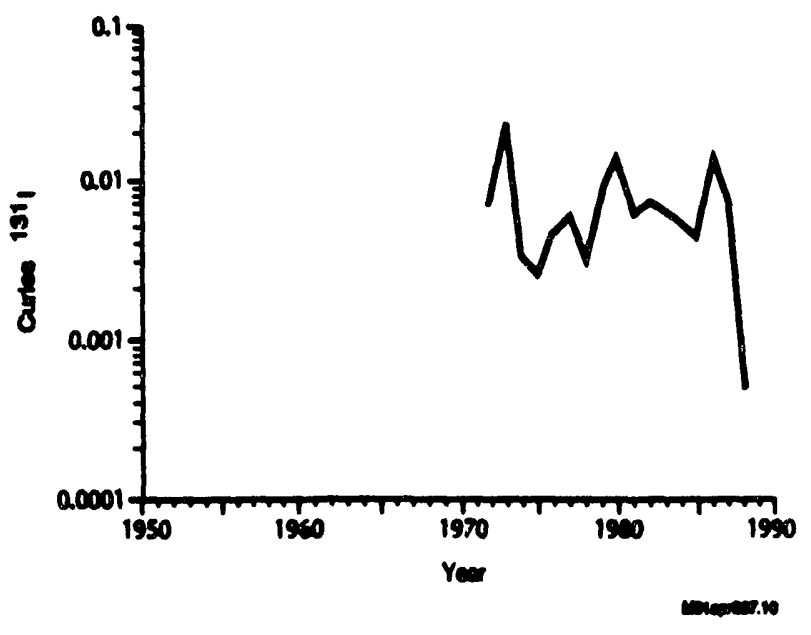

Fugare 3-12. Combined Measured Annual Atmospheric Relesses from Resctors

\section{Separations and Liquid Waste Facilities}

Two chemical separations facilities and their amocinted liquid waste storage facilitics are located near the center of the site (Figure 3-1). The two separations areas are identified by letter deaignations $\mathbf{F}$ and $\mathbf{H}$. In these facilities the products of interest in irrediated materials are chemically separted and purified from waste products; this procedure is callod reprocessing. The greateat releases of radioiodine to the environment a SRS originated from these facilitiea.

\section{Facility Operations}

The two chemical separations facilities reproceas irradiated fuel and targets in buildings known as canyon buildings. Irndiated materials are diseolved and the products of intereat are chemically separated and purified from waste fission and ectivation products.

Reprocessing began in late 1954 in F Area and mid 1955 in H Area. The Purex eolvent extraction process is used to recover $20 \mathrm{Pu}$ and $20 \mathrm{U}$ from waste products in irradiated 20U. During 1959-1960 the H-Area Purex process was modified to recover ${ }^{200} \mathrm{U}$ from the wate product in irradiated ${ }^{20} \mathrm{U}$ fuel using the HM (H Modified Purex) process. The principel chemical difference in the proceseses is that the HM process uses mercuric nitrate as a catalyst to enhance the dissolution of irradiated fuel.

Later modifications to both facilities allowed $201 \mathrm{~Np}$ to be recovered for use as target material. Imadiated $201 \mathrm{~Np}$ targets are dissolved and treated by the Frames ion exchnnge process in H Area to recover ${ }^{200} \mathrm{Pu}$ and ${ }^{20} \mathrm{~Np}$ from the waste products. H Area also includes the RBOF storage facility.
Waste facilities in or adjacent to the separations facilities were deaigned for liquid waste handling. Depending on ectivity level, liquid wastes are stored in waste tanks or sent either to soepage besins or to the Effluent Treatment Fecility (ETF) in H Area. In November 1988 the ETF became operational to treat the wastes that were previously sent to seepage basins. The seepage basins were then clowed and, as of 1989, were being docommissioned.

\section{Pathways for Release}

Unlike the reactor facilities, which have released ${ }^{131}$ I to the environment principally through aqueoas effluents, the separations facilitica have roleased ${ }^{131}$ I almoet oqually through atmoepheric and aqueous effluents. However, almoet all aqueous ${ }^{211}$ I releases from separations facilities were discharged to reepage basins and not directly to site atreame.

During the cheluical separations proceseces, radioiodine exists as a vapor, or is diseolved in aqueous and organic solvents. Emission controls minimize the atmoepheric 
release of radioiodine volatilized during diseolution of irradiated materisla. Volatilization of radioiodine also occurs in the separation and purification steps following diseolution. For example, the organic chemicals in these seps react with radioiodine to form volatile organic iodides. fi- leases then occur through the process vessel vent system, "wich exhaust to the atmosphere through a size-graded senct filter and a 61-m stack.

Volatile organic iodides that are expected to be present in atmospheric effluents include the alkyl iodides, such as methyl iodide or butyl iodide. Volatile inorganic forms may include $\mathrm{I}_{2} \mathrm{ICl}, \mathrm{IBr}, \mathrm{HI}$, and $\mathrm{HOI}$. Moreover, organic and inorganic forms of iodine may also be associated with particulate matter in the effluent (Brauer and Strebin, 1982).

Two studies examined the distribution of the organic and inorganic forms of iodine in air effluent from $H$ Canyon. Eighty to 90 percent of the iodine was present in the organic form (SRL, 1973a; SRL, 1973b).

In a preliminary study of organic forms of iodine in atmospheric effluents from the SRS Purex process, butyl iodide and ethyl iodide were identified among numerous organic components that were detected; the other components were not identifiable (Smith and Weat, 1967).

Two later studies quantitatively measured the distribution of organic iodine compounds in air from H-Canyon. In one study essentially all of the organic iodine was present as methyl iodide (SRL, 1973a). The second study found that butyl iodide was 5 times more prevalent than methyl iodide (SRL, 1973b).

The presence of butyl iodide was attributed to radiation-induced reactions in the tributyl phosphate extractant of the Purex process. A butyl group formed in this manner can react with iodine to form butyl iodide. The different results obtained in these limited studies may indicate that the composition of iodine in stack air is dependent on which step of the separations and purification processes is being performed.

Aqueous waste streams contain residual radioiodine. Highlevel and low-level aqueous wastes are stored in tanks after their volume is reduced in an evaporator. The condensate from the evaporator contains radioiodine because some of the radioiodine distills. The condensate was sent to the seepage basins prior to 1988. The condensate is now sent to ETF. Another example of aqueous waste are occasional leats in cooling water coils in process vessels.

The disposition of various process waters from the separations facilities depend on the results of analyses of the water for radioactivity. Water is concentrated in evaporators prior to storage, sent to seepage basins or to the ETF, temporarily retained in basins, or released to site streams.

The major sources of wastewater previously discharged to the scepage basins were the overbeads from the nitric acid recovery unit and the process evaporators in both F and $\mathrm{H}$ Areas. In $H$ Area, water from the Resin Regeneration Facility and RBOF was also discharged to the H-Area Seepage Basins. A flow sheet for liquid waste handling can be found in the reference Jacobsen et al., 1973. Because of the date of this reference, it does not show that ETF replaced the eeepage basins.

Even after organic waste streams from the solvent extraction process receive a caustic wash, the solvent may contain residual treces of radioiodine due to the propensity of iodine to react with organic sompounds. Spent organic solvent is sent to the SWDF for incineration. No studies of the radioiodine content of waste organic solvent have been performed.

\section{Emission Control}

Allowing sufficient time for ${ }^{131}$ I to docay to low levels prior to reprocessing reduce ${ }^{131}$ I releases. In the mid 1960 , the cooling time was lengthened from 100 to at least 200 days for moet irradiated materials.

Administrative and physical controls, which were implemented in reactor areas after the 1961 scute release incidenth minimize the possibility that very short-cooled fuel or targets might be inadvertently sent to the chemical separations areas.

The offgas from dissolution of irradiated materials is vented to the atmosphere through silver-nitrate-coated ceramic chipe (beryl saddles), an acid recovery unit, and a 61-m stack. Volatilized iodine reacts with the silver nitrate to form highly insoluble silver iodide on the chips. This emission control system, known as a silver-nitrate reactor, has been in place since the startup of the chemical separations facilities. In the Fromes process, offgases from the dissolution of 207 Np targets do not pass through the silver-nitrate resctor enroute to the stack. This is because fewer fissions occur in $207 \mathrm{~Np}$ than in uranium. The fewer fissions also allow ${ }^{27} \mathrm{~Np}$ targets to be cooled for less time than uranium.

Some residual radioiodine that continues through the chemical separations process is retained in the precipitate of manganese dioxide that is used to clarify the solution of irradiated material in preparation for solvent extraction. 
Some revidual radioiodine that continue through the proces is volatilized into the procens veasel vent syatem.

Offeases from the procese veseel vent system are exhausted through a and filter and then through the 61-m stack. Although the and filter is not expectod to efficiently retain iodine, it is expected to returd the movement of some forms of iodine, which are wocessively being adsorbed and deacobed on the and particles. The 61-m atack in each facility provides enficicient loft to the offereses to ensure that radioiodine is discipated into very low concentrations over a hrge area. This minimizes expoesure to people in and around the facility.

In the early years of operation, exhaus air was also paseed through a caustic scrubber in F and H Aress to trap iodine. Erratic performance of the scrubber units contributed to the elevated ${ }^{231}$ I releases observed in the initial years of operation.

The HM process has an inherent emiation control feature. The mercuric nitrate catalyst used in the diseolution step reacts with iodine to produce a nonvolatile form of iodine.

\section{Release Monitoring}

Atmospheric releases of ${ }^{1{ }^{1}} \mathrm{I}$ from separations facilitis have been quantified since shortly after startup in 1954. Reprocessing of irradiated material began in F Canyon in November 1954. The firt ampling period for ${ }^{131} \mathrm{I}$ in atmospheric effluents was December 14, 1954 to January 7, 1955. H Canyon began operations and ${ }^{21 I}$ release measurements in July 1955.

Continuous sampling of stack air for radioiodine is socomplished by pasaing a portion of the air through a filter that traps iodine. The air is extracted at the 59-m beight and passes through approximately 90 meters of piping to the filter aseembly at ground level. The filter is changed weekly and analyzed for radioiodine.

Limited studies of loseses of iodine due to adsorption on the piping interior surfaces have been conducted. Adsorption is principally aseociated with elemental iodine. This appens to be a minor conetituent of the chemical forms of iodine in stack air (SRL, 1973e; and SRL 1973b). Because adeorption is not well characterized for various operating conditions, no allowance for possible losses is made in quantification of the releasea.

Three different tochniques have been used to trap radioiodine. They represent the most suitable technologies that were available at the time. Initially, two different filters were usod in parallel to trap radioiodine; one was a filter paper coated with silver nitrate, and the other was a cauntic ccrubber. In the early 1960 s theare were repleced by two TEDA-impregnated charcoal cartridges in ceries.

The change to charcoal filters was prompted by the release of 153 curies of ${ }^{231} I$ from $F$ Area over a 26-day period in 1961 (Jolly at al, 1968). This scute release incident was due to the insdvertent reproceasing of very short-cooled matorial. As the time of the release, the silver-nitrate filter did not provide an sccurate measure of the severity of the release. The iodine collection efficiency of the silver-nitrate filter paper hed dropped from 82 percent to 32 percent. This docresee was attributed to unusual concentrations of nitrogea oxides and other chemicals in the stack air (Marter, 1963). The release was quantified with the caustic serubber syatem, which had a history of unreliable measurements because of erratic performance (Marter, 1963; Jolly of al., 1968).

The replecement chareoal filter system follows a filter paper that removes particulates. The firs charcoal filter contains a redintion monitor that is set to alarm at an inetantaneous release of approximately 0.3 curiea. The daily change in cumulative activity is aleo monitored to detect unusually large daily releases that are leas than the alarm point.

After a one-woek exposure, the filters are analyzed for ${ }^{131}$ I by gamma spectrometry and for 221 by low energy photon spectrometry. Typically, the radioiodine is distributed greater than 97 percent in the charcoal and leas than 3 percent in the particulate filter.

Since 1963 in F Area, diveolver offereses containing excess ammonia vapors have been diverted to an auxiliary $61-\mathrm{m}$ stack after pasaing through the silver-nitrate reactor. Various methods have been used to quantify releases from the auxiliary stack; a molecular sieve filter proved to be the mot effoctive. The filter is changed woekly and measured for ${ }^{231} \mathrm{l}$; it is not routinely measured for ${ }^{22} \mathrm{I}$.

Aqueous releases of ${ }^{131}$ I have been quantified since 1955. Several techniques are used to monitor aqueous releases. Process cooling water in F Area is monitored in-line for beta-gamma sctivity. In H Ares, batches of process cooling water are monitored prior to releave. When liquid effluents were released to seepage basins, they were continuously sampled. Samples were collectod weekly and analyzed by gamms spectrometry which detects ${ }^{131}$ but not ${ }^{221}$. Effluent Treatment Facility discharges are sampled and analyzed by gamms spectrometry prior to release to Upper Three Runs Creek. 


\section{History of Measured Releases}

The greateat aqueous and atmospheric releases ure typically aseocinted with the reproceasing of ahort-cooled fuel and targets, which occurrod in the late 1950 and early 1960 s. Short-cooled fuel and targets were reprocessed at that time because of the urgency to recover the special nuclear materials needed for nuclear weapons. In later years ${ }^{131}$ I relesses from separations areas were reduced as a result of a longer cooling period before reprocessing. Occasionally reprocessing of abort-cooled materials continued into the 1970 .

As the time of the greatest ${ }^{131}$ I releases, no mensurements of short-lived isotopes ach as ${ }^{159}$ and ${ }^{10}$ I were reported. These isotopes would have accompanied any ${ }^{131}$ I that was released if very short-cooled materials were reprocessed (Table 2-1, page 10).

Since the mid 1980s, atmospheric releases of ${ }^{120}$ I have been quantified by measurement; prior releases were quantified by calculation.

\section{F-Area Aqueous Releases}

Aqueous wastes from $F$ Canyon were initially sent to waste tanks and a seepage basin designated 904-49G, also known as Old F-Area Seepage Basin. The capacity of this basin proved to be inadequate. It was abandoned in 1955 after three additional seepage basins, (904-41G, $-42 \mathrm{G}$, and $-43 \mathrm{G}$ ) were constructed. These are known as $F$ Seepage Basins 1 , 2 and 3, and were used from 1955 until 1988 when waste waters were diverted to ETF; they are being dewatered and backfilled as of 1989.

The total measured aqueous release of ${ }^{131}$ I to the F-Area seepage basin system through 1988 is 903 curies. Measured annual releases of ${ }^{231} I$ are shown in Figure 3-13. The maximum annual release, 403 curries, occurred in 1956. This is attributed to the reprocessing of short-cooled materials. The increase during 1961 is associated with the acute release incident.

For ${ }^{12 \%}$, only estimates of releases to the seepage basins are available. The cumulative release is estimated at 2.0 curies for the F-Area seepage basins througb 1985 (Killian et al., 1985a). This estimate is consistent with an inventory estimate of 0.7 curies through 1987, which is based on a few measurements of ${ }^{129} I$ in basin water and basin sediments.

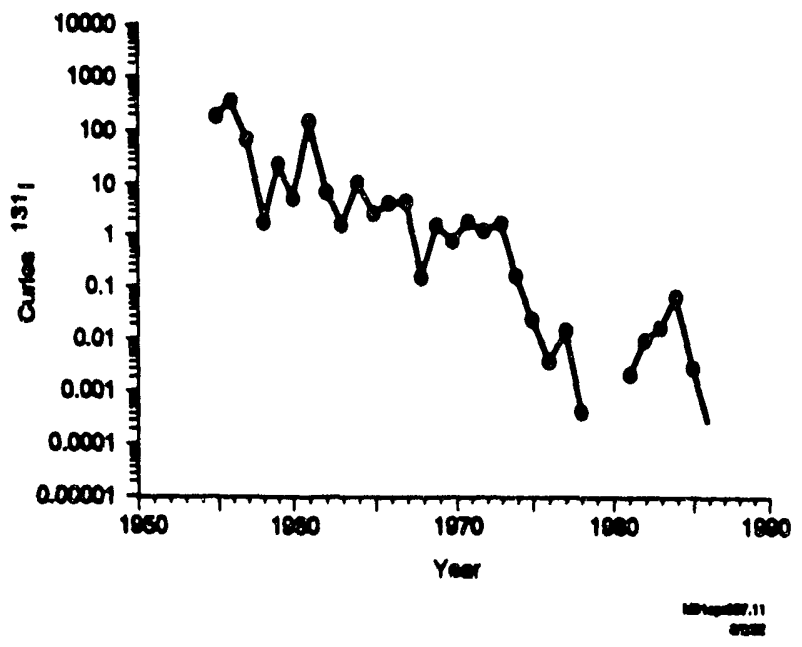

Frgure 3-13. Measured Annual Aqueous Releases of ${ }^{131}$ I to F-Area Seepage Basins

Various process waters that contain only low levels of radionctivity are discharged to Four Mile Creek. A limited study of the 120.1 content of the effluent was conducted in 1979 and 1980. Concentrations did not exceed $0.06 \mathrm{pCi} / \mathrm{h}$, which indicates the effluents are not a significant source of 1291 (Kantelo, 1987).

\section{F-Area Atmospheric Releases}

The total measured atmospheric release of ${ }^{131}$ I from F Area through 1989 is 1,112 curies. Measured annual releases of ${ }^{131}$ I are shown in Figure 3-14. The maximum annual release, 688 curies, occurred in 1956. During 1958 atmospheric releases of ${ }^{131}$ I were below minimum detection limits because F Canyon was shut down for modifications from March 1957 until March 1959.

SRS's only acute atmospheric ${ }^{131}$ I release incident due to the inadvertent reprocessing of very short-cooled material occurred in 1961 when 153 curies were released between May 29 and June 23 (Merter, 1963). About half of the ${ }^{131}$ I was released in the firs 5 days; the daily releases were 6, 24, 12,18 , and 14 curies. In comparison the average daily release during 1960 and 1961 (exclusive of this incident) was 0.02 curies. No measurements of ${ }^{12 \%} \mathrm{I}$ were performed in response to this incident. Because the reprocessed material had only a very short cooling time, the quantity of ${ }^{120} \mathrm{I}$ released was insignificant relative to the quantity of ${ }^{131}$ I released (Table 2-1, page 10). 


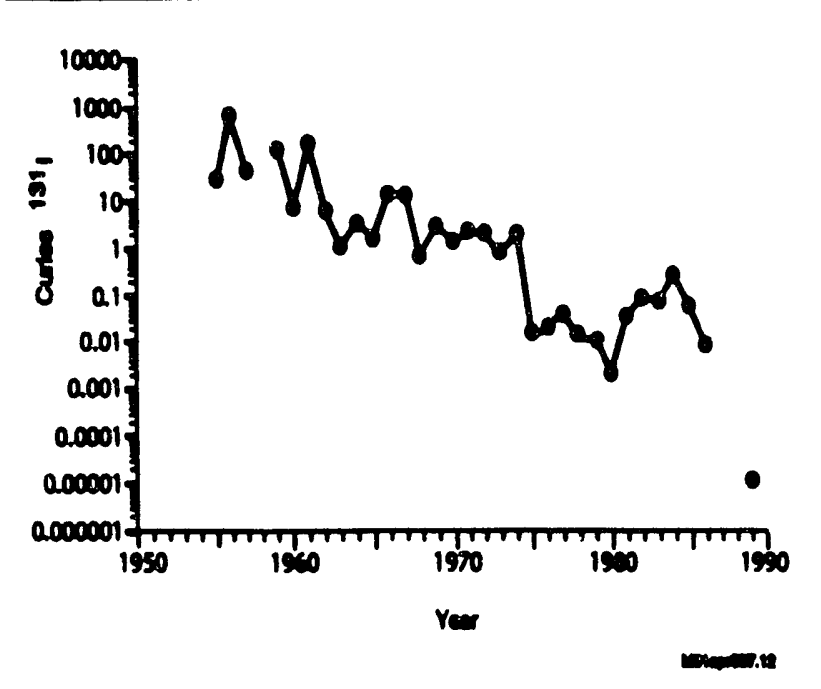

Frgare 3-14 Mrasured Annual Atmoepheric Roleases of isl I from F Area

A malfunction of the silver-nitrate reactor was reportod in the 1967 enviroumental report. A low colloction efficiency appareotly doveloped in the F-Area unit, which resultied in 8

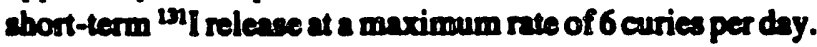

The history of annual atmoesperic releases of 201 from $P$ Canyon will be discused with H-Area atmoepheric releasea. Releases from the two areas have been historically published together as one combined annual release.

\section{H-Area Aqueous Releases}

Aqueous wastes from H Canyon were sent to waste tanks and four seepage basins (904-4G, -45G, -460 , and $-56 G$ ). The basine, which are aleo known as H Seepage Baxins 1,2, 3, and 4, were used from 1955 until 1988 when wate watere were diverted to ETF. Basin 3 wes not uned after 1962. All besins are being dewatered and backfilled es of 1989.

The total measured aqueous release of ${ }^{1 M_{I}}$ to the H-Area seepage basin system through 1988 is 1,711 curies. Measured annual releases are shown in Figure 3-15. The maximum annual release, 798 curier, cocurred in 1957. This is altributed to the reprocesaing of short-cooled materials.

For 201 only eatimates of releases to the seepage basins are available. The cumulative release is setimated at 0.4 curiea for the H-Area seepage basins through 1985 (Killian et al. 1985b). This extimate is consistent with an inventory catimate of 0.9 curies through 1987, which is based on a few measurements of ${ }^{12} \mathrm{I}$ in basin water and basin sediments.

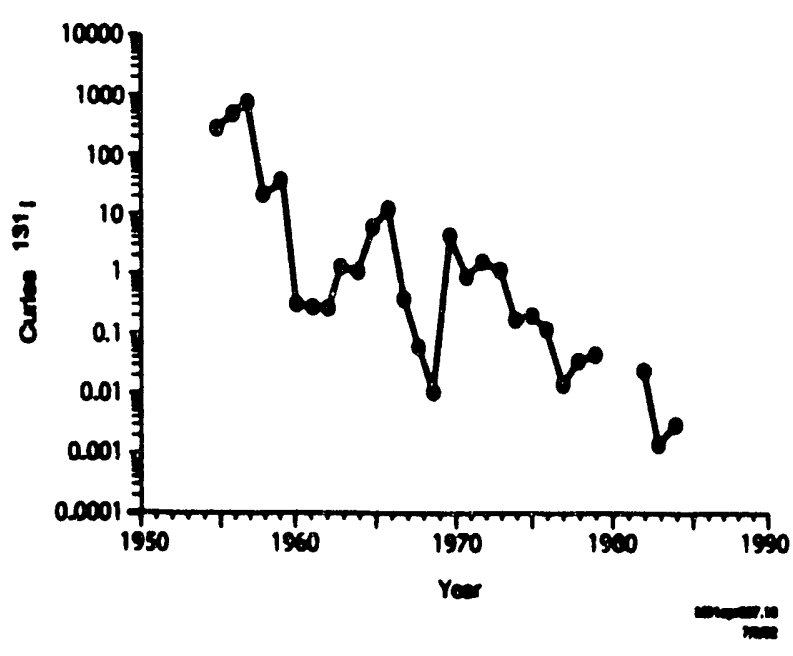

Dere 3-15. Measured Annual Aqueous Releases of ${ }^{131}$ I to H-Area Seepage Basins

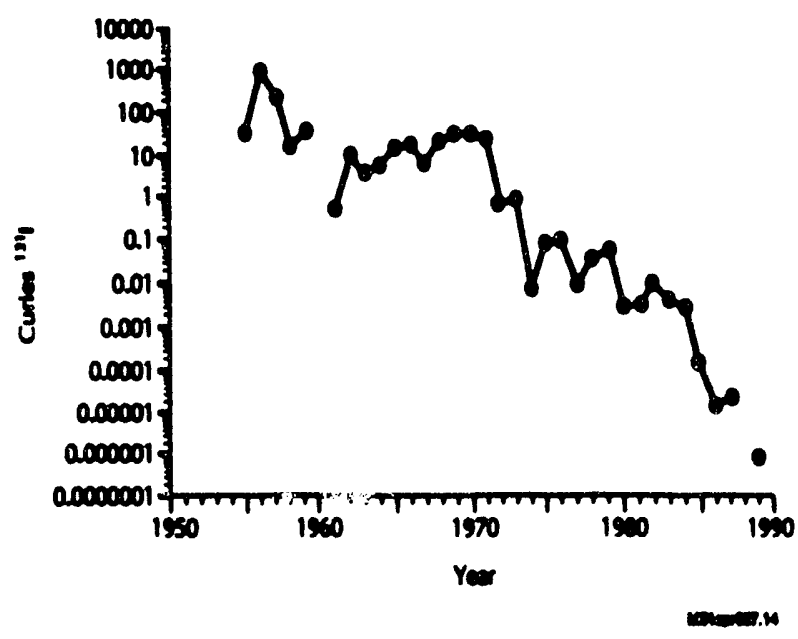

Doure 3-16. Measured Annual Atmospheric Releases of 'III from $H$ Area

\section{H-Area Atmospheric Releases}

The lotal measured atmoepheric release of ${ }^{131}$ I from $H$ Canyon and RBOF to the atmosphere through 1989 is 1,399 curiea. Enentislly all of the ${ }^{21} I$ originated in H Canyon. Measured anounl releaces are abown in Figure 3-16. The maximum annual release, 888 curies, occurred in 1956. During 1960 atmoepheric releases of ${ }^{11}$ I from H Area were below minimum detection limits because H Canyon was shut down from April 1959 until the end of 1960 for modifications to convert to the HM procese. 


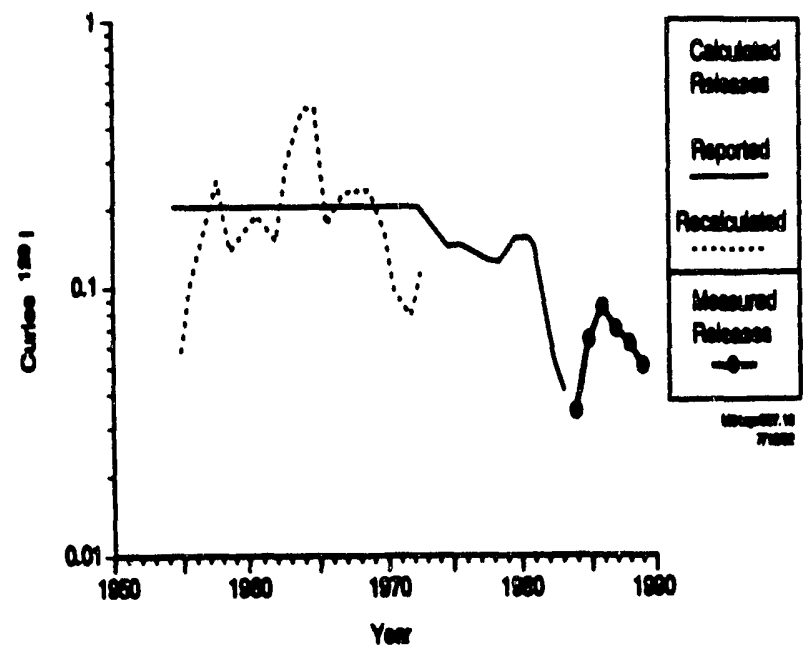

Figure 3-17. Combined Annual Atmospheric Releases of ${ }^{129}$ from Separations Areas

The annual atmospheric release of 201 from the two separations areas is historically published as a combined release. The total combined ${ }^{12 \%}$ atmospheric release through 1989 from F and H Areas is estimnted to be 5.7 curies. The eatimnte is based on calculated and measured annul releases as shown in Figure 3-17.

Prior to 1984, snnual ${ }^{129}$ releases were determined by calculation only. The calculation is based on the quantity, composition, and irrediation history of reprocessed materials; on the ${ }^{129} 1$ fission yield; and on the efficiency of iodine removal in the chemical separations processes. This efficiency is based on the experimentally measured distribution of ${ }^{131} I$ in various steps of the separations processes.

For 1955 through 1973, two types of calculated annual releases, reported and recalculated, are plotted in Figure 3-17. The reported releases were determined by calculating atmospheric ${ }^{12}$ I releases from the separations areas during 1955-1973 and prorating the total on an annual basis (Zeigler and Lawrimore, 1988). This method gives a constant value of 0.21 curies of 1201 released per year. Releases were recalculated to estimate the year-to-year variations in the combined releases for a study of ${ }^{129}$ deposition (Boone et al., 1985).

Measured relenses have been reported in the site release documents since 1984. From 1981, when measurements were begun, through 1983, calculated releases agreed satisfactorily with the messured releases. For example, in 1981 the measured release of 0.139 curies is 13 percent different from the calculated release of 0.160 curies.
The maximum recalculated ${ }^{20}$ relenses occurred in 1964 and 1965. These annual relenses of 0.5 curies are 2.5 times greater than the average release for 1955 through 1973. The maximum releases reflect the quantity, composition, and irradiation history of reprocesed materials at that time. The decrense from approximately 0.15 curies in 1981 to 0.06 curies in 1982 reflects a change in irradiation conditions. The change required targets to be irradiated to only half of their previous expowure; correspondingly, the quantity of ${ }^{12} 1$ produced is approximately half of the previous quantitien.

\section{Effluent Treatment Facility}

Aqueous discharges are analyzed for ${ }^{131}$ I by gamma spectrometry. No ${ }^{131}$ I has been detected. No analyses for ${ }^{120}$ I have been performed as of 1989.

Stack air was tested for compliance with National Emincion Standard for Hazardow Air Pollutants during anrtup teating in December 1988 and January 1989, when ETR was operating at about 30 percent of capacity. Stack air was continuously ampled for redioiodine using a particulate filter followed by two TEDA-impregnated churcol filter in series. The filters were changed weekly and andyzed for 13I I by gamma spectrometry and for 120 by low energy photon spectrometry. Although no ${ }^{131}$ I was detected, low levels of ${ }^{129}$ were detected (Taylor, 1989). By scaling the 12T release to an annual basis and to 100 percent of operating capacity, an annunl relense of approximntely 0.0002 curice of 121 is estimated. This is less than 1 percent of the combined atmospheric release of ${ }^{12} 1$ from $F$ and $H$ Canyons for 1989.

\section{Waste Tank Farms}

High level radiosctive liquid waste storage tanks, located in both F and H Areas, contrin ${ }^{221}$. Approximately 40 percent of the SRS-produced ${ }^{229}$ Is of 1974 is predicted to have been disposed of in the waste tanks (Comman, 1974).

The waste in the trinks consists of sludge and supernates; jodine is expected to be in the supernate rather than the sludge. Limited andyses for the ${ }^{121}$ content of the sludge and supernate in certain waste tanks have been performed. Samples of decontaminated supernate from F-Area Tank 24 were analyzed in 1983. No ${ }^{121} 1$ was detectable at a detection limit of $450 \mathrm{pCi} / \mathrm{L}$ (Ryan, 1983). 
Sudies of enperente is H-Aren wate turb show 129 concentrations on the ondat of $10^{8}$ pCIL for Tanto $11 \mathrm{H}$, 12H, 15H, and 32H (Rowler and Cook, 1984). No 291 was detectable in sludge anmples from Tanke 9H, 10H, 13H and $15 \mathrm{H}$ at a detection limit of $5 \mathrm{pCi} / \mathrm{g}$ (Fowler and Cook, 1984). Based on these ctudies, Fowler and Cook actimated that the inventory of 201 in SRS waste tanks, as of the early 1980s, was 9.1 curies.

Rediosctivity leaked into the ground from certain waste tunke. In 1960, H-Aree Tank 16 leaked about 100 liters of whete into the currounding coil (Poe, 1974), In 1961 F-Area Tank 8 leaked about 6000 liters of wate onto the soil (Odum, 1976). The reported inventory of redionuclides for these tunto did not include ${ }^{2}$; contaminated soil was not andyzed for 1 .

Waste tanls have the potential to release radioiodine to the atmoxphere. Because the vapor space in the waste tunks is flushed with eir, volatile forms of radioiodine are relessed to the atmosphere. Vented air from the tantos is not monitored for radiojodine.

\section{Summary of Separations and Liquid Waste Facilities}

Total squeous releases of ${ }^{231}$ to seepage busins from separation facilities are nearly equal to the total atmospheric relenses. The total mensured ${ }^{211}$ I releases through 1989 are 2,614 and 2,511 curies to seepage basins and the atmosphere, respectively. For ${ }^{21}$ the correspondis estimated releases are 3 and 6 curies. (Nine curies of ${ }^{12} 1$ are eatimated to be atored in waste tanks.) The distribution of 129 between basins and the atmosphere differs from the distribution of ${ }^{231}$. This is likely due to the considerable uncertninty in the eatimate for the ${ }^{129} 1$ inventory in the bersins.

The combined anoul releases of radioiodine from separntione areas to the atmosphere and the seepage basing are shown in Figure 3-18. This includes the annual atmocpheric relenses of 221 ming the recalculated values for 1955 through 1973. The long-term trend is that ${ }^{131}$ I relenses decressed significantly with time following the maximum releases in the early years of operation. Annual releases in the 1980 were approximately 0.01 percent of the relenses in the lite 1950. In peoerd since 1975, ${ }^{131}$ I releases to the atmoaphere have been less than ${ }^{120}$ I releases.

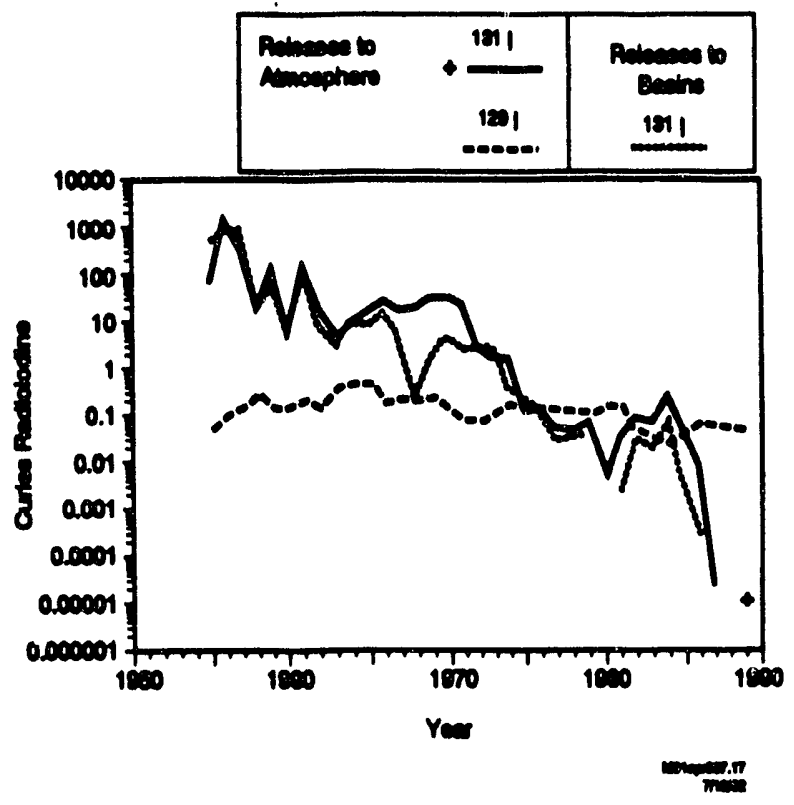

Noure 3-18. Combined Annual Relesses of Redioiodine from Separations Areas 


\section{Solid Waste Disposal Facility}

The SWDF is a site for burial or above-ground atorage of radionctive solid wastes and certnin liquid wasten. The firs facility, designated 643-G, was used from 1952 to 1972. The now facility, deaignuted 643-7G, is adjecent to the original and has been used since 1969.

The predominant radioiodine-containing material buried at SWDF is the epent ceramic chips conted with silver nitsate that were used for emiasion control during the dissolution of fuel and targets in F and $\mathrm{H}$ Areas. The buried inventory of 121, as of 1982, is extimated to be 14 curies (Hawking, 1983). The prectice of burying epent chips was terminated in the early 1980. They are now storsod at SWDF withcut burial.

Other solid waste buried at the SWDF is potentially contuminated with ${ }^{12} 1$ (for example, spent resctor deionizers). No andyses of these materials for ${ }^{22}$ I content have leen performed.
Liquid waste that potentially contains radiojodine has been stored at the SWDF. Degradod solvent from the separations areas was burned in open pans at the SWDF in the early years of operntion. Since 1975 it has been stored in teel tanks at the SWDF pending combustion in an incinerator for radiosctive waste. As of 1987, 655 of the 755 cubic meters of degredod solvent stored in the tanks since 1975 had been incinernted (Jagge et al., 1987). Given the propensity of iodine to react with organic compounds, the degraded solvent may contain ${ }^{22} 1$, even though the solvent has been scrubbed with cautic. No 221 analyses of the spent solvent have been performed.

\section{Savannah River Laboratory}

SRL provides research and development support for the production facilities of SRS. Laboratory facilities handle radiosctivity ranging from high levels, which are manipulated in shielded cells, to environmental levels.

Certain liquid radionctive wastes are sccumulated in bolding tanks pending shipment to $\mathrm{F}$ Area for treatment and disposition. From 1954 to 1982 , a seepage basin system was used for low activity wastes. The first two seepage basins (both designated 904-53G) were pleced into service in 1954. The last two beain (904-54G, and -55G) were added in 1958 and 1960. No radioiodine is documented as having been released to the SRL seepage basins.

Experimental studies using high levels of radionctivity have been performed in shielded cells. Air vented from the shielded cells pasees through a carbon bed to remove iodine, then through HEPA filter before exhauting through a 50 -m stack. In the early years of operntion a caustic scrubber was also used to purify air from the shielded cells. Before the air is discharged to the stack, it passes through a sand filter, wtich was installed in the early 1970 .

Air exhnusted from other parts of the laboratory passes through HEPA filters and exhausts through $30 \mathrm{~m}$ stacks. If air rediosctivity exceeds specific limits, the air is diverted to the and filter before being exhausted through the atack. All atack air is monitored for redioiodine using TEDA-impregmited charcoal filters. The offons exhaus from the SRL liquid stornge facility is aleo monitored for "13I using TEDA-impregnated charcoal filters.

The total measured atmospheric releases of ${ }^{231}$ I from SRL through 1989 is 6.4 curies. Measured annual atmospheric releases of ${ }^{131} \mathrm{I}$ are shown in Figure 3-19. The maximum annual relesse, 2.9 curies, occurred in 1958 when experimental studies of short-cooled fuel elements were performed.

Figure 3-19 also shows that 0.010 curies of ${ }^{13} 1$ were relensed to the atmosphere from SRL in 1973. This was the only documented release of short-lived ${ }^{133}$ I at SRS (Zeigler and Lawrimore, 1988; Cummins et al., 1991). The origin of the ${ }^{133}$ I is undocumented. If it originated from a sbort-cooled target or fuel element, ${ }^{12} \mathrm{I}$ might also have been present in the release. The presence of ${ }^{132} 1$ depends on when the iodine was chemically separated from telluriurs (Table 2-1, page 10). 


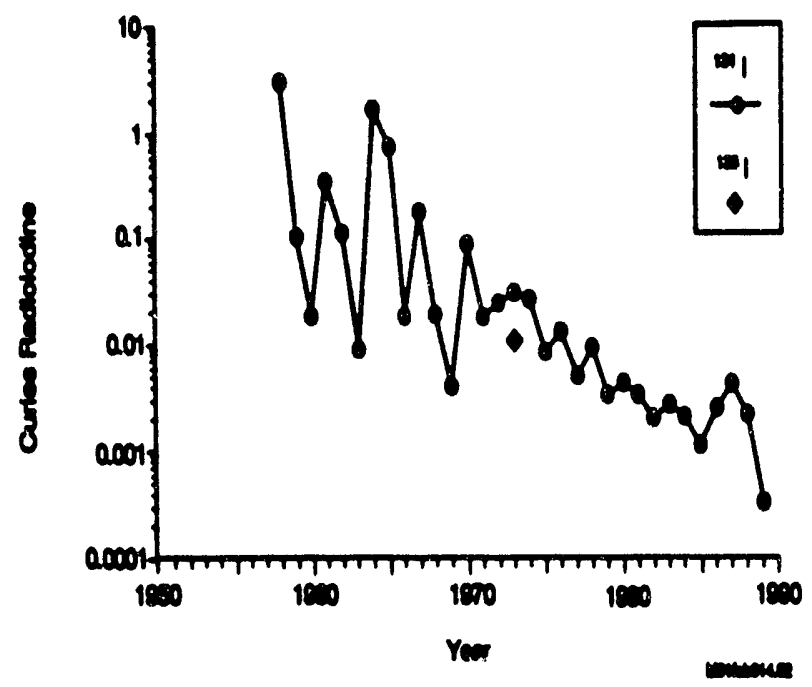

Thare 3-19. Measured Annual Atmoupheric Releseses of Radioiodine from SRL

\section{Other Facilities}

All documented ndioiodine releases from SRS facilities are listod in the previous sections. A number of other facilities handle materials containing radioiodine. The facilitice that have or had the potential to release ndioiodine are the teat reactors, the Heavy Water Rework Fecility, and any facility tandling spontaneously fimioning dements.

No releases of radioiodine are documented for any of the teat reactore described in Chapter 2. Had there been releasea from these fincilities, the releases would be amall compared to the releases from production reaciors. Operation of the teat reactors was discontinued by the 1970 .

The Heavy Water Rework Facility, located in D Area, consists of dietillation towers and aneociated equipment for removal of ordinary water that sccumulates in the heavy water moderator used in the reactors. Leals in the system are vented through \& 21-meter atack. The squeous waste stream is sent to Beaver Dam Creek after verification that setivity levels do not exceed specific limits. There is a potential for traces of radioiodine to be present in the moderator, as is described in the section on reactor facilities. No specific monitoring for redioiodine has been performed.
The prodominant radionctivity aseociated with this facility is tritium.

Facilities, other than those already deacribed in this chapter, that have handled spontaneoualy-ficioning elements are the reector material facilities in M Ares, (where uranium fuel and targets are fabricated), the TNX Semi Works (where various proceseces are teated on a pilot scale with uranium), and the Naval Fuels facility (where uranium fuel for the US Navy was fabricated from the late 1980 s until shutdown in 1989). The presence of low levels of radioiodine due to apontaneous fiasion thes no impact on operations at those fecilities because the redioiodine is contrined within the uranium metal; radioiodine in this case is only of scademic intereet. 


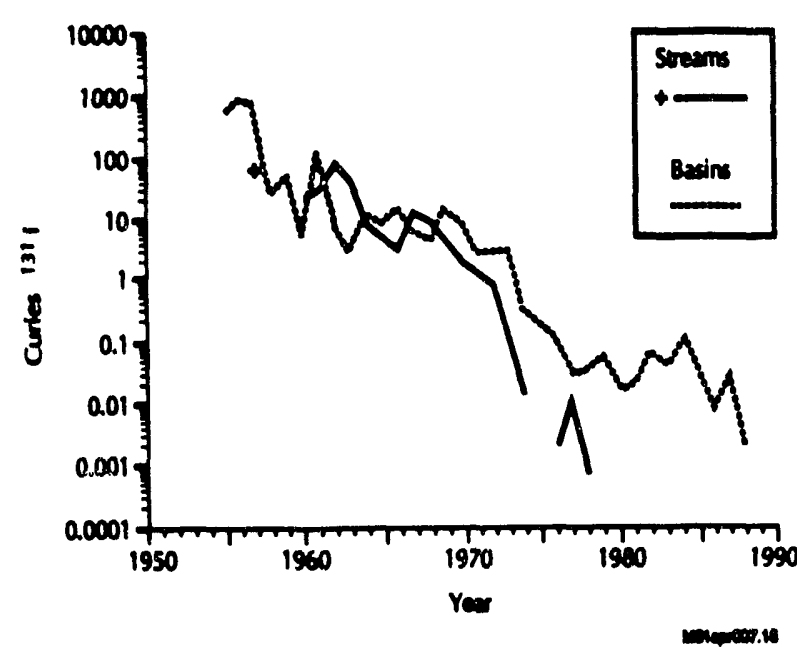

Figure 3-20. Combined Annual Aqueous Releases of 131 I from SRS

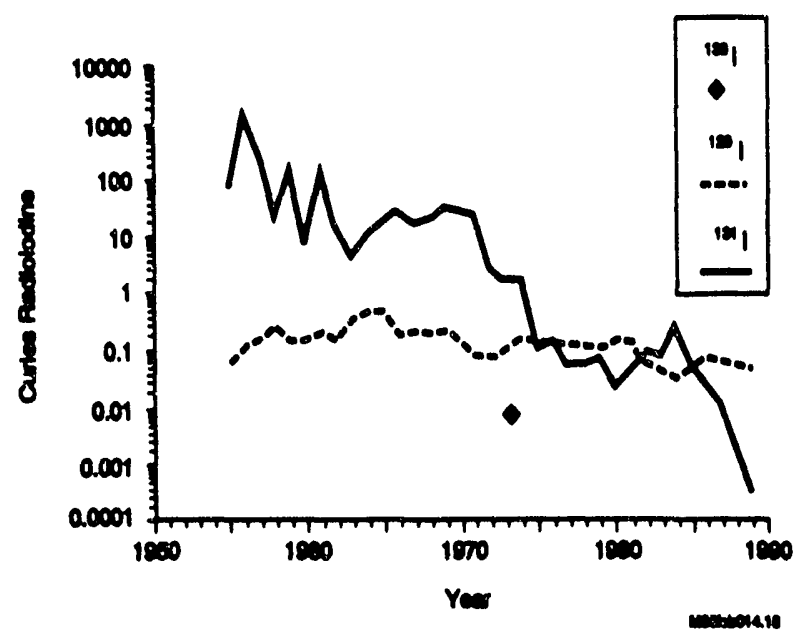

Figure 3-21. Combined Annual Atmospheric Releases of Radioiodine from SRS

\section{Summary of Measured Releases from SRS}

Measured annual releases of ${ }^{131}$ I from SRS to the aqueous environment are summarized in Figure 3-20. Annual releases of radioiodine from SRS to the atmospheric environment are summarized in Figure 3-21. In general, since 1975, ${ }^{12}$ T has been the predominant component of annual radioiodive releases to the atmosphere from the site. The annual aqueous and atmospheric releases of ${ }^{131} \mathrm{I}$ and ${ }^{129} \mathrm{I}$ are presented in tubular form in Chapter 5.

By the 1980 s the annual ${ }^{231}$ I releasee had been reduced to approximately 0.01 percent of the releases of the late 1950 . However, reductions in releases began by the early 1960 . Consequently, releases from 1963-1989 account for only approximately 8 percent of the total atmospheric ${ }^{131} I$. Ninety-two percent was released during the 8-year period from1955-1962.

The total releases of ${ }^{131}$ to the aqueous and atmospheric environments through 1989 are summarized in Table 3-1. Releases from the separations areas sccount for 89 percent of the total aqueous releases and greater than 99 percent of the total atmospheric releases. The separations areas discharged ${ }^{131} 1$ almost equally to seepage basins and the atmosphere. Reactor areas discharged ${ }^{131}$ I almoat exclusively to the aqueous environment. Direct discharges from reactor areas to site streams account for 10 percent of the total aqueous release from the site; direct discharges to streams ceased in 1978.

The purpose of the seepage basins is to allow short-lived radionuclides to decay to low levels during the time required (years) for the aqueous migration to site streams. An unknown portion of the radioiodine in the seepage basins volatilized to the atmosphere.

The beat estimate of the status of 1201 releases and inventories resulting from reprocessing through the mid-1980s is 3 curies to seepage basins, 6 curies to the atmoaphere, 9 curies stored in waste tanks, and 14 curies buried in the SWDF. Table 3-2 compares this distribution with the eatimated 1974 diatribution (Cornmen, 1974). Both extimation methodes show that approximately 70 percent of 1201 is stored and 30 percent is released to the aqueous and atmospheric environment. 
Table 3-1. Summary of radioiodine releaces (curies) to the environment through 1989

\begin{tabular}{|c|c|c|c|c|c|}
\hline \multirow[b]{2}{*}{ SRS Aren } & \multicolumn{2}{|c|}{ Aqueons } & \multicolumn{3}{|c|}{ Atmoapherie } \\
\hline & BrII & $m$ & "III & $m$ & $m$ \\
\hline $\begin{array}{l}\text { Separations } \\
\text { to benio } \\
\text { to atmoephere }\end{array}$ & 2614 & -3 & $\overline{2511}$ & $\overline{5.7}$ & $\bar{Z}$ \\
\hline $\begin{array}{l}\text { Reactore } \\
\text { to besin } \\
\text { to atreams } \\
\text { to atmosphese }\end{array}$ & $\begin{array}{r}24 \\
303 \\
\end{array}$ & - & $\overline{0.13}$ & 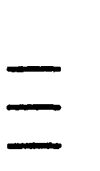 & $\overline{-}$ \\
\hline $\begin{array}{l}\text { SRL } \\
\text { to atmosphere }\end{array}$ & - & - & 6.4 & - & 0.01 \\
\hline Totals & 2941 & 3 & 2518 & 5.7 & 0.01 \\
\hline
\end{tabular}

Table 3-2. Comparison of the disponition of 121 in 1974 and the mid-1980

\begin{tabular}{|c|c|c|}
\hline \multirow[b]{2}{*}{ Dlopoalition } & \multicolumn{2}{|c|}{$\begin{array}{l}\text { Botlmated Perceant } \\
\text { Dletribution as of }\end{array}$} \\
\hline & mid-1980 & 194 \\
\hline SWDF & 4 & 30 \\
\hline Wate Tanbs & 28 & 40 \\
\hline Atmosphere & 19 & 20 \\
\hline Seepage Basins & 9 & 10 \\
\hline
\end{tabular}




\section{References for Chapter 3}

Booae, F. W, M. V. Kantelo, P. G. Mayer, and J. M. Palms, 1985, "Reaidence Haif-Times of ${ }^{201}$ in Undisturbed Surface Soils Based on Measured Soil Concentration Profiles", Health Physics 48, 401.

Bruer, F. P. and R. S. Strebin, Jr., 1982, "Environmental Concentration and Migration of ${ }^{12} \mathrm{~T}^{n}$, (IAEASM-257/43), in: "Environmental Migration of LongLived Radionuclides", LAEA STUPUB/597, Internationd Atomic Energy Agency, Vienna, p 465.

Cornman, W. R., 1974, "Estimation of ${ }^{229}$ Distribution in SRP Separntions Processes", DPST-74-533, E. I. du Pont de Nemoure and Company, Aiken, SC.

Cummings, C. L., C. S. Hetrick, and D. K. Martin, 1991, "Radionctive Releases at the Savannah River Site 1954-1989", WSRC-RP-91-684, Westinghouse Savannah River Company, Aiken, SC.

Fowler, J.R. and J.R. Cook, 1984, "I-129 in SRP High-Level Waste and Saltstone", DPST-84-343, E.I. du Pont de Nemours and Company, Aiken, SC.

Hawkins, R.H., 1983, "Mobility of ${ }^{129}$ in Buried Waste", DPST-83-590, E.I. du Pont de Nemours and Company, Aiken, SC.

Jecobsen, W. R, W. L. Marter, D. A. Orth, and C. P. Rose, 1973, "Control and Treatment of Radionctive Liquid Waste Rffluents at the Savannah River Plant", DP-1349, E. I. du Pont de Nemours and Company, Aiken, SC.

Jaegge, W. J., N. L Kolb, B. B. Looney, I. W. Marine, O. A. Towler, and J. R. Cook, 1987, “Environmental Information Document, Radiosctive Waste Burial Grounds", DPST-85-694, E. I. du Pont de Nemours and Company, Aiken, SC.

Jolly, L., Jr., J. A. Herper, and S. R. Smith, 1968, "Experience with an Improved Stack Monitor", Health Physics 15, 251.

Kentelo, M. V., 1987, "Summary of I-129 Messurements in Ground and Surface Water", DPST-87-820, E. I. du Pont de Nemours and Company, Aiken, SC.
Killian, T. H., N. L. Kolb, P. Corbo, and I. W. Marine, 1985a, "Environmental Information DocumentF-Area Seepage Basins", DPST-85-704, E. I. du Pont de Nemours and Company, Aiken, SC.

Killian, T. H., N. L. Kolb, P. Corbo, and I. W. Marine, 1985b, "Environmental Information DocumentH-Area Seepage Besins", DPST-85-706, E. I. du Pont de Nemours and Company, Aiken, SC.

Merter, W. L, 1963, "Radioiodine Relense Incident at the Savannah River Plant", Health Physics 9, 1105.

Odum, J. V., 1976, "Soil Contamination Adjacent to Waste Tank 8", DPSPU-76-11-4, E. I. du Pont de Nemours and Company, Aiken, SC.

Poe, W. L, 1974, "Leakage from Waste Tank 16", DP-1358, E. I. du Pont de Nemours and Company, Aiken, SC.

Ryan, J.P., 1983, The Analysis of Decontaminated Defense Waste Salt Supernate for I-129", DPST-83-325, E.I. du Pont de Nemours and Company, Aiken, SC.

Smith, S.R. and D.L. Weat, 1967, "Determination of Volatile Compounds of Fission-Product Iodine", Nuclear Applications 3, 43.

SRL, 1973a, March Monthly Report, Savannah River Laboratory, DP-73-1-3 Excerpt, E.I. du Pont de Nemours and Company, Aiken, SC.

SRI, 1973b, October Monthly Report, Savannah River Laboratory, DP-73-1-10 Excerpt, E.I. du Pont de Nemours and Company, Aiken, SC.

Taylor, R.W., 1989, "Effluent Treatment Facility Emissions Monitoring", DPST-89-309, E.I. du Pont de Nemours and Company, Aiken, SC.

Zeigler, C. C. and I. B. Lawrimore, 1988, "Releases of Radionctivity at the Savannah River Plant", DPSPU-86-25-1, Rev 6/1/88, E. I. du Pont de Nemours and Company, Aiken, SC. 
- 
Releases from SRS and global fallout from atmaspheric nuclear weapons tests have been the principal sources of radioiodine in the environment surrounding SRS. Beginning in 1954 SRS routinely anabyzed envinonmental samples for 131. Although routine aralyses of '"I did not begin until the mid 1980s, shortterm studies of its distribution in the environment have been conducted since the early 1970s.

Results of routine analyses are taken from periodic SRS environmental reports (see Bibliography). Typically, annual average values are used in this report. Results for short-ierm studies are taken from other reports published at SRS or in the scientific literature. The routine anablyses and short-term studies were designed to determine the fate of radioiodine as it moved through the environment by atmospheric and aqueous transport mechanisms. 


\section{Atmospheric Transport}

As a plume containing radiojodine moves through the atmosphere, the concentration of radioiodine in the air geverally decreases with distance from the source. This decrease is the recult of dilution and deposition.

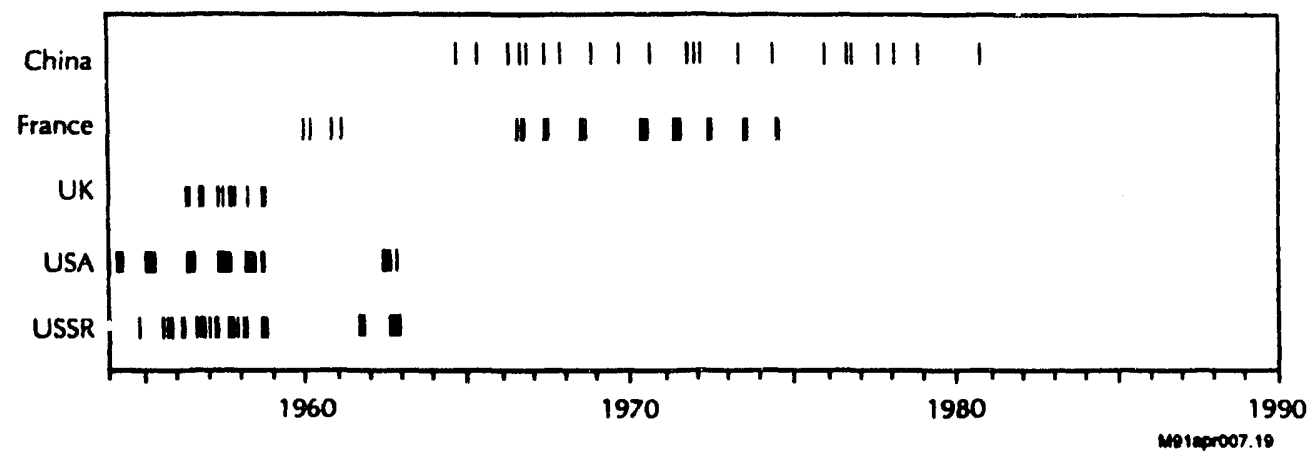

Fignre 4-1. The Occurrence of Nuclear Weapons Teets in the Atmoephere from 1954 through 1989

Dilution occurs as the plume spreads throughout an ever incresaing volume of air. The degree of dilution depends on such conditions as wind speed, turbulence, air buoyancy, and the height of the surface mixing layer. Under ideal conditions the decrease in concentration will be invernely proportional to distance from the release point. Over the course of a year, the inverse relationehip applies to annual average concentrations along the circumference at given radial distances from the release point.

The inverce relationahip is used in this report to distinguish SRS from global fallout as the principal source of redioiodine in the offeite local environment. This is determined by the alope of the straight line drawn through

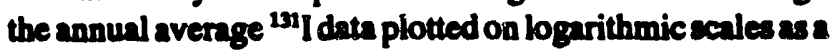
function of distance from the center of the separations areas at SRS. Distances are measured from this point, rather than the geographic center of the site, because atmospheric releases originate almoet exclusively in the separations greas. If globel fallout is the sole source of the radioiodine, the slope is 0 . Local concentrations do not change with distance from SRS because the fallout originates thousands of kilometers from SRS. If SRS is the sole source, the slope is -1 under ideal dilution conditions. On logarithmicscalesa slope of -1 means that concentration is halved for every doubling of distance.

When deposition is considered, the slope will be steeper (more negative) than the slope under ideal dilution conditions. Deposition consiets of physical and chemical procesess that remove radioiodine from the air and deposit it on the earth's aurface. These include gravity settling of particulate forms of jodine, entrainment with min, and physical and chemical interactions of iodine with vegetation, soil, and other features of the carth's aurface.
The eaviroament near SRS routinely contained detectable lovels of ${ }^{111}$ I from 1955 through 1962. Nuclear weapons teating in the atmoephore was intense during that time, and SRS releanes of ${ }^{31} I$ to the atmoephere were the greatcent in its history. Ninety-two percent of the total atmospheric ${ }^{131}$ releaned from SRS and 72 percent of the lotal ${ }^{131}$ I produced in atmospheric nuclear weapons teats occurrod from 1955 through 1962. (Seventy-two percent of the total fiesion energy yield produced in the history of worldwide atmonpheric teots occurrod during 1955 through 1962 [UNSCEAR, 1982].)

Figure 4-1 shows the frequency of worldwide nuclear weapons teats in the atmoephere from 1954 through 1989. Eartier atmoepheric tests are not included because the ${ }^{131}$ I produced in those teats docayed to imaignificant levels before meanurements began at SRS. This figure is based on tabulations of nuclear weapons teats (Benneth, 1978; Carter and Moghina, 1977; Perkins and Thomes, 1980).

As a reault of the Limited Teat Ban Treaty, the US, UK, and USSR ceased atmoepheric teating at the end of 1962. Residual ${ }^{131}$ I was not detectable in the environment after 1963. However, ${ }^{131} I$ was intermittently reintroduced to the environmeat due to atmospheric teating of nuclear weapons by China and Franco-two nations that did not participate in the treaty. No nation has teated nuclear weapons in the atmosphere since 1980.

Fallout from all but three of the Chinese atmospheric teats was detected in the vicinity of SRS. Fallout from the French teats after 1962 was generally not detected near SRS because these teats were conducted in the South Pacific and there is litule mixing of fallout from the southern bemisphere to the northern hemisphere. 


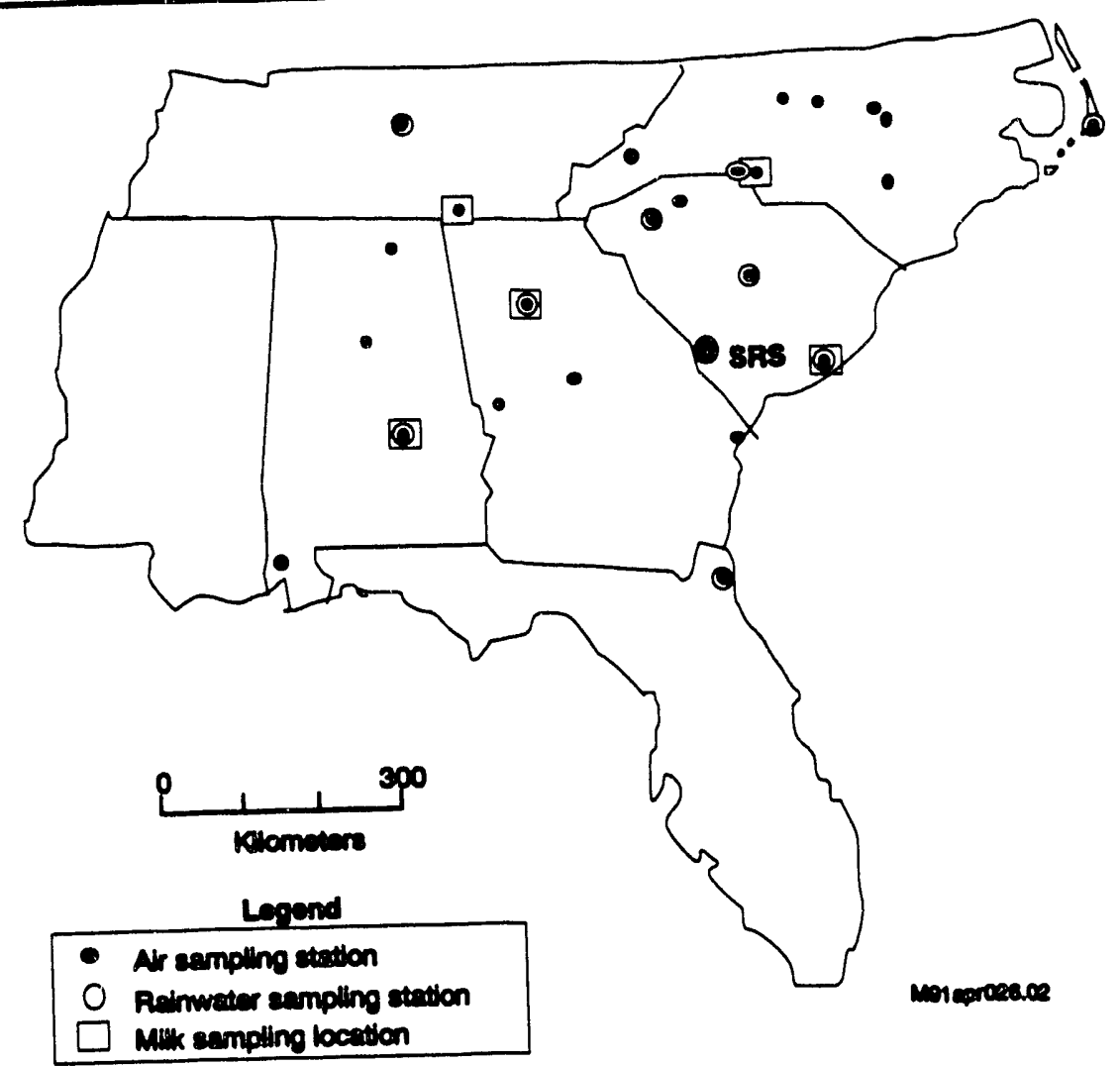

Fugure 42. Location of PHS Network Sampling Stations in the Southeast

To asseas the environmental impact of global fallout in the United States, the US Public Health Service (PHS) etablished several nationwide networks to collect and analyze environmental samples for radiosctivity. Data from the PHS networks are compared in this chapter with the SRS ${ }^{131}$ measurements. Figure 4-2 shows the locations of the network sampling stations that are used for the comparison. Only stations located in the southeast are used and most are located in major population centers.

Air and rainwater stations belonged to the National Air Sampling Network and the Environmental Radiation Ambient Monitoring System (the latter was known as the Radiation Surveillance Network from inception until 1967 and then as the Radiation Alert Network until 1974). Milk locations belonged to the Raw Milk Network and the Pasteurized Mill Network. In 1971 the PHS networks that were still operating became the responsibility of the EPA.

Because of incomplete mixing of weapons test debris in the atmosphere, fallout levels often widely varied between nearby locations. Such variations in network data have been minimized by averaging the data from the large number of locations in Figure 4-2. This provides a comprebensive southeastern value for comparison with SRS measurements of ${ }^{131}$ in air, rain, vegetation, and milk in the local environment.

\section{Air}

Beginning in 1955 SRS ampled the air for volatile and particulate forms of ${ }^{131} 1$ at locations onsite, near the site perimeter, and near the 40-km radius from the geographic center of the site. (In SRS terminology, 40-km radius means the circumference at a radius of $40 \mathrm{~km}$.) Four air sampling stations near the $160-\mathrm{km}$ redius were added in 1962 to provide distant background locations for measurement of globel fallout. The beckground stations happen to be located in cities that are part of the nationwide air sampling networks.

In moex years ${ }^{131}$ I has been detected at locations close to the separations areas. Near the perimeter and 40-km radius, ${ }^{331}$ was detocted from 1955 through 1963 . Near the $160-\mathrm{km}$ radius, it was detected only in the first two years of Operation-1962 and 1963.

No ${ }^{131}$ has been detected on an annual average besis since 1963 at any offsite location. The samples from the $40-\mathrm{km}$ 
radius typically were not measured from 1964-1980 unless 131 was detected at the site perimeter. No ${ }^{131}$ reaults were published in SRS eaviroamental reports from 1974 to 1979 and 1982 to 1986.

Figure 43 illuetrates the slope analyais tochnique to determine when SRS wes the principal source of radioiodine in the local offerite atmospheric environment. Annual average 131 I concentrations at individual sampling stations for two representative years are plotted apainat distance. The plotted distance is measured from the center of the two chemical separations areas rather then the geographic center of the sise because greater than 99 percent of the atmor pheric releases of radioiodine originates from the chemical separations areas.

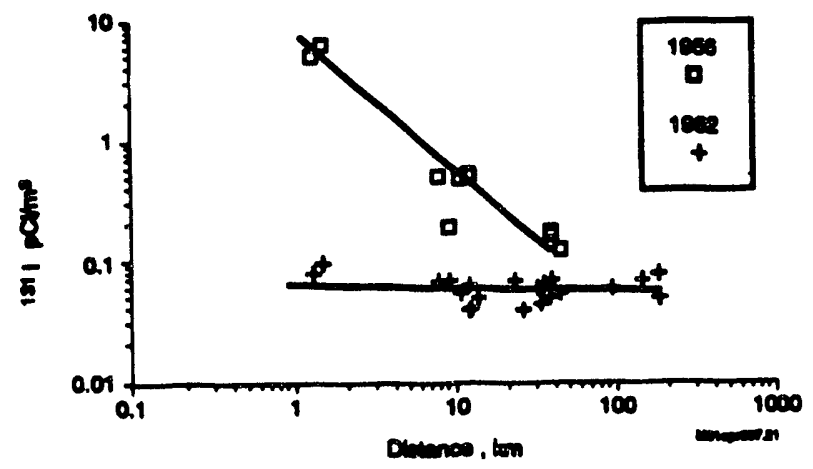

Frgure 4-3. Variation in Annual Average Concentrations of ${ }^{131}$ in Air with Distance from the Center of the Chemical Separations Areas at SRS for Two Representative Years

The results for 1962 illustrate a year in which SRS relenses had no influence on atmospheric ${ }^{331}$ at offiste locations. The slope of the regression line through the dat is -0.06 . Although concentrations decreased between locations near the separations facilities and site perimeter, they did not decrease between locations near the site perimeter and the $160-\mathrm{km}$ radius. Therefore, before the SRS ${ }^{131} 1$ reached the site boundary, it was overwhelmed by global fallout ${ }^{~}{ }^{31}$.

The reaults for 1956 abow that SRS was the principal source of atmospheric ${ }^{131}$ in the vicinity of SRS. The slope of the regreasion line through the data is approximately -1.1 . The lack of a background component demonstrates that SRS ${ }^{131}$ overwhelmed global fallout ${ }^{231}$ I within the $40-\mathrm{km}$ radius.

Slope analysis is only a cemi-quantitative tochnique. Although alopes near -1 and 0 can be attributed almoen exclusively to SRS and global fallout, respectively, the relative contributions of both sources to intermediate slopes cannot be quantified because of the variable conditions in the eavironment. However, an intermediate slope of -0.2 or steeper (more negative) is adopted as the criterion for SRS being the principal source of ${ }^{131}$ I in the local offaite enviroament. This is based on Figure 4-4, which illustrateo hypothetical concentrations due to global fallout and SRS relesses.

In Figure 4-4 the SRS component has the ideal slope of -1.0 and comprises 50 percent of the total concentration at the $11-\mathrm{km}$ radius from the center of the separations facilities; the site perimeter ranges from approximately 11 to $20 \mathrm{~km}$ mesesurod from the center of the chemical sepantions facilities. The slope of the total concentration curve between the $11-\mathrm{km}$ radius and the $40-\mathrm{km}$ radius is -0.37 . The slope would be steeper if the SRS contribution were greater than 50 percent at $11 \mathrm{~km}$.

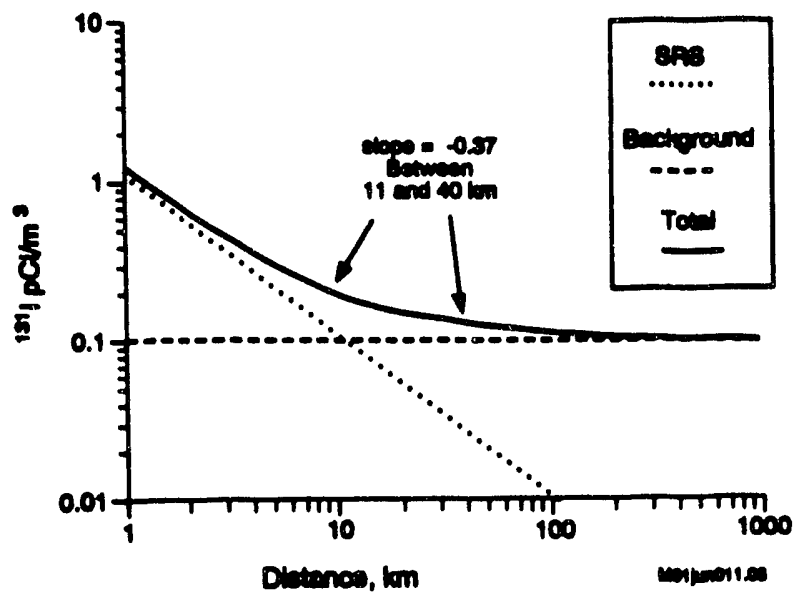

Degure 44 Example of SRS and Global Fallout Composents of Hypothetical ${ }^{131}$ I Concentrations beyond $1 \mathrm{~km}$ from the Separations Facilities

The criterion for SRS being the principal source is besed on the slope when SRS contributes 50 percent at the neareat offsite location $(11 \mathrm{~km})$. This slope of -0.37 is conservatively reduced by a factor of two in order to sccount for less then ideal conditions and for the scatter in the ${ }^{131} \mathrm{I}$ measurement reaults (see Figure 4-3). Thus, for this report a slope of -0.2 or steeper distinguishes SRS from global fallout as the principal source of ${ }^{131}$ I in the local environment.

Table 4-1 shows the slopes of the regrescion line for the years that 131 was detectod. SRS releases were the principal cource in 1955-1959 and 1961-olopes ranged from -0.3 to -1.1. Similar negative slopes $(-0.5$ to -1.2$)$ were 
observed for atmospberic tritium concentrations in the vicinity of SRS (Murphy at al., 1990).

Table 4-1. Slopes of annual average ${ }^{131}$ I concentrations in air as a function of distance

\begin{tabular}{l|l}
\hline Year & Slope \\
\hline 1955 & -0.46 \\
1956 & -1.05 \\
1957 & -0.52 \\
1958 & -0.27 \\
1959 & -0.62 \\
1960 & -0.11 \\
1961 & -0.32 \\
1962 & -0.06 \\
1963 & 0.00 \\
\hline
\end{tabular}

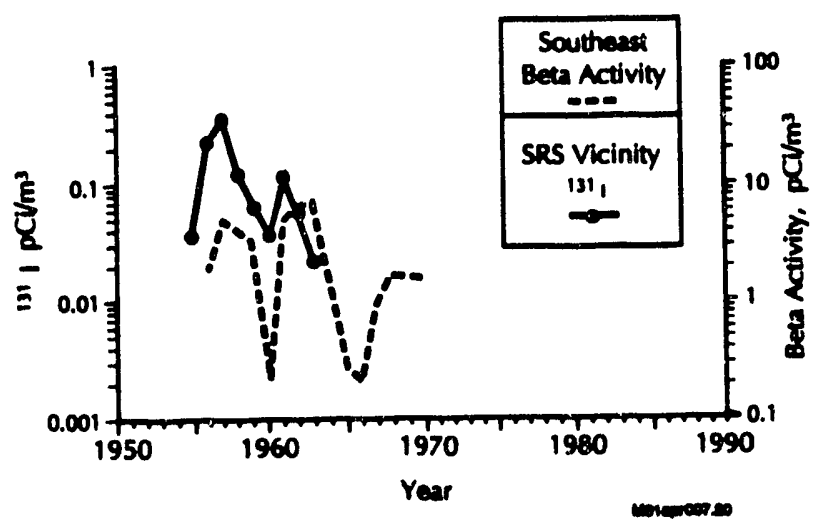

Flgure 4-5. Annual Average Concentrations of ${ }^{131} I$ in Air at the 20-km Radius from 1955 through 1989 Compared to Annual Average Concentrations of Particulate Beta Radioactivity in Southeastern Air from 1956 through 1970

The regression line is used to determine the annusal average concentration of ${ }^{131} I$ in air at the $20-\mathrm{km}$ radius for comparison with the PHS network results. The $20-\mathrm{km}$ redius from the center of the chemical separations areas represents all offsite concentrations that are close to the site perimeter. Annual average concentrations of ${ }^{131}$ I are shown in Figure 4-5 for the years that ${ }^{131}$ I was detected. The ${ }^{131}$ I concentrations are compared to annual average concentrations of particulate beta radioactivity in southeastem air. Because the PHS networks did not measure ${ }^{131} \mathrm{l}$, only the patterns in the PHS and SRS dats can be compared.
In the absence of ${ }^{131}$ I messurements in the PHS networks, the concentrations of beta setivity in the particulate fraction of southeastern air serve as an indicator for the presence of elevated global fallout ${ }^{131}$ I. This is because the arrival of fresh fallout from an atmospheric teat causes beta sctivity in air to increase; fresh fallout contains short-lived beta-emitting radionuclides including ${ }^{131} \mathrm{I}$.

Although PHS network measurements continued beyond 1970, only the data through 1970 are used for this comparison. The data were taken from the references: PHS, 1960; PHS, 1962a; PHS, 1963a; PHS, 1964a; PHS, 1965a; PHS, 1966a; PHS, 1967a; PHS, 1970a; PHS, 1971; and EPA, 19712.

The ${ }^{131}$ I concentrations prior to 1960 were greater than expected by the bet activity concentration pattern. Qualitatively, the excess is attributed to SRS releases, which for thoee years was the principal source of ${ }^{131}$ I 2000 rding to the slope analysis. The alope analyais aleo shows that global fallout was the principal source of ${ }^{131}$ I in 1960, 1962, and 1963. The similarity in the patterns of ${ }^{131}$ I and beta concentrations after 1960 is consistent with that analysis.

In 1960 the ${ }^{131}$ I concentration did not undergo the order-ofmagnitude decrease observed for beta activity. This is partially due to the numerous monthly average concentrations that were below detection limits during July to December; these are not included in the annual averagoonly the positive measurements are averaged. This results in an average annual concentration that is conservatively greater than the actuul annual concentration.

In 1963 the more rapid docrease in ${ }^{131}$ I concentration than in beta activity may have been due to the short half-life of ${ }^{131} \mathrm{I}$. Longer-lived beta sctivity persisted in the atmosphere well into 1963 following the intense testing in 1962 (Figure 4-1). Consequently, the annual beta activity concentration in 1963 is the greatest in the history of the southeastern PHS network stations despite the cessation of atmospheric tests in December 1962.

The lack of detectable ${ }^{131}$ I after 1963 is consistent with the general absence of fresh fallout as evidenced by the decrease in beta sctivity concentrations. Although beta ectivity concentrations increased from 1967-1970, they did not approach the level that was attained in 1962-1963. Consequently, annual average ${ }^{131}$ I concentrations in 1967-1970 remained below detection limits in the absence of SRS releases similar to those of the late 1950s. 
Another sourcs of radioiodine releasen to the atmosphere is volatilization from the seepage basina A limited andy of ${ }^{13 I}$ I volntilization from the seepage basins in the separations arens was conducted in the early years of aite operations when squeous rolenses were the grentent. The average atmoapheric ${ }^{\text {InI }}$ concentration approximately 8 meters downwind from F Seepage Baxin 1 was $2,000 \mathrm{pCi} / \mathrm{m}^{3}$ in 1956; it was $5,000 \mathrm{pCi} / \mathrm{m}^{3}$ approximutely eight meter downwind from H Saepage Baxin 1. Dilution and deposition during atmoepheric transport would have reduced the concentrations to approximately $0.01 \mathrm{pCi} / \mathrm{m}^{3}$ at the $20 \mathrm{tm}$ redius. Figure $4-6$ shows that the annual average concentra. tion at $20 \mathrm{~km}$ in 1956 was greater then $0.1 \mathrm{pCi} / \mathrm{m}^{3}$. Stack releases of ${ }^{211}$ from the separations areas overwhelmed the ${ }^{23 I}$ I volatilized from the seepage basins.

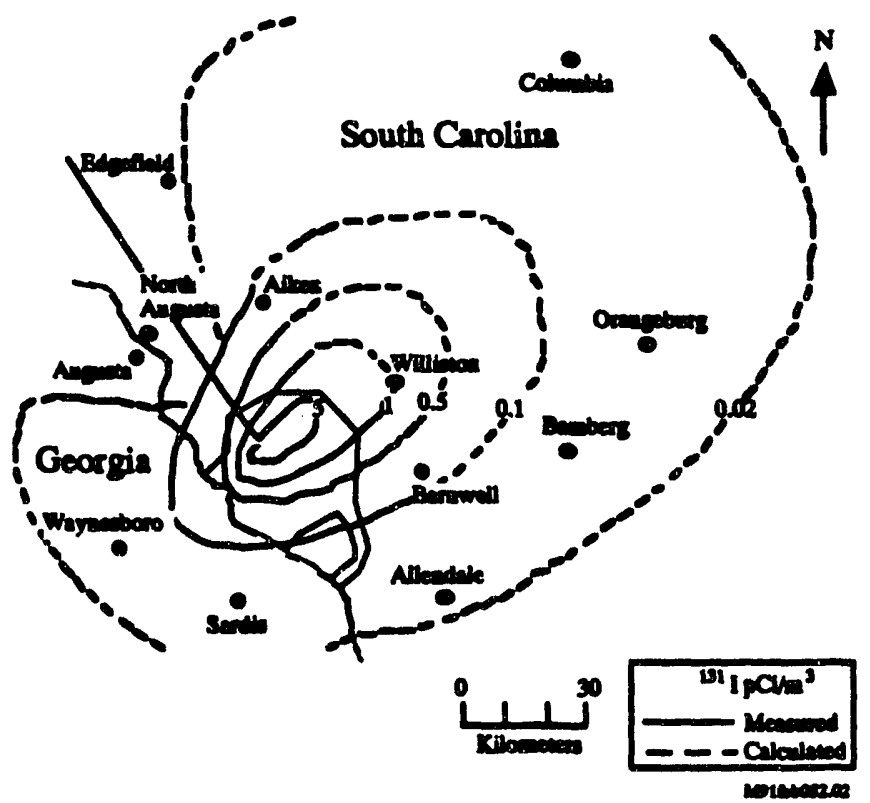

Figure 4-6. Measured and Calculated Concentrations of ${ }^{131}$ I in Air ( $\left.\mathrm{PCi} / \mathrm{m}^{3}\right)$ Near SRS for May 30 through June 7 During the 1961 Release Incident at SRS

The only scute ${ }^{131}$ I release incident due to the inadvertent reprocessing of very short-cooled materials occurred during May and June 1961. The magaitude of this release clearly influenced the offrite ${ }^{131}$ I concentrations as shown by the contours of messured and calculated concentrations in Figure $4-6$ (Marter, 1963). Because calculated concentration agreed favorably with measured concentrations, the calculated results were assumed to represent the sctual concentrations at distances beyond the locations anmpled. The maximum offisite concentrations of ${ }^{23} I$ were in the range of 1 to $5 \mathrm{pCi} / \mathrm{m}^{3}$, which did not exceed the 1961 SRS guideline of $100 \mathrm{pCi} / \mathrm{m}^{3}$ for the population at large (Marter, 1963).
Similur elevated concentrations of ${ }^{131}$ I in local air were obeerved following a Chinese atmoepheric nuclear weapons teat on December 28, 1966. The maximum concentration in individual local offaite air amples was $2.6 \mathrm{pCi} / \mathrm{m}^{3}$ when the fullout arrived in early 1967.

Elevated ${ }^{131}$ I concentrations in local air were also obeerved following the Chernobyl sccident in 1986. The maximum 11I concentration detected was $1.1 \mathrm{pCi} / \mathrm{m}^{3}$. Volutile forms comprised an average of 60 percent of the total particulate and volntile ${ }^{131}$ I mensured. The maximum particulate concentration of $0.4 \mathrm{pCi} / \mathrm{m}^{3}$ is consintent with the maximum obeerved in the couthenst in the EPA network. The maximum of $0.6 \mathrm{pCi} / \mathrm{m}^{3}$ cocurred in Jacksonville, FL (EPA, 1986a). (In response to the Chernobyl sccident, EPA anlyzed particulate air amples and precipitation anples by gamma spectrometry in addition to the beta ectivity measurement.)

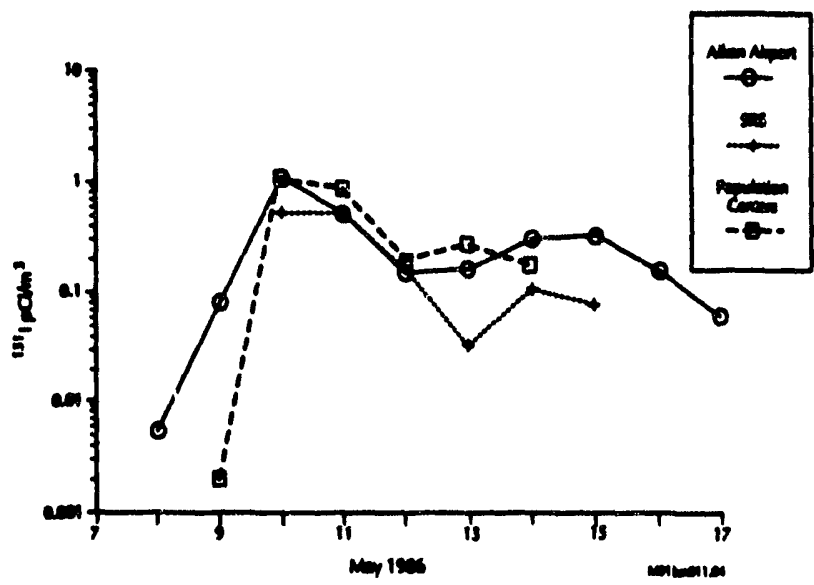

Desure 47. Measured Air Concentrations of ${ }^{131} 1$ Near SRS Following the 1986 Chernobyl Resc. tor Accident

Measured local concentrations at SRS, the Aiken Airport, and several nearby population centers are shown in Figure 4-7. The TRACmobile laboratory (Appendix B) monitored air at celected population centers within the $160-\mathrm{km}$ radius of SRS (Sigg, 1986; Sige, 1989). The TRAC was at the following locations on the following dates in 1986:

- May 9-Madison, OA

- May 10 between Barnwell, SC, and Interatate-95

- May 11-Savannih, GA

- May 12-Augute, GA

- May 13-Columbia, SC

- May 14-Greenville, SC 
At SRS and Aiken Aipport, air was continuously sampled with fixed air sampler. The Administration area (next to SRL in Figure 3-1, page 17) was sampled a SRS. The Aiken Airport is approximately $40 \mathrm{~km}$ north of the geographic center of SRS.

After peaking on May 10, total ${ }^{131}$ I concentrations slowly decreased with occasional increases such as the one on May 13-14. No ${ }^{131}$ I was detectable at the Aiken Airport after June 25 (Kantelo and Winn, 1986). Longer-lived radionuclides in the Chernobyl debris were detectable at Aiken Airport until the end of Auguat 1986 (Winn and Kantelo, 1989).

Measurement uncertainties (one standard deviation) in the total ${ }^{131}$ I concentrations were typically less than 10 percent. Results for May 11 and 12 at the three sampling locations are in good agreement. The spread in the concentrations for the other days reflects several factors. During repidly changing concentrations such as on May 9, the concentration determined from the short sampling interval on board TRAC is expected to differ from the average concentration for a 24-hour sampling interval at the Aiken Airport. Also, concentrations at geographically separate locations are expected to differ. Such geographic differences, which are due in part to inhomogeneous mixing of the debris in the atmosphere, were observed in global fallout during the 1950 s and 1960 s (Bruner, 1963).

Measurements of ${ }^{120}$ in air are spase. Atmospheric concentrations of ${ }^{121}$ near SRS were only determined in 1975. High sensitivity neutron activation analysis was used to determine the low environmental levels of ${ }^{129} 1$. Concentrations of approximately $6 \times 10^{5} \mathrm{pCi} / \mathrm{m}^{3}$ were detected from the site perimeter to the 160-km radius (Hochel, 1976). (Background ${ }^{129}$ I air concentrations in North America are on the order of $10^{\circ} \mathrm{pCi} / \mathrm{m}^{3}$ [Brauer, 1974].) The absence of a decrease with distance from SRS may have been due to a bias in performing ${ }^{129} \mathrm{I}$ analyses at very low concentrations (Hochel, 1976).

\section{Deposition in Rain}

Entrainment in rainwater is one of the mechanisms for removal of radioiodine from air. Rainwater was one of the first types of environmental samples specifically analyzed by SRS for ${ }^{131}$ I. These analyses began in mid 1954. Rainwater is collected at locations onsite, near the site perimeter, and near the $40-\mathrm{km}$ radius from the geographic center of the site. Four rainwater stations near the $160 \mathrm{~km}$ radius were added in 1978 . Two of the distant stationsColumbia and Greenville, SC-are located in cities that are part of the nationwide rain sampling networks.
Measurement results from each sampling station have been published in two different formats in the SRS environmental reports. The initial results were reported as annual average concentrations (activity per unit volume). The results after 1961 have been reported as annual average deposition (activity per unit surface area); these are determined by multiplying a measured concentration by the corresponding volume of water collected and dividing by the area of the collecting surface.

For this report all the rainwater results are expressed in units of deposition $\left(\mathrm{pCi} / \mathrm{m}^{2}\right)$. The initial data that were reported as annual average concentrations in the environmental reports have been converted to deposition using the average SRS rainfall for each corresponding year.

Locations close to the separations areas have shown detectable ${ }^{131}$ I in most years. Near the perimeter and $40-\mathrm{km}$ radius, ${ }^{131}$ I was detected from 1955 through 1963. After 1963 it was detected at the offsite locations only occasionally.

Table 4-2 shows the results of slope analysis of the rainwater data. SRS was the principal source of ${ }^{131}$ I in local rainwater in 1955-1957, 1959, 1961, 1976, and 1977. Slopes ranged from -0.3 to -0.9 . This is consistent with the slope of -0.8 observed for tritium in rain near SRS (Murphy et al., 1990).

Table 4-2. Slopes of annual average ${ }^{131}$ I concentrations in rainwater as a function of distance

\begin{tabular}{l|c}
\hline Year & Slope \\
\hline 1955 & -0.88 \\
1956 & -0.65 \\
1957 & -0.26 \\
1958 & 0.01 \\
1959 & -0.35 \\
1960 & -0.09 \\
1961 & -0.60 \\
1962 & -0.02 \\
1963 & 0.01 \\
1966 & 0.14 \\
1967 & -0.17 \\
1970 & -0.05 \\
1976 & -0.57 \\
1977 & -0.31 \\
\hline
\end{tabular}

Table 4-2 does not include 1972, 1978, and 1986 when deposition was below $1,000 \mathrm{pCi} / \mathrm{m}^{2}$. Values below 1,000 
pCi/m $m^{2}$ are near the detection limits and the alope andysis is not sccurate with wech statiatically poor date.

Annual average deposition values for ${ }^{131} I$ in rninwater at the $20 \mathrm{~km}$ radius from the separations areas sre shown in Figure 48. Theee are compared to the annual average deposition velues for beta radiosctivity in southenstern ninwater and the annual average concentrations of particulate bete radiosctivity in southenstern air.

Athough PHS min measurements have continued each year, the only networt data used beyond 1970 corresponds to the years that ${ }^{13}$ I was detected in the local environment. Beta ectivity deposition values are taken from the references: PHS, 1960b; PHS, 1961; PHS, 1962b; PHS, 1963b; PHS, 1964b; PHS, 1965b; PHS, 1966b; PHS, 1967b; PHS, 1968; PHS, 1969; PHS, 1970; PHS, 1970b; EPA, 19712; EPA, 1972a; BPA, 1973a; EPA, 1976; EPA, 1977a; EPA, 1978a; and EPA, $1986 \mathrm{~b}$.

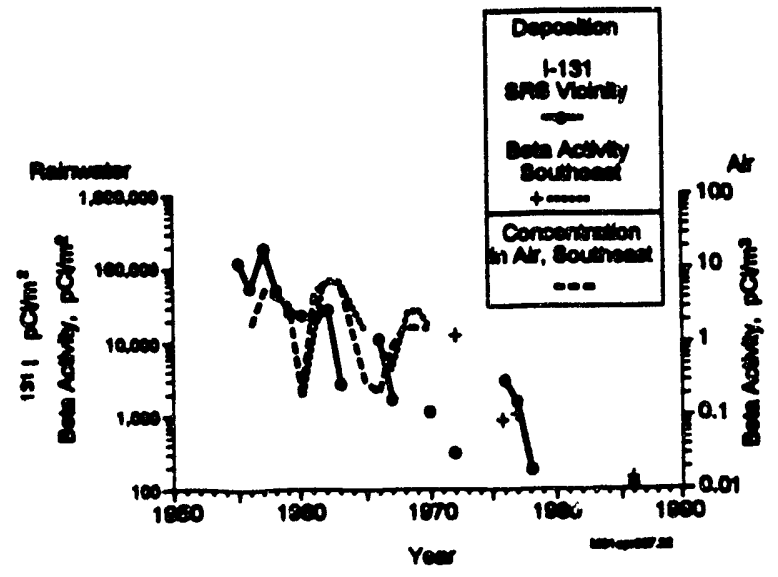

Nigure 48. Annual Average Deposition of ${ }^{131}$ I in Rain at the 20-km Radius from 1955 through 1989 Compared to Annual Average Deposition of Beta Radiosctivity in Southeastem Rain (1960 through 1970 and Intermittently to 1986) and Annual Average Concentrations of Particulate Beta Radiosctivity in Southeastern Air (1956 through 1970)

In the absence of ${ }^{11}$ I measurements in the PHS min network, the deposition of bets sctivity in southenstern rain serves as an indicator for the presence of rain that contrins fallout ${ }^{131}$ I. Because the patterns of beta sctivities in min and air agree, the pattern of air concentrations is considered to represent the pattern of rain deposition for the years prior to the beginning of network rain andyses in 1960 .
Figure 48 shows only margind agreement in the pattern of local ${ }^{131}$ I deposition and southentern beta sctivity deposition from 1956 through 1970 . One reason for the diangreement is thr ruinfall is often a local condition; comparison to the average min in the southesstern region is not always valid.

The increases in local and southeastern deposition after 1970 are principally due to fallout from Chinese nuclear weapons teats.

Fallout ${ }^{131}$ I from the Chernobyl sccident was detected in 1986. The local maximum ${ }^{231}$ I concertution wes $100 \mathrm{pCi} / \mathrm{L}$ (not converted to deposition). This occurred on May 14 and was not coincident with the maximum ${ }^{231} 1$ air concentrations of May 10 and 11; rain did not fall on those days. The local meximum concentration is consistent with the meximum concentration in the EPA network in the southent. This is $110 \mathrm{pCi} / \mathrm{L}$ in Nashville, TN (BPA, 1986a).

The 1954 measurements of ${ }^{131} I$ in minwater are not included in the previous discuscion of annual depocition becuss the andyee begn in mid 1954. Concentrations of ${ }^{121}$ in minwater during July-December 1954 muged from 2050 pCi/L. The concentrations show no consintent change with distance. Therefore, the ${ }^{19} I$ is attributed to global follout.

\section{Terrestrial Deposition}

Radioiodine is deposited from the air onto the terreatrial environment by wet and dry depacition. Short-lived ${ }^{131}$ I has not been detected in gamme spectrometric analyais of periodic soil samples. Preliminary studies of ${ }^{120} 1$ concentratiom in surface soil near SRS were conducted in 1971 and 1975. Concentrations in the 1971 study were $6 \times 10^{4}$, $5 \times 10^{4}$, and $2 \times 10^{5} \mathrm{pCi} / \mathrm{g}$ at Jackevn, SC (13 km from the center of the separations areas), Augusth, GA (28 $\mathrm{km})$, and Madicon, GA (100 km), respectively (Braver, 1974). (The North American background of ${ }^{2 m}$ in soil is on the order of $10^{6} \mathrm{pCi} / \mathrm{g}$ [Brauer, 1974].) The slope of the concentration change with distance is approximasely -2.

In the 1975 study, the slope is approximately -1.3 for 127 concentrations of $0.021,0.005$, and $0.0010 \mathrm{pCi} / \mathrm{s}$ at the site perimeter and the 40 and $160 \mathrm{~km}$ radii, respectively (Hochel, 1976). These concentrations are one to two orders of magnitude greater than the 1971 results at correxponding distances. SRS did aot release sufficient 1201 between 1971 and 1975 to sccount for such large discrepancies in surfece concentrations. They are attributed to differences in the number and depth of surface anmples at each location, the 
length of time the soil had been undisturbed, forested compared to unforested sampling locations, and the soil retention characteritios for iodine.

The preliminary studies led to a comprehensive study of the cumulative ${ }^{220}$ deposition in the terrestrial environment surrounding SRS. During 1978-1979 vegetation and litter from the surfice and soil from $60-\mathrm{cm}$ deep cores were collected at distances of approximately 20,40,80, and 170 kilometers from the center of the chemical separations fecilities alons rediv lines in five compess directirns (Anderson, 1978; Kantelo et al., 1982).

Mout ampling bactions were in foreated areas. All locations had been undisturbed for at leas 25 yeara. Multiple cores and vegetation/litter anmples were collected at esch location. A composite sumple of the vegetation/litter whe prepared for each location. Each core was sectioned into $2.5-\mathrm{cm}$ segments at depths of $0,15,30$, and $60 \mathrm{~cm}$ and a composite sample for each specified depth was prepared for each location. The composite samples were analyzed for ${ }^{12} 1$ using neutron sctivation analysis.

Concentrations of $12 \%$ in the $2.5-\mathrm{cm}$ surface layer are intermediate between the values in the two preliminary studies at corresponding distances. However, the purpose of the comprehensive study was to determine the cumulative deposition rather than aurface concentrations alone.

Cumulative deposition was determined by integrating the vertical soil deposition profile and adding the deposition in the vegetation/litter layer, which typically comprised lese then 10 percent of the total. This small degree of iodine retention in the vegetation/litter might have been caused by biological degradation, which did not allow the fallen litter layer to retain iodine for many years. The cumulative deposition of ${ }^{120}\left(\mathrm{pCi} / \mathrm{m}^{2}\right)$ at each of the four sampling locations along each radial sampling line is sbown in Figure 49.

The slope of the regression line through the data for all compass directions is -1.5, which demonstrates that SRS was the source of the ${ }^{12} \%$. A slope of -1.5 means that deposition decreases by a fector of 2.8 for every doubling of distance. The slope is slightly steeper than the -12 slope observed for tritium in soil in the vicinity of SRS (Murphy et al., 1990).

Two data points were not used to fit the regression line. These are at distances of 19 and $80 \mathrm{~km}$ in the couth-southeas (SSE) direction and represent the only ampling locations in open fields. Figure 4-9 shows tiat deposition in the forested locations was three to four times greater than the deposition in open fields. Although this conclusion is based on very limited dath, it is consistent with simiiar cibervations of $12 \%$

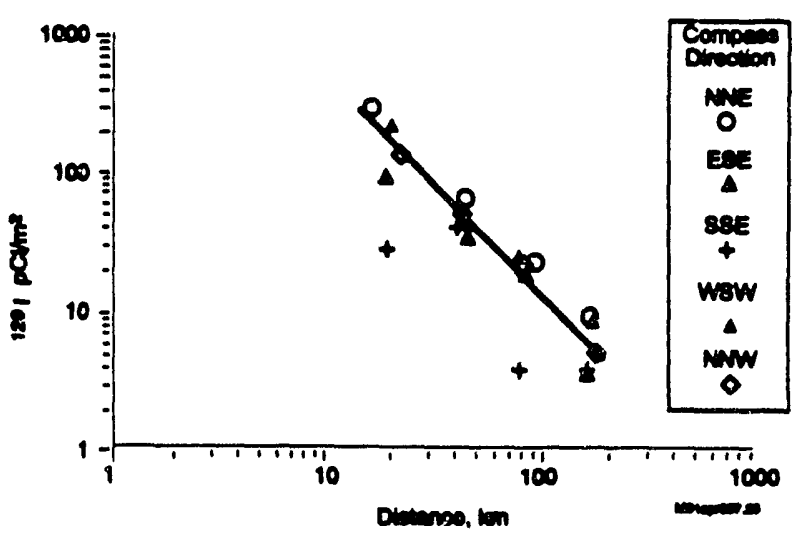

Dezare 4-9. Variation in the Cumulative Terreatrial Deposition of ${ }^{22} 1$ with Distance from the Center of the Chemical Separations Facilities , as of 1978-1979

deposition near a former nuclear fuel reprocessing plant in Weat Valley, New York (Brauer and Strebin, 1982). Similar behavior is observed for zinc, lead, and cadmium near a amelting plant (Little and Martin, 1972).

Deposition in forested areas is grenter then in unforested areas because the foreat scts as a filter for iodine. The turbulence created as air paseen through lenves, pine needles, branchea, and vegetation provides greater opportunity for removal of iodine by physical and chemical mechanisms in forests than in open areas. Iodine-contrining leaves, pine needles, bark, and vegetation eventually become part of the litter layer from which iodine is leached into the soil.

Contours of the terreatrial deposition of ${ }^{12} I$ in the vicinity of SRS were obtained by combining the results for forested locations shown in Figure $4 \mathbf{9}$ with SRS wind rose data for 1976-1978. The contours shown in Figure 4-10 converge on SRS and clearly demonstrate the concept that strongly negative slopes in all compase directions indicate atmospheric transport from a relesse point. At a distance of $\mathbf{2 0 0}$ $\mathrm{km}$, the extrapolated deposition is atill an order of magnitude greater then the expected background, which is on the order of $0.1 \mathrm{pCi} / \mathrm{m}^{2}$ in North America (calculated from Ricknrd et al., 1974, ascuming a 7-cm half-depth).

By the time of this terrestrial distribution atudy, SRS had relensed a cumulative total of 4.7 curies of ${ }^{12} 1$ to the atmoephere. Based on the results in Figure 4-10, spproximately 45 percent (2.1 curies) was preseat in the terrectrial area ranging in radial distance from 7 to $200 \mathrm{~km}$ (Kentelo et a., 1982). The 2.1 curie inventory is an overestimate because it is based entirely on the forested data; open areas 


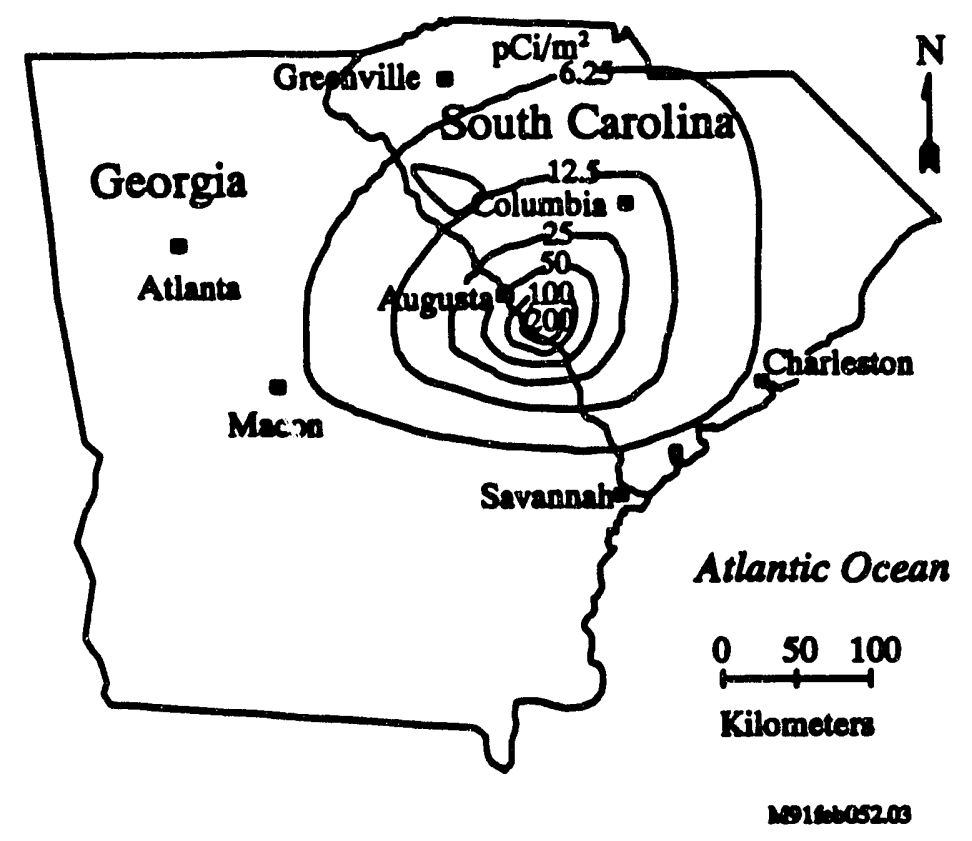

Fogure 4-10. Contours of the Cumulative Terrestrial Deposition of ${ }^{121}\left(\mathrm{pCV} / \mathrm{m}^{2}\right)$ Surrounding SRS, as of 1978-1979

Table 43. Half-depths for downward transport of deposited ${ }^{12}$ I through coutheastern soil

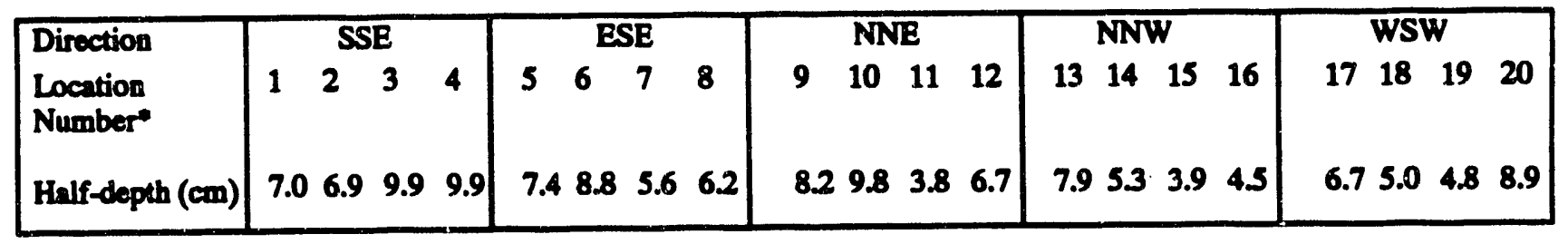

- Sampling locations are numbered along each compass direction by increasing distance from center of reprocesaing areas. Typical distances are 20, 43, 84, and $166 \mathrm{~km}$.

were not taken into scocount. Thus, the sctual inventory is less than calculated.

Despite the limitations of the inventory method, the 2.1-curie inventory compares favorably with a predicted inventory of 2.4 to 3.8 curies based on deposition from the 4.7-curie cumulative release. Calculations predict that 50 to 80 percent (depending on deposition velocity) of the 217 should be deposited in the 7- to 200-km range (Murphy, 19918; Murphy, 1991b). The calculations do not consider jodine removal procesees such as volatilization or ninwater runoff. These result in an sctual inventory smaller than predicted. This comparison demonstrates that the calculational method for ${ }^{121}$ atmospheric releases (Chapter 3) likely did not undereatimate the actual releasea.

The vertical soil profile at each location shows an exponential doctease in deposition with depth. Yelf-depthe (analo- gous to half-life in radiasctive decay) range from 4 to $10 \mathrm{~cm}$ with a mean of $7 \mathrm{~cm}$, as shown in Table 4-3. The variations in half-depth do not correlate with any measured soil charecteristices, which consisted of $\mathrm{pH}$, cation exchange capacity, and the content of clay, sand, silt, and organic matter.

The amall values of half-depth demonstrate that airborne ${ }^{229}$ deposited in the terreatrial environment is efficiently retrined nent the soil surface. The half-deptb values were included in a database to develop a mathematical model for the movement of deposited i2I in southenstern soils. Modelling reeults predict a 30 -year mean effective residence time in the top $30 \mathrm{~cm}$ (Boone et al., 1985).

Deposited 291 has also boen obeerved to be efficiently retrined near the surfece in the vicinity of other nuclear fuel reproceaning facilities that experience different climatic and 
soil condition The facilities studied were Nuclear Fueir Services in Now York (Rickand at al, 1974; Brawer and Strebin, 1982), Hanford in Washington (Rickard of al., 1974; Braver and Strobin, 1982), the Karlarube Reprocessing Plant in Germany (Schuttelkopf and Pimpl, 1982; Robens et. al, 1989), the Sellafield Works in England (Stowart and Wilkins, 1985), and the Power Reactor and Nuclear Fuel Development Corporation in Japan (Muramatsu and Ohmomo, 1986).

\section{Vegetation}

Radioiodine principally accumulates in vegetation by wet and dry deposition. The accumulation is generally proportional to the exposed surface area of vegetation. Large or dense foliage is expected to sccumulate the greatest concentrations of aitorne radioiodine. Accumulation depends on the growing saason. Uptake through the root system is leas significant for ${ }^{131}$ I than ${ }^{201}$ d due to half-life considerations.

SRS began periodic sampling of vegetation for ${ }^{13}{ }^{13}$ at various locations between the center of the site and the perimeter, near the perimeter, and near the $40-\mathrm{km}$ radius in 1955. Sampling near the $160-\mathrm{km}$ radius was added in 1974. Although the type of vegetation collected is not always specified in the environmental reports, Bermuda grass is collected when available. This is the principal forage crop for dairy cattle in the SRS vicinity.

In most years 231 I was detected at locations close to the separations areas. Near the perimeter and 40-km radius, ${ }^{131}$ I was detected in the eight years from 1955 through 1962. After 1962 it has been sporadically detected at offsite locations.

The slope analysis technique cannot be rigorously applied to the results because annual average concentrations of ${ }^{131} I$ in vegetation are reported for general radial distances from the geographic center of the site rather than for each specific sampling location. However, the general radial distances provide an approximation for the slope analysis.

Table 4-4 shows the results of such slope analysis. SRS was the principal source of ${ }^{131} I$ in local vegetation during 1956 , 1959,1961 , and 1967. Estimated slopes range from -0.2 to -0.7 . A slope of -1.0 was obeerved for tritium in vegetation near SRS (Murphy et al., 1990). Slopes for 1959, 1960, 1962 , and 1967 were determioed only from the JanuaryJune results; July-December results in those years were below detection limits. Slopes for 1958 and 1970 could not be determined by this technique. In 1958 no 40-km samples
Table 4h. Approximate slopes of annual average ${ }^{231} I$ concentrations in vegetation as a function of distence

\begin{tabular}{l|r}
\hline Year & Slope \\
\hline 1955 & 0.1 \\
1956 & -0.7 \\
1957 & 0.0 \\
1959 & -0.2 \\
1960 & -0.1 \\
1961 & -0.3 \\
1962 & 0.0 \\
1967 & -0.2 \\
\hline
\end{tabular}

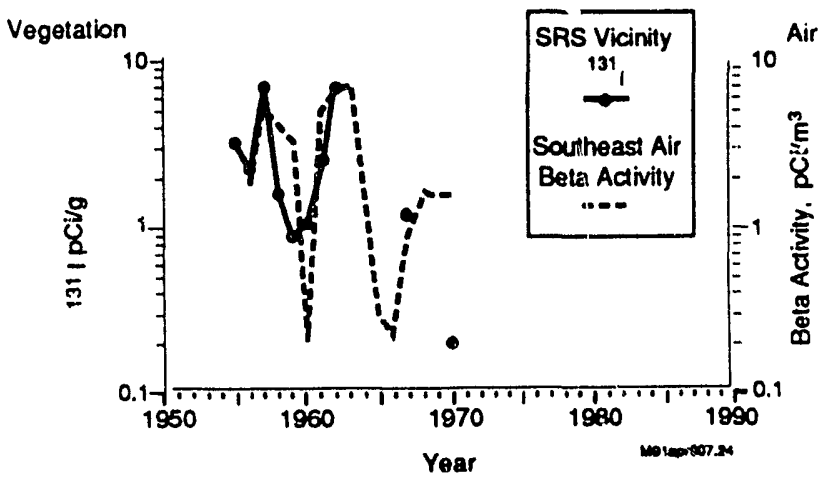

Figure 411. Annual Average Concentrations of ${ }^{131} \mathrm{I}$ in Vegetation at the 20-km Radius from 1955 through 1989 Compared to Concentrations of Particulate Beta Radionctivity in Southcastern Air from 1956 threugh 1970

were collected. In $1970{ }^{131}$ I was detected only near the 40-km radius.

The annual average concentrations of ${ }^{131} I$ in vegetation at the $20-\mathrm{km}$ radius from the center of the separation areas are shown in Figure 4-11. The year-to-year variations in the data are compared to particulate beta radioactivity in southeastern air, radioactivity in vegetation was not measured by the nationwide networks.

The pattern of local ${ }^{131}$ I vegetation concentrations closely follows the pattern of beta sctivity concentrations in southenstern air. The 1960 plotted local concentration is conservatively high in that it represents only the JanuaryJune semi-annual average; the July-December value was below the detection limit. 


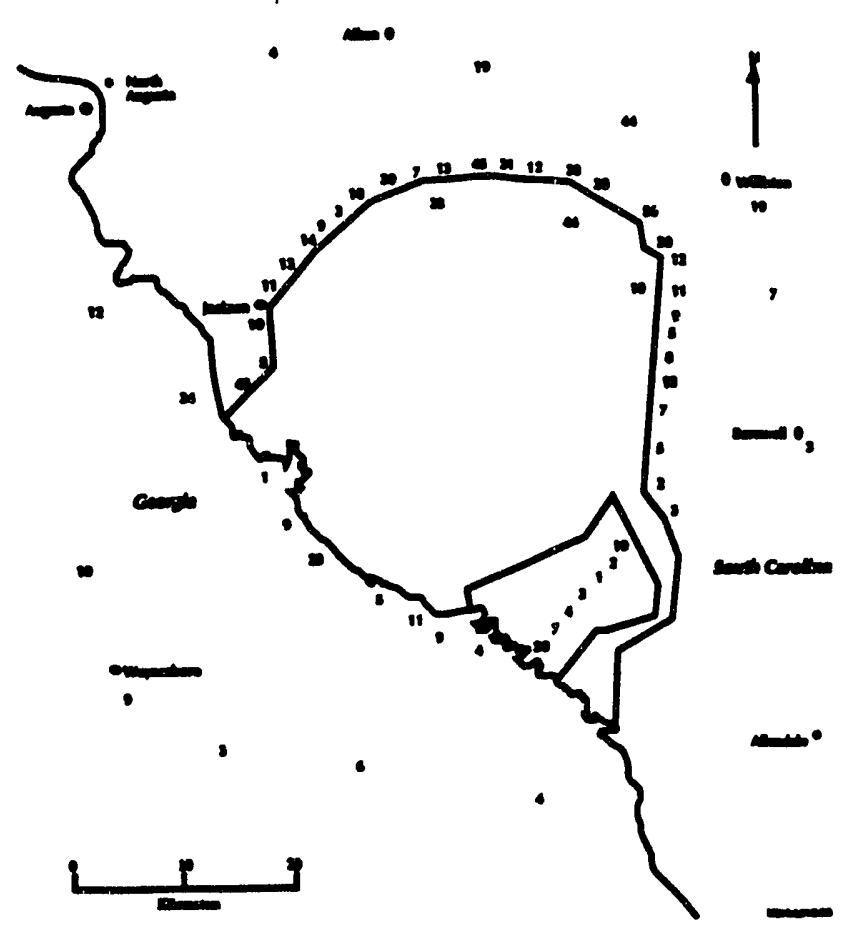

Fegure 4-12. Mensured Concentrations of ${ }^{131} \mathrm{I}$ in Bermuda Gras (PCi/g) Near SRS on June 5 Following the 1961 Release Incident

Following the 1961 scute release of ${ }^{12 I}$ from F-Area separations facilities in late May and early June, Bermuda grass was collected onsite and offsite. Results for the sumples collected on June 5, are shown in Figure 4-12 (Marter, 1963).

The pattern of ${ }^{131}$ I concentrations in vegetation is consistent with the pattern of air concentrations for the incident. The activity of ${ }^{131}$ I on Bermuda grass decreased with an apparent half-life of 5 days compared to its radiological half-life of 8 days. The difference is attributed to dilution by new vegetative growth (Marter, 1963). The maximum offaite concentration was $56 \mathrm{pCi} / \mathrm{g}$ near the northeast perimeter of the site. For comparison the maximum offsite local ${ }^{131}$ I concentration due to intermittent global fallout after 1963 is $9 \mathrm{pCi} / \mathrm{g}$ this occurred in 1976 and 1977.

The maximum concentration of ${ }^{131}$ I within the SRS boundary at the beight of the 1961 release incident was $1,110 \mathrm{pCi} / \mathrm{g}$. Even greater concentrations were observed later in June near the F-Area ceepage basins after they received aqueous wastes from the incident. The maximum concentration of ${ }^{131} I$ in vegetation was $485,000 \mathrm{pCi} / \mathrm{g}$ due to volatilization of ${ }^{131}$ from the adjecent seepage basins. The mochrairm of volatilization from the seepage basins in the separations areas had been demonstrated in 1956; fifty meten from $H$ Seepage Basin 1 the annual average concentration of ${ }^{131} \mathrm{I}$ in vegetation was $4,600 \mathrm{pCi} / \mathrm{g}$ and docreased with distance from the basins.

Mensurements of ${ }^{129} I$ in vegetation are sparce. Preliminary studies of ${ }^{121} 1$ in vegetation near SRS were conducted in 1971 and 1975. Concentrations in the 1971 atudy were $2 \times 10^{-4}, 3 \times 10^{s}$, and $4 \times 10^{6} \mathrm{PCi} / \mathrm{g}$ at Jackeon, SC, Augueta, GA, and Madicon, GA, respectively (Brwer, 1974). (The North American background of 121 in vegetation is on the onder of $10^{6} \mathrm{PCi} / \mathrm{g}$ [Braver, 1974].) The slope of the concentration change with dietance is approximately -2.3 , which is consistent with the slope in the corresponding study of aurfice soil.

In the 1975 study, 127 concentrations of $9 \times 10^{-3}, 4 \times 10^{-3}$, and $5 \times 10^{-3} \mathrm{PCi} / \mathrm{g}$ were observed at the site perimeter and the 40- and 160-km redii, respectively (Hochel, 1976). The slope between the perimeter and the 40-km radius is -0.9 . This is consistent with the slope in the corresponding study of surface soil. The inconsistent concentration at the $160-\mathrm{km}$ radius reflects the difficulty of analyzing for low levels of ${ }^{20 \%}$.

Concentrations in the 1975 etudy are one to two orders of magnitude greater than the 1971 results at correaponding dietances. As in the preliminary soil studies, the disagreoment between concentrations in 1971 and 1975 is attributod to sampling differences. The type of vegetation, it location in foreated or unforeated areas, and the time of year affect the 1 I concentrations.

\section{Food}

Radioiodine principally accumulates in food by wet and dry depocition. SRS began periodic analysis of local food, which consisted of food crops and animal products, in 1957. Milk and eggs are the only foods in which ${ }^{131}$ I has been detected.

Milk was recognized during the 1950 s as ansitive indicator for ${ }^{211}$ exposure through the grase-10-cow-10-human pathway. Consequently, SRS began local milk analyees in 1957. Aleo in 1957, the PHS began the Raw Milk Network, which operated through 1966. The PHS began the Pasteurized Milk Network in 1960.

SRS principally collected local milk samples at individual farms, dairies, and major millk distributors between the 20 and 40-km radius. The number of locations sampled in any given year is insufficient to perform a statiatically valid 
slope analyais. However, given the influence of SRS radioiodine relesses on other environmental media, local milk concentrations of 131 are probably influenced by SRS releases in the years that SRS is the principal source of ${ }^{131}$ in the local environment.

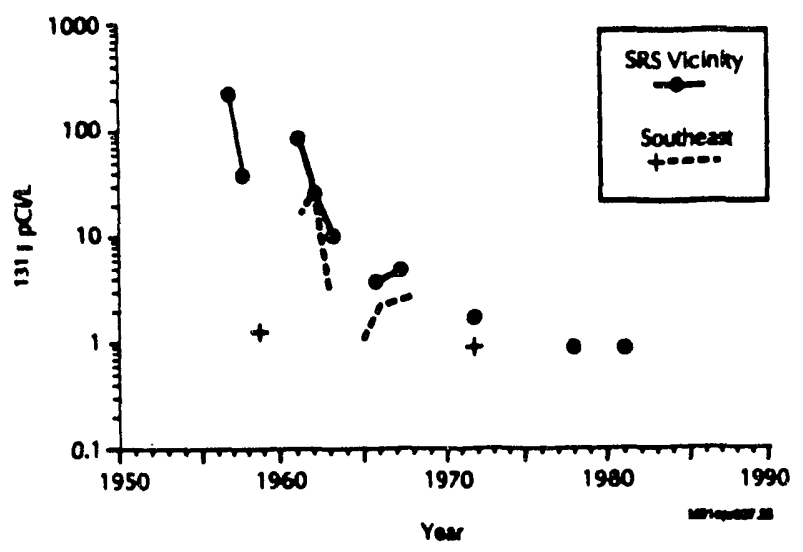

Figure 4-13. Comparison of Annual Average Concentrations of ${ }^{131} I$ in Milk Near SRS (1957-1989) and in the Southeast (1958-1970 and Intermittently to 1981)

The annual avenage concentrations of ${ }^{131} I$ in all types of local milk are shown in Figure 4-13. These are compared to the annual average concentrations of ${ }^{131} I$ in southeastern milk. The concentrations are taken from the references Campbell and Murthy, 1963; Robinson, 1968; PHS, 1962c; PHS, 1963c; PHS, 1964c; PHS, 1965c; PHS, 1966c; PHS, 1967c, PHS, 1968b; PHS, 1969b; PHS, 1970c; EPA, 1971b; EPA, 1972b; EPA, 1973b; EPA, 1978b; EPA, 1979a; and EPA, 1981.

The Raw Milk Network began in mid 1957 with five locations, none of which were in the southeast. The first annual result from a southeastern location in the network was in 1959 from Atlanta, Georgia, $230 \mathrm{~km}$ northwest of SRS. The plotted southeastern milk concentrations during 1961-1966, when the Raw Milk Network and Pasteurized Milk Network concurrently operated, are the average of the two networks. Annual average Pasteurized Milk Network concentrations are plotted from 1967 through 1970. The only network data used beyond 1970 corresponds years that ${ }^{131}$ I was detected in local mill.

In general, local and southeastem ${ }^{131}$ I concentratinns are in good agreement considering differences in sampling frequency. The local concentrations are expected to be greater than the southeastern concentrations because the SRS milk program often sampled more extensively after arrival of fresh global fallout than the networks sampled.
The sporadic appeannoce of ${ }^{131}$ in local milk after 1963 generally occurred when global fallout intermittently reappeared. The local concentrations of $0.9 \mathrm{pCi} / \mathrm{L}$ in 1978 and 1981 were close to the detoction limit, which generally was $1 \mathrm{pCi} / \mathrm{L}$. In 1978 elevated ${ }^{131}$ I was detected at only one of the five PHS southeastern stations; the annual average concentration in Montgomery, AL, was $1.4 \mathrm{pCi} / \mathrm{L}$.

The reason for the appearance of ${ }^{131} \mathrm{I}$ in local milk in 1981 is unknown. Residual ${ }^{131} 1$ from the lest atmospheric nuclear weapons test in October 1980 would not have survived into 1981. Also, SRS relesses of ${ }^{131}$ I in 1981 were not excessively large; they were consistent with releases since 1975. Results for the southeastern stations in the Pasteurized Milk Network did not exceed detection limits in 1981.

Local concentrations prior to 1959 are compared to concentrations in network citics more distant than Atlanta. The closest cities for comparison are Cincinnati, $\mathrm{OH}, 670 \mathrm{~km}$ north northwest of SRS, and St. Louis, MO, $960 \mathrm{~km}$ northwest of SRS. Because the cities are so distant, their results serve only as a guideline for the environmental levels existing in the eastern US at that time.

In Cincinnati and St. Louis, the average ${ }^{131}$ I concentrations for Auguat-December 1957 were 190 and $410 \mathrm{pCi} / \mathrm{L}$, respectively. The local average ${ }^{131}$ I concentration of 500 PCi/L for July-December 1957 is greater than, but still connistent with these values. The average concentrations in Cincinnati and St. Louia, for January-June 1958 were 5 and $17 \mathrm{PCi} / \mathrm{L}$ respectively; the local value was $14 \mathrm{pCi} / \mathrm{L}$.

The first result from Atlants was in July 1958 . The average ${ }^{131}$ I concentration for July-December 1958 in Atlanta was 26 $\mathrm{pCi} / \mathrm{L}$. The corresponding local average concentration was $60 \mathrm{pCi} / \mathrm{L}$. As in 1957, the local and regional concentrations were consistent, but the local value was greater. In general this relationship of local and soutbeastern ${ }^{131}$ I concentrations continued for the annual resulis in subsequent years.

Following the 1961 scute release of ${ }^{131}$ I from F-Area separations facilities in late May and early June, the greatest concentration of ${ }^{131} I$ in milk was $5,451 \mathrm{pCi} / \mathrm{L}$ at a farm several kilometers north of the sire perimeter. Results from the June 5-7 collections are shown in Figure 4-14 (Marter, 1963). The pattern of ${ }^{131}$ I concentrations in milk is consistent with the air pattern.

The only other perishable foods of dietary significance that were available following the release incident were egos and peaches. Fresh eggs, collocted from the farm having the greatest concentration of ${ }^{131} I$ in milk, contuined an average of $33 \mathrm{pCi}$ of ${ }^{131} \mathrm{I}$ per egg. No ${ }^{131} \mathrm{I}$ was detectod in peaches 


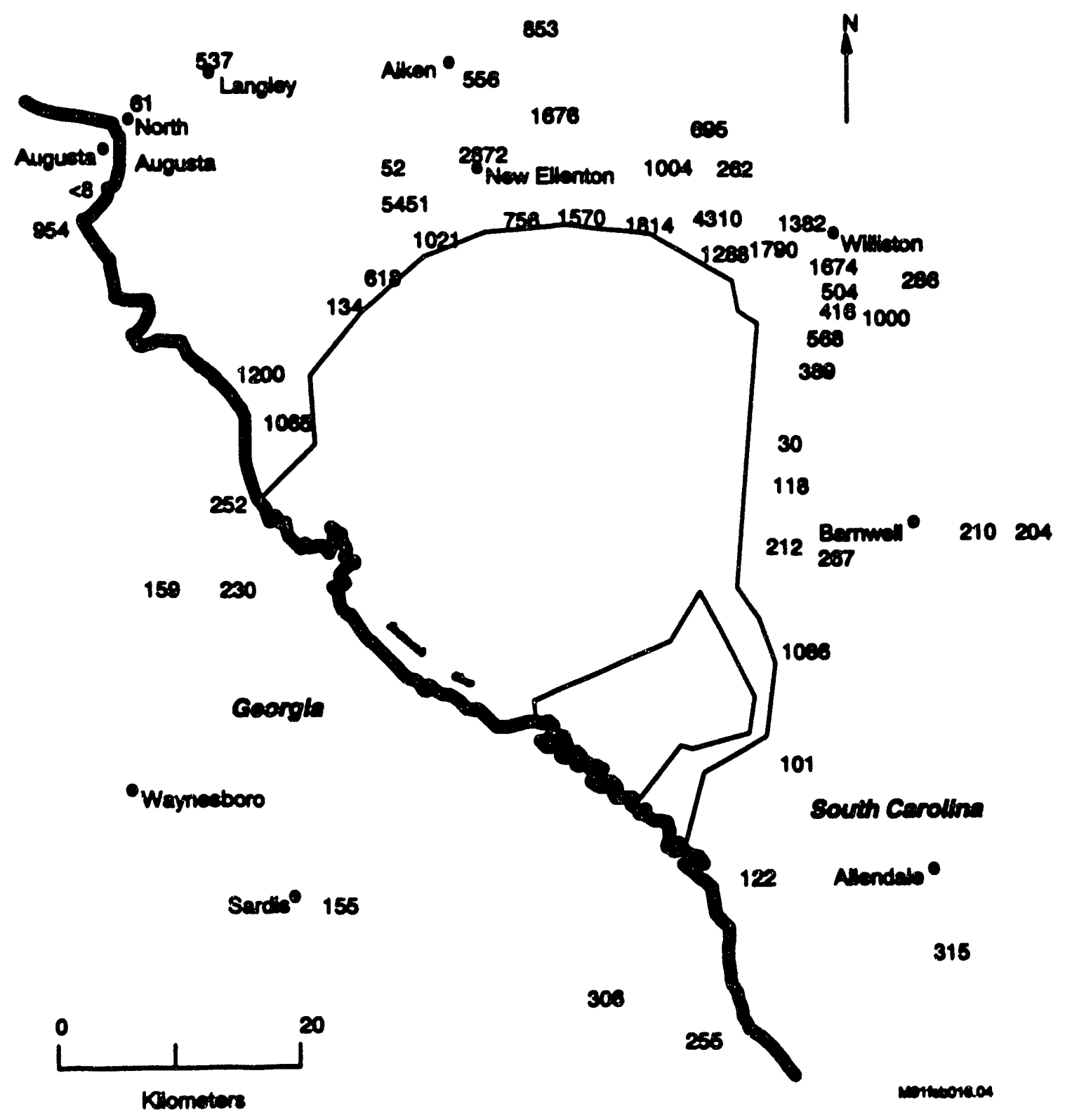

Figare 414. Measured Concentrations of ${ }^{31}$ I in Milk (pCi/L) Near SRS for June 5-7 During the 1961 Release Incident at SRS

collected from an area in the path of the release plume (Marter, 1963).

Fallout ${ }^{111}$ I from the Chernobyl accident was detocted in ose local milk ample. The ${ }^{1{ }^{11}}$ concentration was 11 pCi/L on May 29, 1986, which was almost three weeks after the arrival of the fallout. Similar concentration and delay times after arrival were observed in the Pastuerized Milk Network. Concentrations of 14-26 pCi/L were observed in
Allante, Charlotie, and Charleaton 3-4 weeks after arrival of the Chernobyl fallout (EPA, 1986).

In the carly 1960 s a significant difference was observed in 211 I concentrations in farm and deiry milk near SRS. Concentrations of ${ }^{21} I$ in farm mill were approximately a factor of 3 greater than concentrutions in dairy milk. This is atributed to the difference in feeding habite. Farm cows drink aufuce water and feed almot exclusively on pecture 
gran, both of which are expoed to freab fallout. In contrath, the diet of dairy cows includes harvected fodder and nonfooder supplements in which the ${ }^{131}$ I content is not repleniened by now fallout. Therefore, dairy cows ingest lene ${ }^{131}$ t than farm cows ingeet. This cosclusion is supported by fallout atudies of $\% \mathrm{~S}$ in farm and dairy milk conducted in Minnesota bundreds of kilometers from nuclear production facilitics (PHS, 1962).

During the periods of intermittent global fallout after 1963, the maximum ${ }^{211}$ I concentrations in local dairy and distributor millk were 240 and $330 \mathrm{pCi} / \mathrm{h}$, respectively. These cocurred in early 1967 after the Chinese teat on December 28, 1966. The maximum in the southenstern Pasteurized Milk Networt in early 1967 wa 114 pCi/L (PHS, 1967d). In milk farm cown, the maximum local concentration of 778 PCi/L was observed after the Chinese teat of September 26, 1976; this concentration is not consistent with the maximum concentration of $21 \mathrm{pCi} / \mathrm{L}$ in the southesstern Pasteurized Milk Network following this test (EPA, 1977b).

A difference between farm and dairy milk was also obeerved in the only sudy of I concentrations in milk near SRS. In general, milk from individual cown contained greater concentrations of 121 than mill from dairies (Hochel, 1976). The average 1201 concentration in dairy milk from within the $40 \mathrm{~km}$ radius is $0.06 \mathrm{pCi} /$. The maximum concentration observed is $9 \mathrm{pCi} / \mathrm{h}$ from an individual cow near the site perimeter. One reference states that the North American background concentration of ${ }^{12 \%}$ in milk is 0.006 pCi/L (Braver, 1974).

Network measurements indicate a smaller North American background value. During 1976-1978 2201 was measured in the Pesteurized Milk Network at two locations in the southeast-Montgomery, AL, and Charleston, SC. All but one of the 227 concentrations are leas than detection limits of approximately 0.001 PCi/L (EPA, 1977c; and EPA, 19796). The concentration in the May-June 1976 sample from Charleston was $0.0056 \mathrm{pCi} /$.

\section{Summary of Atmospheric Transport}

SRS releases and global fallout have been the principal sources of ${ }^{331} \mathrm{I}$ in various local environmental media. The years when SRS was judged to have been the principal source of ${ }^{131} I$ in the environment near SRS are shown in Table 4-5. The criterion for this judgment is a slope more negative (atceper) then -0.2 in the logarithmic plot of ${ }^{131}$ dat as a function of distance from SRS. Milk is not included in Table 45 because of an insufficient number of sampling locations to perform slope analysis.
Table 45. Years when SRS was the principal cource of ${ }^{131}$ I in various local offsite environmental media

\begin{tabular}{|c|c|c|c|}
\hline Year & Vegetation & Ralm & $\overline{\text { Ar }}$ \\
\hline $\begin{array}{l}1955 \\
1956 \\
1957 \\
1958 \\
1959 \\
1961 \\
1967 \\
1976 \\
1977\end{array}$ & $\begin{array}{l}\mathbf{X} \\
\mathbf{x} \\
\mathbf{X} \\
\mathbf{X}\end{array}$ & $\begin{array}{l}\mathbf{X} \\
\mathbf{X} \\
\mathbf{X} \\
\mathbf{X} \\
\mathbf{X} \\
\mathbf{X} \\
\mathbf{X}\end{array}$ & $\begin{array}{l}\mathbf{X} \\
\mathbf{X} \\
\mathbf{X} \\
\mathbf{X} \\
\mathbf{X} \\
\mathbf{X}\end{array}$ \\
\hline
\end{tabular}

Table 4-5 ahows that SRS releases had a aignificant impact on all three environmental media only in 1956, 1959, and 1961. SRS releases had an impect on only one or two of the modin in 1955, 1957, 1958, 1967, 1976, and 1977. Such behavior is expected because atmospheric releases of ${ }^{131}$ from SRS are not continuous; releases depend on specific operations underway in the separation facilities. Therefore, the detection of SRS ${ }^{131}$ I in vegetation depends on the timing of the periodic sample collections relative to recent SRS releases. Similarly, the detoction of SRS ${ }^{131} I$ in rain depends on the coincidence of rainfall with SRS releases.

The alope analysis shows that air, eoil, and vegetation bave slopes ateeper than -1.0 in come years. A slope stoeper than -1.0 indicates the effect of the iodine removal processes. These include gravity settling of particulate forms of radioiodine and physical and chemical interactions with vegetation, soil, and other features of the earth's aurface. Entrainment in rain apparently is not a major removal process on an annual besis; the slope for rain deposition does not exceed -0.9.

Maximum concentrations rather than annual average concentrations are used to assess the short-term impact of the scute release of ${ }^{131}$ I from SRS in 1961 . The maximum offeite concentrations in air, vegetation, and milk due to this incident range from a factor of 2 to 7 greater than the corresponding concentrations due to global fallout that cocurrod after 1963.

Low concentrations of 121 have been detected in air, vegetation, woil, and milk near SRS. The cumulative deposition pattern of ${ }^{12} I$ in the local terreatrial environment as of 1979 shows that SRS is the source of the ${ }^{22}$. The inventory in the focal terrestrial environment is consistent 
with the calculated releaser; this indicates that calculated releases probably were not undereatimated.

The terreatrial recults also show that foreated areas are more officient than open areas in removing 201 from the air.
Deposited ${ }^{20} \mathrm{I}$ is shown to be efficiently retained near the surface. These two observations are consintent with obcervations near other nuclear facilitios.

\section{Groundwater Transport}

The movement of rudionuclides in groundwater has been described in two fundamental aquations (Codell and Duguid, 1983). One equation deacribes the movement of the carrier fluid (water). The other equation describes the mass transport of diseolved conetituents (such as redionuclides). If the movement of the carrier in a given region is known, the distribution coefficient $\left(\mathbf{K}_{\mathbf{A}}\right)$ can be used to predict radionuclide transport.

The $\mathrm{K}$, for a given radionuclide is defined as the ratio of the setivity per unit mass of soil divided by the sctivity per unit volume of water in the soil. This relationship indicates that the semaller the $\mathrm{K}_{4}$ the more mobile the radionuclide is. Measured $\mathrm{K}$, values for a given radionuclide typically show a wide variability depending on factors such as soil particle size, wil characteristica, chemical form of the radionuclide, and water chemiatry (NCRP, 1984).

With a typical $K_{4}$ of 3.0, 201 has a mobility intermediate between tritium ( $K, 0$ of 0.001 ) which is very mobile and ${ }^{137} \mathrm{C}$ $\left(K_{1}\right.$ of 100$)$ which is not very mobile. Therefore, some migration of ${ }^{2} I$ in groundwater at SRS is expected.

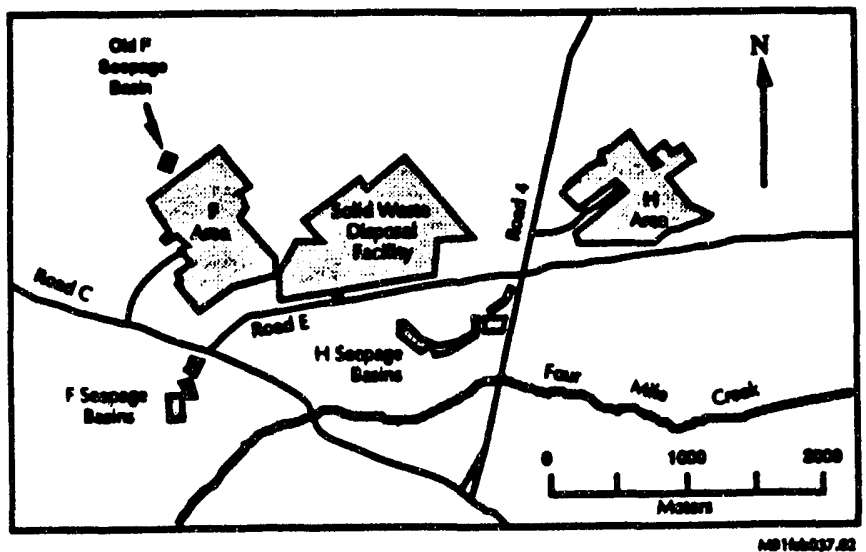

Figure 415. Locations of Waste Sites Near the Center of SRS

Sources of ${ }^{29} 1$ in groundwater are principally the effluents released to earthen seepage basins at the separations areas and the solids buried in the SWDF. These waste sites, which are shown in Figure 4-15, arose from past waste disposal practices that were consistent with general industry methoda. Use of the seepage basins in the separations areas was terminated in 1988.
The groundwater near these waste sites becomes contamianted with radioiodine when water percolates through the coil. In the SWDF, ninwater that percolates through the soil leaches radioiodine from certain buried wastes such as the spent cerrmic chipe conted with silver nitrate. In the ceepage banire siesolved radioiodine mignates with the percolating basin water. Oroundwater moves downward and horizontally and reaurfaces adjecant to site streams, principally Four Mile Creek. Because migration times from theae waste sites to the outcrops are measured in years, ${ }^{20} \mathrm{~T}$ is the only radiosetive isotope of iodine present in resurfaced water in measurable quantities.

A thonough description of the geological and hydrological charecteristics near the waste sites is presented in the reference Murphy et al., 1990.

\section{F-Area Seepage Basin System}

The F-Area Seepage Basins that were used from 1955 to 1988 are located south of F Area as shown in Figure 4-15. The Old F Area Seepage Basin, which was abandoned in 1955, is located north of $F$ Area. The basins are approximately $9 \mathrm{~km}$ from the nearest site boundary. The elevation of the basins is approximately 85 meters above sea level. The nearest major site streams to the F-Area Seepage Basins used nince 1955 are Four Mile Creek (600 meters to the southeast) and Upper Three Runs (1,600 meters to the northweat).

A limitod study of the 12 content of F Seepage Basin 3 was conducted in 1977-1978. Concentrations of ${ }^{121} I$ in monthly grab samples of besin water ranged from 50 to $300 \mathrm{pCi} / \mathrm{L}$ with an average of $160 \mathrm{pCi} / \mathrm{L}$ (Anderson, 1978; Kentelo, 1987). Month-to-month variations are attributed to rainfall and operational conditions in the separations process. The 
101 in a busin may remin in solution with the water in the barin, volutilize to the atmoephere, of be transported with the banis water as it migntes through the ground.

Because extensive data on the migration of redioiodine do not exist, tritium mignation data can be used to illustrate possible redioiodine movement. The travel time for tritium to migrate from the seepage basins to the outcrops adjacent to Four Mile Creek ranges from approximately 15 to 30 years (Murphy ef $\mathbf{a l}_{\text {., }} 1990$ ). Because the $\mathbf{K}_{\mathrm{a}}$ for iodine is greater than the $\mathbf{K}$ for tritium, jodine moves at a slower rate than tritium. Groundwater resurfaces along the seepline that is shown in Figure 4-16.
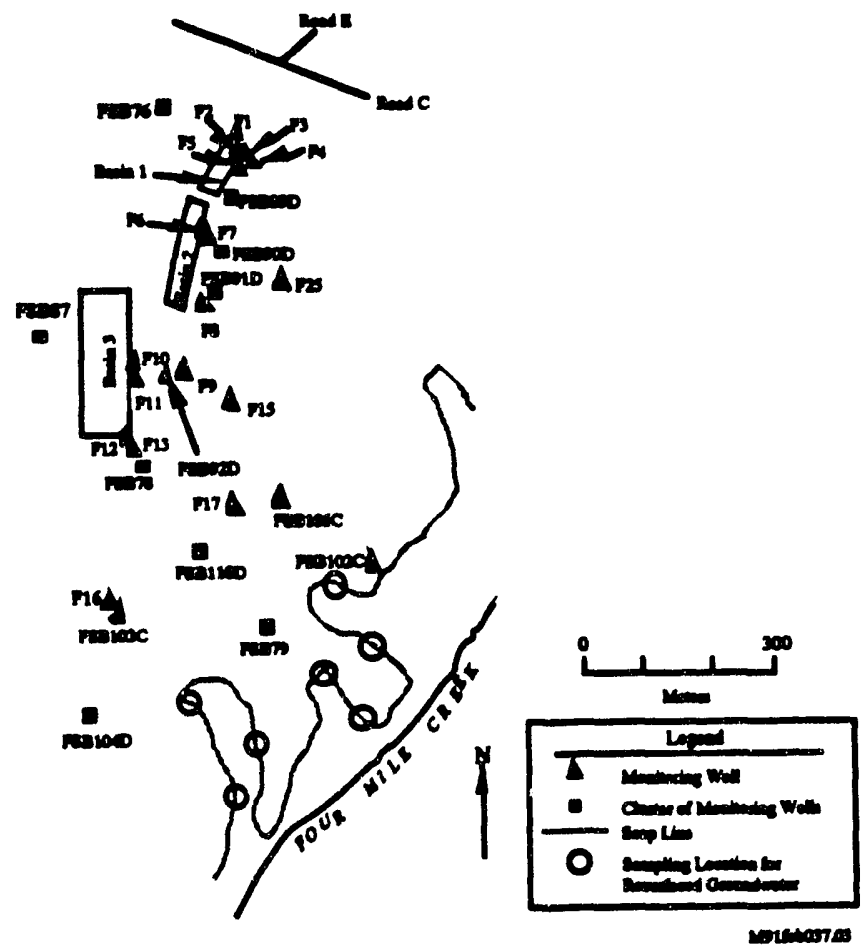

Ploure 4-16. Locations of Monitoring Wells Selected for Analysis of Radioiodine in Groundwater Near F-Area Seepage Barins

Although ${ }^{131}$ I has a short half life, its migration was detected in monitoring wells for perched water and the water table during the early years of operation. The locations of these wells, designated F1 through F13, are shown in Figure 4-16. The greatest concentrations were in the shallow wells closest to the seepage basins. The greateat annual average concentration of ${ }^{131}$ I was approximately $5 \times 10^{4}$ PCill in well F6 in 1956, the year of maximum aqueous releases to the F-Area Seepage Basins.
Migration of ${ }^{129}$ in groundwater at the F seepage basins was measured in 1977 when water table anples were analyzed by neutron activation analyais. In monitoring wells F15, F16, F17, and F25, ahown in Figure 4-16, concentrations of 12T ranged from 0.1 to 300 pCi/L (Anderson, 1978; Kantelo, 1987 ).

Routine analysis for ${ }^{12} 1$ using low energy photon spectroscopy began in 1989. Although it is less sensitive (detection limit of approximately $1 \mathrm{pCi} / \mathrm{L}$ ) than neutron sctivation andysis, it is more amenable to extensive routine andyees. Groundwater from 24 monitoring wells was analyzed for 121 several times during 1989. The locations of these wells, which have the letter designations "FSB", are shown in Figure 4-16. The individual wells of a well cluster are not shown. A well cluster consists of several monitoring wells, with each well typically collecting water in different geological formations. The progreasively deeper waters that were analyzed in 1989 are the water tuble, the McBean Member of the Santee Formation, the Upper Congaree Formation, and the Lower Congaree Formation.

At the water table depth, ${ }^{121}$ was detected in 8 of 9 wells. The average concentration is $80 \mathrm{pCi} / \mathrm{L}$ and the maximum is 290 pCi/L. In McBean 291 was detected in 5 of 7 wells at an averaze concentration of $60 \mathrm{pCi} / \mathrm{L}$ and a maximum of 140 $\mathrm{pCi} / \mathrm{L}$. No ${ }^{221}$ was detected in the eight wells of the Congaree formation, which is a minor source of drinking water at SRS.

The shallower Santee Formation is also a minor source of drinking water at SRS. The only SRS wells that draw drinking water from the Santee Formation are located in the $B$ and SRL areas, which are at least $5 \mathrm{~km}$ from the seepage basins (Figure 3-1, page 17). Although the concentrations oberved in the McBean Member of the Santee Formation near the F seepage basins exceed the EPA standand of 1 PCi/L for ${ }^{129}$ in drinking water (EPA, 1977d), the part of the Sentee Formation tapped for drinking water is not contaminated with 121 . This conclusion is based on the lack of elevated tritium concentrations in the drinking water; ${ }^{120}$ I concentrations in McBean are asacciated with tritium concentrations that are a factor of approximately $10^{5}$ greater. The source of the drinking water is not likely to become contaminated because the contaminated groundwater flows in the opposite direction toward Four Mile Creek. Furthermore, Upper Three Runs Creek cuts through the Santee Formation to phycically isolate the two portions of the formation. This is shown in Figure $4-17$, which is based on the reference Andland and Bledeoe, 1990. 
Fugure 417. Hydrogeologic Profile Along a Straight Line Comecting the F-Area Seepage Basins and B Area (SRL is Offeet from the Libe; aleo, Soe Figure 3-1)

Groundwater resurfeces at outcrope along a seepline adjacent to Four Mile Creek at an elevation approximately 20 meters lower than the elevation of the basins. The location of the seepline is shown in Figure 416.

The firet meacurement of ${ }^{121}$ in outerop water was in 1977. The 201 concentration in a grab sample was $224 \mathrm{pCi} /$ (Anderson, 1978). In 1988 and 1989, a comprehensive survey for numerous radionuclides, including $2 \%$, was conducted along the seepline; Figure 4-16 shows moet of the locations sampled close to the besine. Coscentrations of 21 in grab samples of resurficed grounctwater ranged from 24 to $3415 \mathrm{PCi} /$ in 1988 , and from leas than 23 (detection limit) to 410 pCil in 1989 (Heselow a al., 1990).

The outcrop results for 1977, 1988, and 1989 are not directly comparable because sampling locations are not the same in each year. The reaulis only show that the elevated concentrations of ${ }^{21} \mathrm{I}$ in outcrop water are in the hundreds of $\mathrm{pCi} / \mathrm{L}$. These concentrations are consistent with the concentrations observed in the groundwater monitoring wells.

Mout of the groundwater samples analyzed for ${ }^{25}$ I were aleo analyzed for tritium. Figure 4-18 shows the concentrations of 21 plotted againat the corresponding tritium concentrations. Groundwater 121 concentrations are anocinted with tritium coscentrations that are greater by a factor of $10^{5}$ to 10. The correlation of ${ }^{2} 1$ and tritium concentrations is

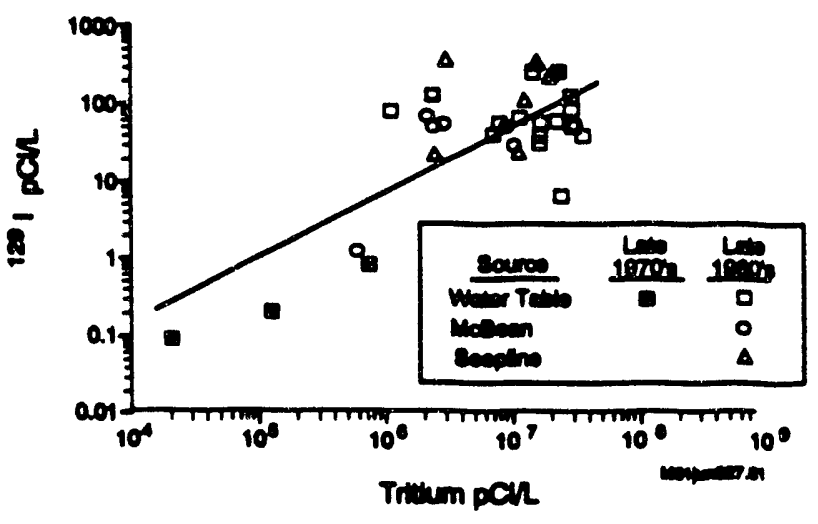

Pagre 418. Correlation of ${ }^{201}$ and Tritium Concentrations in the Groundwater Near the F-Area Seepage Basins

shown by the regreasion line through the data. The slope of the line is 0.81 , which means for every doubling of tritium concentration, the 121 concentration increases a factor of 1.8.

Sodiments in the path of the migrating barin water aleo show evidence of 12 . Sedimeat cores thiken inside the F-Area seepage basins in 1984 show a maximum concentration of $120 \mathrm{pCi} / \mathrm{g}$ (Corbo of al., 1985). The vertical profile of 21 concentrations can not be determined because only the top and bottom of the cores were analyzed for ${ }^{22} I_{i}$ this provides only two data points for the vertical profile.

Sediments cores were taken along the reepline in 1988 and 1989. Concentration of ${ }^{211}$ in sediments from various depth intervals range from 1 to $5 \mathrm{pCi} / \mathrm{g}$ in 1988 and are leas than detection limits of approximately $5 \mathrm{PCi} / \mathrm{g}$ in 1989 (Hacelow at al., 1990). (Beceuse detoction limits are not fixed values, it is poacible to meature $1 \mathrm{pCi} / \mathrm{g}$ in one set of amlyees and have a detection limit of $5 \mathrm{pCi} / \mathrm{g}$ in another set.) Coring boations are not the same in each year.

Sodiment cores were taken from intide the abandoned Old F-Area Seepage Barin in 1986 to study migration of radionuclidar. Sections from various depth imtervals in four banin-ediment cores were individually analyzed for $12 \%$. The maximum concentration is 3 pCi/g (Shedrow, 1986). Vertical profiles of 11 concentrations show no consistent pattern. In two cores $2 \mathrm{I}$ is atill detected at the bottom of the 400 -en deep corea. In the other two corea, the $1 \%$ content is below the detection limit of approximately $0.3 \mathrm{pCi} / \mathrm{g}$ beginning at depths of 100 and $300 \mathrm{~cm}$. 


\section{H-Area Seepage Basin System}

The H-Area Seepage Basins are located southweet of $\mathbf{H}$ Area (see Figure 4-15). The basins are about $11 \mathrm{~km}$ from the neareat aite boundary and bave an elevation of approximately 75 meters abovo sea level. The nearest major site streams are Four Mile Creek, which is $\mathbf{3 0 0}$ meters to the soutbeast, and Crouch Branch (a tributary of Upper Three Runs Croek), which is 1,100 meters to the north.

A limited atudy of the I content of H-Seepage Basin 4 was conducted in 1977-1978. Concentrations of ${ }^{220} \mathrm{I}$ in monthly grab samples of basin water nanged from 15 to $80 \mathrm{pCi} / \mathrm{L}$, with an everage of $46 \mathrm{pCi} /$ (Andereon, 1978; Kantelo, 1987). As described for the $F$ seepage basin system, month-to-month variations are attributed to rainfall and operational conditions in the reparations process. Also, tritium migration data can be used to illustrate possible ${ }^{12} / 1$ migration. The travel time for tritium to mignate from the seepage basins to Four Mile Creek nanges from 14 to more then 50 years (Murphy et. al, 1990). Groundwater resurfaces along the seepline shown in Figure 4-19.

Migration of ${ }^{131}$ I was detected in monitoring wells for the water table during the early years of operation. The locations of these water table wells, designated H1 through H8, are shown in Figure 4-19. The greatest annual average concentration of ${ }^{131} \mathrm{I}$ was approximately $3 \times 10^{6} \mathrm{pCi} / \mathrm{L}$ in well HS in 1956.

Migration of 121 in groundwater at the $H$ Seepage Basins was measured in 1977 when water table samples were analyzed. In monitoring wells H13, H14, H15, H18, and H19, sbown in Figure 4-19, concentrations of ${ }^{221}$ ranged from 0.1 to $16 \mathrm{pCi} / \mathrm{L}$ (Anderson, 1978; Kantelo 1987). An ${ }^{129} \mathrm{I}$ concentration of $63 \mathrm{pCi} / \mathrm{L}$ was measured in 1980 for the water table monitoring well BG10 adjacent to basin 4 (Kantelo, 1987). This is the maximum ${ }^{129} 1$ concentration detected in the groundwater near the H-Area Seepage Basins.

Groundwater from 19 monitoring wells was analyzed for 120 I several times during 1989. The locations of these wells, which have the letter designations "HSB", are shown in Figure 4-19. The progressively deeper waters that were analyzed in 1989 were the water table, the Upper Congaree Formation, and the Lower Congaree Formation. At the water table depth, ${ }^{12} / \mathrm{was}$ detected in 13 of 16 wells. The everage concentration is $14 \mathrm{pCi} / \mathrm{L}$ and the maximum is 50 pCi/L. No ${ }^{220}$ was detected in the three wells for the Congaree Formation.

Groundwater resurfaces along a seepline adjecent to Four Mile Croek af an elevation approximately 15 meters lower

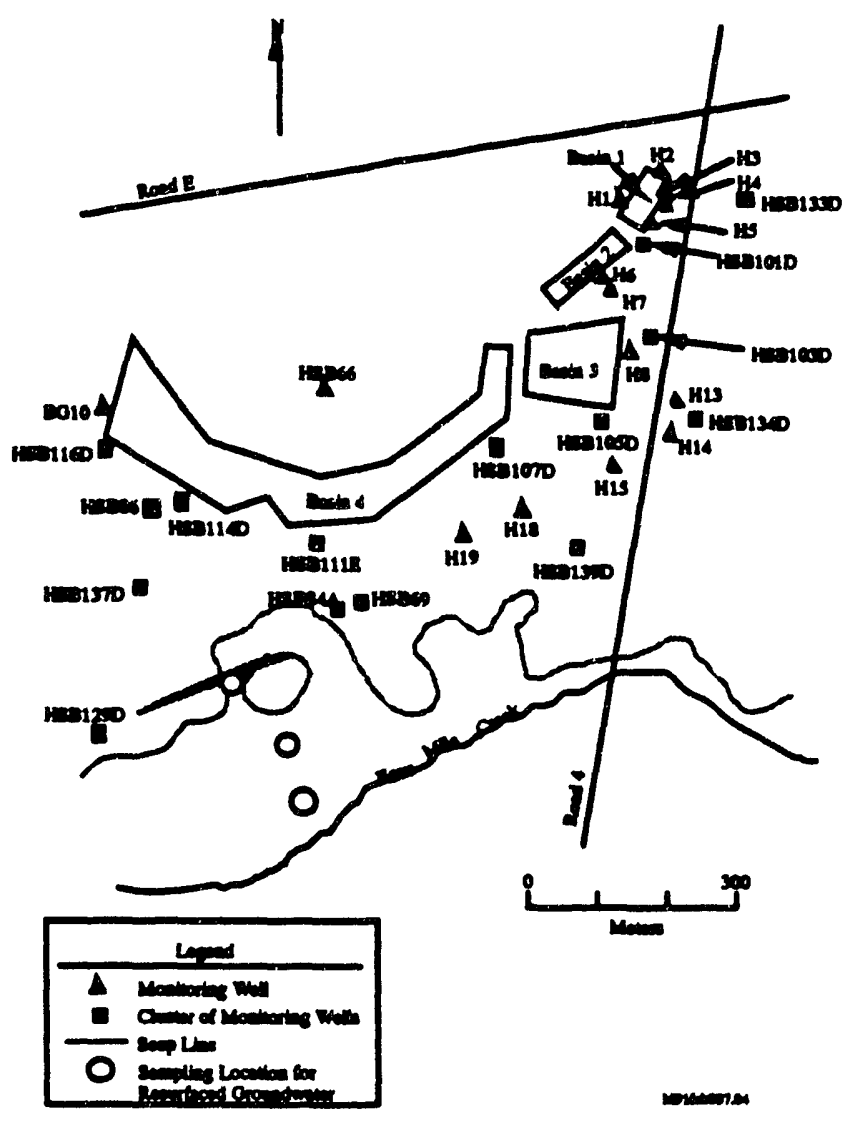

Higure 4-19. Locations of Monitoring Wells Selected for Analysis of Redioiadine in Groundwater Near H-Area Seepage Basins

than the elevation of the basins. The location of the seepline is shown in Figure 4-19. Concentrations of ${ }^{129}$ in grab samples of resurfaced groundwater at two locations along the seepline were 5 and $50 \mathrm{pCi} / \mathrm{L}$ in 1988, and were below detection limits of approximately $50 \mathrm{pCi} / \mathrm{L}$ at five locations in 1989 (Haselow et al., 1990). Figure 4-19 shows the locations sampled close to the basins.

The outcrop results for 1988 and 1989 are not directly comparable because sampling locations are not the same in each year. The results only show that the elevated concentrations of ${ }^{12} \mathrm{I}$ in outcrop water are in the tens of $\mathrm{PCi} / \mathrm{L}$. These concentrations are consistent with the obeerved concentrations in the groundwater monitoring wells and are an order of magnitude lower than the results for the P-Area seepage basin system.

Figure 4-20 shows concentrations of ${ }^{12} 1$ plotted against corresponding tritium concentrations. Groundwater $22 \%$ concentrations are associated with tritium concentrations 
that are greater by a factor of $10^{\circ}$ to $10^{\circ}$. The correlation of 20I and tritium concentrations is shown by the regreasion line through the data. The slope of the line is 0.73 , which is not as steep as the slope of 0.81 for the groundwater data near the F-Area seepare basine. The difference is meaninglese because insufficient dats exists at the lower concentrations to determine preciec alopes for the data in Figures 4-18 and 4-20.

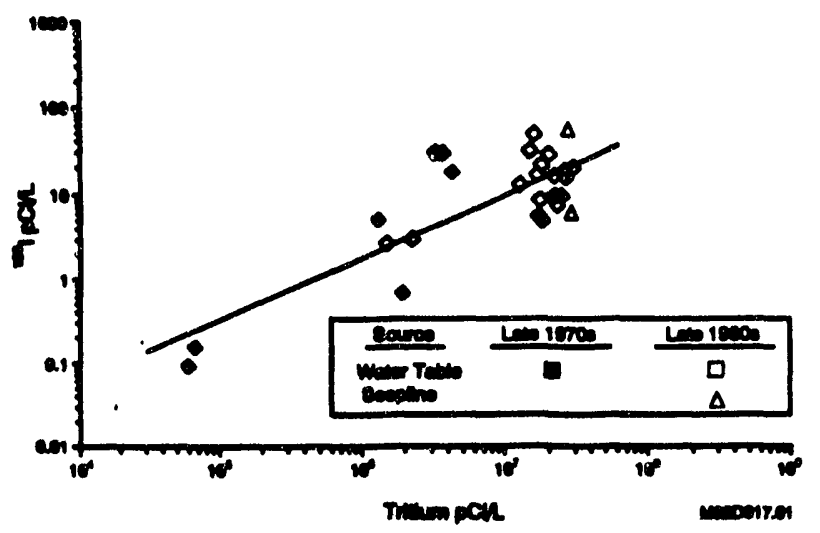

Figure 420. Correlation of 221 and Tritium Concentrations in the Groundwater Near the H-Area Seepage Basins

An incorrect tritium concentration of $1.6 \times 10^{5} \mathrm{pCi} / \mathrm{ml}$ on May 23, 1989 is reported for monitoring well HSB116D in the 1989 annual environmental report. The correct value is $1.5 \times 10^{\circ} \mathrm{pCi} / \mathrm{ml}$ (EMS, 1989a and EMS, 1989). The correct value, converted to units of $\mathrm{PCi} / \mathrm{h}$, appears in Figure 4-20.

Sediments in the path of the migrating besin water also show evidence of ${ }^{20 \%}$. Sediment cores taken from H-Area Seepage Basins in 1984 show a maximum concentration of $190 \mathrm{pCi} / \mathrm{g}$ (Corbo et al., 1985).

Sediment cores have also been taken along the seeplines. Concentrations of 1291 in sediments from various depth intervals range from 1 to $5 \mathrm{pCi} / \mathrm{g}$ in 1988 and are less than detection limits of approximately $5 \mathrm{pCi} / \mathrm{g}$ in 1989 (Haselow et al., 1990). Coring locations are not the sume each year.

\section{Solid Waste Disposal Facility}

The SWDF, which is located between F and H Areas (see Figure 4-15), is approximately $10 \mathrm{~km}$ from the nearest site boundary and has an elevation of approximately 88 meters above sea level. The nearest major site streams are Four Mile Creek, which is 900 meters to the south, and Crouch Branch, which is 700 meters to the north. The horizontal
How of groundwater beneath the SWDF is divided between southerly flow toward Four Mile Creek and northeriy flow toward Upper Three Runs Croek.

Tritium migration dath can be usod to illuatrate possible ${ }^{221}$ migration. The travel time for tritium migration from the SWDF to Four Mile Creek ranges from 11 to 50 years. The travel times to Upper Three Rums Creek are considerably longer; eacentially all the tritium (12-year half-life) is expected to decay before outcropping (Murphy at al, 1990).

The principal source of ${ }^{20} /$ buried in the SWDF is epent ceramic chips that were used for radioiodine removal during diseolution of irrediated materials. The presumed chemical form of 1 on the chips is silver iodide, which is only very slightly soluble in water.

An experimental atudy of the leachability of ${ }^{22} 1$ from buried chips demonstrates that a small fraction, $1.8 \times 10^{-7}(0.18$ parts per million), is leachable from the waste (Hawkins, 1983). This fraction wes relatively constant on an annual banis during the four-year study, although the leachable fraction for individual amples during a given year fluctuatod with the quantity of rinfall. This small leachable frection is consistent with the very slight solubility of silver iodide. The leached iodine is expectod to exist in the iodide chemical form in groundwater.

An experimental determination of the distribution coefficient for ${ }^{12} T$ in 20 il from the SWDF showe that $K_{4}$ ranges from 3.6 to 10 depending on the concentration of atable iodine. Smaller $\boldsymbol{K}$ values are aseociated with the greater stable iodine concentrations. With a $\mathbf{K}$ of $3.6,{ }^{22 \%}$ is prodicted to move at 5 percent of the groundwater velocity (Hoeffner, 1985).

Until 1989 only limited anslyse were performed to determine the extent of ${ }^{12} / \mathrm{migratins}$ from the SWDF. The monitoring well PDQS was of particular interest in the earlier studies. This well is $\mathbf{1 8 0}$ meters from the south boundary of the SWDP (coe Figure 4-21). It has a 2-meter screen at the 14-meter depth, which corresponds to the middle of the of migrating tritium plume. Concentrations of 127 in well PDQ5 increased from $0.25 \mathrm{pCi} / \mathrm{L}$ in April 1982 to $15 \mathrm{pCi} / \mathrm{L}$ in December 1982 to $12 \mathrm{pCi} / \mathrm{L}$ in Auguat 1983 (Obiath, 1986). These limited results demonstrate the arrival of the leading edge of migrating 121 . The concentration of tritium is approximately $10^{\circ}$ greater than the ${ }^{120}$ concentration in the Auguat 1983 sample. The 221 concentration is leas than the detoction limit of 7 pli/L in 1987 (McIntyre and Wilhite, 1988). 
Mearumble concentration of 12 were detected in groundwater from monitoring wells BG56, BG57, BGC3C, I13, and BOC2C alons the wouth boundary of the SWDF in 1979,1980 , and 1983. Concentrations are no greater than 0.03 pCi/ with the erception of well BCC3C, which has a concentration of 0.9 pCi/ (Kantelo, 1987). The tritium concentration exceed the 1201 concentration by factors of $10^{7}$ to $10^{8}$ in the August 1983 samples. The purpose of wells BGC3C and BGC2C is to determine the depth and bresdth of the migrating tritium plume. The other wells are water table wells.

Groundwater from 19 monitoring well was andyzed ceverd times during 1989. The locations of these wells, which have the letter deaignation "BCO" and "HSB", are shown in Figure 4-21. The progreasively deeper waters andyzed in 1989 were the water table (9 wells), the McBean Member of the Suntee Formation (7 wells), and the Conguree Formation ( 3 wells). No ${ }^{12} 1$ was detected in the water amples from these 19 wells at a detection limit of approximntely 1 pCi/L. The 1989 reaults are consistent with the earlier studies; monitoring well PDQS was not sampled in 1989.
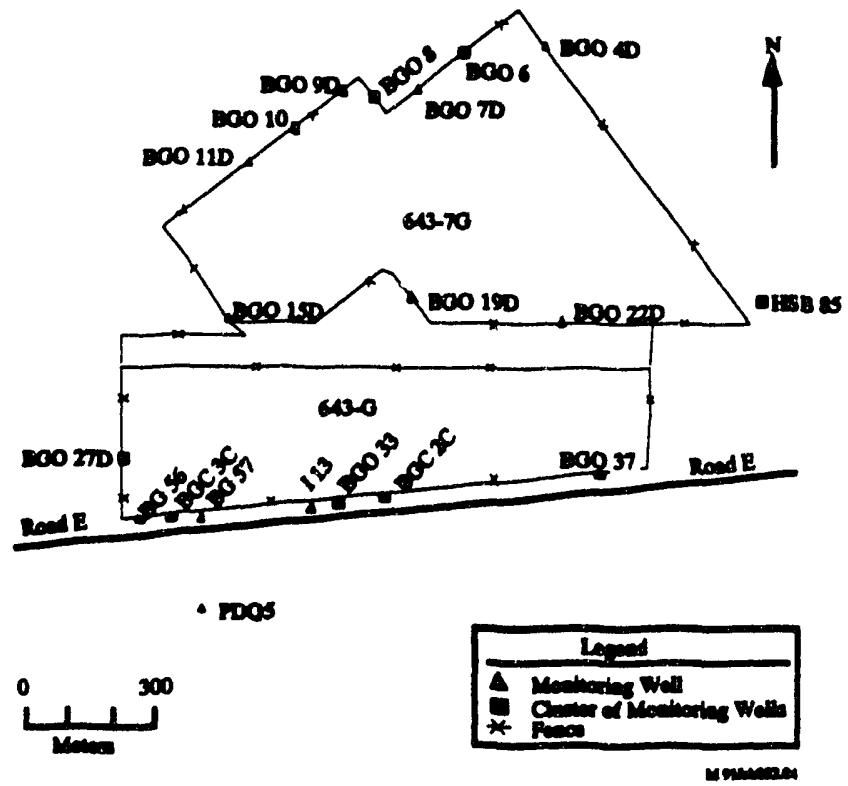

Doure 4-21. Locations of Monitoring Wells Selected for Andyais of Radioiodine in Groundwater Near SWDF

\section{Surface Water Transport}

The proximity of major site streams to SRS facilities involved with radioiodine is shown in Figure 3-1 (see page 17). The major streams are tributaries of the Savannah River, which flows to the Atlantic Ocean. One small unnamed strenm in the northeastern sector of the site drains to the east into the Salkehatchie River. No effluent from SRS facilities drains into this unnamed stream, which is not shown in Figure 3-1.

\section{Surface Waters at SRS}

The principal sources of the natural flow in site streams are springs and rainfall. Cooling water from SRS resctors and other SRS processes augments the matural flow in certain streams. The majority of radioiodine transported by site surfece waters originates in direct aqueous releases from SRS facilities or migration from separations area scepage besins and the SWDF. A minor source is minwater runoff, which transports part of the radioiodine deposited from SRS atriospheric releases and global fallout.

Upper Three Rum Creek is the only site stream that originates offsite. It is $40 \mathrm{~km}$ long, has a waterahed of sbout $540 \mathrm{~km}^{2}$, and an average natural flow rate of approximately $7 \mathrm{~m}^{3} / \mathrm{sec}$. One of its principal tributaries is Tim's Branch, which receives effluents from $M$ Ares and SRL. These effluents add approximately $0.3 \mathrm{~m}^{3} / \mathrm{sec}$ to the flow rate of Upper Three Runs Creek. The Effluent Treatment Facility in H-Area began discharging treated water to Upper Three Rum Croek in 1988.
Beaver Dam Creek is the smalleat of the SRS xtreams that drain into the Savannah River. Its length is about $5 \mathrm{~km}$ and its waterabed is about $26 \mathrm{~cm}^{2}$. Beaver Dam Creek receives approximately $3 \mathrm{~m}^{3} / \mathrm{sec}$ from $D$ Area effluents. In the Savannah River swamp, overflow from Four Mile Creek mixed with Beaver Dam Creek when C Reactor discharged secondary cooling water.

Four Mile Creek is approximately $24 \mathrm{~km}$ long and has a waterabed of about $57 \mathrm{~km}^{2}$. Its natural flow is $0.14 \mathrm{~m}^{3} / \mathrm{sec}$. It receives effluent from the $F$ and $H$ chemical separations areas and migrating water from the SWDF and F- and H-Area Seepage Basine. Bffluent from the chemical separations areas adds approximately $0.3 \mathrm{~m} / \mathrm{sec}$. Until the mid 1980s the lower reaches of Four Mile Creek received secondary cooling water from C Resctor. Cooling water added a flow of approximntely $11 \mathrm{~m}^{3} / \mathrm{sec}$ when the resctor was operating. Miscellaneous C-Area discharges added spproximately $0.14 \mathrm{~m}^{3} / \mathrm{sec}$. 
Pen Branch flows approximately $24 \mathrm{~km}$ to the Savannah River swamp where it flow path becomes relatively undefined. It generally flows through the swamp parallel to the river for about $8 \mathrm{~km}$ before entering Steel Creek near its confluence with the Savannah River. Pen Branch has a waterabed of about $55 \mathrm{~km}^{3}$. Its natural flow rate of 0.2 $\mathrm{m}^{3} / \mathrm{sec}$ increasen to about $11 \mathrm{~m}^{3} / \mathrm{sec}$ when $\mathrm{K}$ Resctor discharges eocondary cooling water.

Stcel Croek is approximately $18 \mathrm{~km}$ long and has a waterabed of about $90 \mathrm{~km}^{2}$. Flow rates vary depending on reactor effluenth. For example the flow was $22 \mathrm{~m}^{3} / \mathrm{sec}$ when both $P$ and L Reactors discharged aqueous effluents to Stoel Creek in the early $1960 \mathrm{~m}, 0.7 \mathrm{~m}^{3} / \mathrm{sec}$ for moet of the $1970 \mathrm{~m}$, and $11 \mathrm{~m}^{3} / 20 c$ in 1985 after the restart of L Reactor. A large impoundment, L Lake, was formed by damming Steel Creek south of L Resctor in the mid 1980 .

Lower Three Runs Creek has the second greatest drainage area $\left(150 \mathrm{~km}^{2}\right)$ of the SRS streams. Both $\mathrm{P}$ and $R$ Reactors discharged efflivents to the Lower Three Runs Creek syatem. In the upper reaches of the creek a large impoundment, Par Pond, was constructed in 1958 to provide cooling water for recirculation through $P$ and $R$ Reactors. Several amaller ponds were constructed between the reactore and $P$ ar Pond to provide cooling for resctor effluents reentering Par Pond. The average flow rate from Par Pond into Lower Three Runs Creek is $1 \mathrm{~m}^{3} / 20 c$. From the Par Pond dam, Lower Three Runs Creek flows approximately 38 kilometers to the Savannah River. For most of this distance the creek is outside the main part of the site; however, the creek is bordered by a narrow strip of SRS-owned land.

Site steams, other than Upper Three Runs Creek and Lower Three Runs Creek, pass through an extensive swamp along the South Carolina side of the Savannah River. The swamp typically floods at least one day during every month of the year (Marter, 1974). The most frequent flooding occurs in January through April and the annual average flooding is 23 percent of the year.

When flooding occurs, the flow in the Savannah River swamp generally runs parallel to the river and does not enter the main channel until high ground is encountered approximately $10 \mathrm{~km}$ downriver from Steel Creek. This condition allows mixing of water from site streams with the water in the flood plain.

Figure 4-22 shows the annual average concentrations of ${ }^{131}$ I measured in the SRS surface water. No. ${ }^{231}$ I has been detocted in Upper Three Runs Creek, Beaver Dam Creek, or the swamp. The concentration in Four Mile Creek during 1962 was below the detection limit. No annual average ${ }^{131}$

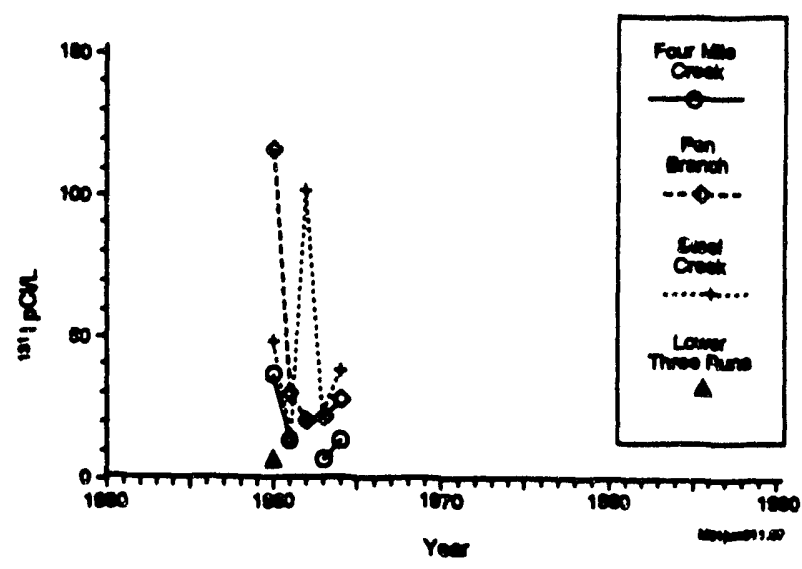

Togare 4-22. Annual Average Concentrations of ${ }^{211}$ in SRS Streams from 1960 through 1989

recults were reported before 1960 or during 1965-1977; concentrations have been below detection limits afier 1977 .

The greatest annual average ${ }^{131}$ I concentrations are aseociated with fuel element failures in the reactor. These concentrations were $116 \mathrm{pCi} / \mathrm{L}$ in Pen Branch during 1960 and $102 \mathrm{pCi} / \mathrm{L}$ in Stoel Croek during 1962. The greateat ${ }^{131}$ concentration in an individual sample of stream water wes 22,000 pli $/$, which was obeerved in Sloel Creek following a fuel element failure in P Reactor in 1957.

Surveys to determine 120 concentrations in grab samples of site streams and swamp waters were conducted in Auguat 1977 and June 1978 (Andereon, 1978; Anderson, 1980; Kantelo, 1987). Concentrations for a given stream in the two surveys generally agree within a factor of two. This difference is not considered significant because concentrations depend on flow conditions, which were not documented at the time of sampling. The 1978 survey reaults are shown in Figure 4-23.

Local beckground concentrations of ${ }^{221}$ were approximately $0.001 \mathrm{pCi} / L$, as shown by the values in Lower Three Runa Creek and the Savannah River upriver from SRS. This local beckground is approximately 100 times greater than the North American river water beckground, which is on the order of $10^{-5} \mathrm{PCi} / \mathrm{L}$ (Bruver, 1974). The local background in streams is elevated because of the deposition of sirborne SRS ${ }^{2} I$ oato the terreatrial eavironment. Rainfall runoff leaches part of the depoeited 127 and transports it to the streams.

Concentrations in Upper Three Runs Croek-the stream with the largent wateribed-are approximately twice the local background. This is because the proximity of Upper 


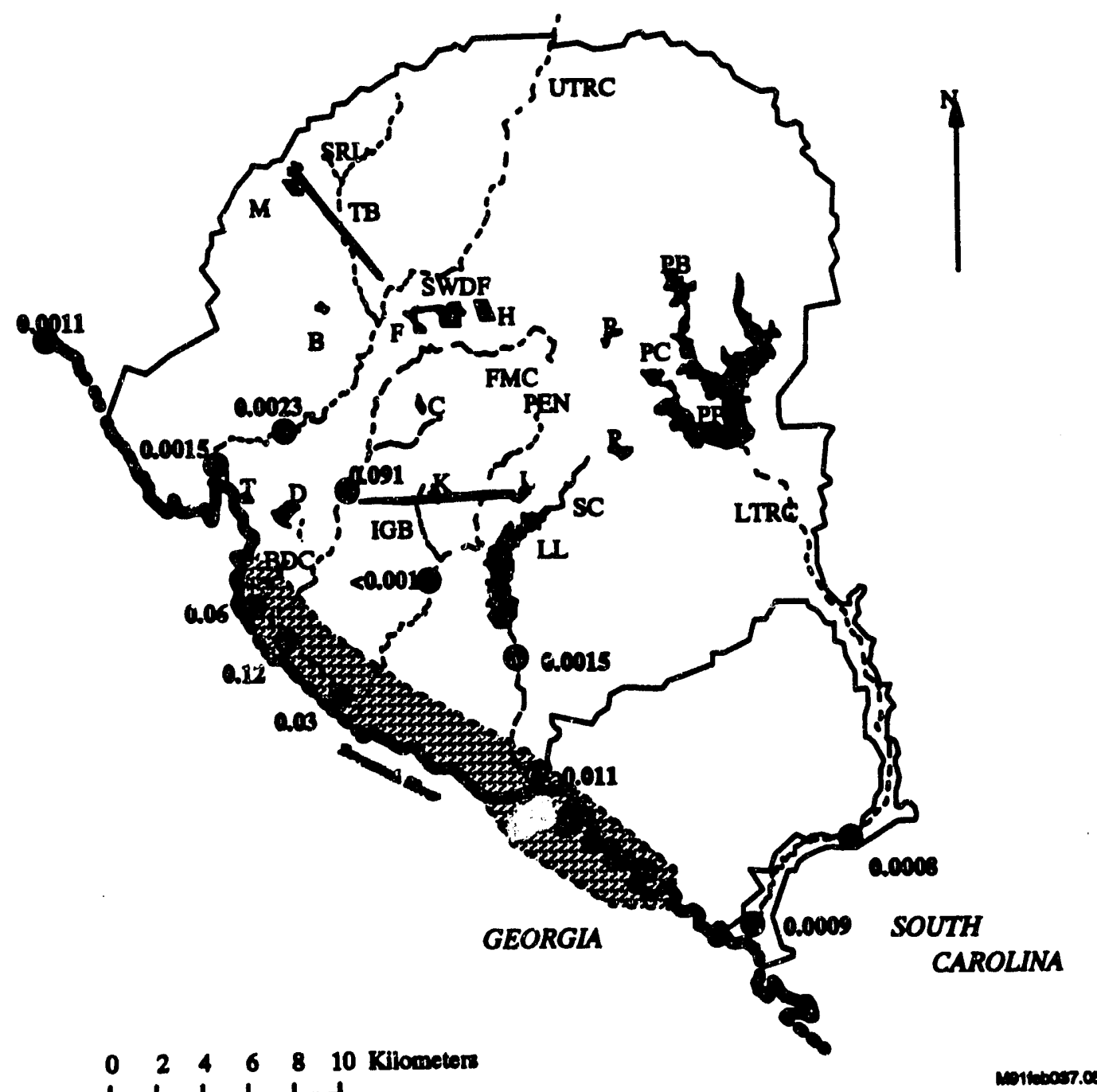

Facilities Lesend

\begin{aligned} & \hline B HWCTR \\ & C,K,L,P,R Resctor Areas \\ & D Heavy Water \\ & F Chemical Separations + Naval Fuels \\ & H Chemical Separations + RBOF \\ & M Raw Materials \\ & SRL Savannah River Laboratory \\ & SWDF Solid Wale Diepoeal Facility \\ & T TNX Semi Worts \end{aligned}

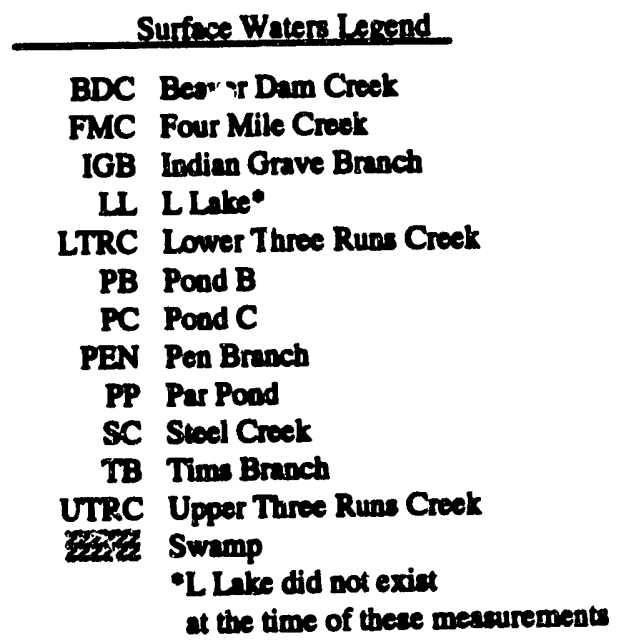

Figure 4-23. Concentrations of ${ }^{12} \mathrm{I}$ ( $\left.\mathrm{pCi} / \mathrm{L}\right)$ in SRS Streams and the Savannah River Swamp in 1978 
Three Run Creak to the cepantions arens results in grenter deposition in its waterised then in the other watersheds. Cilculations show thet the elevated ${ }^{20} 1$ in Upper Three Runs Creek does not originte from spontnneous fission of SRS uranium dispersed into the sediments of Tim's Branch. Although tons of unirradinted uranium have been dispersed, the quantity of uranium cannot produce enough ${ }^{120} 1$ by spontuneous fision to sccount for the elevated concentretions.

The greateat 1 concentrations are in Four Mile Creek and in the swamp impacted by Four Mile Creak. These concentrations are approximately 100 times greater than the locel beckeround. The elevated concentrations are principally due to migration of 201 from the separtions area seepage bessins.

Four Mile Creek has been studied more than any other stream. Grab anmples downstream of the outcrops from F-Area seepage basins but upstream of the confluence with C-Reactor effluent, showed concentrations of 33 and 2 Fi/L in 1973 and 1977, respectively (Kantelo, 1987). In 1988 the concentrations were below the detection limit of 1 pCill (Haselow et al, 1990).

Sampling of Four Mile Creek in 1977, 1979, and 1980 between the outcrope from F- and H-Area seepage basins showed 129 concentrations of approximately $1 \mathrm{pCi} / \mathrm{L}$ (Kantelo, 1987). In 1988 the concentrations were below the detection limit of $1 \mathrm{pCi} / \mathrm{L}$ (Haselow, of a., 1990).

Although a simultaneous sampling of Four Mile Creek upstream and downstream of the outcrope from F-Area seepage basins has not been not performed, the limited results obtained in the 1970 s suggest that the majority of ${ }^{12} 1$ in Four Mile Creek originates in the F-Area seepage basina. That conclusion is supported by the 1977, 1988, and 1989 groundwater results along the seeplines if it is assumed that the input rate of ${ }^{129}$ to Four Mile Creek from the outerops near the H-Area seepage basins does not exceed the input rate from the outcrops near the F-Area seepage basins.

Sediments from site atreams and the Savannah River swamp have periodically been analyzed. Gamma spectrometric a'nlysis ias not revealed any detcetable ${ }^{231}$ I. A compreben. sive survey of sediments for numerous radionuclides, including ${ }^{12} \mathrm{~L}$, was conducted in the mid 1980s (Lower, 1987). Sediment cores were taken to a depth of $100 \mathrm{~cm}$. A composite sample of the entire core for each sampling location was analyzed. Results of ${ }^{12} 1$ analyses are shown in Figure 4-24.

Concentrations of ${ }^{129}$ generally are at the detection limit of $0.1 \mathrm{pCi} / \mathrm{g}$ or within a factor of two of it. The gratest sediment concentrutions of ${ }^{29} I$ are in Four Mile Creek and the ewamp impected by Four Mile Creek. These concentrntions are approximately 5 times grenter then the detection limit. The elevated concentrations principally are caused by 120 that migrates from the separations area seepage basin and adsorbs on the sediments.

Despite the history of multi-curie releases of short-lived ${ }^{131}$ I to Steel Creek, greatly elevated concentrations of ${ }^{229} 1$ were not detected. This is becuse the high activity ${ }^{131}$ I releases were associated with fnilures of freshly irradiated fucl elements; the ${ }^{20} 1$ content of the releases was extremely amall (Table 2-1; page 10).

A significant portion of any ${ }^{129}$ absorbed on sediments in Steel Creek wes probably leached by the hot secondary coolant effluent from $L$ and $P$ resctor. This condition also applies to Pen Branch and K. Renctor, although an elevated concentration of $0.36 \mathrm{pCV} / \mathrm{s}$ wes detected in Pen Branch.

The rewults for Four Mile Creak may also indicate the effect. of hot water leaching. The factor of three difference in 201 concentrations upstream and downetream of the confluence with effluent from C-Resctor may be related to leaching of iodine from sediments by bot water.

The lack of extensive sampling and analyees for 201 limits conclusions to the generalities stated in this section on SRS eurfince water.

\section{Savannah River}

The Savannab River forms the southweatern SRS site boundary for about $33 \mathrm{~km}$. It has an average flow rate that increases from $285 \mathrm{~m} / \mathrm{sec}$ upriver from SRS near Augusth, GA, to $340 \mathrm{~m}^{3} / \mathrm{sec}$ downriver near Clyo, GA. The upriver and downriver locations are approximately 300 and 100 river-kilometers, respectively, from the Allantic Ocenn. SRS is located between 261 and 228 river-kilometers from the Atlantic Ocenn.

SRS has three pump stations on the river. Two supply cooling water for the production resctors while the third applies cooling and process water for D Area. Except fror evaporative loses, all river water is returned to the Savannah River.

The annual average concentrations of ${ }^{131}$ I in Savannah River water at Highway 301 Bridge, approximately $37 \mathrm{~km}$ downriver from Steel Creek, are shown in Figure 4-25. Concentrations prior to 1960 were not messured. The plotted concentrution is the net concentration, which is the difference hetween mensured concentrations at Highway 


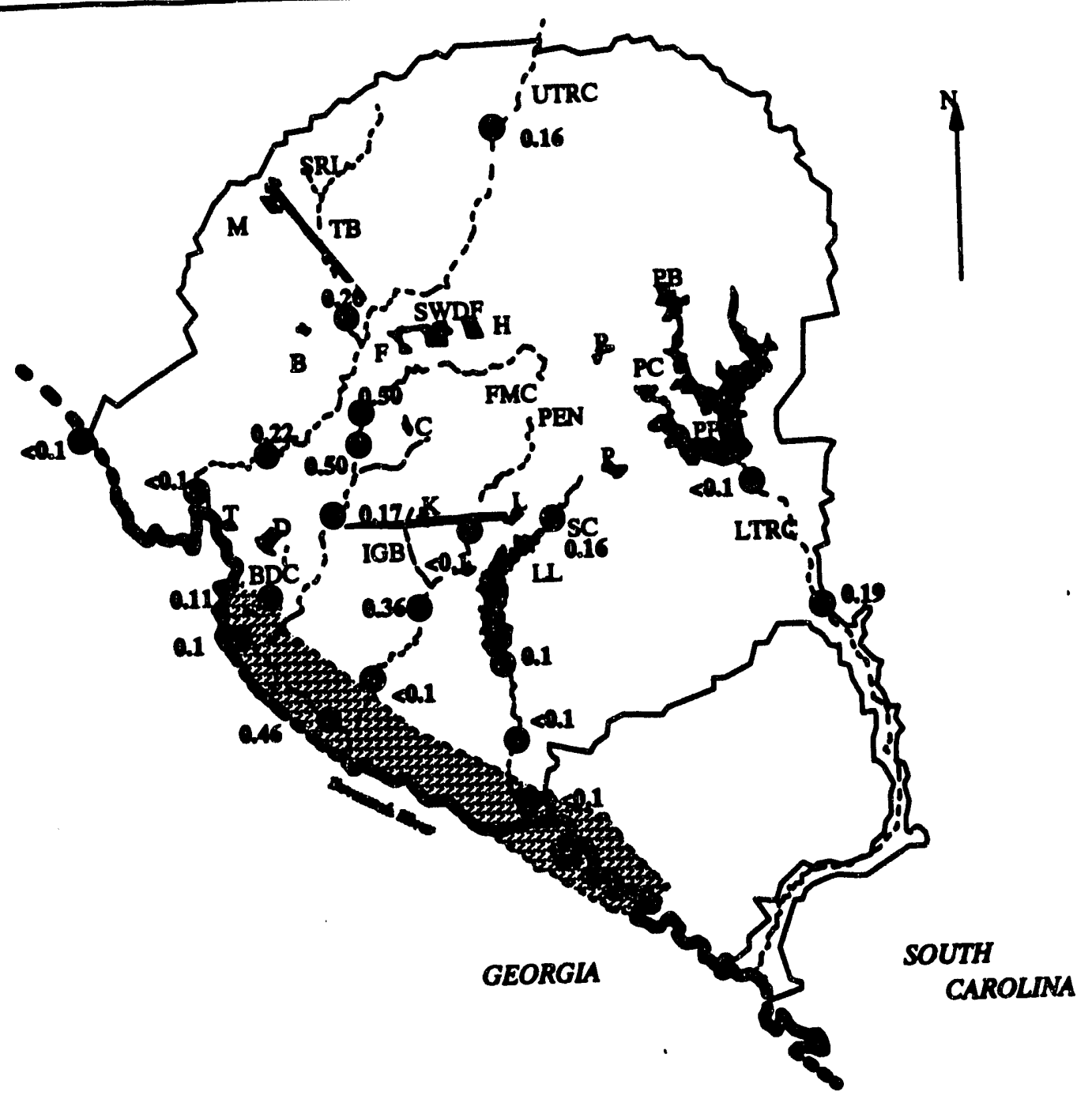

$\begin{array}{llllll}0 & 246 & 8 & 10 & \text { Kilometers }\end{array}$

mertost.09

Fecillities Legend

B HWCTR

C,K, $, \mathbf{P}, \mathbf{R}$ Renctor Areas

D Heavy Water

F Chemical Sepantions + Naval Fuels

H Chemical Separations + RBOF

M Row Materials

SRL Savanma River Laboratory

SWDF Solid Wate Dimpan Fecility

T TNX Semi Worto
Surfoce Waters Legend

BDC Beaver Dam Crook

FMC Pour Mile Croek

IGB Indian Grave Branch

IL L Lake

LTRC Lower Three Runs Creek

PB Poad B

PC Pond C

PEN Pen Branch

PP Par Pond

SC Steel Creok

TB Tims Branch

UTRC Upper Three Runs Creek

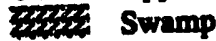

Figure 4-24. Concentrations of ${ }^{22} \mathrm{~T}$ (PCi/g) in Sediments from SRS Streams and the Savannah River Swamp in the Mid 1980s 
301 Bridge and Shell Bluff. The latter is a background bocation approximately $8 \mathrm{~km}$ upriver from Upper Three Runs Croek. The net concentration of $0.2 \mathrm{pCi} / \mathrm{h}$ in 1966 is based on downriver and upriver annual avenge concentrations of 0.3 and $0.1 \mathrm{pCi} / \mathrm{h}$, reapectively. In all other years, the upriver concentrations bave been either greater than the downriver values or loses than detection limita. In the latter case, no subtraction is performed; the dowruiver concentration is considered to be the net concentration.

The source of the ${ }^{211}$ in the Savannah River was direct discharges of diseseembly besin water from resctors to site streame. The maximum annual average concentration of 10 PCi/L occurred in 1960; another peak oceurred in 1962 at $8.5 \mathrm{pCi}$. Concentrations of ${ }^{211}$ in 1960-1963 are greater than the 1977 EPA drinking water standard of $3 \mathrm{PCi} / \mathrm{L}$ (EPA, 1977d).

The greateat concentration of ${ }^{131}$ in an individual sample of river water is aseociated with the 1957 fuel element failure in P Resctor. Just below the confluence of Steel Creek with the Savannah River the maximum concentration was 3,800 $\mathrm{PCi} / \mathrm{L}$. Further dowariver at Highway 301 Bridge, the maximum was $800 \mathrm{pCi} / \mathrm{L}$. The decrease in concentration reflects dilution of Steel Creek water by the Savamnah River.

The net concentrations are compared in Figure 4-25 to calculated downriver concentrations. The latter are determined by dividing annual total curies of ${ }^{211}$ I released to SRS treams that feed the Savannah River by the water volume transported in the Savannah River past SRS for aach individual year. Decay during the transit time to Highwny 301 is not considered. Releases of ${ }^{11}$ I from R-Reactor are also not considered; these were discharged to Par Pond. Except for 1960, measured and calculated results compare favorably.

Savannab River water has been intermittently analyzed for 129I between 1970 and 1981. Grab amples of water were collected downriver from SRS at Highway 301 Bridge and upriver from SRS at Shell Bluff (Andereon, 1978; Anderson, 1980; Kanielo, 1987). Concentrations of 1201 at both locations are shown in Figure 4-26. SRS is the principal source of ${ }^{129}$ in the river. Figure 426 shows that the downriver concentration typically excoeds the upriver concentration by an onder of magnitude. Downriver concentrations are typically less than 1 percent of the EPA drinking water atandard of 1pCi/L (EPA, 1977d).

Detection limits for individual samples are in the range of 0.0001 to $0.001 \mathrm{pCi} / \mathrm{L}$. The value of the detoction limit for a given ample is governed by a number of factors, such as volume sumpled and measurement interferences. The North
American river water background is on the order of $10^{-5}$ PCi/L (Braver, 1974).

The cocasional cetoction of ${ }^{22} \mathrm{I}$ in upriver water reflects the surface water transport of 120 from the watershed. Rainwater runoff in the waterahed transports ${ }^{22} I$ that is deposited from SRS atmospheric releases and global fallout. Aromalous results were obtained in the summer of 1978 when elevated concentrations of ${ }^{2 m}$ were detected in the upriver samples. As a result, concentrations upriver are ementially equal to corresponding concentrations downiver. The origin of this anomaly is unknown.

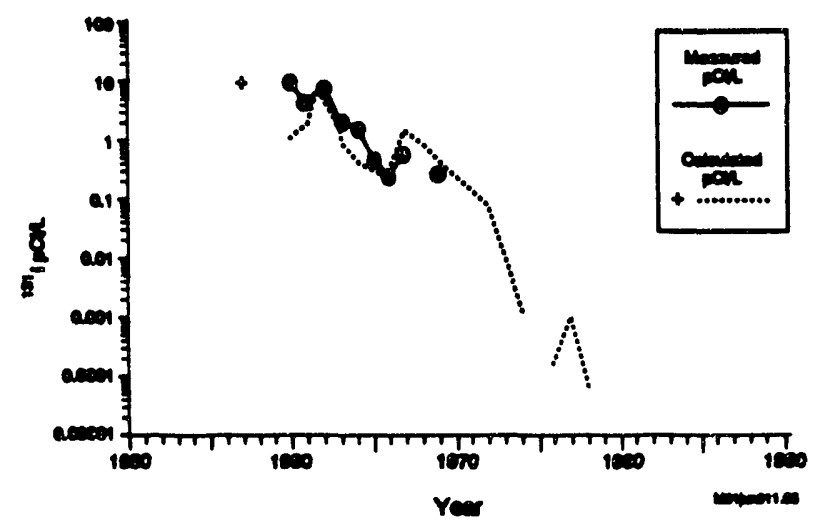

Fugure 425. Measured and Calculated River Concentrations of ${ }^{131}$ I due to SRS operations from 1957 through 1989 (Savannah River at Highway 301 Bridge Downriver from SRS)

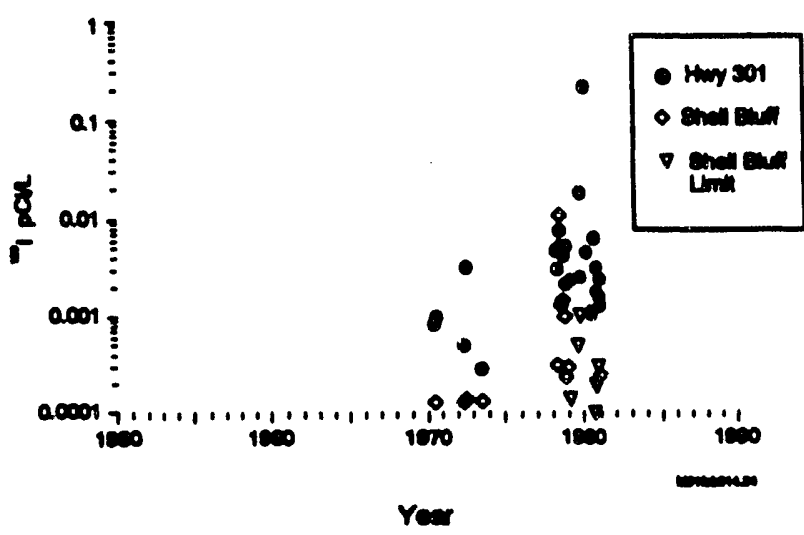

Droure 426. Comparison of ${ }^{221}$ Concentrations in the Savannah River Upriver and Downriver from SRS Measured Intermittently from 1970-1981 
The transport rate for SRS 121 in the Savanath River was initivlly eatimnted to be between 0.016 and 0.027 curies per year (Anderson, 1978; Andenson, 1980). When later messurements were aleo considered, the transport rate was determined to be 0.022 curies per year. This value continues to be used in annual environmental reports and release reports as the estimate for ${ }^{201}$ migration from the separations area seepage besins since 1980 . For this purpose the 0.022 curies is equally divided between the $F$ - and H-Area soepage basin systems. Migration from the seepage basins prior to 1980 is not coneidered. Figure $4-26$ shows that ${ }^{121}$ was detected in the Savannah River in 1970, although at lower concentrations than in the late 1970. Migration from the separations area scepage basins is the moat likely source of the 1970.

\section{Downriver Water Treatment Plants}

The Beaufort-Jasper Water Treatment Plant supplies water to Beaufort and Jasper counties in South Carolina. Operation of the plant, which has a capacity of $\mathbf{3 8}$ million liters per day, began in 1965 . Savannah River water is withdrawn near river-kilometer 65 and transported in a 29-km canal to the plunt.

The Port Wentworth Water Treatment Plant supplies vater to parts of Chatham County Georgia. The plant, which has a capacity of 170 million liters per day, was operating before SRS existed. Savannah River water is withdrawn from Abercorn Creek at a point about $3 \mathrm{~km}$ from its confluence with the Savannah River and transported through an 11-km pipeline to the plant. The mouth of Abercom Creek is near river-kilometer 46.

Although $12 \%$ at the water treatment plants has not been analyzed, concentrations are expected to be about $20 \%$ smaller than those at Highway 301. These are well below the EPA drinking water standard of $1 \mathrm{pCi} / \mathrm{L}$ for ${ }^{12 \%} \mathrm{I}$.

\section{Savannah River Estuary and Atlantic Coastal Waters}

No atudies of radioiodine in the estuary or coastal waters have been performed. 


\section{Summary of Aqueous Transport}

Migration of ${ }^{121}$ cocurs from the separations area scopage basins and the SWDF; the extent of ${ }^{21} 1$ migration from SWDF is not well defined. Groundwater ${ }^{22}$ I migrating from the separations area soepage besins began rewurfacing adjecent to Four Mile Croek probably as early a 1970. This is consistent with expected migration rates.

Groundwater concentrations of ${ }^{12 \%}$, which near the F-Area seepage beain syatem resch hundrods of $\mathrm{PCi} / \mathrm{h}$, are aseociated with tritium concentrations that are a fector of $10^{5}$ to $10^{\circ}$ greater. This relationship is used as an indicator for the presence or abeence of ${ }^{2} 1$ in other water. For exemple, groundwater from the Santee Formation is a minor source of drinking water for the $B$ and SRL areas at SRS. The lack of elevated tritium concentrations in this drinking water indicates that the portion of the formation tapped for drinking water is not contaminated with the 121 that contaminates the McBean Member of the Santee Formation near the R-Ares scepage besins. The source of the drinking water is not likely to become contaminated. The contaminated groundwater flows in the oppoaite direction, and Upper Three Runs Creek cuts through the Santee Formation to phyaically isolate F Area from the source of the drinking water.

Groundwater in the deeper Congaree Formation is also a minor source of drinking water at SRS. No 1201 bas been detected in groundwater from the Congaree Formation neas the separations area seepage basins. The atill doeper groundwater in the Black Croek-Middendorf formations (Tuecaloona aquifer) is the major source of drinking water at SRS.

The shallower groundwater principally resurfaces along seeplines adjecent to Four Mile Creek. Consequently, Four Mile Creek water contains the greatest ${ }^{22}$ I concentrations of site atreams.

Drainage of the atreams into the Savannah River is the principal source of ${ }^{2}$ I transported by the river. The large volume of river flow dilutes the elevated atream concentretions to levels typically leas than 1 percent of the EPA drinking water atandard.

Direct discharges of diseseembly basin water from resctors to site streams resultod in elevated concentrations of ${ }^{131} I$ in the Savannah River that during 1960-1963 exceed the 1977 EPA drinking water standard. No ${ }^{131}$ I has been detected stter 1968. 
Concesatrations of redioiodine st the downriver water treatment plants are expected to be similar to the concentre- tions measured in the Savannah River approximately $37 \mathrm{~km}$ downriver from SRS.

\section{Concentrations in Animals}

Atmoepheric and squeous transport of radiojodine results in the intake of redioiodine by wildife. This principally occuns by animals consuming vegetation and water that contains radiojodine from SRS releases and global fallout. Ingestod iodine is principally found in the thyroid gland of animals. Thyrcids were one of the firet types of environmental samples specifically analyzed for nadiojodine by SRS. Routine measurements of ${ }^{131}$ began in 1954 and routine measurements of ${ }^{121}$ began in 1984. Because animul thyroids are generally not eaten by humans, the dose to humans from this pathway is minimal.

Thymids from a variety of animals, both small and large, have been anulyzed. Table $4-6$ contains a summary of measurement reaults for those years when radioiodine was detected. Small animals include rabbit, for, recoon, bobcat, oposesum, squirrel, rat, owh, and quail. Large animals consiat of doer and cattle. Ercept for cattle, all of theac animals are collectod onsite; cattle are collectod from local offsite farms or slaughter bouses.

The muximum concentrations cocurred in 1956 and 1957 whea releases of ${ }^{231}$ I from the separations areas to both the atmosphere and coepage basins were at a maximum. A rat collected near the H-Area seepage basin in 1956 contained the greateat observed ${ }^{131}$ I thyroid concentration-7.1 $\times 10^{5}$ pCi/g. Other animals collected farther from the seepage basins in 1956 and 1957 had ${ }^{131}$ I thyroid concentrations of about 2,000 pCi/g. For compariton, global fallout in Tennessee during 1957 resulted in ${ }^{191}$ concentrations of 26,000 and $67,000 \mathrm{PCi} / \mathrm{g}$ in cattle and sheep thyroich, respectively, (Van Middlesworth, 1988).

In years other than 1956 and 1957, ${ }^{211}$ thyroid concentretions in animals never exceeded $1,000 \mathrm{pCi} / \mathrm{g}$. In many of those years, global fallout was a significant contributor of 131 I in thyroids. In 1954, 1955, 1958, 1961, and 1962 thyroids were collected coincident with the arrival of fallout from atmospheric nuclear weapons tast by the USSR or the USA. In 1966, 1967, and 1968 cattle thyroids were collestad specifically for research purposes soon after the arrival of fallout from Chinese teats.

The 1970 results represent two sepsante samplings of deer thyroids. The first set was collected in February to study the effects of atmospheric releases of ${ }^{131}$ I from $H$ Area. About 10 curies of ${ }^{111}$ I were released during the first eight weeks of 1970, due to the reprocessing of short-cooled neptunium targets. Eight thyroids were analyzed and found to have an average ${ }^{131}$ I concentration of $21 \mathrm{pCi} / \mathrm{g}$. The second 1970 sampling cocurred 2000 after the arrival of fallout from :
Chinese test in October. The avernge ${ }^{131}$ I concentration in thisty nine thyroids was $32 \mathrm{pCi} / \mathrm{g}$. The elevated results for 1976, 1977 , and 1980 are aleo attributed to fallout from Chinese teats.

The PHS opented a nationwide network, known as the Bovine Thyroid Network, from late 1964 to early 1969. The purpose was to analyze for ${ }^{131}$ I in bovine thyroids from regions of the country mear nuclear facilities. Network recults can be compared to the SRS results for cattle thyroids in 1966-1968.

Only the network reeults for thyroids collected at leat 100 kilometers from SRS in the southeastern states are considard for the comparison. These provide the southeastern background and are taken from references PHS, 1967e; PHS, 1968c; and PHS, 1969c. Network maximum ${ }^{131}$ concentrations are consiatent with the local maximum values in 1966 and 1968. The network maximum concentration in 1966 wes $702 \mathrm{pCi} / \mathrm{g}$ compared to the local maximum of $785 \mathrm{pCi} / \mathrm{g}$. The network thyroid was collected in Gwinett County, GA, approximately $230 \mathrm{kw}$ northwed of SRS. In 1968 the network and local maximun concentrations were 45 and $41 \mathrm{pCi} / \mathrm{g}$, respectively. The sthork thyroid was from Foreyth County, GA, approximatis $260 \mathrm{~km}$ northweat of SRS. In 1967 the network maxizzt: was 1,856 pCi/g, which excoeds the local maximum of $25 x$ pCi/g by a factor of six. The network thyroid was collesend in Tennescee in early January shortly after the arrival of fallout from the Chinese teat of December 28, 1966.

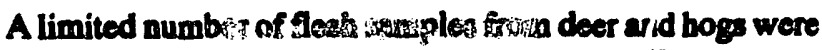

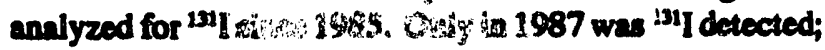
its concentration EN

Thyroid concentracios of hasta lived ${ }^{22}$ I are generally not affected by passing activity of ${ }^{20 I}$ produced in atmospheric nuclear weapons 
texts is arceedingly emall relative to the setivity of ${ }^{131}$ I (see Chpier 1).

Some of the thyroids from the Bovine Thyroid Network were included in a comprebensive nationwide aurvey for ${ }^{129}$ during 1964 to 1969 (Braver ot al., 1974). The average ${ }^{129}$ concentration in bovine thyroids from South Carolina and Georgin is $0.2 \mathrm{pCi} / \mathrm{g}$. Similar recults are observed in eastem Washington and northeastern Oregon near the Hanford nuclear fuel reproceasing facility. Concentrations are at least an order of magnitude lower in states that are more distant from SRS and Hanford.

In 1974, SRL conducted a preliminary unpubliahed tudy of 12 concentration in deer thyroids from the SRS site. The average thyroid concentration was $16 \mathrm{pCi} / \mathrm{g}$. Reaults of deer thyroid measurements conducted in later year generally proved to be consintent with this value. Routine measurements of doer thyroids from SRS begnn in 1984. Until 1989, the annual avernge concentrations nover exceeded the 1974 value of $16 \mathrm{pCi} / \mathrm{g}$. In 1989, the avernge 129 concentration rose to $63 \mathrm{pCi} / \mathrm{g}$. This is due to one deer thyroid with a concentration of $2,145 \mathrm{pCi} / \mathrm{g}$. The average concentration for 1989 without this thyroid is $11 \mathrm{pCi} / \mathrm{g}$, which is convistent with previous years.

The deer with the 2,145 $\mathrm{pCi} / \mathrm{s}$ concentration had likely ingented the 129 by consuming water and vegetntion from the seepline for the separations area seepage basins. The value of $2,145 \mathrm{pCi} / \mathrm{g}$ is similar to the maximum concentration of 3,700 pCi/g reported the Weat Valley nuclenr fuel reproceasing plant in New Yorts (Matuseck et al., 1974).

Tabie 46. Redioiodine in animal thyroids

\begin{tabular}{|c|c|c|c|c|c|c|}
\hline \multirow[b]{3}{*}{ Year } & \multicolumn{2}{|c|}{ Animal } & \multicolumn{4}{|c|}{ Detected Comcentratton pCV/c } \\
\hline & \multirow{2}{*}{$\begin{array}{l}\text { Namber } \\
\text { Analyzed }\end{array}$} & \multirow[b]{2}{*}{ Type } & \multicolumn{2}{|c|}{ मा } & \multicolumn{2}{|c|}{1} \\
\hline & & & Average & Madinnen & Average & Mnxtmun \\
\hline 1954 & 3 & anall & 103 & 142 & & \\
\hline 1955 & 27 & small & 33 & 96 & & \\
\hline 1956 & 60 & $\operatorname{sinall}$ & $*$ & $7.1 \times 10^{5}$ & & \\
\hline 1957 & $\bullet$ & $*$ & $*$ & $2.8 \times 10^{5}$ & & \\
\hline 1958 & 32 & $\cdots$ & $*$ & 680 & & \\
\hline 1961 & 3 & doer & 135 & 190 & & \\
\hline & 34 & anall & 120 & 655 & & \\
\hline & 3 & $\infty$ & $*$ & 250 & & \\
\hline 1962 & 7 & doer + small & 50 & $*$ & & \\
\hline 1966 & $\bullet$ & cattle & $\cdots$ & 785 & & \\
\hline 1967 & $\cdots$ & cattle & $*$ & 290 & & \\
\hline 1968 & $*$ & cattle & $*$ & 41 & & \\
\hline 1970 & 47 & deer & 30 & 93 & & \\
\hline 1974 & 12 & doer & & & 16 & 91 \\
\hline 1976 & 65 & deer & 150 & 670 & & \\
\hline 1977 & 70 & doer & $*$ & 410 & & \\
\hline 1980 & 48 & doer & 6 & 9 & & \\
\hline 1984 & 58 & doer & & & 15 & 210 \\
\hline 1985 & 22 & doer & & & 4 & 31 \\
\hline 1986 & 38 & deer & & & 2 & 5 \\
\hline 1987 & 24 & doer & & & 3 & 16 \\
\hline 1988 & 24 & doer & & & 3 & 20 \\
\hline 1989 & 41 & deer & & & 63 & 2,145 \\
\hline
\end{tabular}

- Concentration units are pCi per gram wet weight.

- Unspecified in published report. 


\section{References for Chapter 4}

Andland, R. K. and H. W. Bledece, "Classification of Hydrostatigraphic Units at the Savannah River Site, South Carolin", WSRC-RP-90-987, Westinghouse Savannah River Company, Aikea, SC.

Anderson, T. J., 1978, "Iodine-129 in the Bnvironment of a Nuclear Fuel Reprocessing Plant by Neutron Activation Analysis", DP-MS-78-51, E. I. du Pont de Nemours and Company, Aiken, SC.

Anderson, TJ, 1980, "Methodology for the Determination of Environmental "1 and "Tc", in: "Effluent and Environmental Radiation Surveillance, ASTM STP 698", J. J. Kelly, Ed. American Socicty Teating Materials, Philadelphia, p. 84.

Bennett, B. G., 1978, "Environmental Aspects of Americium", EML-348, US Department of Energy, New York.

Boone, F.W., M.V. Kantelo, P.G. Mayer, and J.M. Palms, 1985, "Residence Half-Times of ${ }^{12} 1$ in Undisturbed Surfece Soils Based on Measured Soil Concentration Profiles", Health Physics 48, 401.

Bruer, F. P., 1974, "Environmental 129 Measurements", BNWL-SA-4983, Battelle Pacific Northwest Laboratory, Richland, WA.

Brauer, F.P., J.K. Soldat, H. Tenny, and R.S. Strebin, Jr., 1974, "Natural lodine and lodino-129 in Mammalian Thyroids and Environmental Samples Taken from Sites in the USA", (IAEA-SM-180/34), in: "Environmental Surveillance Around Nuclear Installations", Vol II, International Atomic Energy Agency, Vienna, p. 43.

Braver, F.P. and R.S. Strebin, Jr, 1982, "Environmental Concentration and Migration of ${ }^{120} \mathrm{~T}$, (IAEASM-257/43), in: "Environmental Migntion of LongLived Radionuclides", IAEA STUPUB/597, International Atomic Energy Agency, Vienne, p. 465.

Bruner, H. D., 1963, "Symposium on the Biology of Radioiodine: Statement of the Problem", Health Physics 9, 1083.

Campbell, J. E and G. K. Murthy, 1963, "Summary of Results from the Raw Mill Sampling Program", Radiological Health Data 4, 511.
Carter, M. W. and A. A. Moghisxi, 1977, "Three Decades of Nuclear Testing", Health Physics 33, 55.

Codell, R.B and J.D. Duguid, 1983, Transport of Redionuclides in Groundwater", in "Radiological A. sessment", J.E. Till and H.R. Meyer, Eds., NUREG/ CR-3332, U.S. Nuclen Regulatory Commission, Washington, D.C, p.4-1.

Corbo, P., M.V. Kantelo, and C.B. Fliermans, 1985, “Amalytical Results, Database Management and Quality Assurance for Analysis of Soil Cores from the F- and H-Area Seepage Busins", DPST-85-921, E.I. du Pont de Nemours and Company, Aiken, SC.

EMS, 1989a, The Savannah River Site's Groundwater Monitoring Program, Second Qunter 1989", BSHEMS-890044, Westinghouse Savannah River Company, Aiken, SC, p. 264.

EMS, 1989b, The Savannah River Site's Groundwater Monitoring Program, Third Quarter 1989", ESHEMS-8900445, Weetinghouse Savannh River Compony, Aiken, SC, p. 12.

EPA, 1971a, Radiological Health Data and Reports 12, pp. 108,153 , and 212.

EPA, 1971b, Radiological Health Data and Reports 12, 199.

EPA, 1972a, Rediological Data and Reports (formerly Radiological Health Data and Reports) 13, pp. 282, 368, $407,443,514,566,637$, and 698 .

EPA, 1972b, Radiological Data and Reports 13, Pp. 255, $347,393,425,479,547,619$, and 659 .

EPA, 19732, Radiological Data and Reports 14, pp. 36, 116, 203, and 257.

EPA, 1973b, Radiological Data and Reports 14, pp. 17, 85, 175 , and 237.

EPA, 1976, Environmental Radiation Dath, Reports 5 and 6, US Environmental Protection Agency, Montgomery, A.

EPA, 19774, Environmental Radiation Data, Reports 7, 8, 9, 10, and 11, US Environmental Protection Agency, Montgomery, AL. 
EPA, 19776, Environmental Radiation Dats, Report 8, US Bnvironmental Protection Agency, Montgomery, AL.

EPA, 1977c, Environmental Rediation Date, Reports 7 and 11, US Envionmental Protection Agency, Montgomery, AL.

EPA, 1977d, National Interim Primary Drinking Water Regulation", BPA-5709-76-003, US Environmental Protection Agency, Washington, DC, pp. 155 and 156.

EPA, 1978, Environmental Radiation Data, Report 12, US Environmental Protection Agency, Montgomery, AL.

EPA, 1978b, Environmental Radiation Dats, Reports 13 and 14, US Environmental Protection Agency, Montgomery, Al.

EPA, 1979a, Environmental Rediation Date, Reports 15 and 16. US Environmental Protection Agency, Montgomery, Al.

EPA, 1979b, Environmental Radiation Date, Report 17, US Environmental Protection Agency, Montgomery, AL.

EPA, 1981, Environmental Radiation Data, Report 25-26, US Environmental Agency, Montgomery, AL.

EPA, 1986n, Environmental Radiation Date, Report 46, EPA-520/5-87-004, US Environmental Protection Agency, Montgomery, AL.

EPA, 1986b, Environmental Radiation Dath, Reports 44-45, 46, 47, and 48, US Environmental Agency, Montgomery, AL.

Haselow, J.S., M. Harris, B.B. Looney, N.V. Halveren, and J.B. Gladden, 1990, “Analysis of Soil and Water at the Four Mile Creek Seepline near the F\&H Arens of SRS", WSRC-RP-90-0591, Weatinghouse Savannah River Company, Aiken, SC.

Hewkins, R.W., 1983, "Mobility of ${ }^{129}$ in Buried Waste", DPST-83-590, E. I. du Pont de Nemours and Company, Aiken, SC.

Hochel, R.C., 1976, "Preliminary I-129 Mensurements in the SRP Environs", DPST-76-221, E. I. du Pont de Nemours and Company, Aiken, SC.

Hoeffner, S.L., 1985, “Radionuclide Sorption on Savannah River Plant Burial Ground Soil - A Summary and In- terpretation of Laboratory Data", DP-1702, E.I. du Pont de Nemours and Company, Aiken, SC.

Kantelo, M. V., B. Tiffiany, and T. J. Anderson, 1982, "Iodino-129 Distribution in the Terreatrial Environment

- Surrounding a Nuclear Fuel Reprocescing Plant after 25 Years of Operation", (IAEA-SM-257/53P), in: "Environmental Migration of Long-Lived Radionuclides", IAEA STIPUB/597, International Atomic Energy Agency, Vienna, p 495.

Kantelo, M.V. and W.G. Winn, 1986, "Summary of Chernobyl Fallout Monitoring by the Environmental Rediometrics Group", DPST-86-624, E. I. du Pont de Nemours and Company, Aiken, SC.

Kantelo, M.V., 1987, "Summary of I-129 Messurement in Ground and Surfece Waters", DPST-87-820, E. I. du Pont de Nemours and Company, Aiken, SC.

Little, P. and M. H. Martin, 1972, "A Survey of Zinc, Lead and Cadmium in Soil and Natural Vegetation Around - Smelting Complex", Environmental Poilution 3. 241.

Lower, M.W., 1987, "Comprebennive Cooling Water Study, Final Report, Volume II, Retionuclide and Heavy Metal Transport," DP-1739-3, E. I. du Pont de Nemours and Company, Aiken, SC.

Marter, W. L, 1963, "Radioiodine Relense Incident at the Savannah River Plant", Health Phyaics 9, 1105.

Marter, W.L., 1974, "Redionctivity from SRP Operations in a Downstream Savannah River Swamp", DP-1370, E. I. du Pont de Nemours and Compeny, Aiken, SC.

Matusek, J. M., J. C. Daly, S. Goodyear, C. J. Paperiello, and J. J. Gabay, 1974, "Environmental Levels of Iodine-129", (IAEA-SM-180/39), in: "Environmental Surveillance Around Nuclear Installations", Vol II, International Atomic Bnergy Agency, Vienna, p. 3.

Mclntyre, P. F. and E. L. Wilhite, 1988, "Radionuclide Analyses of Burial Ground Well Waters", DPST-88-375, E. I. du Pont de Neurours and Company, Aiken, S.C.

Muramateu, Y. and Y. Ohmomo, 1986, Todino-129 and lodine-127 in Environmental Samples Collected from Tokaimura/lbaraki, Japan", The Science of the Total Environment 48, 33. 
Murphy, C.E., Jr, L.R. Buver, D.W. Hayea, W.L. Marter, C.C. Zoigler, D.Z Stephenson, D.D. Hoel, and D.M. Hamby, 1990, Tritium in the Savannah River Site Environment", WSRC-RP-90-424-1, Weatinghouse Savannsh River Company, Aiken, SC.

Murphy, C. E., Jr., 19912, “Jodine Deposition in the Vicinity of SRS", SRLESS-91-713, Weatinghouse Savannah River Company, Aiken, SC.

Murphy, C. E, Jr., 1991b, "Estimnting Deposition Velocity from Atmospheric Relesses of lodine", WSRCTR-91-72, Westinghouse Savannah River Company, Aiken, SC.

NCRP, 1984, "Radiologied Assessment: Predicting the Transport, Biosccumulation, and Uptake by Man of Radionuclides Relessed to the Environment", Report No. 76, National Council on Radiation Protection and Messurements, Bethesda, MD.

Oblath, S.B, 1986, "Technetium-99 and Iodine-129 in the Burial Ground Plume", DPST-86-278, E. I. du Pont de Nemours and Company, Aiken, SC.

Perkins, R. W. and C. W. Thomas, 1980, “Worldwide Fallout", p. 55, in: "Transuranic Elements in the Environment", DOE/TIC-22800, US Department of Energy, Washington, DC.

PHS, 1960, Radiological Health Data 1(4), 33.

PHS, 1960b, Radiological Health Data 1(8), 17.

PHS, 1961, Radiological Health Data 2, Pp. 9, 175, 298, and 434.

PHS, 1962, “Air Pollution Measurements of the National Air Sampling Network", Publication No. 978, Public Health Service, Washington, DC.

PHS, 1962b, Radiological Health Data 3, pp. 7, 111, 220, and 385.

PHS, 1962c, Radiologicai Health Data 3, pp. 246, 336, and 397.

PHS, 1962d, "Factors Influencing Strontium-90 in Milk from the Brainerd, Minn. Milkshed", Publication No. 999-R-1, Public Heaith Service, Washington, DC.

PHS, 1963a, Radiological Health Data 4,167.
PHS, 1963b, Radiological Health Data 4, pp. 3, 167, 335, and 487.

PHS, 1963c, Radiological Health Data 4, pp. 138, and 291.

PHS, 1964a, Radiological Health Data 5, 155.

PHS, 1964b, Radiological Health Date 5, pp. 5, 155, 305, $457,461,521$, and 579.

PHS, 1964c, Radiological Health Data 5, 179.

PHS, 1965, Radiological Health Data 6, 181.

PHS, 1965b, Radiological Health Data 6, pp. 1, 77, 123, 177, $241,291,333,411,469,525,597$, and 667 .

PHS, 1965c, Radiological Health Data 6, 209.

PHS, 1966a, Radiological Health Date and Reports (formerly Radiological Health Data) 7, 239.

PHS, 19666, Radiological Health Dace and Reports 7, pp. $33,106,182,233,302,364,410,466,590,658$, and 720.

PHS, 1966c, Radiological Health Data and Reports 7, pp. 446, 562, and 567.

PHS, 1967a, Radiological Health Data and Reports 8, 224.

PHS, 1967b, Radiological Health Data and Reports 8, pp. $29,102,162,217,282,340,396,458,525,606,656$, and 722.

PHS, 1967c, Radiological Health Data and Reports 8, Pp. 6 and 196.

PHS, 1967d, Radiological Health Data and Reports 8, 252.

PHS, 1967e, Radiological Health Date and Reports 8, pp. 51,227 , and 465 .

PHS, 1968a, Radiological Health Data and Reports 9, pp. $46,113,173,226,273,313,372,450,505,571,674$, and 757.

PHS, 1968b, Rediological Health Data and Reports 9, 204.

PHS, 1968c, Radiological Health Data and Reports 9, pp. $120,280,456$, and 695 . 
PHS, 1969e, Radiological Health Data and Reports 10, pp. $30,71,120,163,217,266,317,364,400,456,516$, and 570 .

PHS, 1969b, Radiological Health Data and Reports 10, 139.

PHS, 1969c, Radiological Health Data and Reports 10, pp. 77 and 178.

PHS, 1970a, Radiological Health Data and Reports 11, pp. 254, 306, 350, 404, 468, 546, 642, and 696.

PHS, 19706, Radiological Health Data and Reports 11, Pp. $30,86,158$, and 200.

PHS, 197 , Radiological Health Data and Reports 11, 187.

PHS, 1971, Radiological Health Data and Reports 12, pp. 47 and 153.

Rickard, W. H., D. G. Wateon, B. Klepper, J. F. Cline, F. P. Brawer, and J. E. Fager, 1974, "Iodino-129 in Soil and Vegetation in the Environs of Nuclear Fuels Reproccasing Plants", BNWL-1850 PT2, Battelle Pacific Northweat Laboratory, Richland, WA, p. 44.

Robens, E., J. Hauschild, and D. C. Auman, 1989, "Iodino-129 in the Environment of a Nuclear Fuel Reprocessing Plant: IV. ${ }^{129}$ and ${ }^{22}$ I in Undisturbed Surface Soils", Journal of Environmental Radionctivi" 9, 17.

Robinson, P. B., 1968, “A Comparison of Results Between the Public Health Service Raw Millk and Pasteurized Milk Networks for January 1964 Through June 1966", Radiological Health Data and Reports 9, 475.
Schuttelkopf, H. and M. Pimph, 1982, "Radioecological Studies on Plutonium and lodino-139 in the Surroundings of the Karlerube Reprocosaing Plant", (IAEA-SM-257/100) in: "Environmental Migration of Long-Livod Radionuclides", LAEA STIPUB/597, International Atomic Energy Agency, Vienne, p. 395.

Shedrow, C.B., 1986, "A Charecterization Study of the Old F-Area Seepage Basin at the United States Department of Energy's Savanmeh River Plant", C.B. Shedrow Environmental Consultants, Inc., Report No. CORR-87-0117, Columbia, SC.

Sigs, R. A., 1986, "TRAC Laboratory Monitoring of Chernobyl Rudionctive Debris", DPST-86-483, E. I. du Pont de Nemours and Company, Aiken, SC.

Sige, R. A., 1989, "Monitoring Chernobyl Fallout in Population Centers near Savannah River Site", Transactions of the American Nuclear Society 60, 73.

Stewart, S. P. and B. T. Wilkins, 1985, "Areal diatribution of 121 in Weat Cumbrian Soils", Journal of Environmental Radiosetivity 2, 175.

UNSCEAR, 1982, "lonizing Radiation: Sources and Biological Effects", United Nations Scientific Comrnittoe on the Effect of Atomic Radiation, New Yort, p. 227.

Van Middleoworth, L, 1988, "Cosium-137 and ${ }^{131}$ in Thyroids of Cattle and Sheep After Nuclear Accidents and Weapons Testen, Health Physics 55, 809.

Winn, W. G. and M. V. Kantelo, 1989, Time-Dependent Study of Chernobyl Fallout Near Savannah River Site", Transactions of the American Nuclear Society $60,75$. 


\section{5}

This chapier describes the health impacts associated with exposwere 10 radioiodine. The methodology used to produce dose estimates is presented. The results of the dase assessment for radioiodine releases from 1955 tol1989 are discussed.

Radiation doses are sometimes expressed in terms of rad (radiation absorbed dase). A dase of one rad is equal to the absorption of 100 ergs of energy per gram of absorbing material. Since one rad of absorbed dose from different types of radiation can have different biological effects in humans, the unit of rem was developed. Rem dases, or more precisely, dase equivalents, are obtained by multiplying rad doses by a quality factor. The quality factor places doses on a common scale of biological effect (carcinogenesis) for all types of ionizing radiation. The quality factor for $x$-rays, gamma rays, and beta particles is 1 (one). Thus, in the case of internal doses from $x$-rays, gamma rays, and beta particles, one rad is equal to one rem.

The rem is too large to conveniently represent doses from environmental radiation. The millirem (mrem), which is one one-thousandth of a rem, is used for this purpose. 


\section{Relationship of Dose to Risk and Health Effects}

Expoure of humans to radiation increases the risk of cancer, genetic changes, and fetal abnormalities. Risk factore adopted by the EPA are used to assess the impact of radioiodine releases from SRS.

\section{Ionizing Radiation}

Ionixing radiation is radiation that strips the electrons from the matter through which it pasees. The interection of ionizing ratintion with biological systems can induce a series of chemical reactions that can cause permanent changes in the genetic material of cells. These changes (mutatious) may cause abnormal functioning within the cell or may lead to cell death.

The nature of radiation-induced cellular changes is dependent upon the magnitude of the dose and the rate at which it is received. For the low doses and dose rates encountered in the environment from SRS relenses, the most significant type of effect is cancer induction.

This is believed to be a stochastic effect; in other words, an increase in dose increases the probability of the effect, but the severity of the effect is independent of the dose. An illustration of this approach to the dose-response relationship is provided in Figure 5-1.

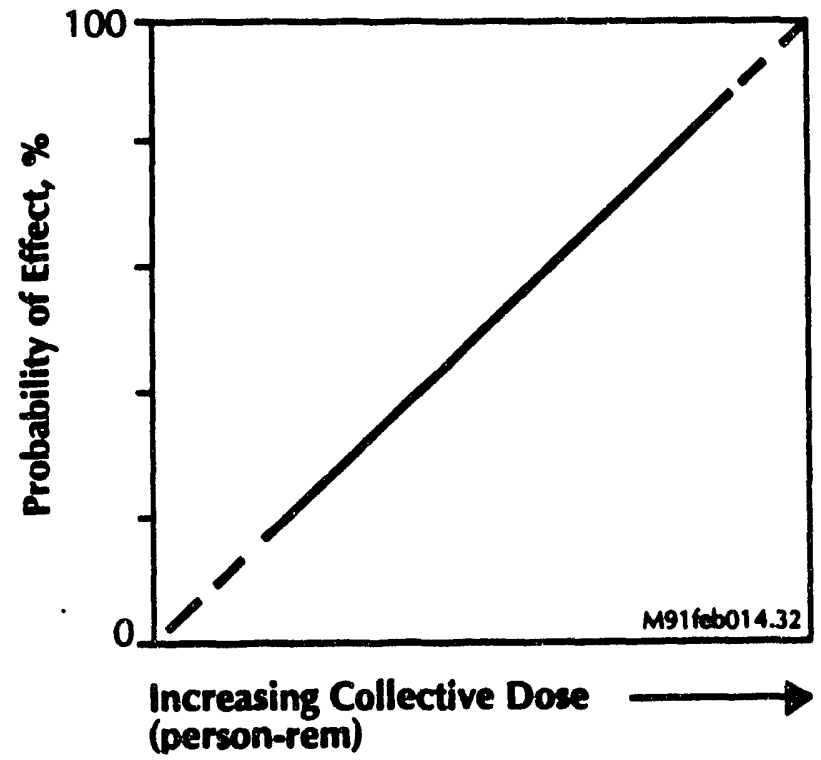

Figure 5-1
As seen in the figure, a charecteristic of stochastic risk is the absence of a threshold. In other words, it is conceivable that any dose of radiation, no matter how small, might give rise to a cancer. On the other hand, there is no way to be certain that a given doee, no matter bow large, has caused or ultimately will cause a cancer in an individual.

\section{Cancer Risk Estimates}

The most comprehensive estimates of cancer induction by exposure to ionizing rediation come from studies of the atomic bomb survivors at Hiroehima and Nagasak. Leas definitive studies include those of medical patients exposed to therapeutic and diagnostic radiation. Studies of laboretory animals have increased the understanding of doso-effect relationships. The International Commission on Radiological Protection (ICRP) has evaluated all of these studies and concluded that the beat eatimate of lifetime risk of fatal cancer for members of the general population is approximately 500 cases per 1,000,000 pernon-rem (ICRP, 1991). This is equivalent to one case per 2000 person-rem. 


\title{
Radioiodine Exposure and Dose to Humans
}

\begin{abstract}
Stablo iodine is an easential trece constituent in the human body. The adult body contains an average of 0.011 grams; in a typical adult, approximately 0.010 of the 0.011 grams are in the thyroid gland. The thyroid, an endocrine gland in the throat below the larynx, secretes iodine-bearing hormones, which are ceential for maintaining normal metabolism in all body celle.
\end{abstract}

Redionctive isotopes of iodine have the anme biochemical behuvior in the human body as stable iodine, i.e., a large fraction of intake is found in the thyroid gland. Radioiodine released to the environment from the nuclear industry and from weapons teats can exiat in a variety of organic and inorganic forms. Humans are exposed to redioiodine in the environment by inbalation and by ingeation of food and water.

\section{Distribution and Retention of lodine in the Human Body}

Eacentially all of the iodine that enters the lungs and the gestrointeatinal trect is aceumed to be repidly abeorbed in body fluids (ICRP, 1979; ICRP 1989). This sesumption is based on experiments with mice, rate, dops and sheep (Willurd and Bair, 1961; Bair et al., 1963). In all age groupa of bumans, with the exception of newborn infants up to 5 days, the fraction transferred to the thyroid is 0.3 . Fractional uptake by the thyroid gland of newborns is about 0.7 , declining to values at or below that obeerved for adults by five days after birth (ICRP, 1989). Iodine that does not reach the thyroid is aseumed to 80 directly to excretion (ICRP, 1979).

The thyroid secretes organic iodine in the form of hormones into the blood. The iodine is metabolized in tiscues and returned to the plasme pool as inorgnnic iodide; therefore, some iodine will be recycled to the thyroid. About 20 percent of the crganic iodide is excreted in the feces. Mot of the inorganic iodine is excreted in the urine (ICRP, 1989).

The turnover rate (rate of depletion) of natural iodine in the thyroid gland and the reat of the body decreases with increasing age as shown in Table 5-2. These biokinetic dath are used in the ICRP model (ICRP, 1989) to calculate age-dependent internal doses from radioiodine. Also shown in Table 5-2 are standardized maseses of the thyroid and body for various age groups.

\section{Radiation Carcinogenesis of the Thyroid Gland (BEIR, 1990)}

The poacible radiological darnage to the thyroid gland fiom burnan exposure to radioiodine can manifeat itwelf in the ivim of immediate phyrical damage (cell death from very high dones) or an increased incidence of cancer. Dowes high enough to cause immodiate phyaical damage would norely be encountered except in the intentional administration of rediojodine by medical practitioners ior therapentic purposes. Of more concern are radiogenic thyroid abnormalities that might be asociated with unusual environmental exposure from inbalation and ingeation of food and water.

Table 5-2. Biokinetic data and atandard organ mases for radioiodine dose calculations

\begin{tabular}{|c|c|c|c|c|c|c|}
\hline \multirow[b]{2}{*}{ Age } & \multirow{2}{*}{$\begin{array}{l}\text { Druetional } \\
\text { Uptake by } \\
\text { Thyrold }\end{array}$} & \multicolumn{2}{|c|}{$\begin{array}{l}\text { Blological } \\
\text { Bilf-time, dass }\end{array}$} & \multirow{2}{*}{$\frac{\text { Bafpeareat }}{\text { Thyrod }}$} & \multicolumn{2}{|c|}{ Standard Mans, 8} \\
\hline & & Thyrold & Body & & Thyrod & Body \\
\hline $3 \mathrm{mos}$ & 0.3 & 112 & 1.12 & 15 & 1.29 & 6,000 \\
\hline $1 \mathbf{y r}$ & 0.3 & 15.0 & 1.50 & 20 & 1.78 & 9,800 \\
\hline 5 yrs & 0.3 & 23.0 & 2.30 & 30 & 3.45 & 19,000 \\
\hline $10 \mathrm{ym}$ & 0.3 & 58.0 & 5.80 & 70 & 7.93 & 32,000 \\
\hline $15 \mathrm{ym}$ & 0.3 & 67.0 & 6.70 & 80 & 12.40 & 55,000 \\
\hline Adult & 0.3 & 80.0 & 12.00 & 91 & 20.00 & 70,000 \\
\hline
\end{tabular}


An increaned incidence of thyroid cancer from ionizing radiation hes been obearved in a number of groups including infants expoeed to therepeutic $x$-rnyes Japaneece A-bomb survivore, and Marahall Ielanders expoeed to rediosctive fillout from nuclear weapons teets. Studies of these groups indicase that the greateat ausceptibility to radiation-induced thyroid cancer occurs during infancy and early childhoodespecially during the firnt five years. In thoee individuals exposed before puberty, the tumors usually do not become apparent until after sexual maturation. The risk of rediation-induced cancer in adults is only one-half, or lese, of that in childrea. Fermales are roughly three times more sensitive than males to radiogenic thyroid cancer.

Diagnotic procedures to evaluate thyroid function commonly use 212I. In one large tudy of 35,000 people undergoing wach teets, the mean thyroid dowe was 50 rad. The reaults of the atudy auggeat that diagnoctic dowes of ${ }^{131}$ I do not significantly increase the risk of thyroid cancer.

Acoepted criteria for the definitions of various types of thyroid neoplasms have been developed and promulgated by the World Health Organization. This claseification system divides thyroid cancers into follicular, papillary, squamous cell, undifferentiated (anaplatic), and medullary typea. Medical tudiea have indicated that radiogenic thyroid cancers are generally papillary growths; relatively few are follicular or mixed pathology. Radiogenic thyroid cancer causes death in only about 10 percent of all cases. The more malignent types of thyroid cancers have not been found to have a radiogenic origin.

\section{lodine Dosimetry}

The inhalation and ingestion of all common compounds of radioiodine results in 100 percent transfer into the blood. Approximately 30 percent of the intake translocates to the thyroid, except in newborn infants. The ICRP (ICRP, 1989) has adopted a throe-compartment model to describe the biokinetics of iodine after entry into the blood. The compartments are (1) blood, (2) thyroid, and (3) rest of the body.

This model allows for recycling of radioiodine released from the thyroid in the form of organic iodine compounds (hormones). The consideration of recycling is only necessary for long-lived isotopes of iodine. Because iodine is recycled through the thyroid, monitoring the gland after an intake of radioiodine will not reveal a single exponential clearnoce, but would be approximately described by the sum of two exponentials

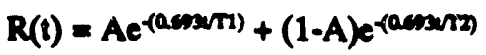

where

$R(t)=$ fractional retention in the thyroid gland as a function of time, $t$

$A=$ initial uptake by the thyroid gland

$T 1$ and $T 2=$ observed half-times for clearance

Retention data are largely determined using ${ }^{131}$ I whoce 8-day radiological half-life is too short to observe a two-exponential clearance. For donimetric purposes, a single mean apparent half-time of 91 days for atable iodine in adult has been adopted (ICRP 1989) to replece the two-exponential biological balf-timea. Values for other age groups are: 3 mort the - 15 daye, 1 year -20 days, 5 years -30 days, 10 years - 70 days, and 15 years - 80 days. These apparent half-times were used to calculate the biological half-times shown in Table 5-2. In previous ICRP internal dose calculations (ICRP, 1979), a biological half-time of 120 days was assumed for the adult thyroid.

The newer age-apecific internal dowe factors in ICRP 1989 represent dose commitments from the age of intake until age 70. Thus, the integrating period varies with each age group. However, all redioiodine inotopes are effectively eliminated from the body in periods ranging from a few days to a fow years after intake.

The iodine dose conversion factors used in the late 1980 by DOE were calculated with 1979 ICRP methodology. A comparison of those factors with the values calculated using 1989 ICRP methodology is shown in Table 5-3.

The ICRP 1989 internal doee factom for adults in Table 5-3 are lower than corresponding DOE 1988 dose factors. This difference is the reeult of the shorter biological half-life used in ICRP 1989. The differences are small for isotopes with short radiological half-lives ( ${ }^{311}$ and ${ }^{132}$ ), but more significant for the long-lived ${ }^{22 \%}$.

ICRP 1989 limited its consideration of age-dependent doce factors to the moat rediologically significant irotopes that might be released to the environment dus to various human activities. Thus, age-dependent ICRP 1989 dose factors were only provided for three radioinotopes of iodine: 221 , ${ }^{131} 1$, and ${ }^{13} 1$. The DOE doce factors include all iodine isotopes with radiological half-lives long enough to result in a significant internal dose; DOE dose fectors are limited to sdults. 
Table 5-3. Internal dose factors for iodine isotopes

\begin{tabular}{|c|c|c|c|c|c|c|c|c|}
\hline \multirow[b]{2}{*}{ Ieotope } & \multirow[b]{2}{*}{$\begin{array}{l}\text { Radio- } \\
\text { logical } \\
\text { Halle-life }\end{array}$} & \multirow[b]{2}{*}{$\begin{array}{l}\text { Are } \\
\text { Group }\end{array}$} & \multirow[b]{2}{*}{$\begin{array}{l}\text { Intake } \\
\text { Mode }\end{array}$} & \multicolumn{4}{|c|}{ Doee Factor, mrem/pCI } & \multirow[b]{2}{*}{ Reference } \\
\hline & & & & EDE* & $\begin{array}{l}\text { Stomseh } \\
\text { Wall }\end{array}$ & Thyrold & Lung & \\
\hline 125 & $60.14 d$ & $\begin{array}{l}\text { adulk } \\
\text { adult }\end{array}$ & $\begin{array}{l}\text { ingeation } \\
\text { inhalation }\end{array}$ & $\begin{array}{l}3.8 \times 10^{-05} \\
2.4 \times 10^{-08}\end{array}$ & - & $\begin{array}{l}1.3 \times 10^{-00} \\
8.1 \times 10^{-4}\end{array}$ & $\overline{-}$ & $\begin{array}{l}\text { DOE } 1988 \\
\text { DOE } 1988\end{array}$ \\
\hline$x_{I}$ & $13.02 \mathrm{~d}$ & $\begin{array}{l}\text { scult } \\
\text { sdult }\end{array}$ & $\begin{array}{l}\text { ingeation } \\
\text { inhalation }\end{array}$ & $\begin{array}{l}7.1 \times 10^{-00} \\
4.3 \times 10^{-00}\end{array}$ & $\overline{-}$ & $\begin{array}{l}2.4 \times 10^{-00} \\
1.4 \times 10^{00}\end{array}$ & $\overline{-}$ & $\begin{array}{l}\text { DOE } 1988 \\
\text { DOE } 1988\end{array}$ \\
\hline${ }^{2 m I}$ & $24.99 \mathrm{~m}$ & $\begin{array}{l}\text { adult } \\
\text { adult }\end{array}$ & $\begin{array}{l}\text { ingeation } \\
\text { inhalation }\end{array}$ & $\begin{array}{l}8.5 \times 10^{00} \\
4.5 \times 10^{-00}\end{array}$ & $\begin{array}{l}1.2 \times 10^{-0} \\
1.2 \times 10^{-07}\end{array}$ & $\begin{array}{l}4.1 \times 10^{-01} \\
2.0 \times 10^{-01}\end{array}$ & $\overline{2.7} \times 10^{-17}$ & $\begin{array}{l}\text { DOE } 1988 \\
\text { DOE } 1988\end{array}$ \\
\hline 1201 & $1.57 \times 10^{7} y$ & $\begin{array}{l}3 \mathrm{mos} \\
1 \mathrm{yr} \\
5 \mathrm{yrs} \\
10 \mathrm{yrs} \\
15 \mathrm{yrs} \\
\text { adult }\end{array}$ & $\begin{array}{l}\text { ingeation } \\
\text { inhalation } \\
\text { ingestion } \\
\text { inhalation } \\
\text { ingestion } \\
\text { inhalation } \\
\text { ingestion } \\
\text { inhalation } \\
\text { ingestion } \\
\text { inhalation } \\
\text { ingestion } \\
\text { ingestion } \\
\text { inhalation } \\
\text { inhalation }\end{array}$ & $\begin{array}{l}4.1 \times 10^{-4} \\
2.6 \times 10^{-4} \\
4.8 \times 10^{-4} \\
3.0 \times 10^{-4} \\
3.7 \times 10^{-4} \\
2.4 \times 10^{-4} \\
4.1 \times 10^{-4} \\
2.7 \times 10^{-4} \\
3.1 \times 10^{-4} \\
2.0 \times 10^{-4} \\
2.4 \times 10^{-4} \\
2.8 \times 10^{-4} \\
1.5 \times 10^{-4} \\
1.8 \times 10^{-4}\end{array}$ & $\begin{array}{l}4.4 \times 10^{-0} \\
1.1 \times 10^{-0} \\
2.6 \times 10^{-0} \\
6.7 \times 10^{-0} \\
1.4 \times 10^{-0} \\
4.1 \times 10^{-0} \\
1.0 \times 10^{-0} \\
3.7 \times 10^{-0} \\
7.0 \times 10^{-0} \\
2.6 \times 10^{-0} \\
7.4 \times 10^{-0} \\
- \\
3.1 \times 10^{-07} \\
-\end{array}$ & 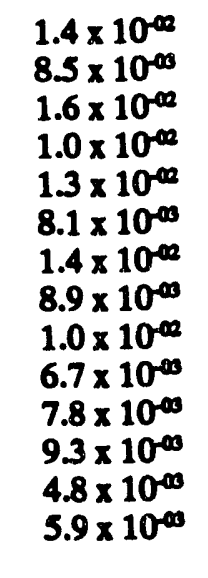 & $\begin{array}{l}\overline{8.1} \times 10^{-0} \\
\overline{1.3} \times 10^{-00} \\
\overline{7} .8 \times 10^{-07} \\
\overline{8} .5 \times 10^{-07} \\
\overline{4.8} \times 10^{-0} \\
- \\
\overline{5.9} \times 10^{-00} \\
-\end{array}$ & $\begin{array}{l}\text { ICRP } 1989 \\
\text { ICRP } 1989 \\
\text { ICRP } 1989 \\
\text { ICRP } 1989 \\
\text { ICRP } 1989 \\
\text { ICRP } 1989 \\
\text { ICRP } 1989 \\
\text { ICRP } 1989 \\
\text { ICRP } 1989 \\
\text { ICRP } 1989 \\
\text { ICRP } 1989 \\
\text { DOE } 1988 \\
\text { ICRP } 1989 \\
\text { DOE } 1988\end{array}$ \\
\hline 1301 & $12.36 \mathrm{~h}$ & adult & $\begin{array}{l}\text { ingeation } \\
\text { inhalation }\end{array}$ & $\begin{array}{l}4.3 \times 10^{0} \\
2.5 \times 10^{-0}\end{array}$ & - & $\begin{array}{l}1.4 \times 10^{-4} \\
7.4 \times 10^{-05}\end{array}$ & $\overline{2.2} \times 10^{-00}$ & $\begin{array}{l}\text { DOE } 1988 \\
\text { DOE } 1988\end{array}$ \\
\hline${ }^{131} I$ & $8.04 d$ & $\begin{array}{l}3 \mathrm{mos} \\
1 \mathrm{yr} \\
5 \mathrm{yrs} \\
10 \mathrm{yrs} \\
15 \mathrm{yrs} \\
\text { adult }\end{array}$ & $\begin{array}{l}\text { ingestion } \\
\text { inhalation } \\
\text { ingestion } \\
\text { inhalation } \\
\text { ingestion } \\
\text { inhalation } \\
\text { ingeation } \\
\text { inhalation } \\
\text { ingestion } \\
\text { inhalation } \\
\text { ingestion } \\
\text { ingestion } \\
\text { inhalation } \\
\text { inhalation }\end{array}$ & 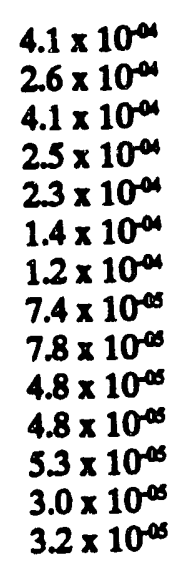 & 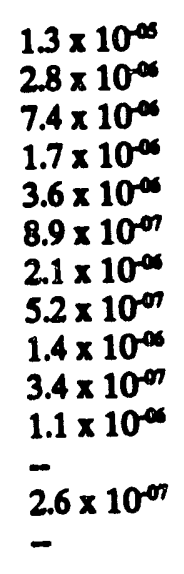 & 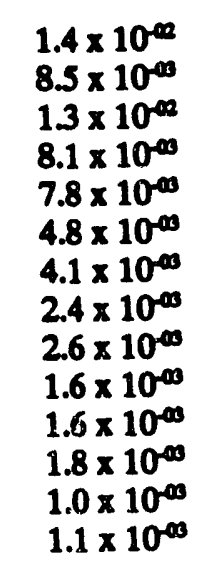 & $\begin{array}{l}\overline{3.3} \times 10^{-00} \\
\overline{2} \\
2.4 \times 10^{-00} \\
\overline{1.4} \times 10^{-00} \\
\overline{8.9} \times 10^{-07} \\
\overline{5} .2 \times 10^{-00} \\
\overline{-} \\
\overline{4.4} \times 10^{-07} \\
-\end{array}$ & $\begin{array}{l}\text { ICRP } 1989 \\
\text { ICRP } 1989 \\
\text { ICRP } 1989 \\
\text { ICRP } 1989 \\
\text { ICRP } 1989 \\
\text { ICRP } 1989 \\
\text { ICRP } 1989 \\
\text { ICRP } 1989 \\
\text { ICRP } 1989 \\
\text { ICRP } 1989 \\
\text { ICRP } 1989 \\
\text { DOE } 1988 \\
\text { ICRP } 1989 \\
\text { DOE } 1988\end{array}$ \\
\hline
\end{tabular}

-EDE = effective dose equivalent. 
Table 5-3. Internal dowe fact : or iodine isotopes (continued)

\begin{tabular}{|c|c|c|c|c|c|c|c|c|}
\hline \multirow[b]{2}{*}{ Irotope } & \multirow[b]{2}{*}{$\begin{array}{l}\text { Radio- } \\
\text { logical } \\
\text { Hialf-life }\end{array}$} & \multirow[b]{2}{*}{$\begin{array}{l}\text { Ase } \\
\text { Group }\end{array}$} & \multirow[b]{2}{*}{$\begin{array}{l}\text { Intaloe } \\
\text { Mode }\end{array}$} & \multicolumn{4}{|c|}{ Dose Factor, mrem/pCl } & \multirow[b]{2}{*}{ Reference } \\
\hline & & & & EDE* & $\begin{array}{l}\text { Stomech } \\
\text { Wall }\end{array}$ & Thyroid & Long: & \\
\hline 1309 & $2.3 \mathrm{~h}$ & $\begin{array}{l}3 \mathrm{mos} \\
1 \mathrm{yr} \\
5 \mathrm{yrs} \\
10 \mathrm{yrz} \\
15 \mathrm{yrs} \\
\text { adult }\end{array}$ & $\begin{array}{l}\text { ingeation } \\
\text { inhalation } \\
\text { ingeation } \\
\text { inhalution } \\
\text { ingeation } \\
\text { inhalation } \\
\text { ingection } \\
\text { inhalation } \\
\text { ingection } \\
\text { inhalation } \\
\text { ingeetion } \\
\text { ingeation } \\
\text { inhalation } \\
\text { inhalation }\end{array}$ & $\begin{array}{l}7.0 \times 10^{-0} \\
3.7 \times 10^{-0} \\
5.6 \times 10^{-0} \\
3.0 \times 10^{-0} \\
2.8 \times 10^{-0} \\
1.6 \times 10^{-0} \\
1.4 \times 10^{-0} \\
8.1 \times 10^{-0} \\
9.3 \times 10^{-0} \\
5.6 \times 10^{-0} \\
6.3 \times 10^{-07} \\
1.0 \times 10^{-0} \\
3.7 \times 10^{-0} \\
3.3 \times 10^{-0}\end{array}$ & 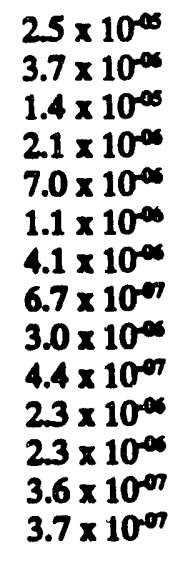 & 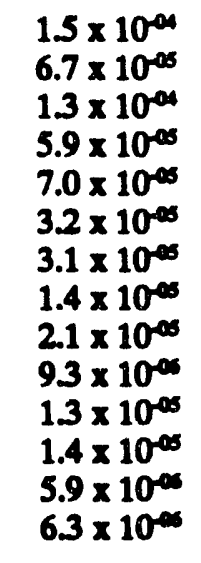 & $\begin{array}{l}\overline{1.1} \times 10^{-00} \\
\overline{7} .4 \times 10^{-00} \\
\overline{3.7} \times 10^{-0} \\
\overline{2} .5 \times 10^{-07} \\
\overline{1.6} \times 10^{-07} \\
\overline{-} \\
\overline{1.3} \times 10^{-07} \\
1.0 \times 10^{00}\end{array}$ & $\begin{array}{l}\text { ICRP } 1989 \\
\text { ICRP } 1989 \\
\text { ICRP } 1989 \\
\text { ICRP } 1989 \\
\text { ICRP } 1989 \\
\text { ICRP } 1989 \\
\text { ICRP } 1989 \\
\text { ICRP } 1989 \\
\text { ICRP } 1989 \\
\text { ICRP } 1989 \\
\text { ICRP } 1989 \\
\text { DOE } 1988 \\
\text { ICRP } 1989 \\
\text { DOE } 1988\end{array}$ \\
\hline 130I & $20.8 \mathrm{~h}$ & adult & $\begin{array}{l}\text { ingection } \\
\text { inhalation }\end{array}$ & $\begin{array}{l}1.0 \times 10^{-06} \\
5.4 \times 10^{-0}\end{array}$ & - & $\begin{array}{l}3.4 \times 10^{-4} \\
1.8 \times 10^{-4}\end{array}$ & - & $\begin{array}{l}\text { DOE } 1988 \\
\text { DOE } 1988\end{array}$ \\
\hline 130I & $52.6 \mathrm{~m}$ & edult & $\begin{array}{l}\text { ingeation } \\
\text { inhalation }\end{array}$ & $\begin{array}{l}1.9 \times 10^{-07} \\
1.1 \times 10^{-07}\end{array}$ & $\begin{array}{l}2.0 \times 10^{00} \\
2.6 \times 10^{00}\end{array}$ & $\begin{array}{l}2.3 \times 10^{00} \\
1.1 \times 10^{00}\end{array}$ & $5.2 \times 10^{01}$ & $\begin{array}{l}\text { DOE } 1988 \\
\text { DOE } 1988\end{array}$ \\
\hline 130I & $6.61 \mathrm{~h}$ & adult & $\begin{array}{l}\text { ingeation } \\
\text { inhalation }\end{array}$ & $\begin{array}{l}2.0 \times 10^{\circ} \\
1.1 \times 10^{\circ}\end{array}$ & - & $\begin{array}{l}6.7 \times 10^{\infty 6} \\
3.1 \times 10^{60}\end{array}$ & $\overline{1.6} \times 10^{\infty}$ & $\begin{array}{l}\text { DOE } 1988 \\
\text { DOE } 1988\end{array}$ \\
\hline
\end{tabular}

-EDE = effective dose oquivalent

The ICRP 1989 inhalation dose factors shown in Table 5-3 were calculated from the lung model of ICRP 1979. The lung model does not make any allowance for age-dependent changes in deposition or clearance of inhaled material. Therefore, the age-dependent inhalation dose factors in the table are considered to be interim valuea. An age-dependent lung model for inhalation doses being developed by ICRP was not yet available for use in this report.

To calculate the committed dose equivalent to specific organs and the committed effective dose equivalent (CEDE) to in individual, SRS dose codes socess dose factor libraries. The libraries contain radionuclide-epecific and expowure pathway-specific factors that express the 50-year committod dose that would result from ine intake of a unit quantity of radiosetivity.

Doses to the offisite population from SRS radioiodine relesses, as presented later in this chapter, were calculated wring both the DOE 1988 and the ICRP 1989 doce conversion factors (Table 5-3). The discusaion of the results, however, focuses on the dose estimates generated with the DOE dose factors because they are generally higher and, therefore, more conservative. 


\section{Models of Radioiodine Transport and Dose}

Concentrations of SRS radioiodine in the offsite environment as of the iate $1980 \mathrm{~s}$ are 80 low that they are not detectable by conventional monitoring techniques. Therefore, radiation doses to offivite individuals and populations are calculated with mathematical modele. These models use known transport mechnnisms for atmospheric and liquid releases and known major pathways of exposure to humans. Modeled atmospheric and aqueous dispersion are periodically verified using environmental messurements of tritium released during normal SRS operations.

\section{Calculational Models}

The firt models used at SRS for calculating offsite doses were developed at SRI (Cooper, 1975). Thewe models, MREM (atmoepheric releases) and RIVDOSE (liquid relenses), were fint used in 1972. In 1982 MREM and RIVDOSE were repleced with more technologically advanced models.

SRS annual officite doses were calculated with the transport and doae modele developed for the commercial nuclear industry (NRC, 1977a; NRC, 1977b). The models were implemented at SRS in the following computer programs:

\section{Atmospheria Releases}

- MAXIGASP: calculates maximum and average doses to offrite individuals

- POPGASP: calculates offeite population doses

\section{Liquid Releases}

- LADTAP II: calculates maximum and average doses to offsite individuals as well as doses to offsite populations

MAXIGASP and POPGASP are SRL-modified versions of the Nuclear Regulatory Commission (NRC) programs XOQDOQ (Sagendorf et al., 1982) and GASPAR (Eckerman et al., 1980). The modifications were made to meet the requirements for input of physical and biological data which are specific to the SRS. The basic calculations in the XOQDOQ and GASPAR programs have not been modified. LADTAP II (Simpson and McGill, 1980) is an esentially unaltered version of the NRC code of the same name.

\section{Modeling Atmospheric Dispersion of Radioactive Releases}

The routine atmospheric transport of radiosctive materials from SRS is evaluated on the basis of meteorologien condition messured continuously at eight meteorological towers, one of which is offaite. The towers relay wind speed and direction and atmospheric ability information at five-econd intervals to SRL through the WIND (Weather Information and Display) syatem. A data base of this information containing the 60-minute average values for the period 1982 - 1986 is soceseed by the dispersion code to determine site-specific atmospheric dispersion chancteristics.

The dispersion of an atmospheric release from SRS is modeled using XOQDOQ, which computes concentration in the plume as a function of downwind distance and compass sector. At the user's option, the plume can be depleted due to dry deposition or radiosctive decay. Also af the user's option, plume concentrations can be reduced by thking into account the upward dieplecement of the plume reaulting from thermal buoyancy or momentum effects. This option is not used at SRS- -0 credit is taken for plume rise.

The plume concentration information generated by XOQDOQ is then used by the dose modeling program GASPAR to extimate doses to offsite individuals and populations.

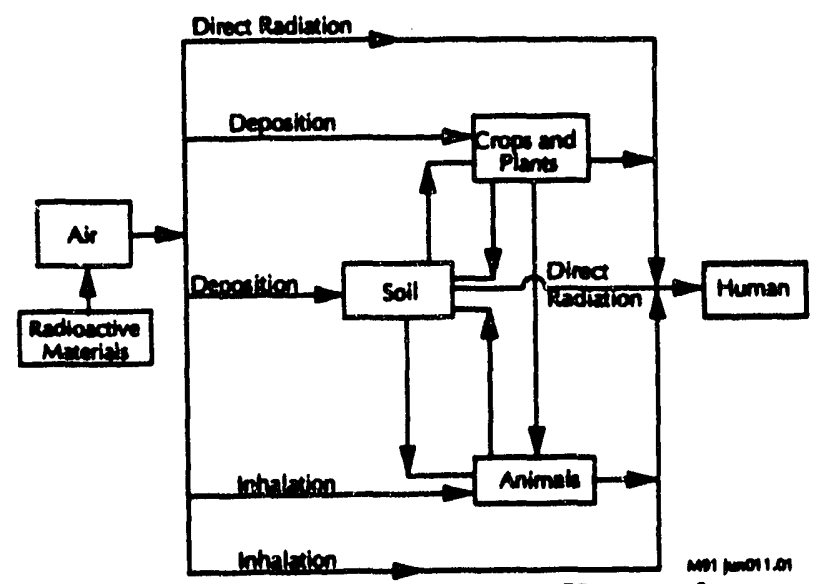

Dature S-2. Simplified Pathways to Humans from Radionctive Materials Relessed to the Atmosphere 
GASPAR extimates doces from a number of pathways which are illustrated in a general sense in Figure 5-2.

The doses extimated by GASPAR are reported on a pethway-specific basis as follows:

- Plume - external dose from radioective materials suspended in the atmosphere

- Ground - external dose from redianctive materials deposited on the ground

- Inhriation - internal dose from inhalation of radioactive materials present in the plume

- Vegetation - internal dose from consumption of contaminated crops

- Milk - internal dose from consumption of milk produced in a contaminated area

- Meat - internal dose from consumption of meat produced in a contaminated area

The method of modeling the concentration of radionctivity as it moves through these pathways is fairly consistent from radionuclide to radionuclide. There is, however, a noteworthy modification made for radioiodine. For doce purposes it is assumed that all of the radioiodine deposited on vegetation is retained by the vegetation. This differs from the retention fraction of 0.2 that is ueed for most other redionuclides.

MAXIGASP. The calculations required by XOQDOQ and GASPAR to extimate maximum and average individual doees are performed at SRS using the computer program MAXIGASP. MAXIGASP calculates annual average ground-level air concentrations and 50-yr committed doses at a number of points along the site boundary in each of 16 compess soctors.

The main outputs from the program are the maximum doce equivalents to an individual along the SRS perimeter. The maximally-exposed individual is assumed to reside continuously at the location of highest exposure and to have living and eating habits that maximize his dose. These aseumptions provide a ceiling on doees from atmospheric releases as no such individual is believed to exist.

The parameters used to calculate doses with MAXIGASP are presented in Table 5-4.

POPGASP. The calculations required by $X O Q D O Q$ and GASPAR to estimate population doses from atmoepheric releases are performed at SRS using POPGASP. POPGASP calculates annual average ground-level air concentrations and annual doses for each of 160 regions (16 wind direction sectors at 10 distances per sector) within an 80-kilometer radius of the release location.

In eddition to compases sector-specific meteorological information, POPGASP ueces sector-specific data on population distribution and composition. Comparable data on milk, meat, and vegetable production and consumption are also ueed in the code. These data bases are quite extensive and are available for review in the SRS environmental reports published annually. With reapect to the human parnmeters used in POPGASP, the key values are shown in Table 5-4. 
Table 5- Sico- and age-epecific parameters for atmospheric relenes

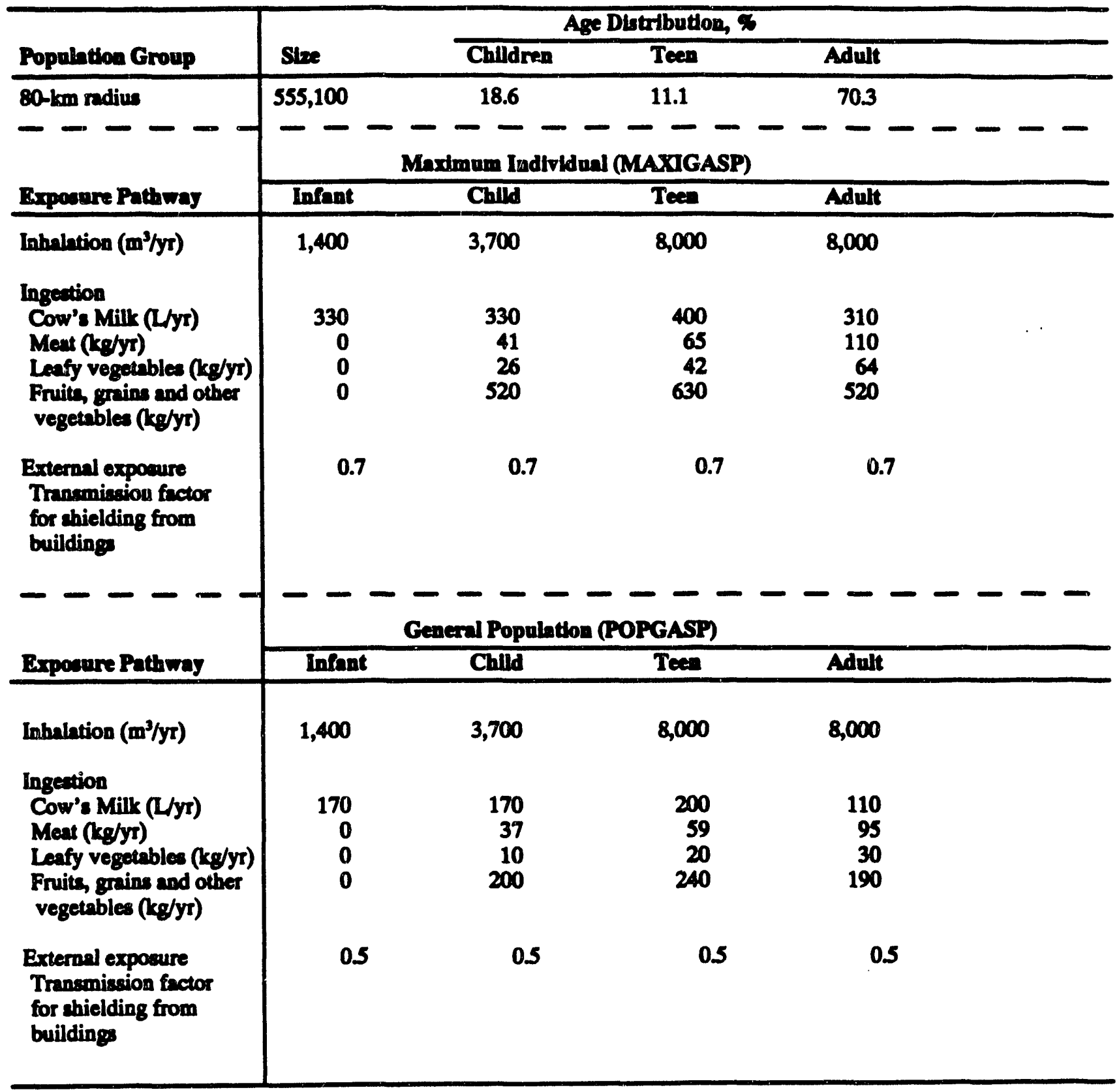

\section{Modeling Doses from Liquid Releases}

The consequences of liquid releases from SRS are modeled using LADTAP II. The potential pethways of exposure from liquid releases to the environment are shown in Figure 5-3. The pathway-specific doeses calculated by LADTAP are grouped into the following five categories:

- Potable drinking water - internal dose from consuming drinking water of Savannah River origin
- Sports fish and commercial fish - internal dose from consuming fish of Savannah River origin

- Salt water invertebrates - internal doce from consuming shell fish from cetuaries of the Savannah River

- Recreation - external dose from recreation sctivities in and along the Savannah River (boating, swimming, and shoreline sctivities) 


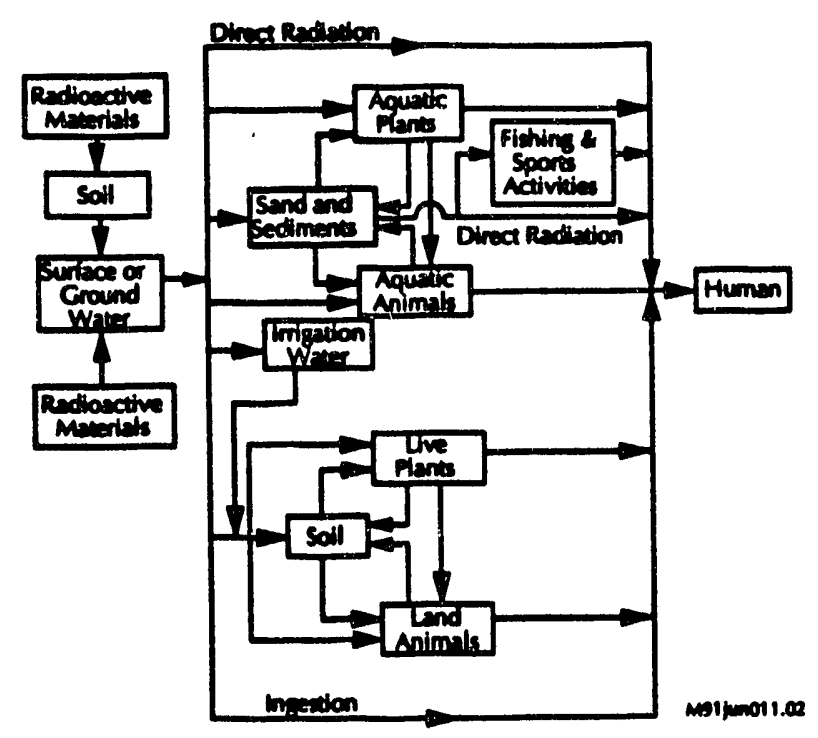

Figure 5-3. Simplified Pathways to Humans from Radionctive Materials Released to Surface or Ground Watere

- Irrigation - internal doee from foods produced by irrigation with Savannah River water (there are no known users of the river for this purpose)
LADTAP otimates individual and population doses at specific downstream locations. The only removal mechanism included in the transport model as it is used at SRS is radiosetive docay. No credit is taken for adsorption of radioiodine on stream sediments.

The major ascumption inherent in the application of LADTAP to SRS releases is that liquid discharges undergo complete mixing in the Savannah River before reaching potentially exposed populations. This assumption is supported by repeated tritium meseurements indicating that complete mixing occurs in the river between the SRS and the Highway 301 sampling station (Cummins et al., 1990a).

LADTAP II generates maximum individual and population doees for all of the exposure pathways identified previously. Though standard input values are provided in LADTAP II, SRS calculations are performed with site-specific information to the extent that it is available. Summary tables of principal input values used in the SRS version of LAD. TAP II are shown in Table 5-5. 
Table 5-5. Sito- and ago-epecific parameters for liquid releases

Maximum Individual Dose Assessments (LADTAP II)

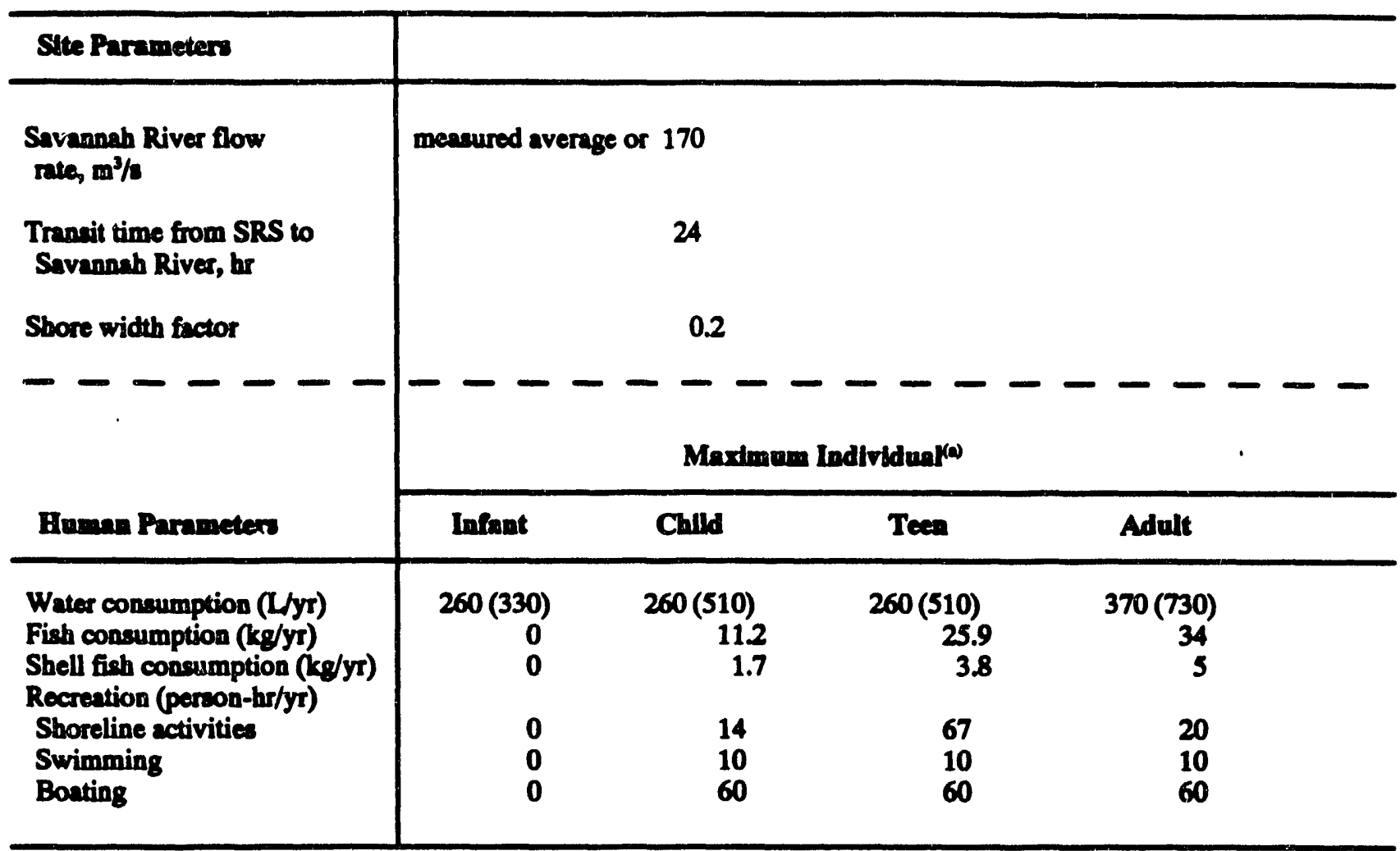

(a) The values in parentheses are EPA parameters mandated for use when calculating maximum individual doses to Beaufort-Jasper and Port Wentworth water users. 
Table 5-5. Silo- and ago-specific panmeters for liquid releases (continued)

Population Doce Accessments (LADTAP In)

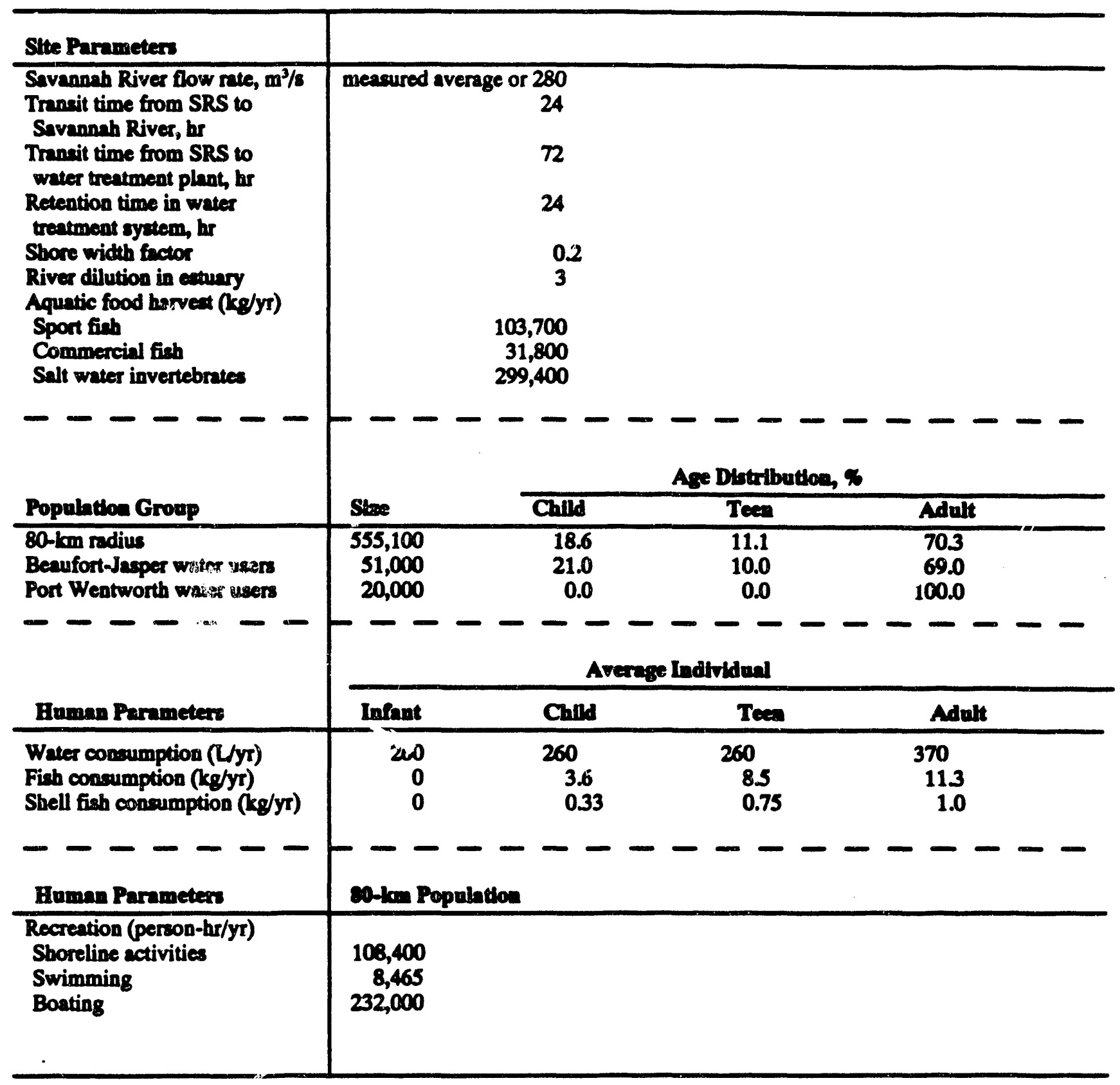


Table 56. Maximum individual doses from atmospheric releases of 129$)(1955 \cdot 1989)$

\begin{tabular}{|c|c|c|c|c|c|c|c|c|c|c|c|}
\hline \multirow[b]{2}{*}{ Year } & \multirow{2}{*}{$\begin{array}{l}\text { Releases } \\
\text { (auries) }\end{array}$} & \multicolumn{2}{|c|}{$\begin{array}{l}\text { ICRP } 30 \\
\text { Aduk Dose (mrem) }\end{array}$} & \multicolumn{2}{|c|}{$\begin{array}{l}\text { ICRP } 56 \\
\text { Aduth Dose (mrem) }\end{array}$} & \multicolumn{2}{|c|}{$\begin{array}{l}\text { ICRP } 56 \\
\text { Teen Dose (mrem) }\end{array}$} & \multicolumn{2}{|c|}{$\begin{array}{l}\text { ICRP 56 } \\
\text { Child Dose (mrem) }\end{array}$} & \multicolumn{2}{|c|}{$\begin{array}{c}\text { ICRP } 56 \\
\text { Infant Dose (mrem) }\end{array}$} \\
\hline & & EEE & Thyroid & EDE & Thyroid & EDE & Thyroid & EDE & Thyroid & EDE & Thyroid \\
\hline $\begin{array}{l}1955 \\
1956 \\
1957 \\
1958 \\
1996 \\
1960 \\
1961 \\
1962 \\
1963 \\
1964 \\
1965 \\
1966 \\
1967 \\
1968 \\
1969 \\
1970 \\
1971 \\
1972 \\
1973 \\
1914 \\
1975 \\
1976 \\
1977 \\
1978 \\
1979 \\
1900 \\
1981 \\
1980 \\
1983 \\
1984 \\
1985 \\
1906 \\
1987 \\
1988 \\
1999 \\
\end{array}$ & 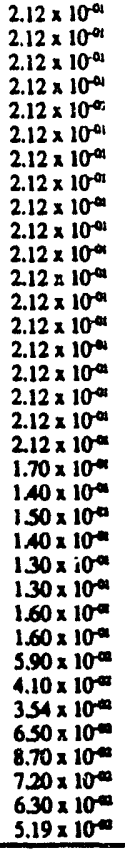 & 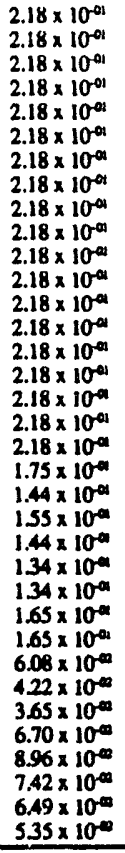 & $\begin{array}{l}7.21 \\
7.21 \\
7.21 \\
7.21 \\
7.21 \\
7.21 \\
7.21 \\
7.21 \\
7.21 \\
7.21 \\
7.21 \\
7.21 \\
7.21 \\
7.21 \\
7.21 \\
7.21 \\
7.21 \\
7.21 \\
7.21 \\
5.78 \\
4.76 \\
5.10 \\
4.76 \\
4.42 \\
4.42 \\
5.44 \\
5.44 \\
2.01 \\
1.39 \\
1.20 \\
2.21 \\
2.96 \\
2.45 \\
2.14 \\
1.76 \\
\end{array}$ & 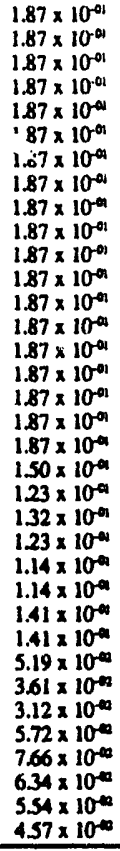 & $\begin{array}{l}6.04 \\
6.04 \\
6.04 \\
6.04 \\
6.04 \\
6.04 \\
6.04 \\
6.04 \\
6.04 \\
6.04 \\
6.04 \\
6.04 \\
6.04 \\
6.04 \\
6.04 \\
6.04 \\
6.04 \\
6.04 \\
6.24 \\
4.85 \\
3.99 \\
4.28 \\
3.99 \\
3.71 \\
3.71 \\
4.56 \\
4.56 \\
1.68 \\
1.17 \\
1.01 \\
1.85 \\
2.48 \\
2.05 \\
1.80 \\
1.48 \\
\end{array}$ & 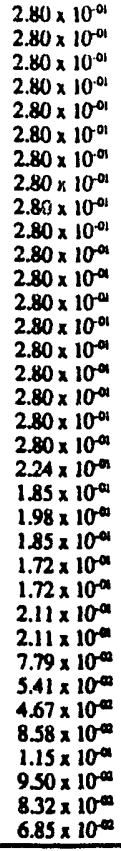 & $\begin{array}{l}8.95 \\
8.95 \\
8.95 \\
8.95 \\
8.95 \\
8.95 \\
8.95 \\
8.95 \\
8.95 \\
8.95 \\
8.95 \\
8.95 \\
8.95 \\
8.95 \\
8.95 \\
8.95 \\
8.95 \\
8.95 \\
8.95 \\
7.17 \\
5.91 \\
6.33 \\
5.91 \\
5.49 \\
5.49 \\
6.75 \\
6.75 \\
2.49 \\
1.73 \\
1.49 \\
2.74 \\
3.67 \\
3.04 \\
2.66 \\
2.19 \\
\end{array}$ & 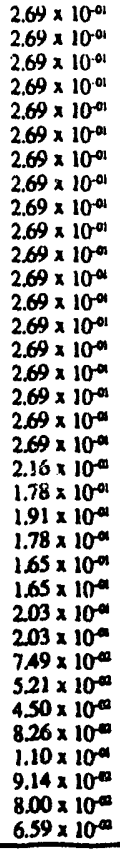 & $\begin{array}{l}9.43 \\
9.43 \\
9.43 \\
9.43 \\
9.43 \\
9.43 \\
9.43 \\
9.43 \\
9.43 \\
9.43 \\
9.43 \\
9.43 \\
9.43 \\
9.43 \\
9.43 \\
9.43 \\
9.43 \\
9.43 \\
9.43 \\
7.57 \\
6.23 \\
6.68 \\
6.23 \\
5.79 \\
5.79 \\
7.12 \\
7.12 \\
2.63 \\
1.82 \\
1.58 \\
2.89 \\
3.87 \\
3.20 \\
2.80 \\
2.31 \\
\end{array}$ & 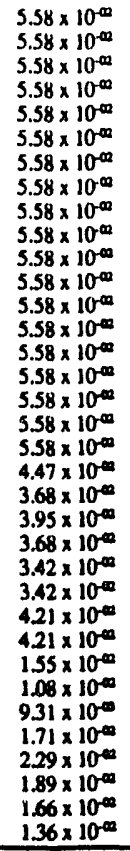 & $\begin{array}{l}1.83 \\
1.83 \\
1.83 \\
1.83 \\
1.83 \\
1.83 \\
1.83 \\
1.83 \\
1.83 \\
1.83 \\
1.83 \\
1.83 \\
1.83 \\
1.83 \\
1.83 \\
1.83 \\
1.83 \\
1.83 \\
1.83 \\
1.47 \\
1.21 \\
1.30 \\
1.21 \\
1.12 \\
1.12 \\
1.38 \\
1.38 \\
0.51 \\
0.35 \\
0.31 \\
0.56 \\
0.75 \\
0.62 \\
0.54 \\
0.45 \\
\end{array}$ \\
\hline Tow & 5.67 & 5.85 & $1.94 \times 10^{2}$ & 5.00 & $1.62 \times 10^{2}$ & \multicolumn{2}{|c|}{$N / 4$} & \multicolumn{2}{|c|}{ N/A } & \multicolumn{2}{|l|}{ N/A } \\
\hline
\end{tabular}


Table 5-7. Maximum i idividual doses from atmospheric releayes of "1"I(1955 - 1989)

\begin{tabular}{|c|c|c|c|c|c|c|c|c|c|c|c|}
\hline \multirow[b]{2}{*}{ Year } & \multirow{2}{*}{$\begin{array}{l}\text { Releases } \\
\text { (couries) }\end{array}$} & \multicolumn{2}{|c|}{$\begin{array}{l}\text { ICRP } 30 \\
\text { Adulf Dowe (mrem) }\end{array}$} & \multicolumn{2}{|c|}{$\begin{array}{l}\text { ICRP } 56 \\
\text { Mduht Dose (mrem) }\end{array}$} & \multicolumn{2}{|c|}{$\begin{array}{l}\text { ICRP } 56 \\
\text { Teen Dose (mrem) }\end{array}$} & \multicolumn{2}{|c|}{$\begin{array}{l}\text { ICRP } 56 \\
\text { Chidd Dose (mrem) } \\
\end{array}$} & \multicolumn{2}{|c|}{$\begin{array}{l}\text { TCRP } 56 \\
\text { Intant Dose (mnem) }\end{array}$} \\
\hline & & EDE & Thyrade & EDE & Tinrodd & EDE & Throfd & EDE & Thrrad & EDE & inmon \\
\hline $\begin{array}{l}1955 \\
1956 \\
1957 \\
1958 \\
1959 \\
1960 \\
1961 \\
1962 \\
1963 \\
1964 \\
1965 \\
1966 \\
1967 \\
1968 \\
1969 \\
1970 \\
1971 \\
1972 \\
1973 \\
1974 \\
1975 \\
1976 \\
1977 \\
1978 \\
1979 \\
1990 \\
1991 \\
1902 \\
1983 \\
1994 \\
1985 \\
1996 \\
1987 \\
1998 \\
1949 \\
\end{array}$ & 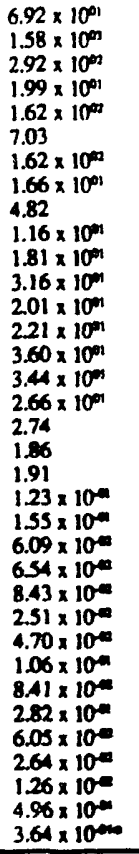 & 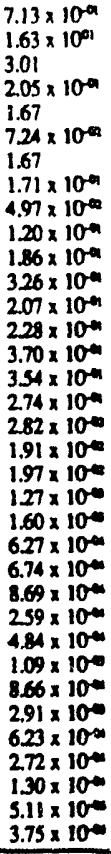 & $\begin{array}{l}2.42 \times 10^{\infty 1} \\
5.51 \times 10^{\infty} \\
1.02 \times 10^{\infty} \\
6.96 \\
5.66 \times 10^{\infty 1} \\
2.45 \\
5.65 \times 10^{\infty 1} \\
5.81 \\
1.68 \\
4.05 \\
6.31 \\
1.10 \times 10^{\circ} \\
7.01 \\
7.72 \\
1.25 \times 10^{\infty} \\
1.20 \times 10^{\infty} \\
9.29 \\
9.57 \times 10^{\infty} \\
6.48 \times 10^{\infty} \\
6.68 \times 10^{\infty} \\
4.31 \times 10^{\infty} \\
5.43 \times 10^{\infty} \\
2.12 \times 10^{\infty} \\
2.28 \times 10^{\infty} \\
2.94 \times 10^{\infty} \\
8.77 \times 10^{\infty} \\
1.64 \times 10^{\infty} \\
3.70 \times 10^{\infty} \\
2.93 \times 10^{\infty} \\
9.86 \times 10^{\infty} \\
2.11 \times 10^{\infty} \\
9.21 \times 10^{\infty} \\
4.40 \times 10^{\infty} \\
1.73 \times 10^{\infty} \\
1.27 \times 10^{\infty}\end{array}$ & 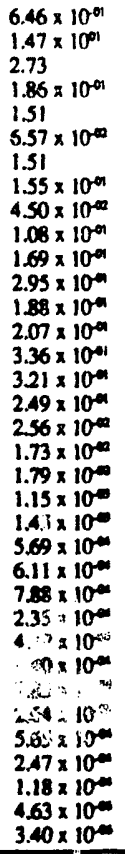 & 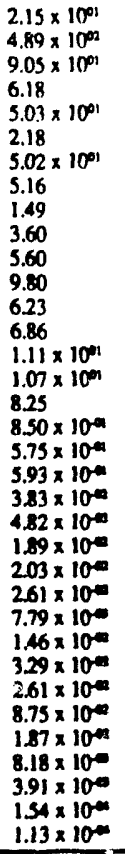 & 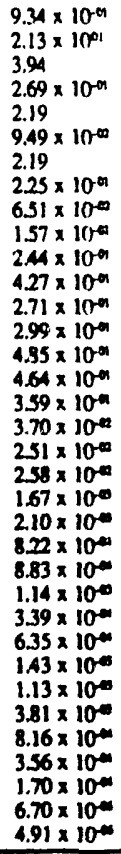 & 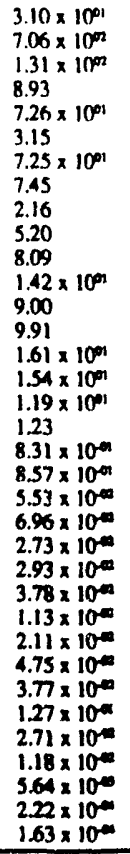 & 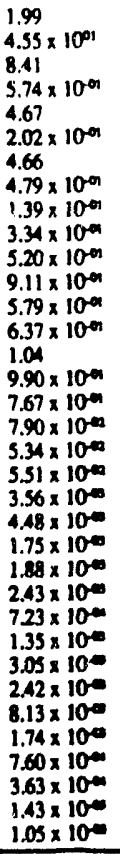 & 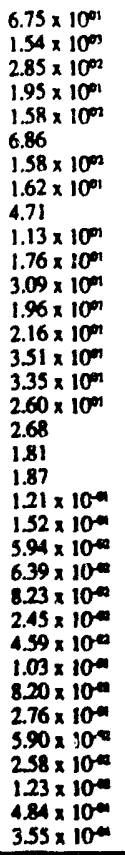 & 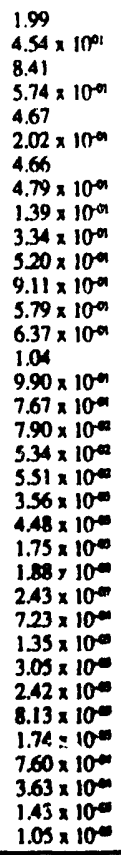 & 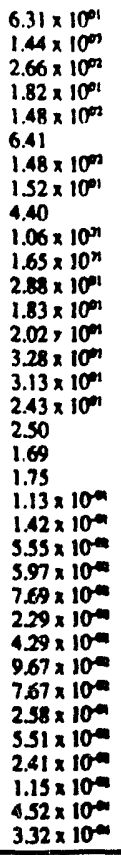 \\
\hline Towal & $252 \times 10^{\circ}$ & $200 \times 10^{m}$ & $8200 \times 10^{00}$ & $235 \times 10^{m}$ & $781 \times 10^{9}$ & $\mathbf{N}$ & & $N / A$ & & $N / A$ & \\
\hline
\end{tabular}


Table 54. Population doses from atmospheric radioiodine releases (1955 - 1984)

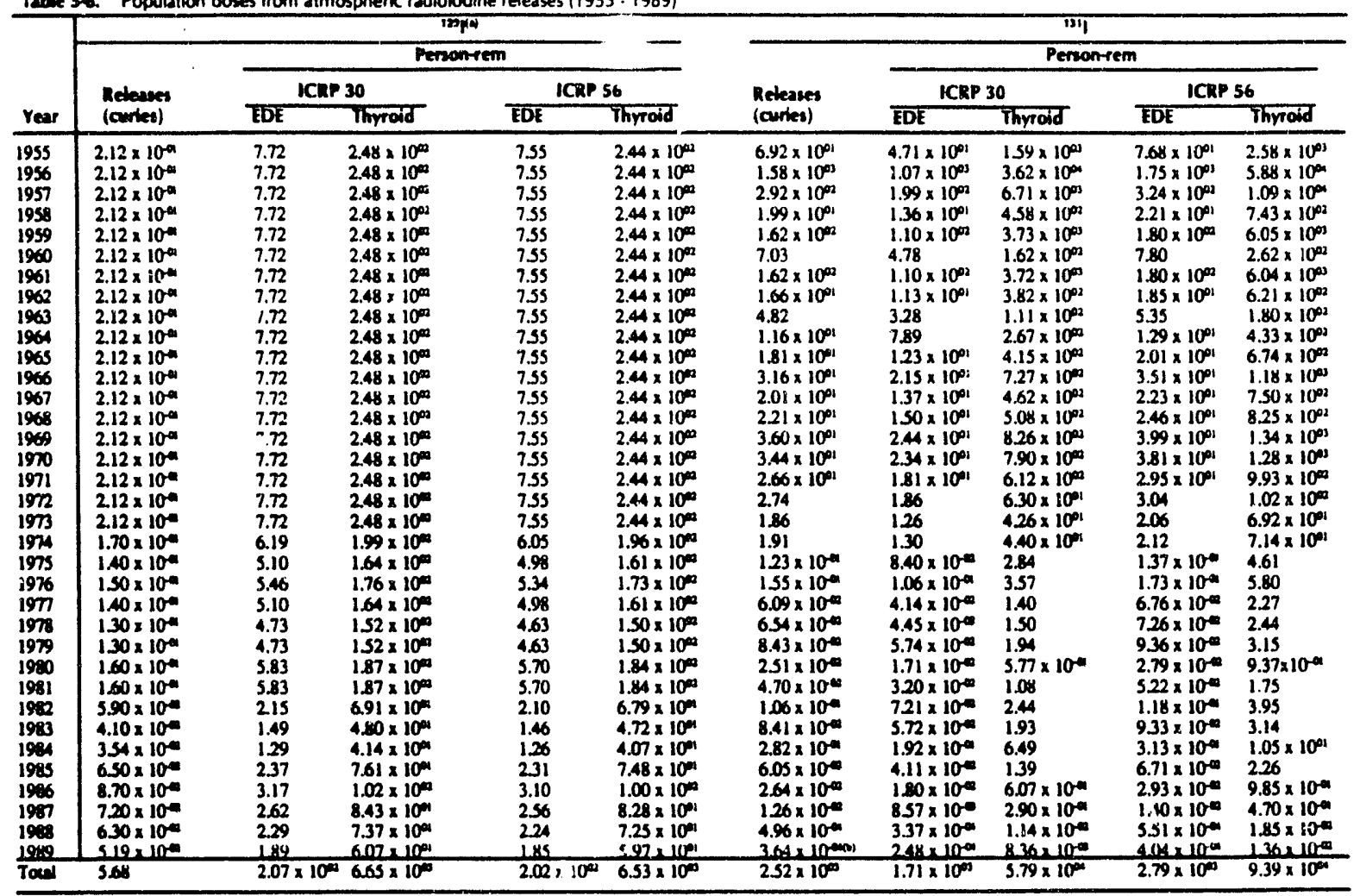

wDomes for 1955 through 1973 reflect aresued average relasess for this period.

ine ropored 1969 releare was recvelumed to have been $3.45 \times 10^{-}$

EDEne effective done equaviles 


\section{Verification of Models Using Measurement Data}

Model are verified with environmental measuremen ts of tritium. Tritium is routinely detected offeite uaing conventional mensuring techniques.

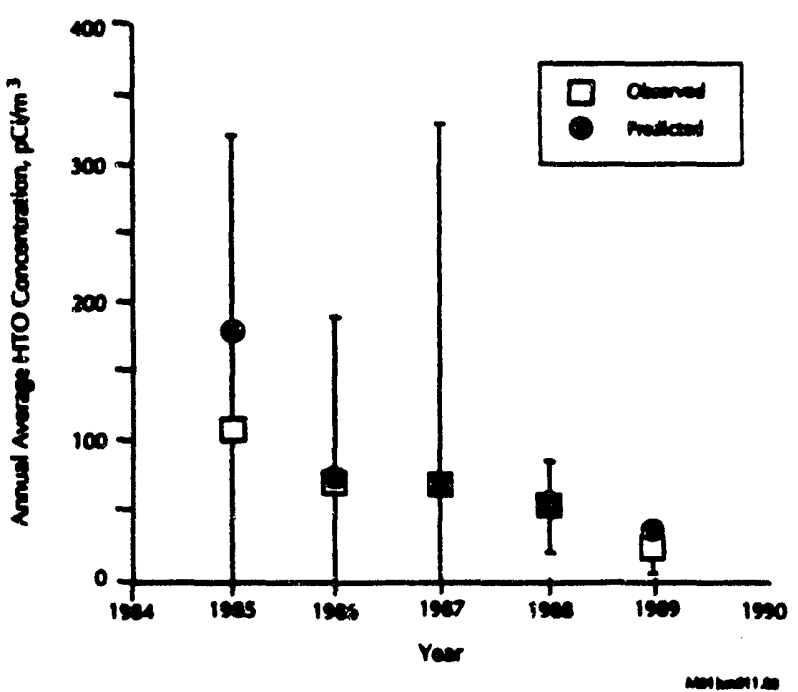

Fegures-4. Comparicon of Prodictod and Measured Tritium Concentration in Air at the Site Perimeter $( \pm 2$ Standard Deviation at the 95 Percent Confidence Level)

\section{Atmospheric Releases}

The redionuclide concentrations predicted by XONDOQ are routinely compared with measured values of tritium concentrations in air to evaluate the performance of the code. Figure 5-4 shows a comparicon of calculated and measured tritium oxide concentrations in air at the site perimeter. As scen in the figure, predicted values tend to exceed observed values, yet not ? . degree that would indicate an exceseively conservative sppronch.

Other comparisons of prodicted and measured concentrntions have been made (Murter, 198: ad have exhibited similar revults. The available data wueget that calculated concentrations of tritium in air are generally sonservative eatimates of actual offsite values.

\section{Liquid Releases}

Throughout the period 1954-1989, drinking water doees from routine SRS releases have been dominated by tritium. Measured, rather than eatimated, tritium concentrations are therefore ued for the dowariver locations that are moet important in terms of doce calculations: (1) jua below SRS, (2) at the Beaufort-Jasper water trantmeat plant, and (3) af the Pont Wentworth water treatment plant. In addition to aupplying measured tritium coscentratiom, wuch data also provide Savananh River dilution factors for these locations. The availability of cocurate extimutes of river dilution churncteriatics significandly entunoces LADTAP's ability to predict dowrriver coscentrations of other radionuclides auch as redioiodine.

\section{Impact of SRS Radioiodine Releases on the Offsite Population}

The computer codes MAXIGASP, POPGASP, and LADTAP II are used to calculate effective sod thyroid dose equivalents that have been theoretically received by segments of the offrite population from radioiodine $\left({ }^{2}{ }_{2},{ }^{13}\right)$ expoeure over the cource of site operntions. The reaults are shown are in tables 5-6 through 5-8 for doces attributable to astronispheric releasea and tables 5-9 through 5-11 for doses from liquid releases to

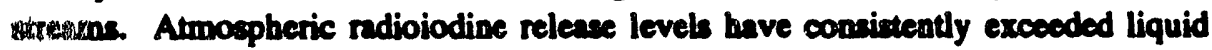
release levels to streame, and this trend is reflected in the calculated doses to the offisite populations.

\section{Doses from Atmospheric Releases}

Dowes due to atmoepheric releasen of ratioiodine are discuesed in term of routine relesses and the 1961 scute releare incident.

\section{Routine Releases}

Dowes to individuals from ${ }^{12} 1$ and ${ }^{131} I$ are shown in tables 5-6 and 5-7, reapectively. As shown in Table 5-7, the largeat ennual effective doce equivalent theoretically received by 
an adult occurrod in 1956, the year atmoepheric ${ }^{131}$ I releases peaked. The effective and thyroid doac equivalents from ${ }^{131}$ I to the "maximum" adult at the site perimeter in 1956 were 16 and 551 mrem, respectively. The dowes to other age grouph calculated with ICRP Publication 56 methodology (ICRP, 1983) were higher because of biokinetic and dietary differences. The age group moet impacted was children. The effective and thyroid dose equivalents from ${ }^{131}$ I to the "maximum" child at the site perimeter in 1956 were 46 and 1540 mrem, respectively.

"Maximum" individuala are hypothetical persons who lived at the SRS boundary and subsisted on diets of locally produced mills, meat, and vegetables. No such individuais are known to exist. Neverthelese, if one exumines the case of the muximum adult individual living continuously at the site perimeter hroughout the period 1955-1989, the cumuiative effective dose equivalent from atmoepheric ${ }^{22 I}$ and ${ }^{131}$ I releasea is catimated as 32 mrem (tables 5-6 and 5-7). This value is believed to represent the bounding case for an adult's iodine doee and would make a minor contribution to the overall dose received during that time period.

A person who was an infant or a child in the 1950 s would have cumulative effective and thyroid dose equivalents somewhat higher than a person who was an adult in the 19503. These doses would depend on the age of the individual at the time of the maximum releases. The maximum possible cumulative dose equivelents would be recejved by a person who was a child in 1955 and who lived at the point along the site boundary having the maximum concentration throughout the 35-year period 1955-1989. The cumulative effective and thyroid dose equivalents to this hypothetical person from ${ }^{129}$ I and ${ }^{131}$ I relesses would be 77 and 2,610 mrem, respectively.

A person living in the Central Savannab River Area would have received an effective dose of approximately 10,300 mrem from exposure to natural sources of radioactivity and an additional 2,300 mrem from modical practices and various consumer products during this 35-year period (Cummins et al, 19906). Therefore, the SRS atmospheric radioiodine releases contributed less than an estimated 0.6 percent of the total cumulative dose to this individual even if the individual was a child in 1955.

Because the contribution of SRS radioiodine releases to any one individual's total radiation dose is so small, it is necessary to pool the radiation expoeures from a given population if an asseasment of potential bealth risks is desired. The population dose within an 80-kilometer radius is a figure-of-merit frequently used to make such on ssessment.
The population doeces reported in Table 5-8 are based on 1980 census date $(555,100$ people within $80 \mathrm{~km})$ and the most recently available meteorological and dose factor data. If it is assumed that this population has lived in the SRS vicinity throughout the period of site operation, the total colloctive effective dose received by that population would be 3,000 person-rem, due to SRS redioiodine relesses through 1989. As indicated in the table, this value is dominated by the ${ }^{131}$ I component of the doee, 2,790 person-rem.

The risks associatod with this collective dose are quite small. The ICRP nominal risk eatimate for the number of excess fatal cancers potentially inducad by a collective dose of 3,000 person-rem is 1.5 . Conversely, in that small population, at the esirrent fatal cancer frequency of 16 percent (EPA, 1989), there will be approximately 90,000 spontaneous fatal cancen from all otber causes. Therefore, it is very unlikely that a relationship between any of the cancer deaths occurring in this population and the releases of radioiodine to the atmouphere from the SRS will be encountered.

\section{Acute ${ }^{131}$ / Release Incident of 1961}

Of the 162 curies of ${ }^{231}$ I released in 1961, 153 curies were releaced from the F-Area chemical separations facility during May 29 - June 23, 1961, as a rewult of the unintentional reprocessing of very short-cooled material (Marter, 1963). About 67 percent (103 curies) of the ${ }^{131}$ I was released during the first eight days. Prevailing southweat winds and atmospheric inversions dispened the radioiodine mainly to the northeast of the site where it was detected in air, vegetation, and food.

Serial sampling showed that the effective half-time of ${ }^{131} I$ in vegetation and milk was 4 to 5 days. The maximum concentration of ${ }^{131} I$ in milk from sampling 48 farms and dairies during the peak period of June 5 and 6 was 5,451 pCi/L. The maximum sample was obtained from a farm approximately $3 \mathrm{~km}$ northeast of the site perimeter.

The only other fresh, locally produced foods available during this period in early June were eges and peaches. Fresh ege from the furm where the maximum milk concentration was found contained an average of 33 PCi/egg. Peaches from an area of high deposition showed no evidence of radioiodine.

The greatest concentrations of ${ }^{131} \mathrm{I}$ in air for the period of maximum releare (May 30 - June 7) ranged from 1 to 5 $\mathrm{pCi} / \mathrm{m}^{3}$. 
From the concentration dath, it wes obviou that the milk pathway would be the major source of offitite exposure. To avoid underetimnting the dose from the ingestion of milk, originnl dose calculations were made with an ascumed 8-day half-time of ${ }^{21} I$ in milk inetend of the S-dyy half-time actuntly observed (Marter, 1963). The original dose calculations indicated the maximum probable dose of 1,200 mrem to a child's thynoid and 140 mrem to an adult's thyroid.

Dose ealculations for food conmumption were based on the

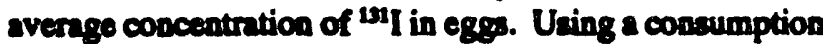
rite of 2 eges per day and en aseumed 5-day half-time in egas, the dose to a child and a tult thyroid would have been 7.1 and 0.7 mom, repectively.

Immercion (plume) thyroid doses from one week of exporure to sir contaminated with 1 io $5 \mathrm{pCi} / \mathrm{m}^{3}$ of ${ }^{131}$ I would have ranged from $4 \times 10^{5}$ to $2 \times 10^{4}$ mrem. Thyroid doses from inhulation of this air would have ranged from 1.4 to 6.9 mrem for a child and 0.3 to 1.5 for an sdult.

Based on this discussion of ${ }^{131}$ I doses from various pathways greater than 95 percent of the thyroid dose for a child and an actult would have reaulted from the millk pathway.

Thyroid doses from the mills pathway were recalculated (Marter, 1990) with a more recent internal dosimetry method (ICRP, 1989) and the cbeerved half-time of ${ }^{131}$ I in milk of 5 days. Meximum doses were reduced 10277 mrem to a child thyroid and 53 mrem to an adult thyroid. In addition, doses of 497 mrem to an infent thyroid and 112 mrem to a teen thyroid were calculated with the current methodology.

Regardleas of the methodology, the calculated thyroid doses: from the 1961 scute release incident are leas than the thyroid doees from routine releases in 1956, the year of maximum 131I releases.

\section{Doses from Liquid Releases}

Dose equivalents potentially received by downetrenm consumers of Savannth River water and fich are shown in tables 5-9, -10, and -11. The dose culculations are baped on the total measured curies of ${ }^{131}$ I relensed directly to onsite streams.

Dase equivalents have been calculated for a "maximum" individual living jus below the SRS. This in an adult who aubaists on a diet of untreated Savannch Rjver water and fich of Savannh River origin. The individual partakes in recreational activitiea in and along the river just below SRS. Dosen to this adult are believed to represent the bounding case for liquid radioiodine relenses (Table 5-9). Drinking water dones have also been calculated for age-specific maximum individuals at the downriver water treatment plants (Table 5-10) and for the populations served by the water trentment plants (Table S-11).

Dose contributions from ${ }^{120}$ have not been included in the tables. The total amount of 121 that migrated to treams throughout the 35-year period has been ectimated $250.2 \mathrm{Ci}$ and is therefore not a significant contributor to dose.

Table 5-9 shows that the muximum doses occurred in 1957, a year of relotively high ${ }^{211}$ I releases coupled with bow river flow rates. The effective and thyroid dose equivalents to the maximum individual for that year are eatimated as 0.4 and 13.7 mrem, reppectively. If the hypothetion "muximum" expoenure conditions are usod as the bounding case for the 35-year period of site operation comidered here, the cumulative effective and thyroid dowes to auch an individual would be on the order of 1.4 and 47.6 mrem, reapectivelynone of which was delivered after 1978.

Racaune this individual's dose from son-SRS sources of radintion for that ame time period would have excoeded 12,000 mrem, it may be concluded that the contribution to downetrenm individuals' doses by SRS rndioiodine releanes is imignifican. This concluaion is further evidenced by the fact that wont of the age-specific annul effective doses reported in tubles $5-9$ and $5-10$ do not exceed 1 mrem. An effective doae equivilent of $<1$ mrem/yr. has been termod a Negligible Individual Rirk Level by the National Council on Radiation Protection and Mearurements (NCRP, 1987). In three cases offective dose equivalent does excead 1 mrem. The greateat value is 1.2 mrem to an infint in 1957.

With respect to the effect of liquid ${ }^{231}$ I relenses on the populations dowariver from SRS, drinking water doese for usen of the Benufort-Jeeper, SC, and Port Wentworth, GA, water treatment plants huve also been extimated. Different terminology is used to dencribe the two population to reflect the difference in their composition. The BanufortJasper plant (51,000 customere) servioes residential areas and therofore provides full-ecale domentic water service. The Port Wentworth facility (20,000 effective consumen) serves a commencial complex in which contact with treated Savannat River water is limited to induetrial workens who consume tap water. In pax years, bowever, a locilly-operated sof drink bouling fecility may have presented an additiond pathway of expocure.

If the cumulative effective doses received by both of these wher-consuming populations are ammed, the collective 
dose equivalent would be 13 peroon-rem. Using the ICRP nominal risk factor, the predicted impect of this collective dose is on eximnted 0.007 excens fat cancen in a population of 71,000 people - 11,400 of whom, at the current fathl enncer rate, are projected to anceumb to cancer from all other sources.
The maximum indivichal exposure is to the water consumer who was an infant in 1957. If that person continued to consume treated Savannah River water, the cumulative effective and thyroid doses would be 3.7 and 123 mrem, respectively - none of which was delivered after 1978.

Table S-9. Liquid "Ireleases and dones to the SRS "maximum" individual()

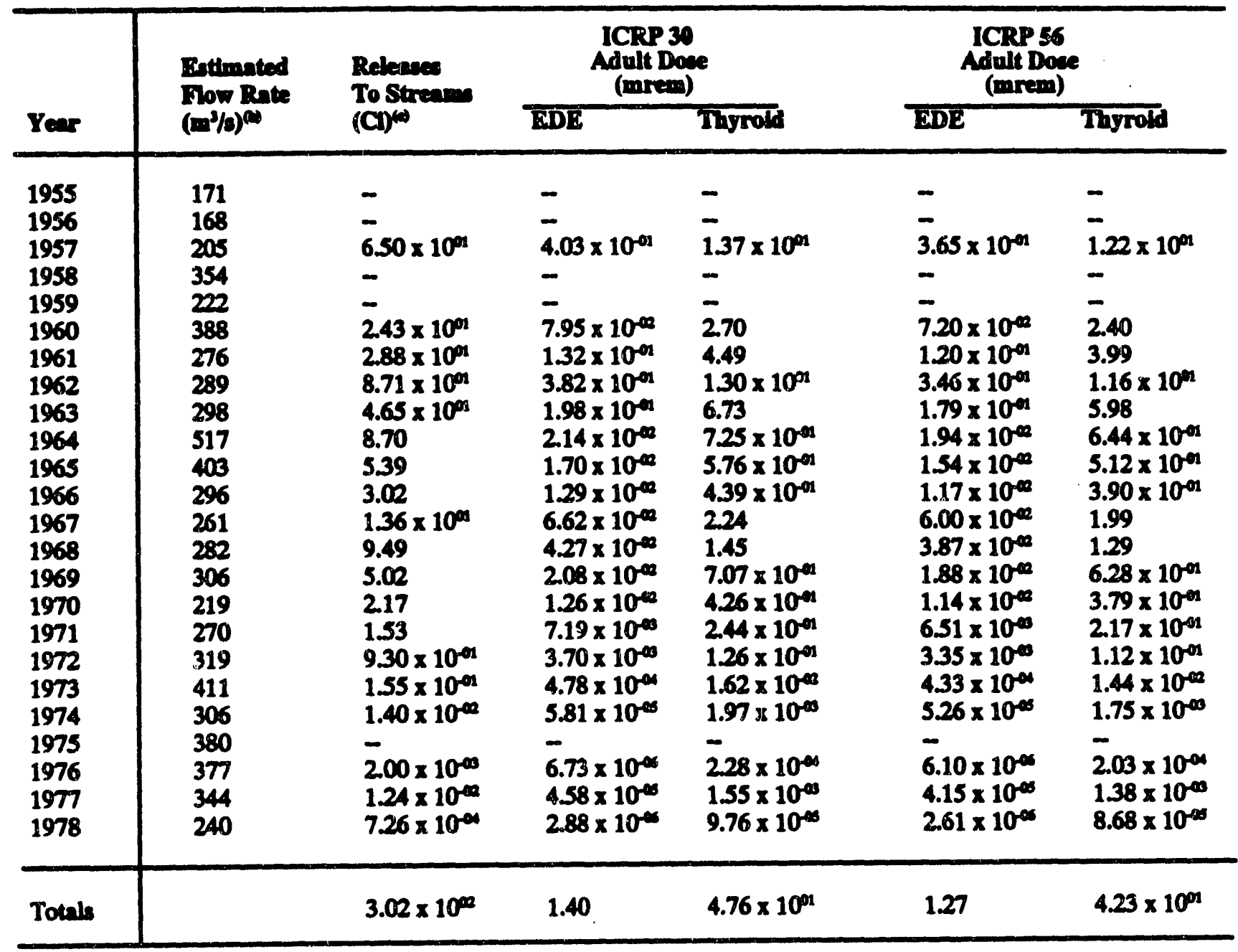

(a) Throughout 1955-1989, approximately $0.2 \mathrm{Ci}$ of ${ }^{12} \mathrm{I}$ migrated to streams. The ${ }^{12} \mathrm{I}$ did not significantly contribute to offisite doses.

(1) Flow rate data based on USGS measurements at Augusta, GA (1954-1972) and the SRS bont dock (1973-1978).

(c) No direct ${ }^{251}$ I relenses to streams after 1978. Total does not include 1 curie from beat exchangers, lenks, and sumps.

DDE = effective dose equivilent 
Table 5-10. Liquid "II doses to "maximum" individuals at the downriver water trearment plants

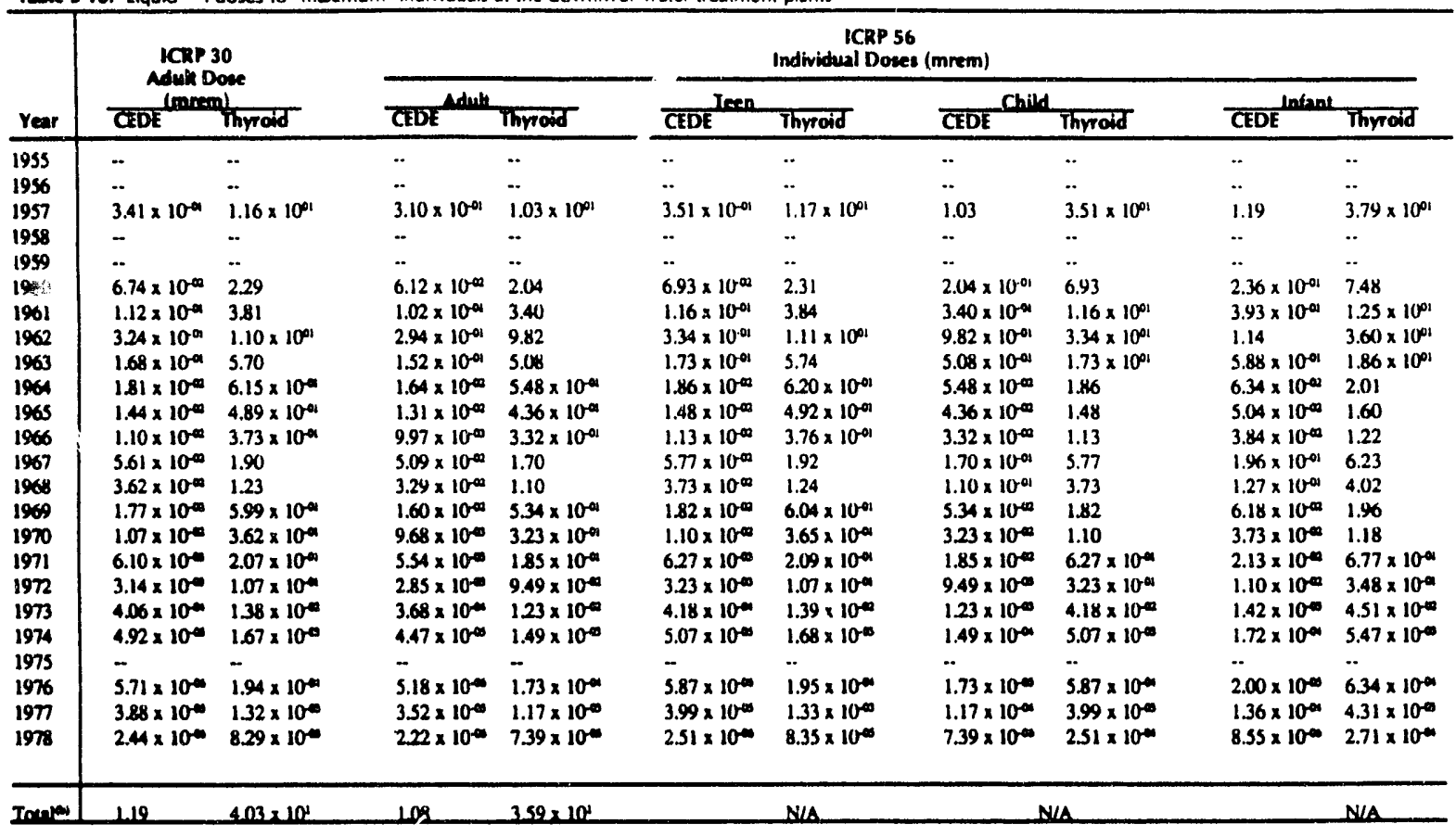

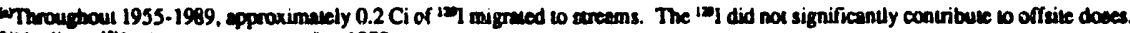
WNo direct '1"I releanes lo streams afiver 1978.

CEDE = commined effocive dome cquivatent

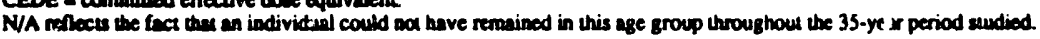


Table 5-11. Liquid 19I doses to populations served by downriver water treatment planto(o)

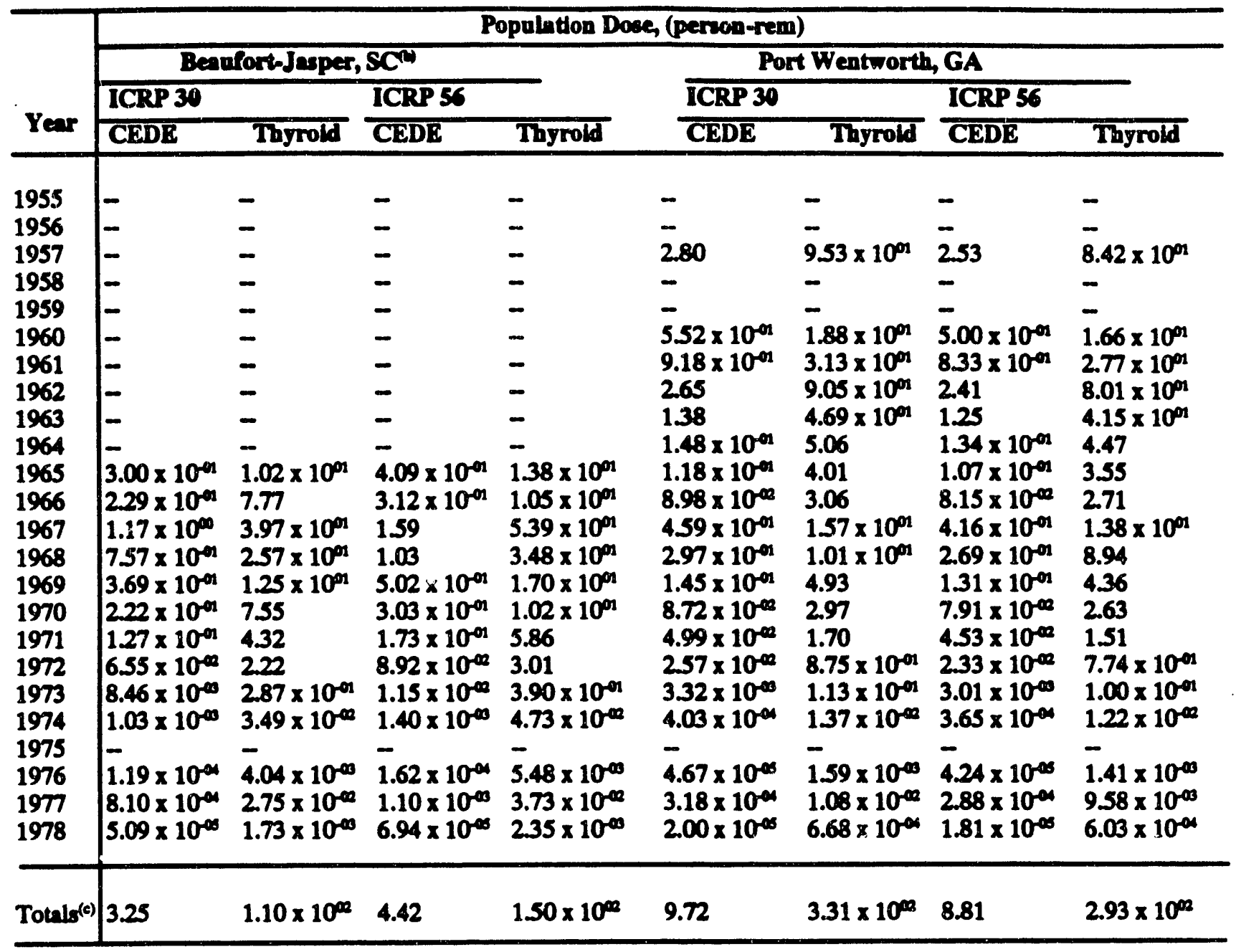

(1) Throughout $1955-1989$, approximately $0.2 \mathrm{Ci}$ of ${ }^{120} \mathrm{I}$ migrated to streams. The ${ }^{120} \mathrm{I}$ did not significantly contribute to iffsite doses.

(0) The Beaufort-Jasper water treatment piant did not operate prior to 1965.

(s) No direct ${ }^{131}$ I releases to streams after 1978.

CEDE = committed effective dose equivalent 


\section{Comparisons of Radioiodine Concentrations and Doses with Applicable Regulations}

EPA and DOE standards are the regulations by which concentrations and doase due to SRS releases are compared. The standards are applicable to air and drinking water.

\section{Concentrations and Doses in Air}

Atmospheric concentrations at the site perimeter are modelled with computer codes because ${ }^{131}$ I has not been routinely detectable since 1963 and routine analyzis of ${ }^{121}$ was not performed. For 1989, the average annual perimeter concentrations of ${ }^{20 I}$ and ${ }^{131} \mathrm{~L}$, as predicted by XOQDOQ, were $1.4 \times 10^{-3}$ and $3.8 \times 10^{-7} \mathrm{pCi} / \mathrm{m}^{3}$, respectively. These values represent leas than one millionth of the DOE and EPA derived air concentration guides for these radionuclides (see Trble 5-12).

In 1956, the your of greateat atmospheric release of ${ }^{131} \mathrm{~L}$, the average annual perimeter concentration would have been $0.4 \mathrm{pCi} / \mathrm{m}^{3}$. This greated concentration is only 0.1 per cent of the DOE guide in effoct during 1989. However, these concentration guides only ensure that the annual effective dose equivalents to members of the public from the inhalation of radioiodine are $<100$ mrem/yr. As all reasonably achievable steps are taken to ensure that environmental doses are only small frections of the dose limit, it is reseonable to expect offaite air concentrations to be quite amall frections of the allowable concentration limits.

The highest hypothetical effective doee received by the maximally expoeed individual due to atmospheric releases of radioiodine from SRS was 16.3 mrem in 1956 (Table 5-7). The current annual limits on doces to members of the public recommended by the ICRP and the DOE are 500 and 100 mrem, respectively. However, a 1989 regulation established a 10 mrem/year limit on effective dose equivalents to members of the public (EPA, 1989). This value was developed to eatablish a baseline for risk aseasenent work and does not imply that a higher dose is unacoeptable. With the exception of 1956, annual doeses to offsite individuals from SRS radioiodive releases bave not exceeded 10 mrem/year.

\section{Concentrations in Groundwater}

The atandards for ${ }^{220} 1$ and ${ }^{131 !}$ in drinking water are 1 and 3 PCi/h, respectively (EPA, 1977). Sbort-lived ${ }^{231}$ I docays to immeasurably small concentrations during the migration time for contaminated groundwater to reach surface out- cropu; bowever, the inventory of ${ }^{22} I$ is not significantly depleted by decay.

In 1989 the McRean Member of the Santee Formation was found to be contaminated with ${ }^{21} I$ mear the F-Area seepage besins; the maximum concentration detected was 140 PCi $/$. At other locations on the site, the Santee Formation is a minor source of driaking water. The portion of the formation tapped for drinking water is not contaminated by 12I as evidenced by the lack of elevated tritium (Chapter 4).

The maximum I concentration obeerved for groundwater outcrops is $410 \mathrm{pCi} / \mathrm{L}$ near the F-Area seepage besin system. This value exceeds the applicable drinking water standard, but before this water resches downriver water treatment plants, it is diluted by Four Mile Creek and the Savannah River to concentrations to well below the EPA drinking water atandards.

\section{Concentrations and Doses in Offsite Surface and Potable Waters}

There are two water treatment plants downriver from SRS that use Savannah River water for domeatic and commercial service. The intake cansis for the plants are located approximately 170 kilometers below the site. The raw and finishod water supplies of the Beaufort-Jasper, SC, and Port Weatworth, GA, plants are routinely sampled for radioactivity. Concentrations of ${ }^{131}$ I at both plants are similar to the river concentrations. They have been below the limits of conventional detection since the late 1960s. Entimates of 20I concentrations determined with the computer code LADTAP II are shown in Table 5-13 for the year 1989. The value of $0.0029 \mathrm{pCi} / \mathrm{L}$ reported in the table is 0.29 percent of the EPA drinking water standard. Concentrations of ${ }^{131}$ I have not been included because after 1978 '31I was not routinely discharged to site streams that flow to the Savannah River.

No committed effective dose equivalent from SRS radioiodine releases to the Savannah River exceeds 1.2 mrem as shown in tables 5-9 and 5-10. Doeses from this exposure pathway were calculated under extremely conser- 
vative conditions and are much lower than the DOE dose standard of 4 -mrem effective dose equivalent.

It is important to note that the dose stadard of $4 \mathrm{mrem}$ is meant to be applied to all releases of rediosetivity - not just 129I and ${ }^{231}$. When the calculations are expanded to include all radionuclide releases, the relationahip betwoen SRS doeses and the various dose limits described above remains valid. The SRS, based on redioiodine or total releases, is consistently a minor contributor to radionctivity levels in the SRS environment.

Table 5-12. Comparieon of airborne ${ }^{211}$ and ${ }^{131}$ I concentrations with regulatory guidelines, $\mathrm{pCi} / \mathrm{m}^{3}$

\begin{tabular}{l|cc}
\hline \multicolumn{1}{c|}{ Parameter } & 121 & 131 \\
\hline $\begin{array}{l}\text { Derived Air } \\
\text { Concentration Guide } \\
\text { (EPA 1988) }\end{array}$ & 4,000 & 20,000 \\
$\begin{array}{l}\text { Derived } \\
\text { Concentration Guide } \\
\text { for Air (DOE 1990) }\end{array}$ & 70 & 400 \\
$\begin{array}{l}\text { Average Annual } \\
\text { Perimeter Concentration for 1989(a) }\end{array}$ & 0.000014 & 0.00000038 \\
\hline
\end{tabular}

(a) Concentrations estimated using the XOQDOQ transport and dispersion code.

Table 5-13. Comparison of estinated ${ }^{120} \mathrm{I}$ concentrations in surface waters with the regulatory guidelines, $\mathrm{PCi} / \mathrm{L}$.

\begin{tabular}{l|cc}
\hline \multicolumn{1}{c|}{ Parameter } & \multicolumn{2}{c}{ Downrfver Water Treatment Pinnt } \\
\cline { 2 - 3 } $\begin{array}{l}\text { Derived Concentration } \\
\text { Guide for Water } \\
\text { (DOE 1990) }\end{array}$ & 500 & Port Wontworth, GA \\
\hline $\begin{array}{l}\text { Drinking Water } \\
\text { Standard (EPA 1977) }\end{array}$ & 1 & 1 \\
$\begin{array}{l}\text { Average Annual } \\
\text { Concentration for 1989(0) }\end{array}$ & 0.0029 & 0.0028 \\
\hline
\end{tabular}

(a) The DOE guideline is shown solely for purposes of comparison. The $500 \mathrm{pCi} / \mathrm{L}$ limit does not apply beyond the operational boundaries of a DOE facility.

B) Concentrations estimated using the LADTAPII transport and dispersion code. 


\section{Summary of Dosimetric Impacts}

Tho overall radiological impact of SRS radioiodine releasces (1955-1989) on the offrite maximum adult can be chancterized by lotal dowes of 32 mrem (atmospheric) and 1 mrem (liquid). For the maximum individual who was a child in 1955, the total done due to atmoepheric releases is 77 mrem. For the meximum individual who was an infant in 1957 and a consumer of treated Savannah River water, the lotal doace due to aqueous releases is 3.7 mrem. However, an individual would have received a dose of approximately 12,600 mrem from other sources of ionizing radiation during 1955 . 1989.

The impact of SRS redioiodine releases on offirite population is minos. The total collective does from atmonpheric redioiodine releaces (1955-1989) is atimatod as 3,000 percon-rem dixtributed among 555,100 individunls within $80 \mathrm{~km}$ of SRS. The doce recults in a lifetime riek of $1.5 \mathrm{fatal}$ cancer cases in that population; the lifetime risk from all other causes of cancer is 90,000 fatalities. The total collective done from liquid radioiodine releases for the same period is 13 person-rem distributed among 71,000 consumens of treated Savannalh River water. The doce reaults in a lifetime risk of 0.007 fats cancer cased the lifetime risk from all other caures of cancer is 11,000 fatalitiea.

Radioiodine releases from SRS bave decreased dramatically over the counse of site operations. Measured and predicted ${ }^{21} I$ and ${ }^{131}$ I concentration data clearly reflect this tread. Based on data published in the annual environmental reports, routine '21 and ${ }^{131}$ I reloseses from SRS present a negligible risk to the offrite enviroament and the population it aupports. 


\section{References for Chapter 5}

Bair, W J., Synder, M.D, Walter, R.A, and R.F. Koough, 1963, "Effect of $1^{27}$ on Thyroid Uptake of Inhaled I131", Health Phyaics 9, 1399.

BEIR, 1990, "Health Rffects of Exposure to Low Levels of lonizing Radiation - BEIR V", Committee on the Biological Effects of lonizing Radiations, Board of Radiation Bffects Research, Commission on Life Sciences, National Research Council, National Academy of Sciences, Washington, D.C.

Cooper, R.E., 1975, “Computer Programs at SRL to Evaluate Environmental Effect of SRP Operations and Postulated Accidental Relenses", DPST-75-384, E. I. du Pont de Nemours and Company, Aiken, SC.

Cummine, C.L. D.K. Martin, and J.L. Todd, 1990, "Savannsh River Site Environmental Report for 1989", WSRC-IM-90-60, Vol. It, Westinghouse Savannah River Company, Aiken, SC, p. 96.

Cummins, C.L., D.K. Martin, and J.L.Todd, 19906, "Savannah River Site Environmental Report for 1989", WSRC-IM-90-60, Vol. I, Weatinghouse Savannah River Company, Aiken, SC, p. xv.

DOE, 1988, "Internal Dose Conversion Factors for Calculation of Dose to the Public", DOE/EH-0071, U.S. Department of Energy, Washington, D.C.

DOE, 1990, "Radiation Protection of the Public and the Bnvironment", DOE Order 5400.5, U.S. Department of Energy, Washington, D.C.

Eckerman, K.F., FJ. Congel, A.K. Roecklein, and W. J. Pasciak, 1980, "User's Guide to GASPAR Code", NUREG-0597, U.S. Nuclear Regulatory Commission, Washington, D.C.

EPA, 1977, National Interim Primary Drinking Water Regulations", EPA 5709-76-003, U.S. Environmental Protection Agency, Washington, D.C., Pga. 155 and 156.

EPA, 1988, "Limiting Values of Radionuclide Intake and Air Concentration", EPA 520/1-88-020, U.S. Environmental Protection Agency, Washington, D.C.
EPA, 1989, 40 CFR Part 61, “National Emission Standards for Hazardous Air Pollutants; Regulation of Redionuclides; Final Rule and Notice of Reconsideration", Federal Register, Vol. 54, No. 240.

ICRP, 1979, "Limits for Intake of Redionuclides by Workens", ICRP Publication 30, Part 1, Annals of the ICRP, International Commission on Radiological Protection, Pergamon Press, Oxford.

ICRP, 1989, "Age-Dependent Doses to Members of the Public from Radionuclides", ICRP Publication 56, Annals of the ICRP, Intemational Commission on Radiological Protection, Pergamon Press, Oxford.

ICRP, 1991, "Risks Aseociated with Ionizing Radiations", Annals of the ICRP 22 (1).

Marter, W.L, 1963, "Radioiodine Release Incident at the Savannah River Plant", Heaith Physics 9, 1105.

Marter, W.L., 1984, “Environmental Dosimeiry for Normal Operations at SRP", DPST-83-270, Rev. 1, E I. du Pont de Nemours and Company, Aiken, SC.

Marter, W.L., 1990, "Savannah River Site Radioiodine Releases and Offsite Maximum Doses", SRL ETS-900317, Weatinghouse Savannah River Company, Aiken, SC.

NCRP, 1987, "Recommendations on Limits for lonizing Radiation Expuaure", NCRP Report No. 91, National Council on Radiological Protection and Measurements, Bethesde, MD.

NRC, 1977a, "Methods for Estimating Atmospheric Transport and Dispersion of Gascous Effluents in Routine Releases from Light-Water-Cooled Resctors", ReguIatory Guide 1.111, Rev. 1, U.S. Nuclear Regulatory Commission, Washington, D.C.

NRC, 1977b, "Calculation of Annual Doses to Man from Routine Relesses of Resctor Effluents for the Purpose of Evaluating Compliance with 10 CFR Part 50, Appendix $I^{n}$, Regulatory Guide 1.109, Rev. 1, U.S. Nuclear Regulatory Commission, Washington, D.C. 
Sagendorf, JF, J.T. Coll, and WF. Sanducky, 1982 , XOQDOQ: Computer Progrnm for the Meteorological Evaluation of Routine Bffluent Releases at Nuclear Power Strtions", NUREG/CR-2919, U.S. Nuclear Regulatory Commisaion, Washington, D.C.

Simpeon, D.B, and B.L. McGill, 1980, “Uners Manual for LAUTAP II - A Computer Program for Calculating Rediation Exposure to Man from Routine Releases of Nucloar Reactor Effluentr", NUREG/CR-1276, ORNL/TDMC-1, Oak Ridge National Laboratory, Oak Ridge, TN.
Willard, D.H. and WJ. Bair, 1961, "Behavior of $\mathrm{I}^{311}$ Following Its Inhalation as a Vapor or as a Particle", Acta Radiologica 55, 486. 


\section{Appendix A-Physical, Chemical and Biological Properties of lodine}

The element iodine bns only one stable isotope, but numerous radionctive isotopes. Stable and radioactive isotopes of iodine show the same chemical and biological behavior. The physical properties of some of the radioactive isotopes will be described in this appendix along with the chemical and biological properties of the element iodine. A brief description of iodine in nuclear resctor socidents is also inciuded.

\section{Physical Properties}

Up to reventeen radionctive isolopes of iodine have been present at SRS due to site operation. These isotopes originate from three sources: (1) nuclear fission, (2) activation reactious (neutron capture or $(n, 20)$ reactions), or (3) commercially purchased products. Tyrically, only the longer-lived ${ }^{131}$ I and ${ }^{229}$ isotopes have boen detocted in releases to the environment în SRS facilities.

An atom of ${ }^{13}$ I docays by emitting a beta particle that belongs to one of evveral charecterietic energy groupa. The moet abundant group is emitted in 86 percent of decays. Within each energy group, the beta particles have a distribution of energies. For the mod abundant group, the maximum beta particle energy is $610 \mathrm{koV}$. Several gamme rays are also emitted in ${ }^{131}$ I decay. The moet abundant gamme ray has an energy of $364 \mathrm{keV}$ and is emitted in 82 percent of decays. The half-life of ${ }^{131}$ I atoms is 8.0 days.

The docay of ${ }^{131}$ I produces ${ }^{131} \mathrm{Xe}$ in both the ground and metastable statea. More than 99 percent of the decays of ${ }^{131}$ I produce the stable ground state ${ }^{131} \mathrm{Xe}$ without formation of the metastable state. The ${ }^{131} \mathrm{Xe}^{-m}$ that is formed decays with a 12-day half-life to the stable ground state ${ }^{231} \mathrm{Xe}$ by isomeric transition emitting a $164-\mathbf{k e V}$ gamma ray in 2 percent of the transitions.

An atom of ${ }^{221}$ decays by emitting a beta particle to form stable ${ }^{120} \mathrm{Xe}$. The emitted beta particle belongs to only one chanacteristic energy group. The maximum bets particle energy is $150 \mathrm{keV}$. Several low energy photons are also emitted. One, a gamma ray with an energy of $39.5 \mathrm{keV}$, is emitted in only 7 percent of decays. More abundant are the xenon $x$-rays which are emitted in approximately 60 percent of decaya. The $x$-rays have an energy of approximately 30 keV. The half-life of ${ }^{22} /$ atoms is 16 million years. The combination of very long half-life and low-abundance, low-energy photons make the routine detection of ${ }^{12} /$ at environmental concentrations difficult.

\section{Chemical and Biological Properties}

With oxidation atates of $-1,0,+1,+3,+5$, and +7 , iodine can exiat in numerous organic or inorganic chemical forms, some of which are volatile at ambient temperatures. The chemical and biological behavior of a specific chemical form of iodine is the same whether the iodine is stable or radionctive.

The distribution of chemical forms of radioiodine released from nuclear facilities msy differ from the distribution of chemical forms of atable iodine found in the environment. As a recult, the environmental behnvior of radioiodine and atable iodine may differ. The eavironmental behavior determines the pathway to humana. A brief deacription of the environmental behavior of iodine follows. A more thorough description can be found in the references Cohen, 1985, and Whitehead, 1984.

lodine becomes redistributed about the earth by physical and chemical proceseses in the serreatrial environment, the oceane, and the atmosphere. Much of the iodine in soil originates from the weathering of rocks. lodine can be transerred from the terrestrial environment to the atmowphere by the suspension of iodine-containing soil particles, the formation of volatile iodine compounds in vegetation and soil, and the combustion of conl.

Surface water transport of diseolved iodine and iodine-containing soil particles can redistribute iodine from the terrestrial environment to the ocenns. Iodine can be transferred from bodies of water to the atmosphere by the formation of volatile iodine compounds in the water and the formation of iodine-containing particles in spray.

Once airborne, iodine undergoes exchange between gaceous and particulate forms. In the atmoephere, gaseous iodine can exchange to the particulate form by reacting with perticulate matter. Gaseous or particulate forms of iodine can undergo decomposition resctions due to physical 
influesces anch sentipht, or chemical influences such s cosene. An arenaple of this cycle is methyl iodide which is not very reactive with particulate eurfaces. However, decomporition and exidation of methyl iodide produces demental iodine which is very reactive with perticulate entrices.

Aiborne iodine is tmeported with the wiod. Iodine is removed from the atmoephere by wet ard dry deposition. When 201 that has bees releaned to the stmocphere from 8 nuclear fuel reproceneing fecility is deponited over land, it is not readily traneported downward in the vertical soil column. This has been demonstrated by measurements of 12I near nuclear fuel reprocesaing focilities that experience different climatic and coil conditions. These facilities are SRS, Hanford, and Nuclear Fuels Services in the United States, the Kerlerube Reproceaning Plant in Germany, the Sellafield Worts in England, and the Power Resctor and Nuclear Fual Development Corporation in Japan (Anderson, 1978; Knntelo et al., 1982; Riciand et al, 1974; Braver and Strobin, 1982; Schuttellkopf and Pimpl, 1982; Robens $A$ a., 1989; Stewnt and Wilkins, 1985; Muramateu and Ohmonxo, 1986)

Deposited iodine can be removed from eoil by ramspension, surface water runoff, volatilization, and uptake into the root syctem of plents. Plants also receive iodise by direct depoaition onto leafy surfaces. Vegetntion is a step in the mijor pathway for the uptake of ${ }^{2 n I}$ by bumans who consume milk from cows that graze on vegetation contaminated with fallout redioiodine.
About 90 percent of the 0.011 gram of iodine in sdult bumne is found in the thyroid gland. lodine in the thyroid undergoes a serien of biochemical resctions to form bormones, which are important to metaboliam in moat body tissues auch as the heart, skeletal muscles, liver, and kidney. The removal of iodine from the thyroid is charecterized by the biological half-time of iodine.

\section{Properties in Nuclear Reactor Accidents}

Considerable information about the chemical properties of iodine in a nuclear renctor sccident was learned from andyeis of the Three Mile Iland scoident, which occurred in 1979. One of the eurprining aspect of the accident was the emall relense of ${ }^{131}$ I to the atmoephere. The 15 curies of ${ }^{131}$ I that wes released to the atmoephere represented leas then one part per million of the inventory of ${ }^{131} I$ in the reactor core (Voilleque, 1986). About 40 percent of the ${ }^{131}$ I is:-antory was diepered to the incide of the containment asd auxiliary buildings (Paquette of al, 1986). Mod of the iodine condensed as cesium iodide on walls, ductwort, etc.

The Chernobyl reactor sccident in 1986 alo relensed considerably leas redioiodine to the environment than wes contuined in the reactor core. As serious as this sccident was, only 20 percent of the inventory of ${ }^{11}$ I was released to the atmoesphere (USSR,1987). 


\section{References for Appendix A}

Brawer, F.P. and R.S. Strebin, Jr, 1982, "Environmental Concentration and Migration of "T", (IAEASM-257/43), in: "Environmental Migration of LongLived Radionuclides", IAEA STIPUB/597, International Atomic Energy Agency, Vienne, p. 465.

Coben, B.L, 1985, The Origin of $I$ in Soil and the ${ }^{129} 1$ Problem", Health Physics 49, 279.

Kantelo, M.V, B. Tifany, and T.J. Anderson, 1982, "lodino-129 Distritution in the Terreetrial En'vironment Surrounding a Nuclear Fuel Reproceasing Plant after 25 Yeans of Operation", (IAEA-SM-257/53P), in: "Bnvironmental Migration of Long-Lived Redionuclides", IAEA STIPUB/507, International Atomic Energy Agency, Vienne, p. 495.

Murnmatsu, Y. and Y. Ohmomo, 1986, "Iodine-129 and lodine-127 in Enviruamental Samples Collected from Tokaimura/lbaraki, Japan", The Science of the Total Environarient 48, 33.

Pequette, J., D.J. Wren, and B.L. Ford, 1986, "lowine Chemistry", in: "The Three Mile Island Accident", LM. Toth, A.P. Malinauskas, G.R. Eidam, and H.M. Burton, Edh, Symposium Serics 293, American Chemical Society, Washington, DC, p. 193.

Robens, E, J. Hauschild, and D.C. Auman, 1989, "Iodine-129 in the Environment of a Nuclear Fuel Ro- processing Plant: IV. ${ }^{201}$ and ${ }^{207}$ in Undisturbed Surface Soils", Journal of Environmental Radiosctivity 9, 17.

Schuttelkopf, H. and M. Pimpl, 1982, "Radiocoological Studies in Plutonium and lodine-129 in the Surnoundings of the Karlsrube Reprocessing Plant", (IAEASM-257/10OP), in: "Environmental Migration of Long-Lived Radionuclides", IAEA STU/PUB/597, International Atomic Energy Agency, Vienna, p. 395.

Slowart, S.P. and B.T. Wilkins, 1985, "A real distribution of w2I in Weat Cumbrian Soils", Joumal of Environmental Radioactivity 2, 175.

USSR, 1987, "Information on the Accident at the Chernobyl Nuclear Power Station and Its Consequences Propared for IAEA", Soviet Alomic Bnergy (English Tranalation) 61, 845 .

Voilleque, P.G., 1986, "Finsion Product Behavior", in: "The Three Mile Island Accident", L.M. Toth, A.P. Malinauskes, G.R. Eidam, and H.M. Burton, Eds., Symposium Series 293, American Chemical Society, Washington, DC, p. 45.

Whitebead, D.C., 1984, "The Distribution and Transformations of lodine in the Environment", Environment International 10, 321. 


\section{Appendix B-Environmental Sampling and Analysis}

Over the history of SRS, the routine environmental sampling and analysis program has evolved into a comprebensive network of sampling stations in the local environment. Similnrly, the site's capability to respond to emergency conditions has evolved to the point where mobile laboratories provide near real-time messurement results for environmental anmples. The SRS capabilities for routine and emergency monitoring of redioiodine are described in this appendix.

\section{Routine Site Operating Conditions}

The routine andycir of environmental samples such as air, min, milk, water, vegetation, wildlife, soil, and sediment hus been directed towards the detection of ${ }^{131}$ I. Detection of 12 I t the very low lovels found in the environment is technically dificult the messurement technique is not amendable to routine andyses of the magnitude of the ${ }^{131}$ sumpling progrm. However, since 1989, selected groundwater anmples have been routinely analyzed for ${ }^{120}$.

The environment is sampled by a continuous collection for a specified time, auch as a 7-day collection of water, or by an instantaneous collection, such as a grab sample of water. The reported concentration for the instantaneous sample represents the concentration at the time the sample was collected; the concentration at messurement time is corrected for radioactive decay during the time between sumple collection and enmple measurement. For the continuous collection, the mensured concentration is corrected for ndiosctive decay during the elapaed time since either the start or the midpoint of the collection; one or the other correction has been ueed during the history of SRS.

\section{Air}

Atmospheric sampling locations near the site perimeter increased from 8 in 1955 to 14 in 1989. Correspondingly, at the 40-km radius, sampling locations increased from 3 to 12. Figure B-1 shows the locations within the $40-\mathrm{km}$ radius.

Locations at greater distances were added in 1962 to belp distinguish SRS-released radioiodine from that due to fallout, which was more generally distributed in the environment. Four locations (Columbis, SC, Greenville, SC, Macon, GA, and Savannah, GA) were added at the $160-\mathrm{km}$ radius to aid this efex:

The air samplers for radioiodine continuously pass a filtered air atream through a cartridge of activated charcoal impreganted to 5 percent triethylenediamine (TEDA). The charcad cartridge and particulate filter are changed weekly and analyzed by gamm spectrometry. (The sampling material ued until the mid 19603 was a filter paper conted with silver nitrate.)

Rain

Some of the locations for air monitoring also have the capability to collect rainwater. Rainwater collects in atainleas acel pans $60 \mathrm{~cm}$ by $60 \mathrm{~cm}$ and flows through an anion-cation exchange column beneath the pan and then into a collection bottle for volume mensurement. The ion exchunge column iv changed every fourth week except at the $160 \mathrm{~km}$ location, where it is changed quarterly. The ion exchange columns are andyzed by gnmm epectrometry.

Because the minwater collection pans are continually exposed to the atmosphere, they alno collect dry deposition. Rainwater en leach radioiodine from the dry deposition; this redioiodine is trapped on the ion exchange column.
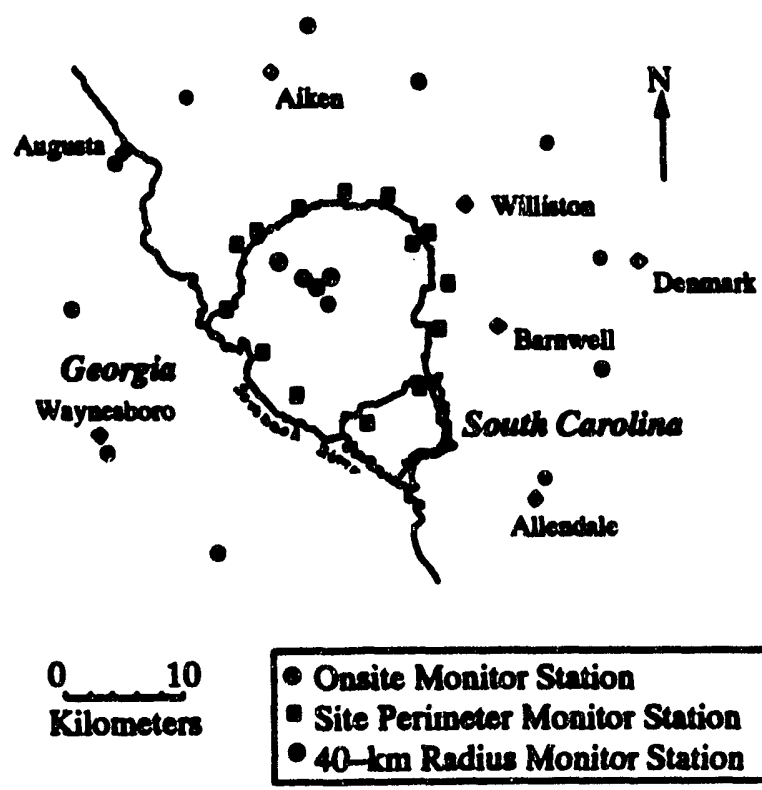

Fogre B-1. Air Monitoring Locations within $40 \mathrm{~km}$ of SRS 


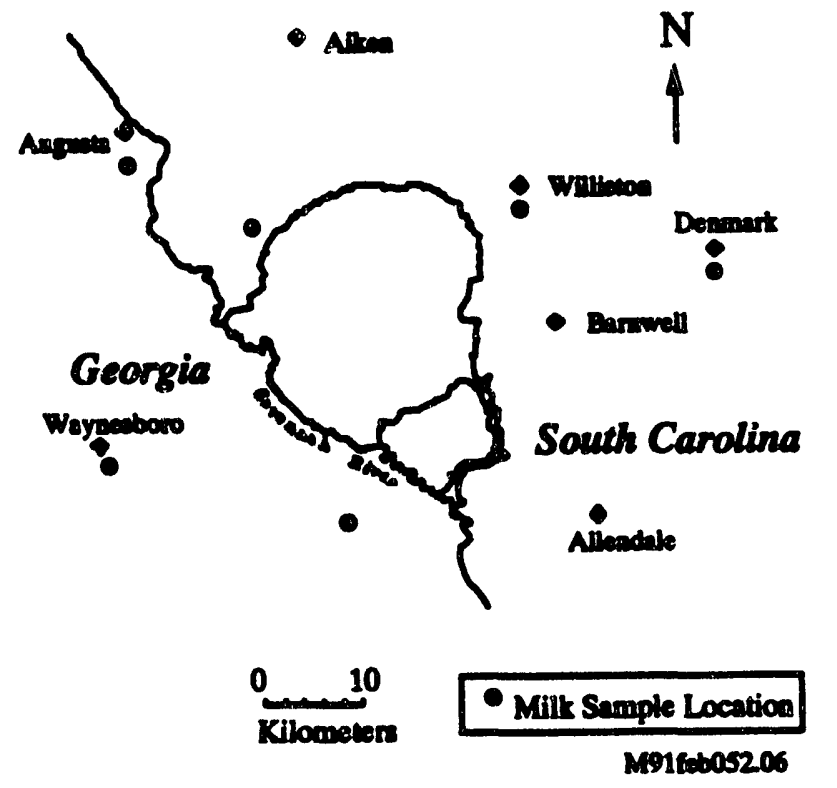

Digure B-2. Milk Monitoring Locations within $40 \mathrm{~km}$ of SRS

Milk

Milk sumples are collected every two weeks from approximately five dairies and one major distributor within the 40-km radius of SRS. The locations of the dairies sampled in 1989 are shown in Figure B-2. The dairy in Williston, SC, censed operution in 1989. Its replecement for ampling purposes is a dairy in Denmark, SC. During the history of the site, various dairies and farms out to $80 \mathrm{~km}$ have been sampled.

Four liters of milk are pased through an anion exchange column. The ion exchange column is analyzed by gamma spectrometry.

\section{Groundwater}

Routine monitoring of SRS wells for ${ }^{111}$ I began in 1956. In 1989 approximately 140 wells were sampled for ${ }^{131}$ once during the year. Samples are collectod either by pumping or beiling the welle. A 1-liter aliquot is analyzed by gamma spectrometry.

The routine andyeis for 201 in groundwater samples began in 1989. Jodine in quarterly amples is chemically separated, purified, and analyzed by low-energy photon spectrometry.

\section{Surface Water}

Sampled surface waten coneist of procese area effluent outfalle, site treams, and the Savannah River. Sinpling locations are shown in Figure B-3. A grealer number of sampling locations exist at outfalls from process areas than can be shown on this figure.

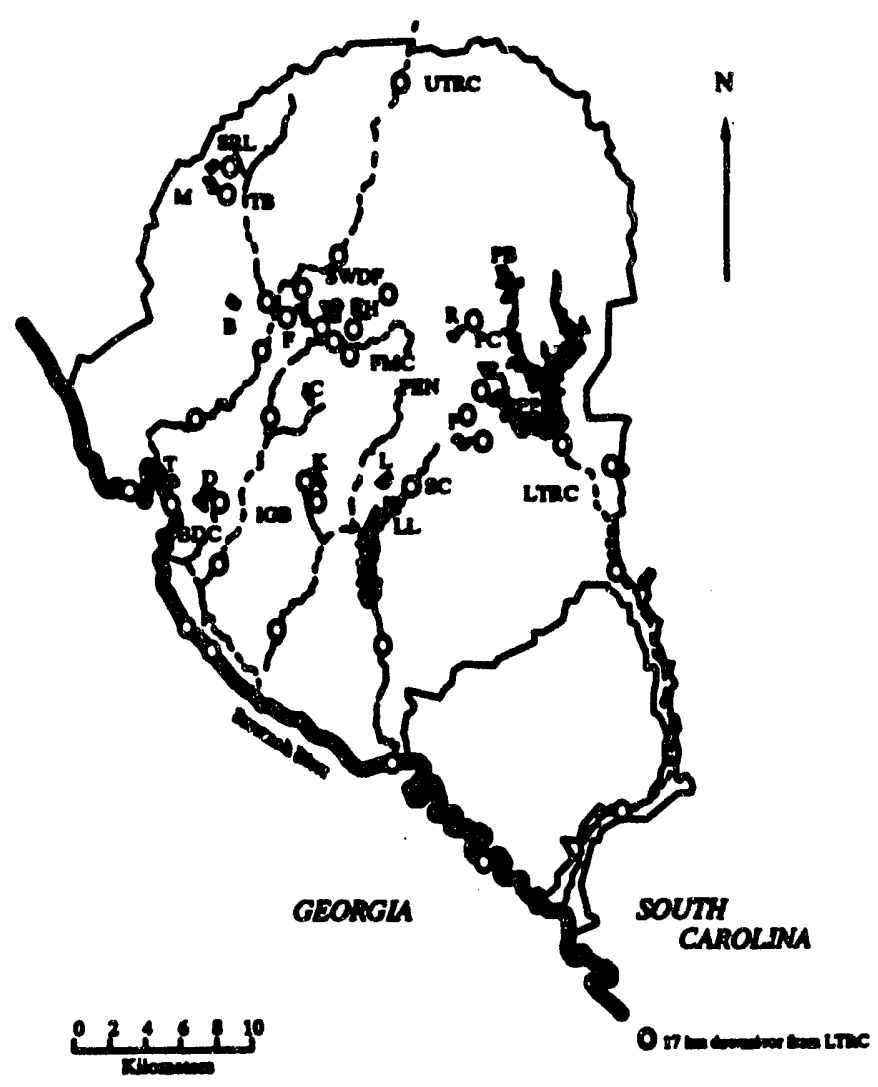

Pocthine Lexid

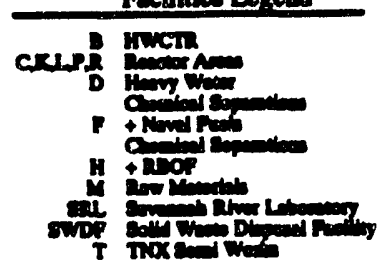

Surfec Waren Lerand

Dempont

Per

con 0

II. itin

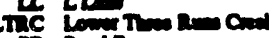

ic

in mand

$\boldsymbol{P}$ rom

ce com

is $T^{2}=$ o mintom

Figure B-3. Surface Water Sampling Locations Onsite and Offaite 
Efiluent ontinll from process aress

Samples are generally collected from the ditch or canal connecting the process outfill with a body of wrface water. Various composite amplers are used, the principal ones being the paddle whoel sampler and the Brailsford pump sampler.

Routine water amples are retrieved weekly. A 1-liter aliquot is andyzed by gamma spectrometry.

\section{Slte Strenms}

Samplers are similar to those described for effluent outfalls. Routine water amplers are retrieved weekly, and a 1-liter aliquot is analyzed by gamma spectrometry.

\section{Savannah Rfver}

The Savannah River has been ampled at the locations shown in Figure B-3. Water samples are collected by a paddle wheel sampler which provides a continuous sample. Samples are retrieved weekly, and a grab sample is also collected at the upriver sampling location.

Initially, iodine was chemically separated from the water by solvent extraction. This process was changed in 1963 to passing water through an anion-cation exchange column. The ion exchange column is analyzed by gamma spectrometry.

\section{Other Environmental Media}

Periodic samples of vegetation, wildlife, soil, sediment, and food other than milk are collected for radiosctivity measurement.

\section{Emergency Response Conditions}

Site resources aveilable for emergency response to unplanned relesses of radionctivity include the SRS Operations Center, the Weather Information and Display System (WIND), two mobile laboratories, and field sample collection teams. The SRS Operations Center is the command center for coordination of the site's response to emergency conditions.
Weather Information and Display System

Material releasod from SRS to the atmosphere moves through the atmosphere as a plume. The WIND System is a computerized emergency response system that predicts the location of the plume as a function of time after an unplanned release. It also predicts concentrations of specific isotopes in the plume and the doae coneequences of the release. The WIND System is linked to the Weather Center Analysis Laboratory in SRL and to the SRS Operations Center.

The WIND system uses a variety of real-time environmental deta as input to its metcorological transport and dispercion computer codes. The inputs include meteorological deta from seven instrumented towers onsite and one tower offsite, stack monitoring data, and perimeter monitoring data.

Prodicted concentrations and does from an unplanned release provide a preliminary assessment of the consequences to public health in the path of the plume. This information is communicated to the SRS Operations Center. WIND predictions are aleo used to position the site's field resources for emergency response - the two mobile laboratories and the sample collection teams at ideal locations for sample collection.

\section{Radiological Assistance Program Laboratory}

The Radiological Assistance Program mobile laboratory became operational in 1986 to provide near real-time assesement of any radiological emergency in the southeastern statea. It has numerous capabilities for this purpose, but only those capabilities applicable to a radioiodine release will be described here.

Grab samples of soil, water, milk, vegetation, and air can be collected. The air amples are obtained with portable sampling kits that pump air through silver zeolite cartridges. The on-board measurement instrumentation used to assess these environmental samples for isotopes of iodine include sodium iodide and germanium detoctors for gamma spectrometric analyais. However, ${ }^{12} /$ is not detectable by this tochnique. In the case of a radiological emergency at SRS, results of gamma spectrometric analyses performed in the field are communicated to the SRS Operations Center. 


\section{Tracking Radioactive Atmospheric Contaminants Laboratory}

The Tracking Rediosctive Atmospheric Contaminants (TRAC) mobile imborntory became operational in 1984. It was principally decipned to aseese the rediological impact on the generd public of an atmoepheric release from SRS. It has the capability to continuously monitor the environment for redionuclides in real-time and to perform specialized analyees on-bound in near real-time. Only those capabilities applicable to a radioiodine release will be described here.

As a plume of material released from SRS moves through the atmoephese, the location of the plume can be continuously monitored by TRAC using scintillation apectrometers provided the plume contrins gamma-amitting nuclides, such $2{ }^{211}$. This monitoring can occur while TRAC is parked or moving. Recults of these real-time analyses to locate the plume and to monitor its movemeat are communicated to the Weather Center Analyais Laboratory where the information is used to refine WIND predictions.

To determine the atmospheric concentrations of radioiodine, amples of air are obtrined with an on-board high volume sampler that pumpe air at $25 \mathrm{~m}^{3}$ per minute. Airborne particulate forms of iodine are trapped on a high efficiency particulate air (HEPA) filter. Volatile forms of iodine are trapped on a TEDA-impregnated charcoal filter. To maximize the abeorption of iodine on the charconl, only a portion of the HEPA-filtered air is pased through the charcosl. This flow rete is limited to $1 \mathrm{~m}^{3}$ per minute. This ampling can occur while TRAC is parked or moving.

The on-bonerd measurement instrumentation used to seany air sampies for radioiodine include high resolution germa- nium dotectors for onmm spectrometric analysis (2M is not detectable by this techniquo). Typically, within 30 minutes of commencing eample collection, radioiodine concentration reaults are available for communication to the Weather Center Analyeis Loboratory. These near real-time revults provide measured concentratione to compare with computer-predicted concentrations. Interpretations of the results in terms of dose assessment are then communicated from the Weather Center Analyais Laboratory to the SRS Operations Center.

In addition to monitoring the atmosphere, TRAC has the capability to monitor the road for deposited radioiodine. This real-time analyais is done with another set of scintillation spectrometern. Environmental samples wach as soil, water, millk, and vegetation can be collected in the field and analyzed for their radioiodine content using the on-board high resolution germanium detectors. Rewults of these additional ansalyes are communicated to the Weather Center Analyais Laboratory as they become available.

\section{Field Sample Collection Teams}

Sample collection teams are deployed to appropriate locations in the field to collect a variety of eavironmental samplea. The asmples are returned to ewvironesental laboratories af SRS for subeequent analyain. Theee environmental sumples provide greater comprebensive coverage of the consequences of a release than the coverage provided by the mobile laboratoriea. However, the availability of ana. lytical recults is not near real-time. Examples of this type of ample collection and analyais were presented in Chapter 4 where the 1961 scute ${ }^{131}$ I release incident was discussed. 


\section{Bibliography}

L. Information presented in this report is compiled from the following internal documents or from other sources that are referenced separately in the text.

A. Compilation of the history of radionative releness:

DPSPU-86-25-1 "Reloases of Radioactivity at the Savannah River Plant"

WSRC-RP-91-684 "Radioactive Releases at the Savannah River Site 1954-1989"

B. Reports on the entire environmental monitoring program at SRS. Report titles repeat in wecoeding years until revised.

\begin{tabular}{ll} 
DP 92 & Jan-Jun 1954 \\
DPSP 55-25-34 & "Radioactivity in the Environs of the Savannah River Plant" \\
DPSP 56-25-13 & "Semi-Annual Progreas Report-Regional Monitoring" \\
DPSP 56-25-54 (DEL) & Jul-Dec 1955 \\
DPSP 56-25-4 (DEL) & Jan-Jun 1956 \\
DPSP 57-25-15 (DEL) & Jul-Dec 1956 \\
DPSP 57-25-43 (DEL) & Jan-Jun 1957 \\
DPSP 58-25-17 (DEL) & Jul-Dec 1957 \\
DPSP 58-25-38 (DEL) & Jan-Jun 1958 \\
DPSPU 59-11-23 & Jul-Dec 1958 \\
DPSPU 59-11-30 & Jan-Jun 1959 \\
DPSPU 60-11-9 & Jul-Dec 1959 \\
DPSP 60-25-26 (DEL) & Jan-Jun 1960 \\
DPSP 61-25-4 (DEL) & Jul-Dec 1960 \\
DPSP 62-25-2 (DEL) & Jan-Jun 1961 \\
DPSP 62-25-9 (DEL) & Jul-Dec 1961 \\
DPSP 63-25-3 (DEL) & Jan-Jun 1962 \\
DPSP 63-25-10 (DEL) & Jul-Dec 1962 \\
DPSPU 64-11-12 & Jan-Dec 1963 \\
DPST 65-302 & Jan-Dec 1964 \\
DPST 66-302 & Jan-Dec 1965 \\
DPST 67-302 & Jan-Dec 1966 \\
DPST 68-302 & Jan-Doc 1967 \\
DPST 69-302 & Jan-Dec 1968 \\
DPST 70-302 & Jan-Dec 1969 \\
DPST 71-302 & Jan-Dec 1970 \\
DPSPU 72-302 & Jan-Dec 1971 \\
DPSPU-73-302 & Jan-Dec 1972 \\
DPSPU 74-30R & Jan-Dec 1973 \\
DPSPU 75-30R & Jan-Dec 1974 \\
\hline
\end{tabular}




$\begin{array}{ll}\text { DPSPU 76-302 } & \text { Jan-Dec } 1975 \\ \text { DPSPU 77-302 } & \text { Jan-Dec } 1976 \\ \text { DPSPU 78-302 } & \text { Jan-Dec } 1977 \\ \text { DPSPU 79-302 } & \text { Jan-Dec } 1978 \\ \text { DPSPU 80-302 } & \text { Jan-Dec } 1979 \\ \text { DPSPU 81-302 } & \text { Jan-Dec } 1980 \\ \text { DPSPU 82-302 } & \text { Jan-Dec } 1981 \\ \text { DPSPU 83-302 } & \text { Jan-Dec } 1982 \\ \text { DPSPU 84-302 } & \text { Jan-Dec } 1983 \\ \text { DPSPU 85-302 } & \text { Jan-Dec } 1984 \\ \text { DPSPU 86-30-1 } & \text { Jan-Dec } 1985 \\ \text { DPSPU 87-30-1 } & \text { Jan-Dec } 1986 \\ \text { DPSPU 88-30-1 } & \text { Jan-Dec } 1987 \\ \text { WSRC-RP-89-59-1 } & \text { Jan-Dec } 1988 \\ \text { WSRC-IM-90-60 } & \text { Jan-Dec } 1989 \\ \text { (DEL) gignifies reiene of report from which claneified information was deleted. }\end{array}$

C. Reports on the environmental monitoring program that involved principally the offisite environment. Report titles repeat in succeeding years until revised.

\begin{tabular}{ll} 
DPSPU 62-30-11 & Oct-Dec 1961 \\
\hline DPSPU 62-30-24 & Jan-Jun 1962 \\
DPSPU 63-30-12 & Jul-Dec 1962 \\
DPSPU 63-30-32 & Jan-Jun 1963 \\
DPSPU 64-30-1 & Jul-Dec 1963 \\
DPSPU 64-30-2 & Jan-Jun 1964 \\
DPSPU 65-30-1 & Jul-Dec 1964 \\
DPST 65-30-2 & Jan-Jun 1965 \\
DPST 66-30-1 & Jul-Dec 1965 \\
DPST 66-30-2 & Jan-Jun 1966 \\
DPST 67-30-1 & Jul-Dec 1966 \\
DPST 67-30-2 & Jan-Jun 1967 \\
DPST 68-30-1 & Jul-Dec 1967 \\
DPST 68-30-2 & Jan-Jun 1968 \\
DPST 69-30-1 & Jul-Dec 1968 \\
DPST 69-30-2 & Jan-Jun 1969 \\
DPST 70-30-1 & Jul-Dec 1969 \\
DPST 70-30-2 & Jan-Jun 1970 \\
DPST 71-30-1 & Jul-Dec 1970
\end{tabular}

The Effect of the Savanuah River Plant on Environmental Radioactivity" 


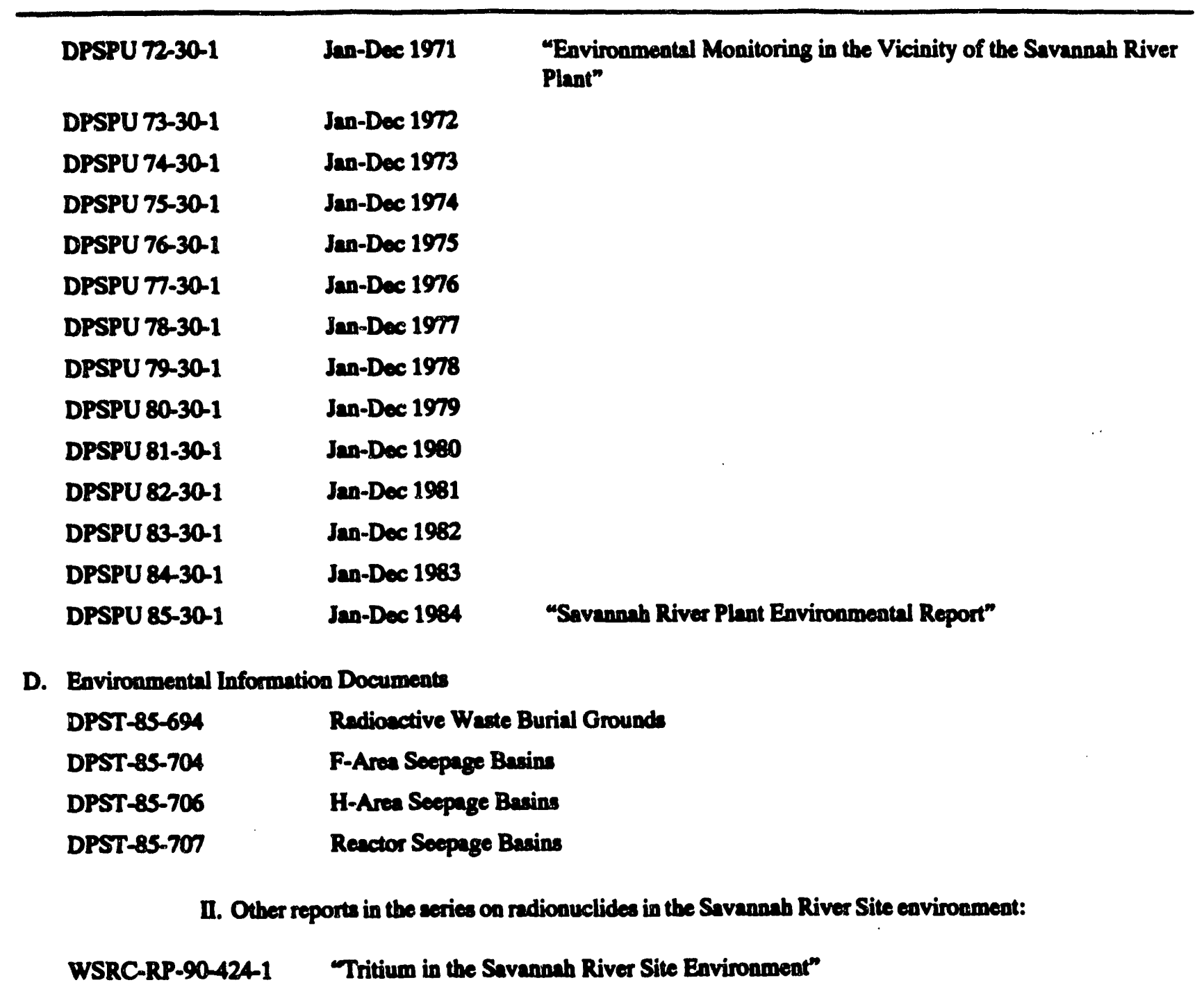




$$
\longrightarrow
$$

iv samosense 

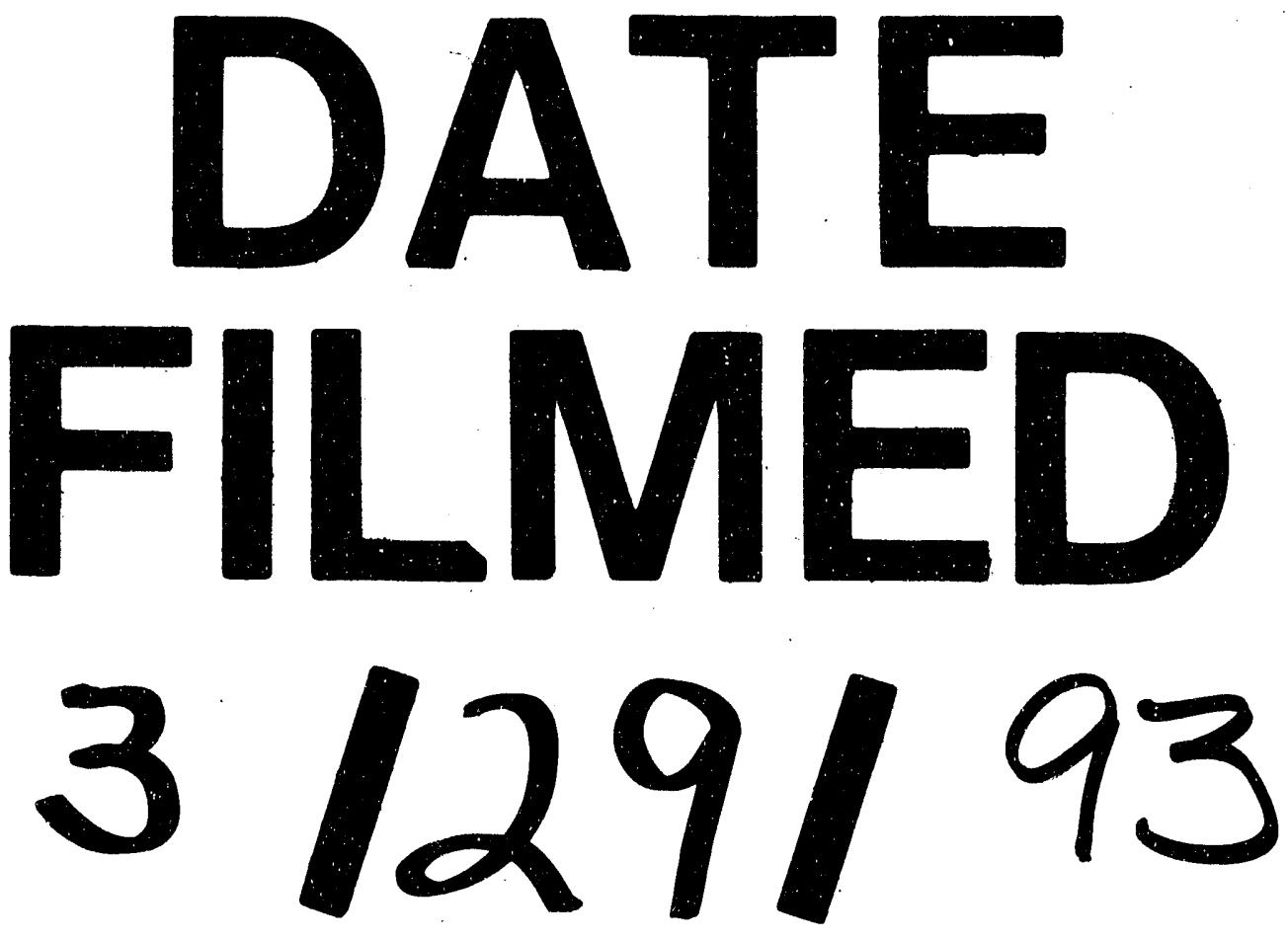
